\title{
Mauritius: Selected Issues and Statistical Appendix
}

This Selected Issues paper and Statistical Appendix for Mauritius was prepared by a staff team of the International Monetary Fund as background documentation for the periodic consultation with the member country. It is based on the information available at the time it was completed on July 8, 2004. The views expressed in this document are those of the staff team and do not necessarily reflect the views of the government of Mauritius or the Executive Board of the IMF.

The policy of publication of staff reports and other documents by the IMF allows for the deletion of market-sensitive information.

To assist the IMF in evaluating the publication policy, reader comments are invited and may be sent by e-mail to publicationpolicy@imf.org.

Copies of this report are available to the public from

International Monetary Fund $\bullet$ Publication Services

700 19th Street, N.W. • Washington, D.C. 20431

Telephone: (202) 6237430 • Telefax: (202) 6237201

E-mail: publications@imf.org • Internet: http://www.imf.org

Price: $\$ 15.00$ a copy

\section{International Monetary Fund Washington, D.C.}





\title{
INTERNATIONAL MONETARY FUND
}

\author{
MAURITIUS \\ Selected Issues and Statistical Appendix \\ Prepared by a staff team consisting of Calvin McDonald (head), \\ James Y. Yao, Jung Yeon Kim, Marwan Mikhael (all AFR), \\ and Nathan Porter (FIN) \\ Approved by the African Department
}

July 8, 2004

Contents

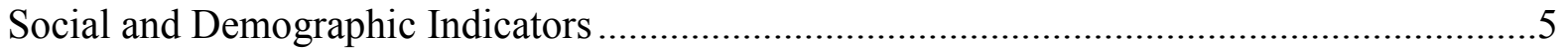

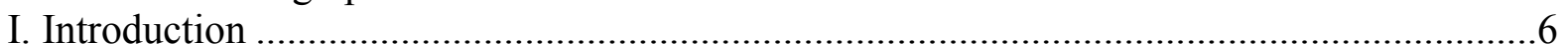

II. Impact of the Erosion of Trade Preferences on Exports, Growth, and Employment in

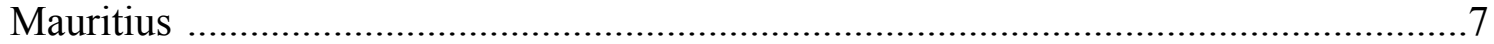

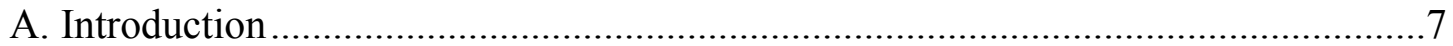

B. Exports, Growth, and the Labor Market .........................................................

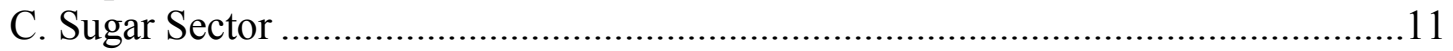

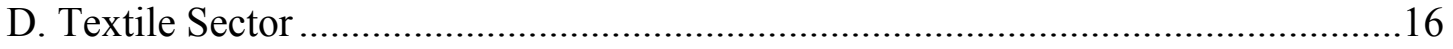

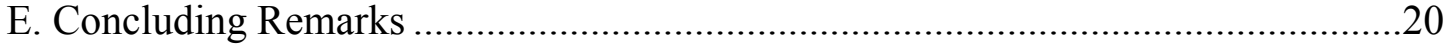

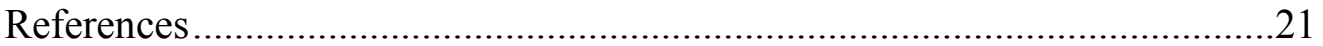

III. Mauritian Labor Market Institutions and Low-Skill Employment .................................23

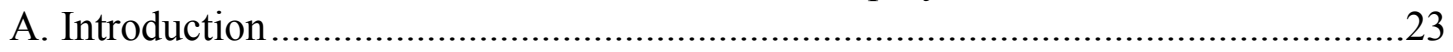

B. Evolution of Employment in the EPZ (Textiles) Sector .....................................25

C. An Assessment of the Impact of Wage Setting and Redeployment Restrictions....27

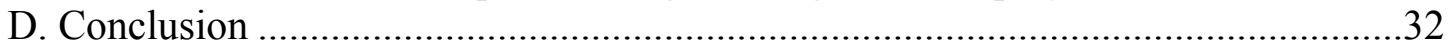

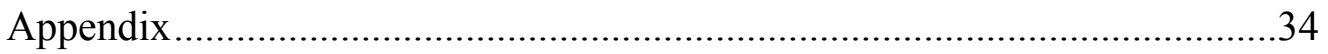

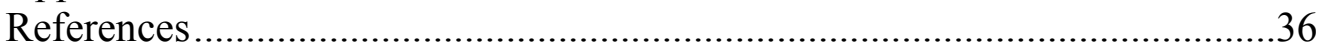

IV. Inflation Targeting in Small Open Economies: The Case of Mauritius ..........................38

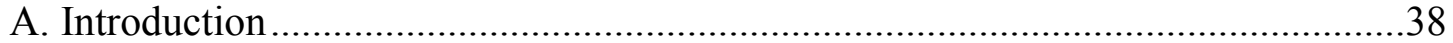

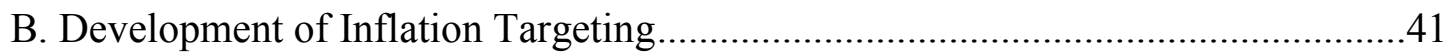

C. An Open Economy Macrofinance Model .............................................................46

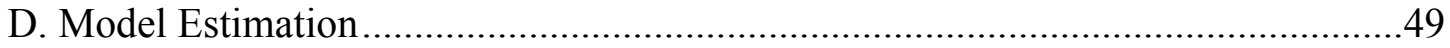

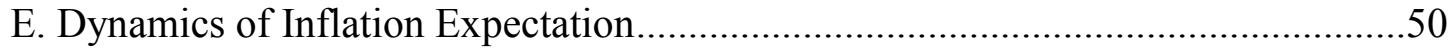

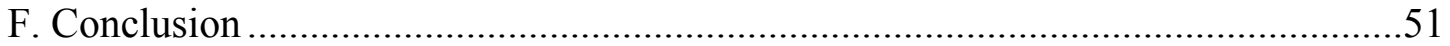

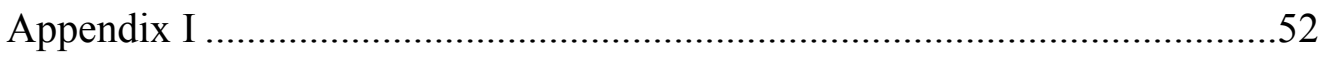

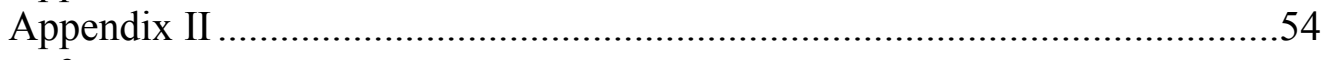

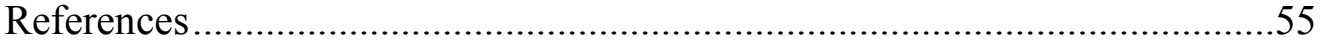


V. Developing a Corporate Bond Market in Mauritius: Some Lessons from Emerging Market

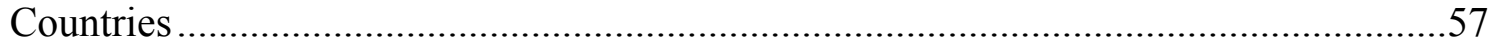

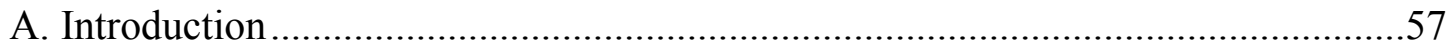

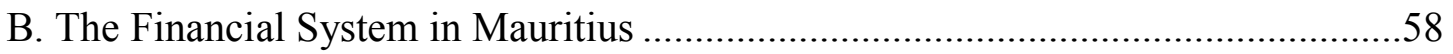

C. Benefits of an Efficient Corporate Bond Market ................................................67

D. Factors Contributing to the Successful Development of a Corporate Bond

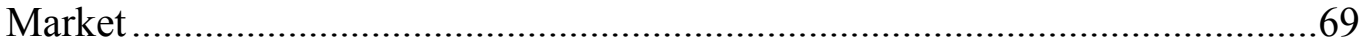

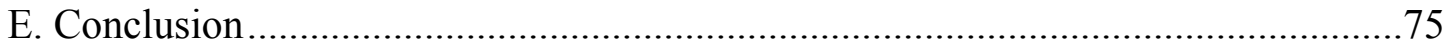

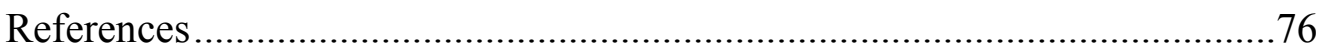

Figures

II.1 Evolution of Exports and GDP in Mauritius....................................................

II.2 Labor Costs and Labor Productivity in Mauritius ................................................. 10

II.3 Ratio of Sugar Exports to Total Exports of Goods .............................................13

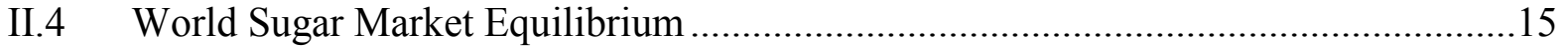

II.5 Ratio of EPZ Exports to Total Exports of Goods ..................................................18

III.1 Decomposition of Annual EPZ Employment Growth, 1982-2002 ...........................27

III.2 Annual EPZ Employment Growth and Reallocation Rates, 1983-2002 ....................27

III.3 Decomposition of Quarterly EPZ Employment Growth, 1986-2003 .......................27

III.4 Average Size of New and Closing Firms, 1986-2002 …....................................27

III.5 The Impact of Labor Market Institutions..............................................................29

III.6 Cross-Market Wage Compression: Unemployment and Job Destruction ...................33

III.7 Within-Market Wage Compression: Unemployment and Job Destruction .................33

III.8 Worker Redeployment: Unemployment and Job Destruction ..................................33

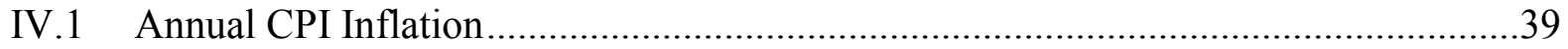

IV.2 Nominal and Real Effective Exchange Rates ......................................................45

IV.3 The Level and Slope of the Yield Curve .............................................................51

V.1 Mauritian Onshore Banks: Sectoral Credit Distribution (as of February 2004).........61

V.2 Nonperforming Loan Ratios Per Sector (as of December 31, 2003) .......................62

V.3 Differential between Average Bank Lending Rate and Average T-bill Rate ..............69

\section{Text Tables}

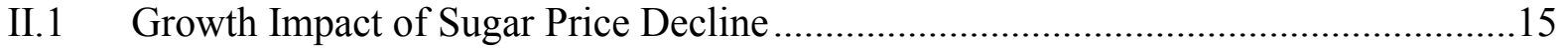

II.2 Growth Impact of Moderate Textile Shock ..........................................................19

II.3 Growth Impact of Severe Textile Shock ...........................................................20

II.4 Growth Impact of Combined Sugar and Textile Shocks ......................................20

III.1 Quarterly Job Flows Rates ..............................................................................28

III.2 Model Output: The Impact of Labor Market Restrictions .......................................31

IV.1 CPI Inflation Targets and Outcomes............................................................42

IV.2 Bank of Mauritius Foreign Exchange Market Intervention, 1996/97-2003/04 ..........44

V.1 Financial System Structure (at the end of June 2002) .........................................59

V.2 Summarized Aggregate Balance Sheet of Category 1 Banks as of February 29, 2004 
V.3 Sectoral Growth of Credit to Private Sector ....................................................63

V.4 Summary Aggregate Balance Sheet of Category 2 Banks, as of February 29, 2004 ..64

V.5 Assets of Contractual Savings Institutions, 2001-02 ….......................................65

V.6 Asset Allocation of Contractual Savings, 2000-02 .............................................65

Statistical Appendix Tables

1. GDP Real Growth Rates by Industrial Origin, 1999-2003 ......................................78

2. GDP at Current Prices by Industrial Origin, 1999-2003 ...........................................79

3. Real Growth Rates of Expenditure on GDP, 1999-2003 ..........................................80

4. Expenditure on GDP at Current Prices, 1999-2003 …...........................................81

5 Real Growth Rates of Gross Domestic Fixed Capital Formation, 1999-2003 ..............82

6. Composition of Gross Domestic Fixed Capital Formation

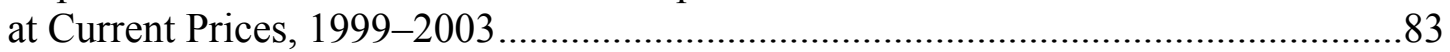

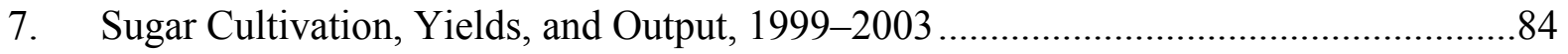

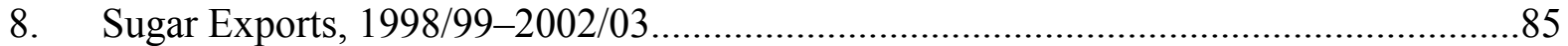

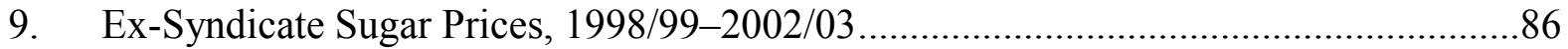

10. Revenue and Expenditure of Sugar Estates with Factories, 1999-2003 ......................87

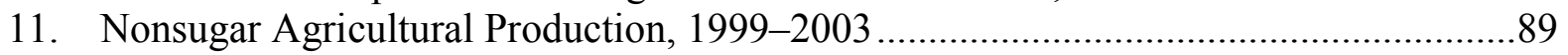

12. Export Processing Zone (EPZ) Activity, 1999-2003 .............................................90

13. Electricity Production and Consumption, 1999-2003 _..........................................91

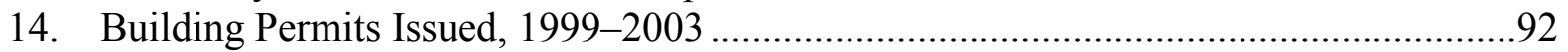

15. Tourist Arrivals, Capacity, and Earnings, 1999-2003 ...............................................93

16. Estimated Labor Force and Employment, 1999-2003 ….........................................94

17. Average Earnings by Sector-Monthly Paid Employees, 1999-2003 ........................96

18. Labor Costs and Productivity in Manufacturing, 1999-2003 …................................97

19. Cost Structure and Prices of Petroleum Products, 1998/99-2002/03 ............................98

20. Consumer Price Indices by Major Commodity Groups,

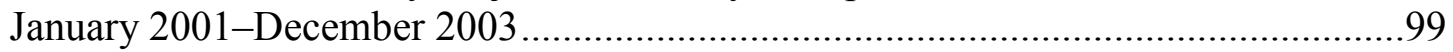

21. Summary of Government Finances, 1998/99-2002/03 ..........................................100

22. Revenue and Grants, Budgetary Central Government, 1998/99-2002/03 .................101

23. Functional Classification of Expenditure and Net Lending, Consolidated Central Government, 1998/99-2002/03 ...............................................................102

24. Transfers and Subsidies by Budgetary Central Government, 1998/99-2002/03 .........103

25. Income and Expenditure of the National Pension Fund, 1998/99-2002/03 _...............104

26. State Trading Corporation-Ration Rice and Flour Transactions, 1998/99-2002/03

27. Financing of Central Government Deficit, 1998/99-2002/03 ..................................106

28. Government Domestic Nonbank Debt Outstanding by Holder, 1998/99-2002/03 ......107

29. External Debt of Central Government - Disbursements, 1998/99-2002/03 _..............108

30. Consolidated Monetary Survey, June 1999-December 2003 ..................................110

31. Summary Accounts of the Bank of Mauritius, June 1999-December 2003................111

32. Summary Accounts of Commercial Banks, June 1999-December 2003 ...................112

33. Consolidated Assets and Liabilities of Category 2 Banks: 1999-2003 .......................113

34. Principal Interest Rates, 1999-2003 ..................................................................114 
35. Balance of Payments, 1998/99-2002/03 …..........................................................115

36. Principal Merchandise Trade, Price Indices, and Terms of Trade, 1999-2003 ...........116

37. Pattern of Trade and Direction of Exports of the Export Processing

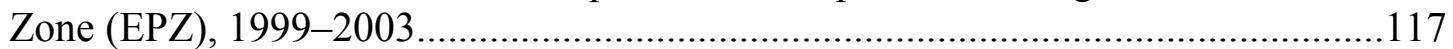

38. Medium- and Long-Term External Debt, June 1999-December 2003 ......................118

39. External Debt-Service Payments, 1998/99-2002/03 …........................................119

40. Effective Exchange Rate Indices, January 1990-March 2004 ................................120

41. Summary of the Tax System as of February 29, 2004 ...........................................121 


\section{Mauritius: Social and Demographic Indicators ${ }^{1}$}

Population

Population (thousands; 2002)

Annual rate of growth (percent; annual)

Population under age 15 (percent; 1999)

Density (per square km.; 1999)

Land area (square km.)

Population characteristics

Life expectancy at birth (years; 2002)

Male

Female

Infant mortality (per thousand; 2001)

Crude birth rate (per thousand; 1999)

Crude death rate (per thousand; 1999)

Fertility rate (births per woman; 2001)

Labor force

Total (thousands, including foreigners; 2003) Of which: female (percent; 2003)

Annual growth rate (percent; average 1998-2003)

Sugar workers (percent of total employment; 2003)

Export processing zone workers (percent of total employment; 2003)
Education

Adult illiteracy rate (percent; 1995) 15

Female 19

Male 12

Gross primary school enrollment

(percent; 2001) 2/ 93.2

Gross secondary school enrollment

(percent; 2000) 2/

Income

GDP per capita (U.S. dollars; 2002/2002) 3/ 4,352

Poverty

Population below $\$ 1$ a day

Health

Health care access (percent of population; 1991)

Immunization for measles (percent of population less than 12 months; 1995)

Population per physician (1999)

Population per hospital bed (1999)

Safe water access (percent of population; 1993) 100

Sources: Central Statistical Office; IMF, International Financial Statistics; World Bank, World Development Indicators database; and World Bank, Country Assistance Strategy of the World Bank Group for the Republic of Mauritius, 1997.

1/ The Republic of Mauritius consists of the islands of Mauritius and Rodrigues, and two very small "outer" islands. Population density varies greatly among these.

2/ Gross enrollment ratio is the ratio of total enrollment, regardless of age, to the population of the age group that officially corresponds to the level of education shown.

3/ Fiscal year July to June constant 1995 US\$. 


\section{INTRODUCTION}

1. This collection of selected issues papers provides background information and analytical support for key policy issues discussed in the 2004 Article IV consultation discussions with Mauritius. The Article IV consultation report identifies three immediate and medium-term challenges facing Mauritius, namely, the need to adapt the economy to the impending loss of trade preferences in sugar and textiles, the urgency of carrying out structural reforms to lessen labor market rigidities and the requirement to reduce fiscal deficits over the medium term to ensure fiscal sustainability and macroeconomic stability. Regarding the latter, the staff report for the consultation discussions contains a detailed appendix on the medium-term path toward public debt sustainability. The consultations also assessed the monetary policy framework in Mauritius and identified further structural reforms that should be pursued in order to strengthen the financial system.

2. In the first of the four papers, the impact of the erosion of trade preferences on exports, growth, and employment is assessed under two scenarios - a moderate and an extreme scenario. To quantify the adverse impact of trade liberalization, the paper estimates various elasticities of GDP growth to exports, and unemployment to growth. The analysis finds that in the worst case scenario, medium-term growth could be up to 50 percent below the staff's baseline projections of 4 percent annual growth.

3. The paper on labor market institutions and low-skilled employment uses a simple stylized model of the job creation and destruction process to assess the potential benefits of labor market reform. The conclusion is that even relatively minor wage compression and restrictions on the redeployment of workers can have a dramatic impact on the fragility of jobs and the extent of unemployment and labor-market churning.

4. Mauritius has achieved success in its informal inflation targeting framework. By combining a standard macro-finance model with an open economy model, an empirical assessment is made of the critical channels through which the central bank has been able to implement credible monetary policies. The empirical results indicate that the informal inflation targeting framework (by targeting inflationary expectations) has been able to provide a strong nominal anchor even in the context of a managed float exchange rate system.

5. Finally, the last paper discusses the institutional requirements for developing a corporate bond market in Mauritius. Credit concentration in the banking sector is a major concern in Mauritius. Development of an efficient bond market would not only provide alternative investment opportunities for institutional investors, but would also spread credit risk in the economy. Successful development of an active bond market will require a deepening of the market for government debt, a strengthening of the legal and credit risk infrastructure and a broadening of the investor and issuer base. 


\section{Impact of the Erosion of Trade Preferences on Exports, Growth, AND EMPLOYMENT IN MAURITIUS ${ }^{1}$}

\section{A. Introduction}

6. Mauritius faces significant challenges in the sugar and textile sectors in an increasingly competitive global environment. Increased trade liberalization is expected to have a positive impact on international trade and growth in the long run, but could have adverse effects on Mauritius in the short run. In particular, Mauritius will have to cope with the decision of the WTO regarding the liberalization of the sugar sector and with the phasing out of the textile quotas with the expiration of the WTO Agreement on Textiles and Clothing (ATC) in January 2005. In addition, Mauritius does not qualify for the third country fabric under the U.S. African Growth and Opportunity Act (AGOA) II. These developments could lead to a temporary deterioration in Mauritius's current account balance.

7. In the past three decades, Mauritius showed the ability to cope with challenges and registered impressive growth rates. Growth rates of the economy averaged around 6 percent and the exports ${ }^{2}$ to GDP ratio currently hovers around 40 percent, which puts Mauritius at the forefront of export-oriented economies. Three decades ago, Mauritius mainly relied on the sugar sector for its exports earnings. The economy subsequently diversified to include tourism and textile manufacturing in the export processing zone (EPZ). In light of the current challenges, the authorities now aim to develop the economy into a hub for the technology and financial services sectors.

\section{In the medium term, the baseline growth projection in the Article IV}

consultation report is 4 percent per annum. This baseline scenario assumes a weak performance in both the sugar sector and the export processing zone (EPZ), reflecting increased global competition, a reduction in the area used for sugarcane production, and a gradual disinvestment of some foreign textile companies. These developments are expected to be balanced by the economy's partial adjustment to the changing international business environment through the restructuring of the economy and the development of other sources of growth, including the Information and Communications Technology (ICT) and financial services sectors.

9. The rest of the paper is organized as follows: Section B analyzes the relationship among exports, economic growth, and the labor market in Mauritius in order to derive elasticities that are used to estimate the effects of negative shocks in subsequent sections. Section $\mathrm{C}$ examines the current situation in the sugar sector and the likely impact of trade liberalization. Section D discusses the textile sector and the possible impact of the phasing out of textile quotas in international trade on growth and employment. The impact of combined shocks to the sugar and textile sectors are also considered. Section E provides concluding remarks.

${ }^{1}$ Prepared by Marwan Mikhael.

${ }^{2}$ Exports of goods. 


\section{B. Exports, Growth, and the Labor Market}

10. The literature has extensively examined the relationship between exports and economic growth. Since exports are part of GDP, it is expected that GDP and exports will be positively correlated (Kravis, 1970). In addition, exports might stimulate output through a number of channels. McKinnon(1964) and Chenery and Strout (1966) point out that the foreign exchange earned from exports allows imports of intermediate and capital goods that increase production potential. Keesing (1967), Michaely (1977), Balassa (1978), Krueger (1980), and Tyler (1981) show that exports contribute to GDP by more than the export volume by pointing to the positive external benefits of exports, including greater capacity utilization, economies of scale, incentives for technological improvement, and more efficient management of the firm due to competitive pressures of foreign markets.

\section{Impact of exports on growth}

11. In our analysis, we examine the impact of a change in nominal exports on real GDP and the labor market in Mauritius. An external shock in one sector will not only have an impact on the output of this sector but it can also have a spillover effect on other sectors of the economy. In Mauritius, foreign exchange is the main source of wealth and the main driver of domestic consumption, given the high share of exports in total output.

\section{Our empirical analysis is based on a demand-oriented theory of growth, first} emphasized by Kaldor (1970) and then explored by McCombie and Thirlwall (1994). This paper will investigate the relationship between exports and growth, but unlike the above mentioned theories, it will not analyze the determinants of exports, ${ }^{3}$ and therefore exports are considered as a totally exogenous variable. In addition, this paper will include other demand variables such as consumption and investment in order to avoid an overestimation of the elasticity coefficient of exports.

13. Let us define:

$$
X_{t}=X_{S t}+X_{T t}+X_{O t}
$$

Where: $\mathrm{X}_{\mathrm{t}}$ is total exports of goods, $\mathrm{X}_{\mathrm{St}}$ is exports of sugar, $\mathrm{X}_{\mathrm{Tt}}$ is exports of textile, and $\mathrm{X}_{\mathrm{Ot}}$ are other exports. From this equation we have $\partial X_{t} / \partial X_{S t}=\partial X_{t} / \partial X_{T t}=\partial X_{t} / \partial X_{O t}=1$ implying that the elasticity of total exports to any of the sectors is equal to the ratio of the exports in this sector to total exports.

14. In order to compute the impact of a variation of exports on GDP, we use a simple dynamic ordinary least squares (OLS) estimation method to regress the real growth rate of the economy at time $\mathrm{t}\left(\Delta y_{t}\right)$ on the real change in consumption at time $\mathrm{t}\left(\Delta c_{t}\right)$, investment at

\footnotetext{
${ }^{3}$ In this case, it will not be necessary to introduce another equation to the model where exports are specified and could depend on world income and exchange rate.
} 
time t-1 $\left(\Delta i_{t-1}\right)$, and the nominal change in exports at time $\mathrm{t}\left(\Delta X_{t}\right)$. Results of this exercise should be taken with caution, since the sample period is short, as it stretches over 25 years only (1978-2002) and the data is annual. The equation is the following:

$$
\Delta y_{t}=\alpha \Delta c_{t}+\beta \Delta i_{t-1}+\gamma \Delta X_{t}+\xi_{t}
$$

15. It appears from the results that investment does not have a significant impact on the growth rate. Although this result appears to be worrisome, it could be the consequence of a data collection problem. Therefore, we introduced the growth rate for the period t- 1 to account for the investment and other factors. Thus the equation will become:

$$
\Delta y_{t}=\alpha \Delta c_{t}+\gamma \Delta X_{t}+\delta \Delta y_{t-1}+\xi_{t}
$$

Parameter estimates are:

$$
\begin{gathered}
\Delta y_{t}=0.47 \Delta c_{t}+0.13 \Delta X_{t}+0.27 \Delta y_{t-1}+\xi_{t} \\
\text { t-stat: }[3.84] \quad[3.26] \quad[2.60]
\end{gathered}
$$

The Durbin-Watson test did not show any serial correlation problem.

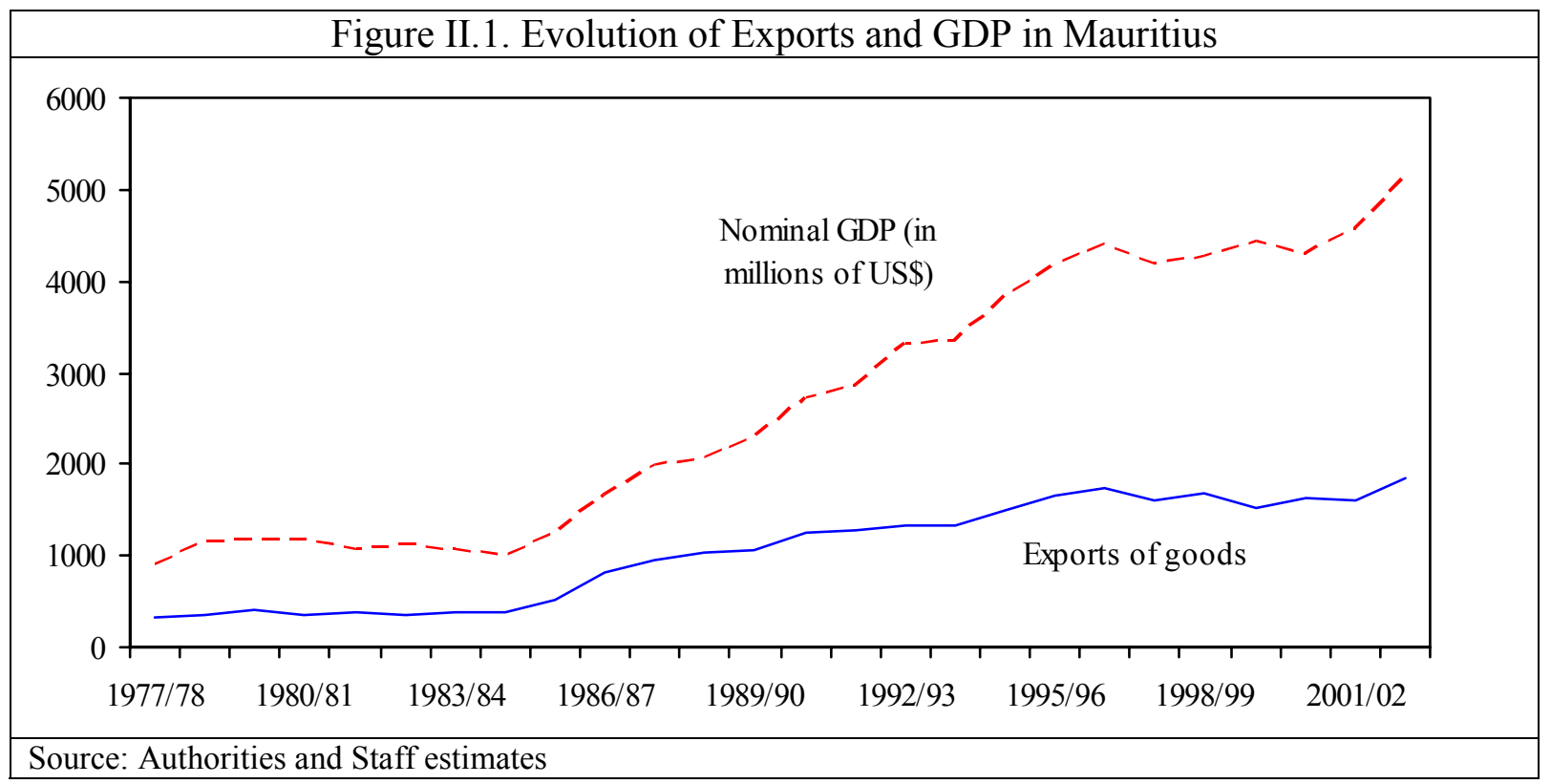

\section{Relationship between growth and the labor market}

16. The impact of exports on job creation is more uncertain, given that the impact is not only on jobs in export industries, but also on industries that distribute the outputs or supply the inputs. Increased exports are expected to increase production and jobs that are 
characterized by higher levels of worker productivity. As a result, higher wages could arise when the labor market is competitive. Trade, however, should lead to the elimination of jobs in less competitive industries. In Mauritius, in both sugar and textile sectors, international trade is affected by several constraints and world markets are not competitive. Mauritius has benefited from a quota system and is protected from foreign competition by bilateral or multilateral trade agreements. As a result, Figure II.2 shows that real compensation did grow faster than labor productivity in Mauritius, which has led to an increase in unit labor costs over the past twenty years.

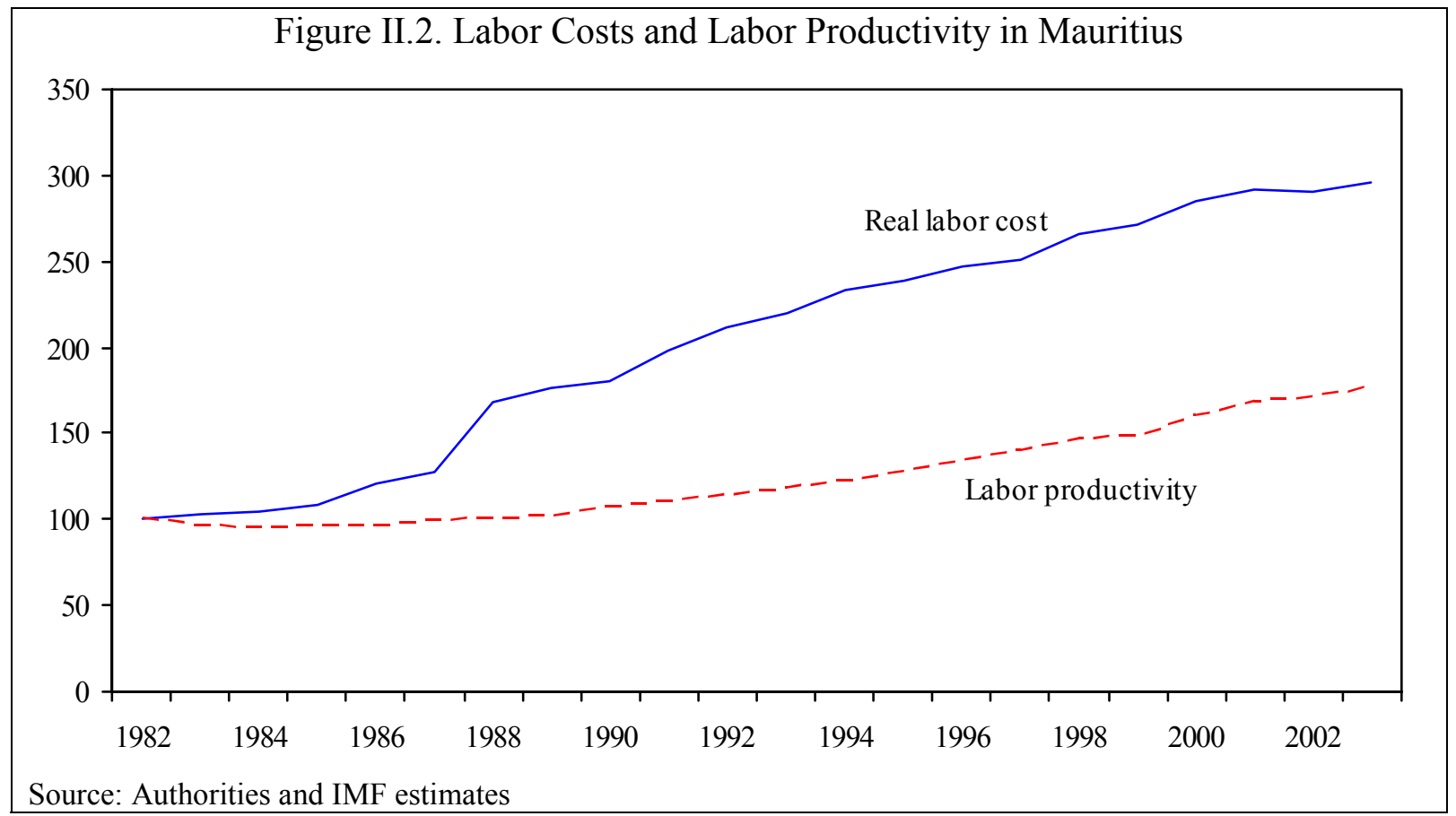

17. The main objective of this subsection is to compute the contribution of the labor costs to the value added of the sugar sector, which will help us to estimate the impact on employment of sugar trade liberalization. We assume a Cobb-Douglas production function of the Mauritian economy with constant returns to scale. ${ }^{4}$ Such a function links the quantity of labor, L, and capital, K, that are used for producing, each period t, the GDP Y.

$$
Y_{t}=L^{\alpha} K^{(1-\alpha)}
$$

Taking the logarithm of terms on both sides of the equation:

\footnotetext{
${ }^{4}$ It is important to note that this representation of the economy does not contradict our previous demand-oriented representation for economic growth, since both representations are independent, and the Cobb Douglas function is only used to derive contribution of Labor to the value added of the sugar sector.
} 


$$
y_{t}=\alpha l_{t}+(1-\alpha) k_{t}
$$

Where:

$y_{t}=\log Y_{t}, l_{t}=\log L_{t}, k_{t}=\log K_{t}$

We divide the economy into three sectors: the sugar sector $(\mathrm{S})$, the textile sector $(\mathrm{T})$ and other sectors $(\mathrm{O})$. Therefore we can rewrite equation (2) as:

$$
\begin{gathered}
y_{t}=y_{S t}+y_{T t}+y_{O t} \\
y_{t}=\alpha^{\prime} l_{S t}+(1-\alpha)^{\prime} k_{S t}+\alpha^{\prime \prime} l_{T t}+(1-\alpha)^{\prime \prime} k_{T t}+\alpha^{\prime \prime \prime} l_{O t}+(1-\alpha)^{\prime \prime \prime} k_{O t}
\end{gathered}
$$

With the assumption of constant returns-to-scale, the elasticity of output with respect to a given factor is equal to the share of its revenue (net wages, in case of labor) in total income, when factor markets are competitive. In the sugar sector, we have:

$$
Y_{S t}=L_{S t}{ }^{\alpha^{\prime}} K_{S t}{ }^{\left(1-\alpha^{\prime}\right)}
$$

Having marginal product equal to marginal cost and assuming that $\mathrm{w}_{\mathrm{St}}$ is the wage in real terms in the sugar sector and is $w_{S t}=W_{S t} / P_{S t}$, where $\mathrm{W}_{\mathrm{St}}$ is the nominal wage in the sugar sector and $\mathrm{P}_{\mathrm{St}}$ is the price index in the sugar sector, it follows:

$$
w_{S t}=\partial Y_{S t} / \partial L_{S t}=\alpha^{\prime} L_{S t}^{\alpha^{\prime}-1} K_{S t}^{\left(1-\alpha^{\prime}\right)}=\alpha^{\prime} Y_{S t} / L_{S t}
$$

This implies:

$$
\alpha^{\prime}=L_{S t} w_{S t} / Y_{S t}
$$

Where the computation of the average of $\alpha^{\prime}$ during the last four years gave us $\alpha^{\prime}=0.65$. The same reasoning could be applied to the textile sector and we will have:

$$
\alpha^{\prime \prime}=L_{T t} w_{T t} / Y_{T t}
$$

\section{Sugar Sector}

18. Mauritius's sugar sector is governed by two important agreements with the European Union. The two agreements are the African Caribbean and Pacific (ACP), European Union (EU) sugar protocol and the Agreement on Special Preferential Sugar (SPS). The fundamental principles enshrined in the sugar protocol are (i) agreed quantities of cane sugar, raw or white, (ii) guaranteed prices, and (iii) indefinite duration. The agreed quantities cannot be reduced without the individual consent of each concerned country. The guaranteed prices are in practice the same prices given to Community sugar producers. The ACP guaranteed prices are linked to the EU intervention price for the domestically produced raw sugar and the guaranteed price of white sugar to the derived intervention price in the U.K. 


\section{The sugar agreements}

19. The sugar protocol was annexed in 1975 to the Lomé Convention, which has regulated the trade and aid relations between the $E U$ and its ex-colonies (together with other protocols on bananas, rubber, rice, beef, and rum) since then. The protocol was revised and included in the new ACP/EU agreements that were signed in 2000 in Cotonou, Benin. The Cotonou Agreement provides for the continuation until 2007 of the Lomé arrangements for trade in goods. Between September 2002 and December 2007, the agreement calls for the negotiations of new trade arrangements to take effect no later than January 2008.

20. The new trade arrangements envisaged in the Agreement are referred to as "economic partnership agreements" (EPAs). There is also provision for a review of the negotiations in 2004, at which time the possibility will be explored of "alternative trade arrangements" for those ACP states that are not in a position to enter into EPAs with the EU. The Cotonou Agreement itself continues for 20 years, and its development assistance provisions will remain in force for the whole of this period. The trade provisions, however, expire in December 2007. There are thus no trade arrangements currently in place between the EU and the ACP states covering the period from January 2008 onward.

21. The SPS agreement was introduced in order to meet the needs of EU sugar refiners after the accession of Spain and Portugal to the EU. It was signed between the EU and the ACP countries in June 1995 for a period of six years, and it was renewed in 2001 for another five years. Unlike the ACP/EU sugar protocol, it is of a fixed duration and the ACP states are jointly and separately liable to supply the quantities of sugar covered by the SPS agreement. The conditions of the SPS agreement include a minimum delivered price to be paid by EU refiners, equivalent to approximately 85 percent of the ACP guaranteed price for raw sugar. Under the SPS, the European Community undertakes to open a special tariff quota for the import of raw cane sugar for refining originating in ACP states, on the basis of the needs determined by the Commission concerning the SPS. Although the agreement was renewed for the period 2001-06, the expected progressive reductions of the SPS quantities as a result of the Everything But Arms (EBA) initiative is a matter of concern for the ACP sugar exporting countries.

22. The EBA regulation grants duty-free and quota-free access to imports of all products from the least developed countries, with the exception of arms and munitions. It was adopted by the EU in February 2001 and covers 49 least-developed countries. The EBA foresees that the special arrangements for LDCs should be maintained for an unlimited period of time and not be subject to the periodic renewal of the Community's scheme of generalized preferences.

\section{The world sugar market}

23. In general, the competitive world market for sugar is of marginal importance. Only around 30 percent of world sugar production is exported and in almost every country the domestic sugar market is protected. Additionally, around one third of world sugar exports 
are based on preference agreements or long-term contracts. Consequently, only around 20 percent of world sugar production is traded under free market conditions.

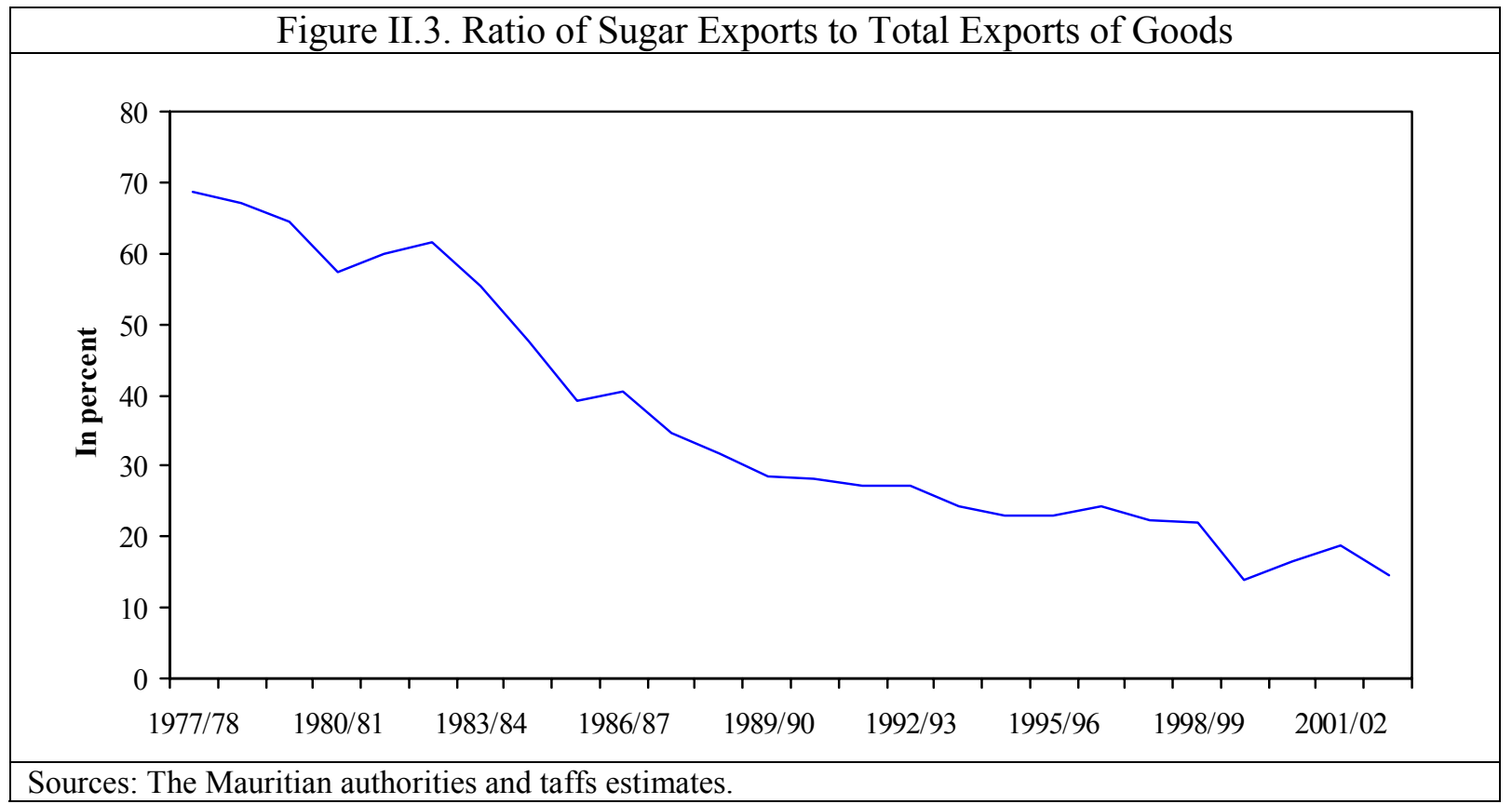

24. World demand for sugar is assumed to be inelastic to price changes. However, it generally depends on the economic situation in the importing countries. We can divide the world market into the liberalized market $\left(D_{1}, S_{1}, P_{1}, Q_{1}\right)$ and the preferential market $\left(D_{2}, S_{2}\right.$, $\mathrm{P}_{2}, \mathrm{Q}_{2}$ ), where $\mathrm{D}$ is the demand for sugar, $\mathrm{S}$ the supply of sugar, $\mathrm{P}$ the price, and $\mathrm{Q}$ the quantity. In both markets, the demand for sugar is relatively inelastic to price changes. Thus, we have:

$$
\begin{aligned}
& Q_{D t}=\alpha Y_{t}+\beta \\
& Q_{D 1}=A=c t e \\
& Q_{D 2}=B=c t e
\end{aligned}
$$

$\mathrm{Q}_{\mathrm{D} 1}$ is equal to 20 percent of the total world demand $\mathrm{Q}_{\mathrm{D}}$, and $\mathrm{Q}_{\mathrm{D} 2}$ constitute the remaining 80 percent.

On the supply side, the quantities supplied on both the liberalized and the preferential markets depend on weather conditions (WT). Nevertheless, prices in the liberalized market depend on the quantities supplied. Therefore,

$$
P_{1}=\alpha^{\prime} Q_{S 1}+\beta^{\prime}
$$

Since preferential prices are related to quotas and they are not related to the quantities supplied, it is safe to assume a fixed preferential price. 


$$
\begin{gathered}
P_{2}=C=c t e \\
Q_{S 1}=\delta+\gamma W T \\
Q_{S 2}=\delta^{\prime}+\gamma^{\prime} W T
\end{gathered}
$$

We can rewrite $P_{1}$ :

$$
P_{1}=\alpha^{\prime} \delta+\alpha^{\prime} \gamma W T+\beta^{\prime}
$$

25. The liberalization of the sugar market is expected to have adverse effects on high cost countries, and it will alter demand and supply functions, thus impacting prices.

Total world demand $\mathrm{D}$ will be the sum of the demands on the liberalized market $\mathrm{D}_{1}$ and the preferential market $\mathrm{D}_{2}$. Total supply is projected to decrease, since prices on the previous preferential market are expected to collapse, and several sugar producers will find themselves unable to compete due to their high production costs.

26. As a result, the equilibrium price level after liberalization is expected to be slightly higher than the actual equilibrium price in the liberalized market and much lower than the actual price in the preferential market. In a liberalized sugar market, several producers in industrialized countries will shift from producing sugarcane or beet to the production of other sweeteners such as the $\mathrm{HFCS}^{5}$ because of its lower production costs. It is also expected that the total supply slope will be steeper than in the actual liberalized market since producers will become more sensitive to any change in price as it will have an impact on their profitability.

\section{Liberalization impact}

27. We consider two scenarios for the sugar sector. The first one is a gradual decrease in sugar prices in the coming years. The Mauritian economy will therefore have some time to adapt to the declining prices. The second scenario is a more extreme case and assumes a full liberalization of sugar prices beginning 2005.

28. In the moderate scenario, we assume that prices will be reduced in 2005 to the average world price of US\$0.16/lb. The price will then decrease to US\$0.13/lb in 2006, and US $\$ 0.10-0.12 / \mathrm{lb}$ in 2007 , and US $\$ 0.10 / \mathrm{lb}$ in 2008 . Recall from section B that the elasticity of GDP to exports is 0.13 , and the elasticity of total exports to sugar exports is of 0.14 . For the fiscal year 2004/05 (July-June), some caution is warranted, since it will depend on when the sugar crop is sold. If the prices are set to decrease starting 2005 and the stock of sugar is sold before the end of 2004, then the impact of the price decrease on fiscal year 2004/05 will be

\footnotetext{
${ }^{5}$ HFCS is a synthetically sugar obtained from fructose which is a very sweet sugar derived from dextrose. Dextrose is a sugar derived synthetically from starch and most commonly from corn.
} 
amortized, but if the bulk of the crop is sold in 2005, then there will be a full impact of the price decrease on exports and thus on GDP growth.

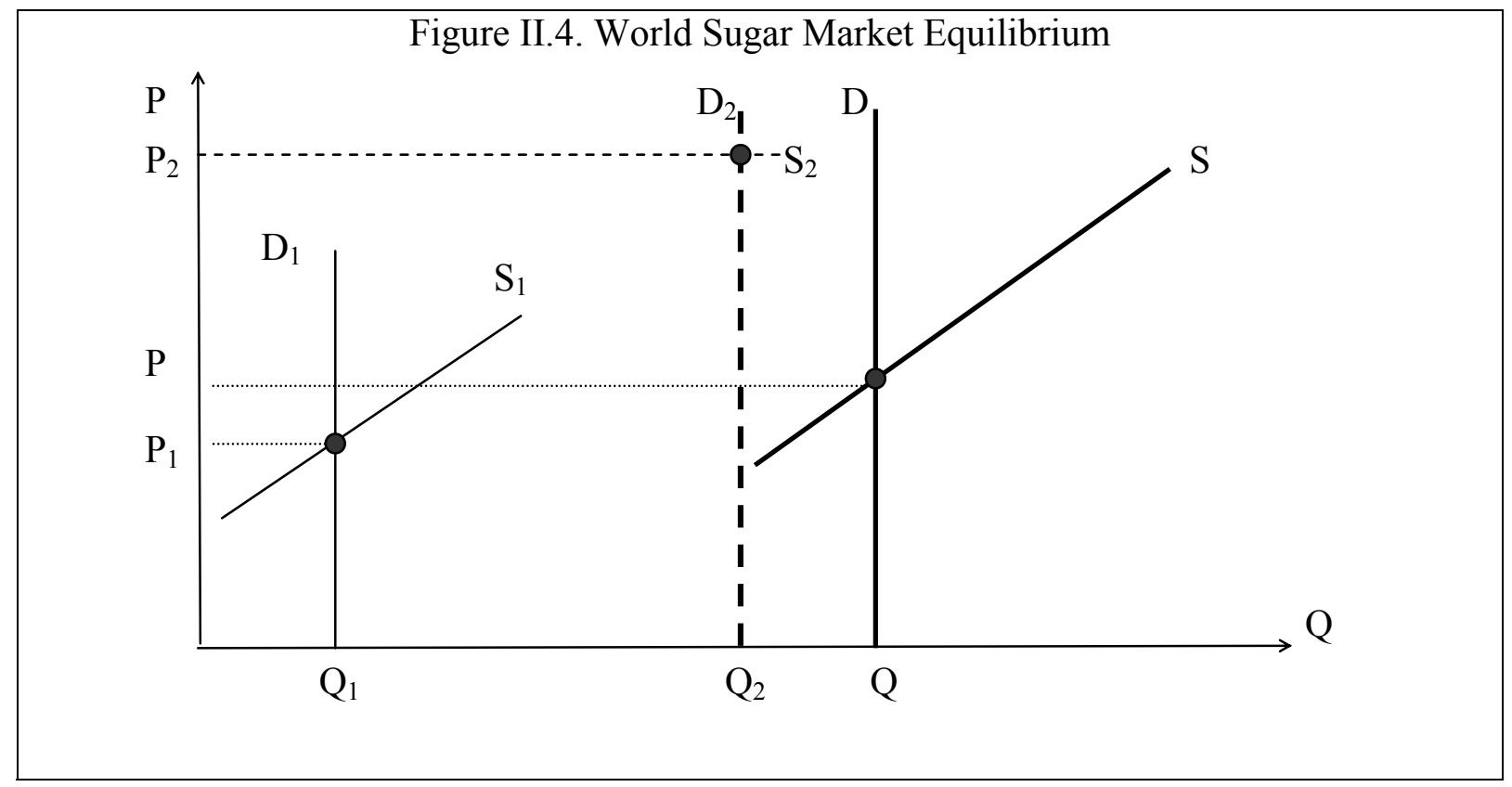

Table II.1. Growth Impact of Sugar Price Decline

\begin{tabular}{lccc}
\hline & $2004 / 05$ & $2005 / 06$ & $2006 / 07$ \\
\hline Price decline & 30 percent & 19 percent & 15 percent \\
$\begin{array}{l}\text { Decline of total } \\
\text { exports }\end{array}$ & $2-4$ percent & 3 percent & 2 percent \\
$\begin{array}{c}\text { Deviation of } \\
\text { GDP growth } \\
\text { from baseline }\end{array}$ & $0.2-0.5$ percentage point & 0.4 percentage point & 0.3 percentage point
\end{tabular}

29. For Mauritius's sugar sector to compete on the world market, the strategy to reduce costs should be implemented without delay. This will necessitate reducing the costs from US\$0.14 per pound in 2005 to US\$0.10 per pound in 2008. Costs reduction from US $\$ 0.18$ per pound in 2001 to US\$0.14 per pound in 2005 is expected to result in job losses of 7,900 jobs in the sugar sector, bringing the total working force to around 21,000 workers. Recalling equation (7) from section $\mathrm{B}$, we computed $\alpha^{\prime}=0.65$. As a result, the reduction of the costs to US $\$ 0.10$ per pound by 2008 , all other things being constant, will necessitate a decrease in the sugar sector labor force by up to an additional 2,800 workers.

30. In the extreme scenario, the shocks would have a much stronger impact on the different sectors of the economy. One assumption — although with low probability — would 
be for the WTO panel to decide on the complete liberalization of the sugar trade in 2005. This would most likely cause world sugar prices to drop to around US\$0.10-0.12 per pound ${ }^{6}$ for raw sugar from the actual preferential prices between US\$0.20-0.24, and compared to an actual international price level of between US\$0.06 and 0.07 per pound. Only a few countries-Brazil, Australia, Thailand, and to some extent, South Africa - would be able to sell sugar at the current world prices.

31. The equilibrium price level will depend on the reactions of industrial countries to trade liberalization. If no direct subsidies are allocated to farmers in industrial countries, producers will likely abandon sugar cane or beet production and will move to other sweeteners such as the HFSC mentioned earlier.

32. Under this scenario, the cost of sugar production in Mauritius would be some 40 percent higher than the world price and could lead to losses in the sector of around US\$60 million in $\mathbf{2 0 0 5 / 0 6}$ for a total production of $\mathbf{6 0 0 , 0 0 0}$ tons. These losses would continue until production costs are reduced to around US $\$ 0.10$ per pound in $2007 / 08$, as called for under the sugar sector strategy.

\section{Textile Sector}

\section{Textile agreements}

33. The Multi-Fiber Agreement (MFA) has had a marked impact on the global textile industry since its coming into force in 1974. The MFA governed world trade in textiles and garments and provided the basis on which industrialized countries have been able to restrict imports from developing countries. Quotas have been negotiated on a country-bycountry basis and have been established at different levels. This has affected the ability of industries to expand. For example, strict quotas generally operated on imports from Korea and Hong Kong, while the EU imposed no restrictions on textile and clothing imports from a group of least-developed countries (EBA initiative).

\section{In 1994, the ATC was introduced with the objective to phase out the MFA} restrictions over a period of 10 years. It outlines a program for the integration of all products into WTO rules by 2005, and applies to all WTO members, whether or not they were signatories of the MFA. The MFA and ATC cover trade in cotton, wool, and man-made fiber products. Existing quotas would be removed by progressively increasing permitted levels, although it has been heavily back-loaded to January 2005.

\footnotetext{
${ }^{6}$ This assumption should be taken with caution since the reaction of the supply, in case of liberalization, is very uncertain due to the fact that a large proportion of world sugar producers have higher production costs, and a large portion of world sugar supply is subsidized.
} 
35. The ATC allows importing countries to integrate products that were not restricted in the first place, which is the reason why the integration has not made a big impact on international trade in textile and clothing. The removal of quotas for the most sensitive products (e.g., T-shirts, men's shirts, ladies' blouses, and jeans) will take place only at end-2004. Therefore, none of Mauritius's main production lines have so far been affected by the phasing out of quotas under the ATC.

36. In addition, by not stipulating proportions of the product types to be integrated, the ATC allows importers to liberalize largely in the lower value sectors, thus maintaining discrimination against value-added imports and protecting their own valueadded clothing industries. For example, in the first tranche of liberalization, 70 percent of the products integrated were yarns and fabrics.

37. Some countries will gain from the phasing out of textile quotas under the ATC while others will lose. The expectation is that there will be an increase in the relocation of the garment industry from industrialized to developing countries. Moreover, the major relocations could be from one relatively poor country to another. The MFA did have the effect of guaranteeing developing countries with high production costs access to northern markets costs. Without the MFA there will be a more open market and the overall result is likely to be a concentration of the industry in a smaller number of low-cost locations. Marginal suppliers are likely to be squeezed out. Mauritius is an example of a country that it is likely to be among the losers, since its textile industry has higher unit labor costs than other countries such as China, Madagascar, and other Asian and African countries.

38. Mauritius is also benefiting from the African Growth and Opportunity Act (AGOA) that was promulgated in the United States in May 2000 for a period of eight years. AGOA significantly liberalizes access to the U.S. market for 37 Sub-Saharan African Countries (out of a total of 48). However, recent amendments to AGOA (AGOA II) have resulted in the elimination of Mauritius from the list of Lesser-Developed Countries, and therefore Mauritius was unable to use non-qualifying third-country textile inputs in the manufacture of AGOA-eligible apparel exports. As a result, only 40 percent of Mauritius's exports in the "textiles and apparel" category qualify for AGOA benefits.

\section{Current situation of the textile industry in Mauritius}

39. Output of the Mauritian textile industry, which constitutes about 80 percent of the EPZ, has been declining in the last few years. The knitwear sub-sector has been adversely affected by the delayed resolution of whether garments that are "knitted to shape" qualify for preferential access under AGOA. Many of the Hong Kong based textile firms - which account for around 25 percent of textile employment (around 15,000 workers) and 30 percent of exports - are likely to leave in the next two to three years. 


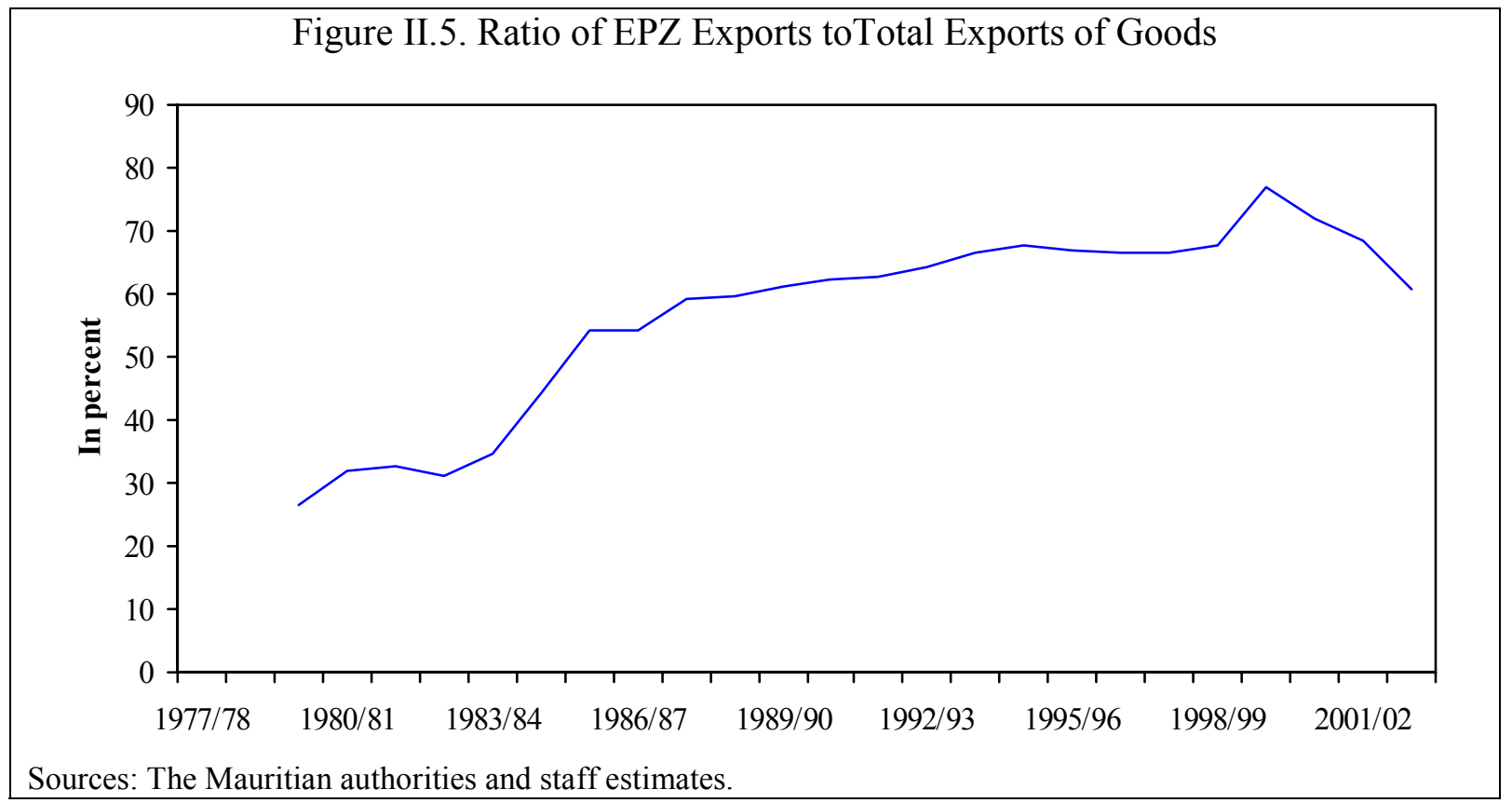

40. The authorities have been supporting the restructuring of EPZ textile firms in order to avoid a possible collapse of the sector. These efforts have resulted in the establishment of the Textile Emergency Support Team (TEST) initiative in July 2003. The TEST has commissioned the National Productivity and Competitiveness Council (NPCC) to carry out a diagnostic study of textile firms to assess their cost structure and point to areas for improvement. The government will provide funding for consultants to assist potentially viable firms to rehabilitate their operations. In addition, a corporate debt restructuring committee (CDRC) — chaired by the Managing Director of the Bank of Mauritius - has also been established to facilitate (in coordination with creditors) the restructuring of the debts of potentially viable firms.

\section{The NPCC performed the level one assessment on $\mathbf{4 2}$ firms and found that $\mathbf{1 6}$ of} them are healthy, 6 promising, 11 vulnerable, and 9 at risk of closing. In 2002, the healthy and at-risk firms each accounted for more than a third of textile employment, the vulnerable firms for 24 percent, while the promising companies for only around 3 percent. More troublingly, the at-risk firms are, on average, much larger than any of the other types of firms, being on average 80 percent larger than the healthy firms, the next largest.

\section{Another important development that could adversely affect the textile industry} is the enforcement of the Ralph Lauren trademark following negotiations with manufacturers of the brand. In 1992, the Mauritian Government granted a Ralph Lauren trademark to a local firm. This trademark was not renewed after it expired in 2000, which led a number of local firms (in the absence of a legal holder of the trademark), to start producing Ralph Lauren products. It is estimated that the firms employ around 7,000 workers. In the first quarter of 2004, Ralph Lauren enforced its trademark rights and reached a settlement agreement, whereby the concerned firms are required to dispose of their remaining stocks by 
end-December 2004. A monitoring committee, headed by the Managing Director of the Bank of Mauritius, has been established to verify stocks on a monthly basis.

\section{Empirical analysis}

43. The phasing out of textile quotas under the ATC could lead to the textile sector shrinking by 8 percent in 2004/05, 15 percent in 2005/06, 8 percent in 2006/07, and stabilizing thereafter (the moderate scenario). These assumptions are based on the TEST initiative, which identified that the firms at risk of closing down employ around 8,700 workers and the vulnerable firms employ 5,700 workers. Given that the number of firms that chose to go through the TEST initiative is 42 , and the total number of textile firms is above 280 , it can be assumed that other companies at risk have not yet approached the TEST initiative. In addition, foreign firms employ more than 15,000 workers. Assuming that firms from Hong Kong will relocate and other domestic firms will also close down or relocate to Madagascar, especially in the "pull-over" sub-sector, this could represent up to 20,000 job losses in the textile sector in the coming two to three fiscal years. While textile quotas will be phased out by end 2004, it is expected that a large part of the closures will take place in 2005/06, since companies can still process orders by end 2004 .

44. Rising labor costs is a major reason for the decline in competitiveness of the textile sector. In the EPZ sector, average compensation grew by nearly twice as fast as labor productivity-10.9 percent compared to 5.7 percent $^{7}$.

45. Given that textile exports constitute around 48 percent of total exports, the impact of a moderately severe textile shock on GDP growth is summarized in the following table.

Table II.2. Growth Impact of Moderate Textile Shock

\begin{tabular}{lccc}
\hline & $2004 / 05$ & $2005 / 06$ & $2006 / 07$ \\
\hline $\begin{array}{c}\text { Decrease in } \\
\text { textile exports }\end{array}$ & 8 percent & 15 percent & 8 percent \\
$\begin{array}{c}\text { Decline of total } \\
\text { exports }\end{array}$ & 3.8 percent & 7.2 percent & 3.8 percent \\
$\begin{array}{c}\text { Impact on GDP } \\
\text { growth }\end{array}$ & 0.5 percentage point & 0.94 percentage point & 0.5 percentage point \\
\hline
\end{tabular}

46. The phasing out of textile quotas could have a more severe impact—although with lower probability — on economic growth in Mauritius. An extremely severe scenario could involve the closure of all textile firms categorized as either vulnerable or at risk under the TEST initiative, in addition to the relocation of foreign and some local companies to

\footnotetext{
${ }^{7}$ See the chapter on the labor market in Mauritius.
} 
other countries with lower costs. The total impact would be a decline in the textile sector of more than 20 percent in 2004/05, 30 percent in 2005/06, and 10 percent in 2006/07. The impact on total exports and economic growth is illustrated in the table below.

Table II.3. Growth Impact of Severe Textile Shock

\begin{tabular}{lccc}
\hline & $2004 / 05$ & $2005 / 06$ & $2006 / 07$ \\
\hline $\begin{array}{c}\text { Decrease in } \\
\text { textile exports }\end{array}$ & 20 percent & 30 percent & 10 percent \\
$\begin{array}{c}\text { Decline of total } \\
\text { exports }\end{array}$ & 9.5 percent & 14.4 percent & 4.8 percent \\
$\begin{array}{c}\text { Impact on GDP } \\
\text { growth }\end{array}$ & 1.24 percentage point & 2 percentage point & 0.6 percentage point \\
\hline
\end{tabular}

\section{Impact of a combination of shocks}

47. The big challenge facing the Mauritian economy is the simultaneous occurrence of negative shocks in the sugar and the textile sectors. When aggregated, these sectors constitute more than 60 percent of the total exports of goods. Therefore, the impact on economic growth from the combination of both shocks could be substantial. The largest impact would be felt in 2005/06. A combination of extreme shocks in both sectors could reduce economic growth by more than 2 percentage points. The estimates are summarized below.

Table II.4. Growth Impact of Combined Sugar and Textile Shocks

\begin{tabular}{|c|c|c|c|c|c|c|c|}
\hline \multirow{3}{*}{\multicolumn{2}{|c|}{$\begin{array}{l}\text { Impact on GDP growth (in } \\
\text { percentage points) }\end{array}$}} & \multicolumn{6}{|c|}{ Sugar Sector Shocks } \\
\hline & & \multicolumn{3}{|c|}{ Moderate shock } & \multicolumn{3}{|c|}{ Extreme shock } \\
\hline & & $2004 / 05$ & $2005 / 06$ & $2006 / 07$ & $2004 / 05$ & $2005 / 06$ & $2006 / 07$ \\
\hline \multirow{3}{*}{$\begin{array}{l}\text { Textile } \\
\text { Sector } \\
\text { Shocks }\end{array}$} & Moderate shock & $0.6-1$ & 1.34 & $0.5-0.8$ & $1.1-1.4$ & $1.1-1.45$ & 0.5 \\
\hline & & & & & & & \\
\hline & Extreme shock & 1.75 & 2.4 & 0.9 & $1.85-2.15$ & $2.2-2.5$ & 0.65 \\
\hline
\end{tabular}

\section{E. Concluding Remarks}

48. Mauritius's medium-term economic prospects are clouded by the impending loss of trade preferences. Baseline economic growth is expected to register an average of 4 percent per annum, a 2 percentage points decline from the historical average. This growth rate could decrease to less than 2 percent, leading to substantial increase in the unemployment rate, depending on the severity of the impact of a liberalization of international trade in sugar and textiles.

49. In anticipation of the coming shocks, the government has already started implementing reforms to adapt the economy to the new challenges. The authorities 
embarked on a restructuring plan for the sugar as well as for the textile sectors. They are also trying to diversify the economy through the promotion of the information and communication technologies (ICT) sector, financial services, and tourism. While ICT could present a potential source for development, it may take longer than expected in order for the new sector to have its full impact on the economy.

\section{However, a critical factor that constrains the restructuring and the} diversification efforts is labor market rigidity. Reforms in this area are discussed in a subsequent chapter, which focuses on the need to reform the centralized wage bargaining system and the current restrictions on the redeployment of labor. Reforms to the educational system and the need to address the skills mismatch in the economy were discussed in McDonald and Yao (2003).

\section{References}

Ballassa, Bela, 1978, "Exports and Economic Growth: Further Evidence," Journal of Development Economics, 5, pp. 181-189.

Chenery, Hollis B. and Strout, Alan, 1966, "Foreign Assistance and Economic Development," American Economic Review, 56(4), pp. 679-733.

Edwards, Sebastian, 1993, “Openness, Trade Liberalization, and Growth in Developing Countries," Journal of Economic Literature, Vol. XXXI, 1358-93.

Eicher, Theo S., 1999, “Trade, Development and Converging Growth Rates: Dynamic Gains from Trade Reconsidered," Journal of International Economics, 48 (1), pp.179-198.

Fajgenbaum, Jose, Sharer, Robert, Thugge, Kamau, and DeZoysa, Hema, 1999, "The CrossBorder Initiative in Eastern nad Southern Africa," IMF Staff Report.

Feder, Gershon, 1983, “On Exports and Economic Growth,” Journal of Development Economics, 12, pp. 59-73.

GATT, 1974, "Arrangement Regarding International Trade in Textiles.”

Kaldor, N., 1970, “The Case for Regional Policies," Scottish Journal of Political Economy, pp. 337-348.

Keesing, Donald B., 1967, "Outward-Looking Policies and Economic Growth: Further Empirical Evidence," Journal of Development Economics, 14, pp. 241-250.

Kravis, Irving B., 1970, "Trade as a Handmaiden of Growth: Similarities Between the Nineteenth and Twentieth Centuries," Economic Journal, 80 (320), pp. 850-872.

McKinnon, Ronald I., 1964 “Foreign Exchange Constraint in Economic Development 
and Efficient Aid Allocation,” Economic Journal, 74, pp. 388-409.

Mauritius Employers' Federation, 2004, “The Situational Analysis: Worrying Structural Problems," Memorandum on Wages Policy.

McCombie, J.S.L., and A.P.Thirlwall, 1994, "Economic Growth and the Balance of Payments Constraint," St. Martin's Press.

McDonald, Calvin, and James Yao, 2003, "Mauritius: Unemployment and the Role of Institutions," IMF Working Paper, WP/03/211.

Michaely, Michael, 1977, "Exports and Growth: An Empirical Investigation,” Journal of Development Economics, 4, pp. 49-53.

Mitchell, Donald, 2004, "Sugar Policies: Opportunity for Change,” World Bank Working Paper No. 3222.

Pritchett, Lant, 1996, "Measuring Outward-Orientation in LDCs: Can it be Done?" Journal of Development Economics, 49(2), pp. 307-335.

Rutherford, Thomas F., and David G. Tarr, 1999, "Blueprints, Spillovers, and the Dynamic Gains from Trade Liberalization in a Small Open Economy," Dynamic Issues in Applied Commercial Policy Analysis, pp. 269-316.

Tyler, William G., 1981, "Growth and Export Expansion in Developing Countries: Some Empirical Evidence," Journal of Development Economics, 9, pp. 121-130.

Zimmermann, Beate, and Jurgen Zeddies, 2000, "International Competitiveness of Sugar Production," University of Hohenheim. 


\section{Mauritian Labor MARKet InStitutions AND LoW-SKILL EMPLOYMENT ${ }^{8}$}

\section{A. Introduction}

51. Notwithstanding impressive economic growth, Mauritian unemployment has increased in every year since 1991, with the unemployment rate reaching 10.2 percent in 2003. As in many countries, this unemployment is primarily experienced by low-skill workers. ${ }^{9}$ In response to this growing unemployment problem, the government has begun to address the problem of apparent skills mismatch through far-reaching educational reforms. ${ }^{10}$ However, as shown in this paper, educational reform can only be a partial solution to the unemployment problem.

52. In the face of strong economic growth, such an increase in unemployment suggests the root of the problem could lie in Mauritius's labor market institutions. These institutions - which compress the wage distribution and limit the ability of employer's to redeploy their workers - may have seriously impaired the functioning of the labor market. While they may not have resulted in significant unemployment in earlier decades, the increasing importance of (high-wage) service sectors in Mauritius, which have increased the impact of cross-market wage compression, as well as the gradual decline in the demand for low-skill workers, will probably exacerbate the impact of these institutions.

53. The impact of these restrictions will become increasingly detrimental as Mauritius faces significant structural challenges - considerably changing the market for low-skill workers-in coming years. The most significant of these challenges is the eventual loss of preferential arrangements for its sugar and textile exports. While it is still uncertain when the preferential sugar regime will end, Mauritius's quota under the Agreement on Textiles and Clothing (ATC) is set to lapse by end-2004. Although the preferential access granted under the U.S. African Growth and Opportunity Act (AGOA) may mitigate some of this impact, the Mauritian economy will undoubtedly go through a period of restructuring, as the textile sector adjusts to its new environment. As discussed in Section B, signs of adjustment are already evident in the textiles industry. Changes in the demand for sugar workers have already begun with the government's Sugar Sector Strategy,

\footnotetext{
${ }^{8}$ Prepared by Nathan Porter.

${ }^{9}$ The 2000 Census reported that 90 percent of the unemployed have not completed the high school certificate.

${ }^{10}$ A common measure of mismatch in the labor market - the variance of relative unemployment rates across categories - suggests that mismatch may have actually declined between the 1990 and 2000 censuses. Using labor market data by educational category, the variance of relative unemployment rates has declined from 17 percent to 12 percent. The intuition for this measure is that the greater the dispersion in unemployment rates, the greater the mismatch in the labor market (Layard, Nickell, and Jackman, 1991, Ch. 6).
} 
which has reduced employment by around a quarter. By delaying reform of its labor market institutions, Mauritius will exacerbate the pain involved in this adjustment, especially for those with few skills.

54. In light of these challenges, this paper analyzes the market for low-skill workers, who risk being neglected as the government focuses on developing other sectors. With the export processing zone (EPZ) being an important source of low-skill employment, the paper first investigates the evolution of this sector (in Section B). In Section C, a simple stylized model of the job creation and destruction processes is employed to assess the potential benefits of labor market reform. The results suggest that even relatively minor wage compression and restrictions on the redeployment of workers can have dramatic impacts on the fragility of jobs, and the extent of unemployment and labor market churning. ${ }^{11}$

55. As such, this paper complements the work of McDonald and Yao (2003), who looked at the impact of Mauritius's institutions on the prospects for developing new sectors, and the consequent labor market transition. This paper concentrates on how these institutions impact on the prospects for low-skill workers by changing the incentives to create and destroy jobs - in both new as well as existing areas - that they are able to perform. With these workers the most likely to suffer from the structural transformation, deregulation could potentially improve the labor market conditions these workers face in a relatively short space of time.

\section{Mauritius's labor market institutions}

56. The Mauritian labor market is highly regulated, with wages and conditions of employment determined centrally rather than at the firm level. The government establishes a separate set of labor market regulations, called Remuneration Orders (RO), for each industry. ${ }^{12}$ These regulations specify the exact duties of every type of worker in great

${ }^{11}$ In this context, the fragility of a job refers to the likelihood it is destroyed. By relative wage compression we mean that - possibly due to centralized wage determination - the wages paid to workers are artificially more similar than they would be if wages were the result of firm-level bargaining (Bertola and Rogerson, 1997). This means that differential wages do not fully reflect differences in productivity or working conditions. More specifically, this could mean that wages in a particular sector are "linked" to wages in a higher paying sector (cross-market compression), and/or that wages within an industry are closer to each other, although the average wage is much the same (within-market compression). Invariably, both of these types of compression occur.

12 For example, the RO for the catering industry defines "assistant barman," "barman," and "head barman" as separate occupations, with each unable to perform the duties of the otheran "assistant barman" cannot prepare a drink if a "barman" is at the bar. These regulations do not cover the EPZ sector, and are not expected to cover new information, communications and technology (ICT) activity. 
detail. With these regulations being aggressively enforced by the Ministry of Labor, worker redeployment is extremely difficult. Therefore, wages and conditions do not reflect the productivity or circumstances of individual firms. Moreover, terminations tend to be costly and time consuming, requiring approval of the Termination of Contracts Services Board, and often leading to delays on the order of four months.

\section{The centralized wage determination process tends to compress the wage}

distribution. Basic wages for each occupation are set in the $\mathrm{RO}$, with the annual tri-partite wage-setting process resulting in a new wage for all categories. In most years this process results in wage growth indexed to inflation, with lower wages rising by more than higher ones. Once every five years, the Pay Research Bureau establishes a catch-up wage increase for the public sector, which typically puts some additional pressure on private sector wages.

58. The ability of the economy to adjust in the face of its structural challenges will be inhibited by these regulations (Section $\mathrm{C}$ ). With wages being compressed and workers unable to be redeployed as circumstances change, jobs become substantially more fragile. Moreover, the incentive to create new jobs can also be reduced significantly. Therefore, even with the government encouraging the creation of new industries, such as the information, communication, and technology (ICT) sector, many of these opportunities, at least for some time, may bypass much of Mauritius's low-skill workforce. Employment opportunities for these workers can be enhanced over the medium term by simply liberalizing the regulations that govern the labor market.

\section{B. Evolution of Employment in the EPZ (Textiles) Sector ${ }^{13}$}

59. Textile production, especially in the EPZ sector, has contributed significantly to the Mauritian "growth miracle." Figure III.1 shows the decomposition of EPZ employment growth into its separate components - job creation and job destruction-since 1983. ${ }^{14}$ This figure shows the remarkable transformation that occurred in the early 1980s, before the extent of job creation and destruction stabilized around their longer-term values. This figure also shows that the creation and destruction of jobs is a persistent and continual process of renewal, with sizable job destruction occurring even during periods of high employment growth. This continual creation and destruction suggests substantial "reallocation" of activity across firms within the EPZ sector. Figure III.2, which depicts the job reallocation and excess job reallocation rates, shows that the exceptional job reallocation

${ }^{13}$ With textiles accounting for almost 90 percent of EPZ sector employment, textiles and EPZ will be referred to interchangeably in this section.

${ }^{14}$ The job creation, destruction, and employment growth rates used in this section are calculated by dividing the change in employment between two periods by the average employment in those periods. While slightly different from the standard definition of growth rates, it is consistent with the definition typically applied in the job flows literature - see Davis, Haltiwanger, and Schuh (1997). 
seen initially, reflecting the rapid creation of new EPZ sector jobs during the early-1980s, subsequently declined as the industry matured. ${ }^{15}$ As measured by the excess job reallocation rate, the extent of churning in the labor market also declined as the industry matured.

60. Quarterly job creation and destruction data show signs of a weakening in textiles during 2003. Figure III. 3 shows the quarterly decomposition of employment growth (from March 1986 to September 2003), and is analogous to Figure III.1. This figure also shows the rapid growth in EPZ employment in the mid-1980s, before a moderation in employment growth took place throughout the 1990s. However, the data for the first three quarters of 2003 show a substantial decline in the rate of job creation (to its lowest level ever), and a rapid increase in the rate of job destruction. In addition, Figure III.4 shows a marked increase in the average size of firms closing down in the last two years. Although relatively recent, the dramatic nature of the increase in job destruction and the decline in job creation in the last year would be consistent with a rapid structural decline in Mauritian textiles. While the industry is unlikely to - even in the long-run - disappear completely, it could very well be much smaller in the coming years.

\section{Mauritius's restrictive labor market institutions mean that it shares many} characteristics with other highly regulated labor markets, such as those in Western Europe. In addition to Mauritius's relatively high unemployment, unemployed workers face exceptionally long spells, with an average (median) unemployment duration of 20 (9) months. Moreover, consistent with the stagnant nature of the unemployment pool, Mauritius has relatively low rates of job flows. Table III.1 compares the rates of job creation and destruction in the U.S., Portuguese manufacturing, and the Mauritian EPZ sector (which is predominantly textiles). The Mauritian and Portuguese labor markets tend to exhibit much smaller quarterly job flows than seen in the U.S., suggesting they are less dynamic than the relatively unregulated U.S. one. That is, flows of workers into and out of unemployment seem much less frequent, thereby leaving the unemployed stranded for longer.

\footnotetext{
${ }^{15}$ Following Davis, Haltiwanger, and Schuh (1997), the job reallocation rate is defined as the sum of job creation and destruction rates. This definition reflects the fact that reallocation of jobs and workers from one type of activity to another typically requires the creation of jobs at expanding enterprises and destruction of jobs at contracting ones. Defined in this way, job reallocation also equals the maximal reallocation of workers induced by the reshuffling of employment opportunities across enterprises. The excess job reallocation rate is defined as job reallocation in excess of absolute employment growth, indicating the reallocation of jobs above the amount required to accommodate net employment changes, and may be also thought of as a measure of "churning."
} 


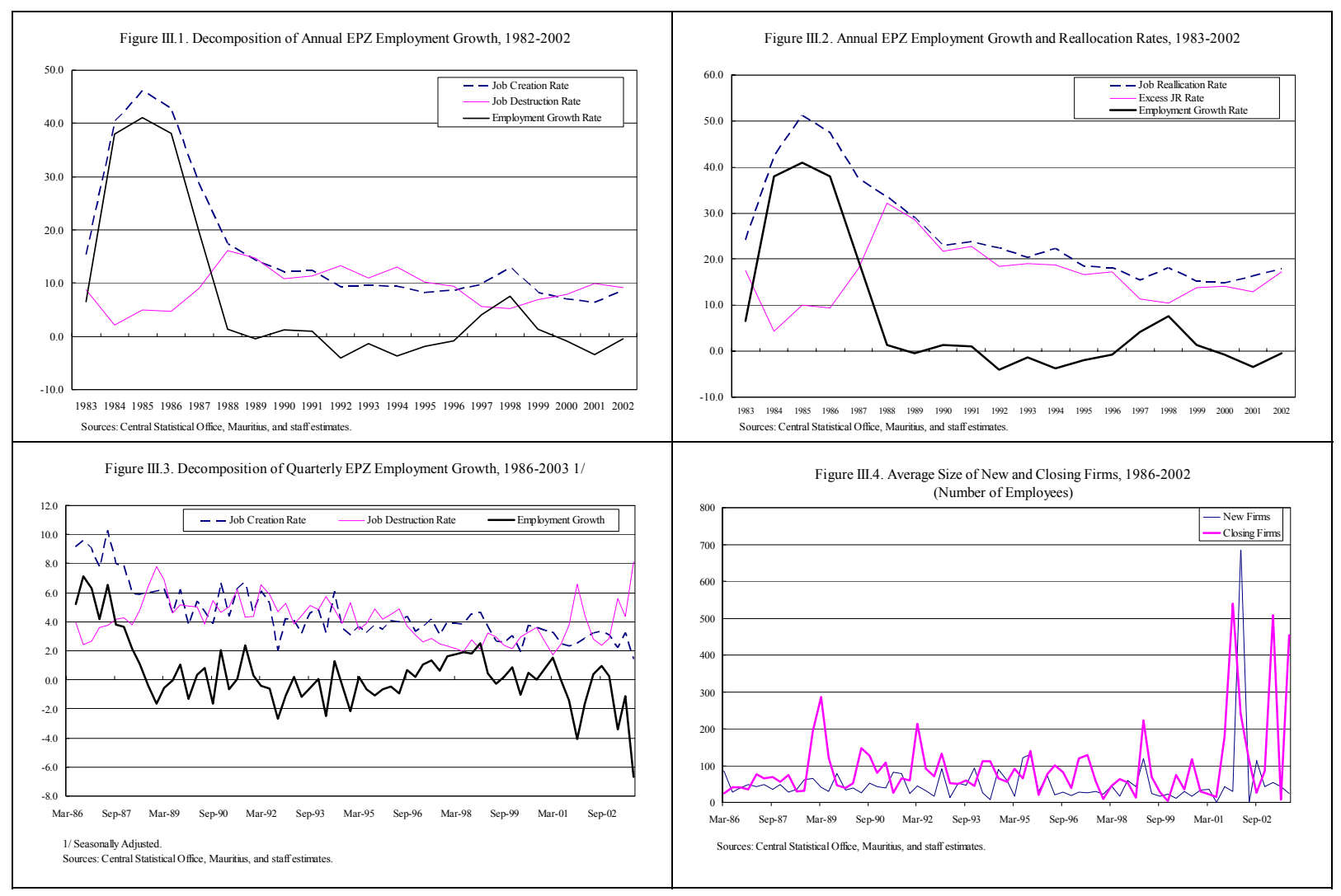

\section{An Assessment of the Impact of Wage Setting and Redeployment Restrictions}

62. This section investigates the impact of labor market institutions that compress wages and inhibit the redeployment of workers by using a calibrated version of a simple labor market-matching model. It finds that even relatively small distortions can have substantial effects on employment. One advantage of the type of model employed here is that it explicitly captures the frictional nature of labor markets. The model used in this section is specifically chosen to emphasize the effect of institutions on the creation and destruction of jobs and unemployment. The structure of the model used in this exercise is fairly standard, being that developed by Pissarides (2000) and Mortensen and Pissarides (1994). The impact of Mauritius's labor market institutions will be assessed using a calibrated version of this model. $^{16}$

\section{The structure of the model economy is one where a large number of} entrepreneurs can create job openings whenever it is profitable. Once created, the entrepreneur searches for a worker to fill the position which, depending on the extent of frictions in the market, may be very difficult and time consuming. When a worker and an entrepreneur meet, they, if allowed, bargain over the wage and decide whether to work together, thereby creating a job. However, if the government legally imposes the wage to be

16 The technical details of this exercise are outlined in the appendix. 
paid, production only occurs if profitable at that given wage. The profitability of these jobs evolves in a persistent manner over time, reflecting changes in demand and technology. If, as a result of this evolution, the job becomes unprofitable, the entrepreneur will destroy it and possibly create a new job opening, while the worker becomes unemployed and is able to search again.

Table III.1. Quarterly Job Flows Rates

\begin{tabular}{|c|c|c|c|}
\hline Country & Sector & Job Creation & Job Destruction \\
\hline \multirow[t]{3}{*}{ U.S. } & & \multicolumn{2}{|c|}{ 1972(2)-1993(4) } \\
\hline & Manufacturing & 5.07 & 5.47 \\
\hline & Apparel and Textiles & 4.58 & 5.40 \\
\hline \multirow[t]{3}{*}{ Portugal } & & \multicolumn{2}{|c|}{ 1991(1)-1995(4) } \\
\hline & Manufacturing & 3.20 & 3.90 \\
\hline & Portugal/U.S. 1/ & 0.63 & 0.71 \\
\hline \multirow[t]{3}{*}{ Mauritius } & & \multicolumn{2}{|c|}{ 1989(1)-2003(1) } \\
\hline & EPZ & 3.96 & 4.02 \\
\hline & Mauritius/U.S. 2/ & 0.86 & 0.74 \\
\hline
\end{tabular}

Sources: U.S.: Davis, et. al. , 2001, Job Creation and Job Destruction, 1997, MIT Press. Portugal: Blanchard, O. and P. Portugal, "What Hides Behind the Unemployment Rate," American Economic Review, (March); Central Stastistical Office, National Accounts of Mauritius; and staff estimates.

1/ Compared with U.S. manufacturing sector.

2/ Compared with U.S. apparel and textile ssectors.

64. The solution of this stylized model may be represented in a diagram. The endogenous equilibrium creation and destruction decisions can be neatly summarized by two elements: the reservation productivity, below which the match is destroyed $\left(\varepsilon_{d}\right)$; and the extent of labor market tightness - defined as the ratio of vacancies to the number of unemployed ( $\frac{v}{u}$ ). The equilibrium decisions relating to job creation (JC) and destruction (JD) can then be summarized in Figure III.5, which represent feasible combinations of $\varepsilon_{d}$ and $\frac{v}{u}$ that are consistent with the optimal creation and destruction of jobs. The negative relation between the "decision rules" that underlie the $\mathrm{JC}$ relation results from an increase in the tightness of the labor market leading to an increase in the expected cost of creating a new job - by reducing the chance a vacant position will be filled during this period - meaning that existing jobs will be more durable, and therefore less productive jobs will survive. When the wage is set by the government, rather than at the firm level, the reservation productivity 
underlying the amount of job destruction is independent of the tightness of the labor market, and hence results in a vertical JD curve. ${ }^{17}$

\section{The simple nature of this stylized model means that the impact of policies and} institutions can easily be studied. For the questions considered in this section, two comparative statics are relevant: (i) the impact of an exogenous compression in the wages relative to the results of bargaining; and (ii) the impact of limits on the ability to redeploy workers.

\section{The qualitative impact of wage compression on the creation and destruction} decisions of firms is clearly shown in Figure III.5(a). First, raising the average wage paid to low-skill workers, especially the wages of the lowest paid, makes the most "marginal" jobs unprofitable, resulting in their destruction. Therefore, the productivity of the marginal job, $\varepsilon_{d}$, must rise, increasing the total amount of destruction (the JD curve moves right). There is a slightly off-setting effect on job creation. Since all new jobs are assumed to begin with high productivity in this model, and as relative wage compression reduces the relative wage paid in higher wage jobs, the incentive to create new jobs (at the same time as destroy old jobs) rises slightly (the JC curve moves right). In aggregate, more jobs are destroyed, and fewer jobs are typically created.

Figure III.5. The Impact of Labor Market Institutions

(a) Wage Compression

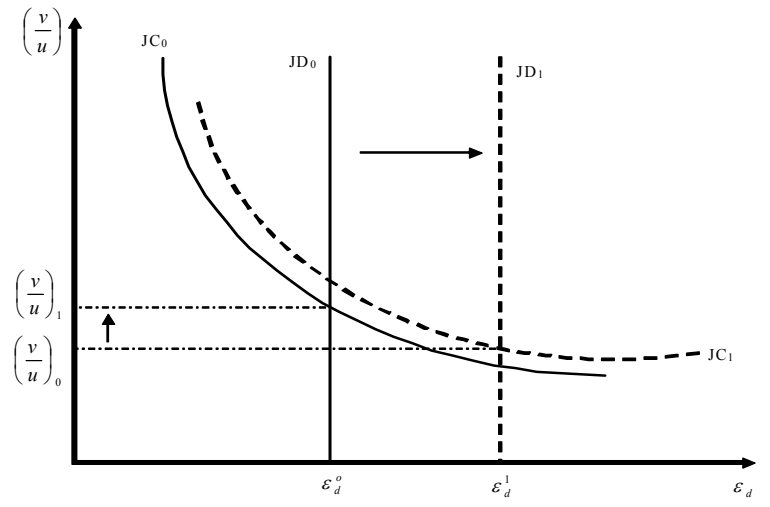

(b) Redeployment Restrictions

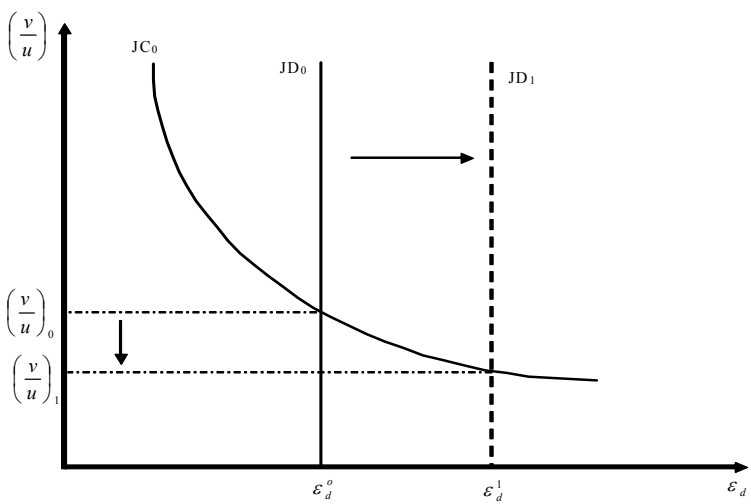

${ }^{17}$ This differs from the solution in the standard Mortensen and Pissarides (1994) model where wages are bargained. In that model, there is a negative relation underlying the JD curve, which reflects that a tighter labor market (higher $\frac{v}{u}$ ) increases workers' bargaining power - and hence their wages - meaning that more marginal jobs will become unprofitable and hence will be destroyed. 
67. The impact of restrictions on the flexibility of workers have very intuitive effects, which are shown in Figure III.5(b). ${ }^{18}$ By reducing the expected output of a worker in any given period, keeping workers in the more marginal jobs is no longer profitable (and so the JD curve moves right). Reflecting the increasing fragility of jobs, the destruction of jobs increases, as does the creation of new jobs.

68. These effects are quite general and apply beyond the EPZ sector. In particular, even if some sectors are granted a preferential regulatory environment, the opportunities for low-skill workers will still be unnecessarily restricted. Indeed, as the structure of the economy and the demand for low-skill workers changes over the coming years, the differential regulatory treatment could become increasingly detrimental.

69. To make this analysis more concrete, this stylized model of job creation and destruction is calibrated to salient features of the Mauritian economy. In particular, the model is calibrated to match the average EPZ job destruction rate following the establishment of the sector (1989-2002), and the unemployment rate for low-skill workers recorded in the 2000 census (of 9.6 percent). ${ }^{19}$ Finally, the parameters are chosen so that a reasonable degree of labor market tightness would result in a decentralized bargaining market. The baseline results are reported in Table III.2. While Mauritius's labor market institutions undoubtedly compress wages, there is unfortunately no concrete measure of the degree of this compression. ${ }^{20}$ Therefore, in this baseline calibration, we assume a small amount of "bleeding" of wages from high-wage sectors to low-wage workers (i.e., average low-skill wages are about 2 percent higher than what they would be under decentralized wage bargaining), as well as some moderate compression of wages paid within low-skill industries consistent with the cross-market effect.

70. Even with these minimal assumptions, there is a noticeable impact on unemployment, the average length of an unemployment spell, and-although to a lesser extent - unit labor costs. All of the policy experiments are performed relative to an environment where firm-level wage bargaining is the norm. Table III.2 reveals a significant increase in unemployment, as well as the average length of unemployment spells. These changes reflect a significant reduction in the creation of new jobs-evidenced by the 17 per-

${ }^{18}$ Since the ability of firms to redeploy workers reduces the value a firm can expect from a worker in any period, it is modeled as a reduction in the level of output expected in any period. That is, with some probability a worker may need to perform the duties of another occupational category. Since employment restrictions inhibit this redeployment, the worker is less valuable.

${ }^{19}$ It is implicitly assumed that all low-skill jobs share the job destruction rate of the EPZ sector. In 2000 the overall unemployment rate was 8.8 percent.

${ }^{20}$ For example, Mauritius does not have estimates of traditional measures of wage dispersion, such as the 90-10 wage differential, or the cross-sectional variance of wages paid. 
cent fall in the job finding rate - and an increase in job fragility — seen in the rate of job destruction. Even small amounts of wage compression can, therefore, lead to a significant reduction in the welfare of workers (and employers). A move to firm-level wage bargaining could bring significant benefits to these workers. While wage compression also tends to increase unit labor costs, it has a relatively minor impact because wage compression leads to the closure of the less productive jobs, raising average productivity.

Table III.2. Model Output: The Impact of Labor Market Restrictions

\begin{tabular}{|c|c|c|c|c|c|c|}
\hline & $\begin{array}{c}\text { Unemployment } \\
\text { Rate }\end{array}$ & $\begin{array}{l}\text { Unemployment } \\
\text { Duration (mths) }\end{array}$ & $\begin{array}{c}\text { Job Finding } \\
\text { Rate }\end{array}$ & $\begin{array}{c}\text { Job Destruction } \\
\text { Rate }\end{array}$ & $\begin{array}{l}\text { Unit Labor } \\
\text { Costs }\end{array}$ & $\begin{array}{l}\text { Excess Job } \\
\text { Reallocation }\end{array}$ \\
\hline \multicolumn{7}{|l|}{ No Wage Compression } \\
\hline Benchmark & 7.4 & 9.5 & 45.4 & 3.6 & 0.88 & 7.2 \\
\hline \multicolumn{7}{|l|}{ Wage Compression } \\
\hline Benchmark & 9.6 & 11.5 & 37.8 & 4.0 & 0.89 & 8.0 \\
\hline Percent Difference & 30.2 & 20.2 & -16.8 & 11.0 & 0.6 & 11.0 \\
\hline \multicolumn{7}{|l|}{ No Cross-Market } \\
\hline Compression & 7.7 & 9.3 & 46.7 & 3.9 & 0.87 & 7.8 \\
\hline Percent Difference & 4.3 & -2.7 & 2.8 & 7.7 & -1.0 & 7.7 \\
\hline \multicolumn{7}{|l|}{ No Within-Market } \\
\hline Compression & 9.5 & 12.0 & 36.1 & 3.8 & 0.89 & 7.6 \\
\hline Percent Difference & 28.6 & 25.7 & -20.4 & 4.7 & 1.0 & 4.7 \\
\hline \multicolumn{7}{|l|}{ Redeployment Restrictions } \\
\hline \multicolumn{7}{|l|}{ No Compression } \\
\hline redeployment rate & 7.7 & 9.9 & 43.8 & 3.7 & 0.88 & 7.3 \\
\hline Percent Difference benchmark & 4.1 & 3.7 & -3.5 & 0.8 & -0.5 & 0.7 \\
\hline \multicolumn{7}{|l|}{ Compression } \\
\hline 10 percent lower redeployment rate & 9.9 & 11.8 & 36.7 & 4.0 & 0.88 & 8.1 \\
\hline \multicolumn{7}{|l|}{ Percent Difference } \\
\hline Benchmark & 34.2 & 23.7 & -19.2 & 11.6 & 0.1 & 11.6 \\
\hline \multicolumn{7}{|l|}{ Percent Difference no } \\
\hline Compression & 29.0 & 19.4 & -16.2 & 10.7 & 0.6 & 10.8 \\
\hline
\end{tabular}

71. While both types of wage compression are costly, cross-market compression seems more harmful. Removing the cross-market compression leads to a much larger reduction in unemployment, than removing the within-market compression. Reflecting its immediate effect on profitability, removing the cross-market compression leads to a big increase in the rate of job creation, and a small reduction in the job destruction. Removing the assumed amount of within-market compression has a smaller effect on the creation of new jobs, but leads to a bigger fall in the fragility of existing jobs as it has a bigger impact on the profitability of the most marginal jobs.

72. A small reduction in the ability of firms to redeploy workers also leads to an increase in unemployment, and the length of average unemployment spells. In this exercise it is assumed that such regulations result in a 10 percent reduction in the level of output. The increases in unemployment and unemployment duration reflect increases in the 
fragility of jobs (an increase in job destruction), as well as a lower job finding rate given the fall in profitability. Table III. 2 also shows that wage compression significantly worsens the impact of these employment restrictions, with these restrictions resulting in a 4.1 percent rise in unemployment in the absence of wage setting restrictions, and a 34.2 percent rise in unemployment with such restrictions.

\section{Figures III.6-III.8 show the consequences of various degrees of wage} compression and employment restrictions for labor market outcomes, as we move from an undistorted equilibrium in which firms and workers are free to bargain over wages. Figure III. 6 shows the impact of cross-market compression up to a 5 percent increase in average wages. Figure III.7 shows the impact of increasing within-market wage compression, so that average wages remain relatively unchanged. Figure III.8 shows the effect of reducing the difficulty of redeploying workers, as reflected in an increase in expected output.

- Increases in the extent of cross-market wage compression lead to monotonic increases in unemployment and the fragility of jobs. Although not shown, they also increase the length of the average unemployment spell and the extent of inefficient churning.

- Increases in the extent of within-market wage compression tend to increase unemployment and the fragility of jobs. There is also an increase in the extent of inefficient churning, and the average duration of each job falls by over 10 percent. For very high amounts of wage compression, there is a slight reduction in unemployment reflecting the fact that-given the assumption that new jobs are created with the highest level of productivity - higher within-market wages tend to increase the job-finding rate.

- Increases in the ability to redeploy workers significantly reduce unemployment and job fragility. Although not shown, the average length of unemployment spells and the extent of inefficient churning also fall. Moreover, all these improvements are greater when wages are not compressed.

74. Wage compression significantly worsens the impact of negative shocks. As can be seen from Table III.2, the impact of a 10 percent reduction in the level of output significantly increases the extent of unemployment and the length of unemployment spells. With the main employers of low-skill workers undergoing significant changes in coming years, reform to these wage setting institutions will become increasingly important.

\section{Conclusion}

75. Sectors that intensively employ low-skilled workers, such as sugar and EPZ, have contributed significantly to the Mauritian "growth miracle" (Subramanian and Roy, 2001). The rapid economic transformation that resulted from the EPZ sector creation is clearly seen in Figures III.1 and III.2. However, in the face of impending changes in these markets, lowskill workers will face very different employment prospects in the coming years. 
Figure III.6: Cross-Market Wage Compression: Unemployment and Job Destruction

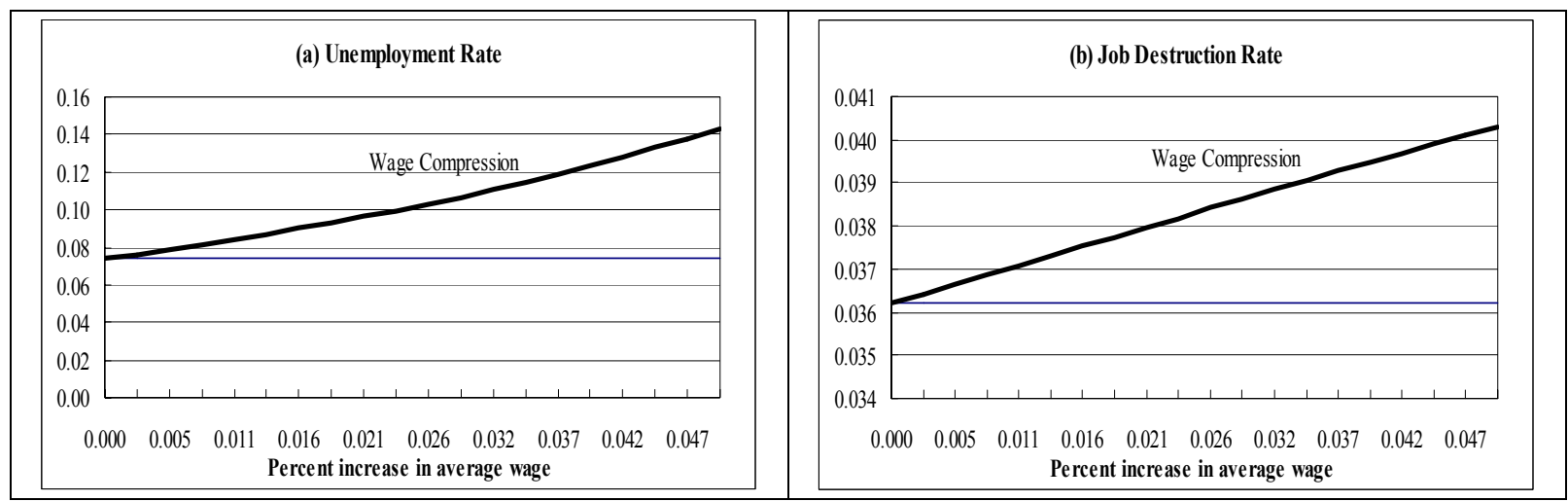

Figure III.7: Within-Market Wage Compression: Unemployment and Job Destruction

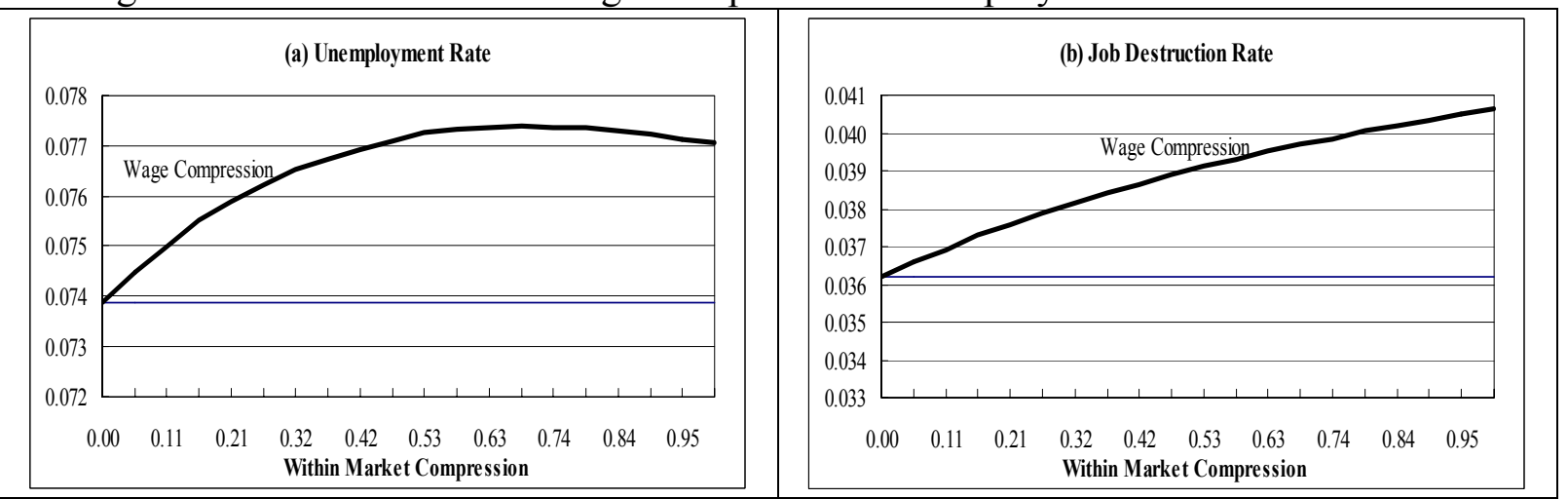

Figure III.8: Worker Redeployment: Unemployment and Job Destruction

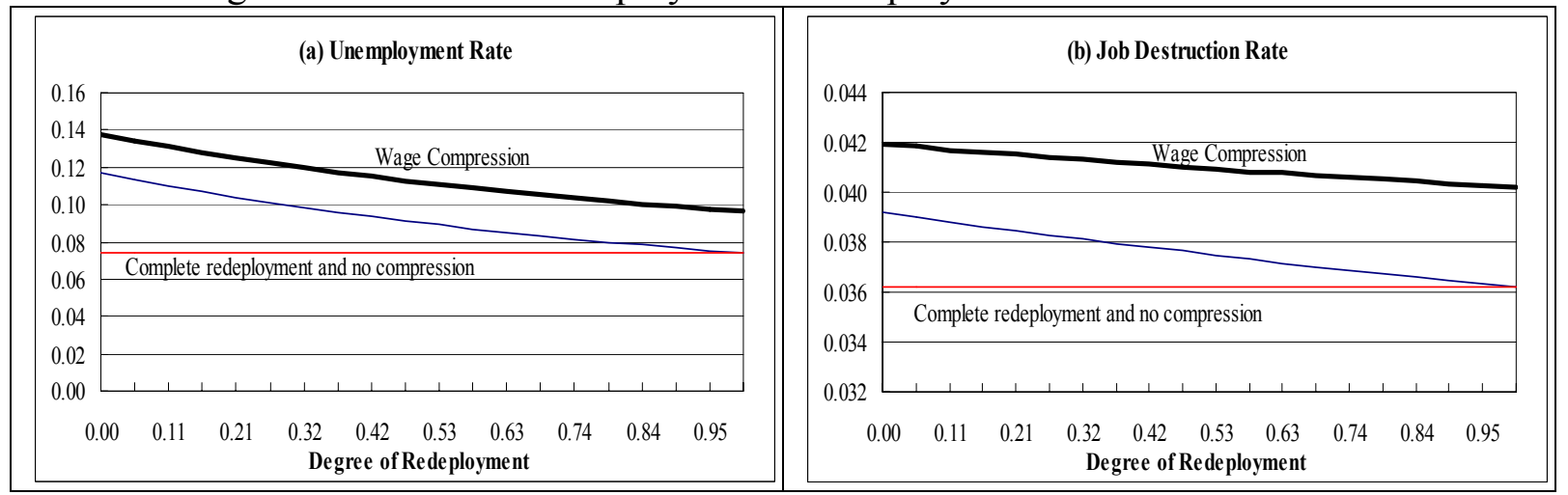

Indeed, the evidence presented in Section B suggests these changes, at least for textile workers, have already begun. Therefore, the need for labor market reform is now urgent.

76. While several factors have contributed to the incidence of unemployment in Mauritius, the results of a simple modeling exercise show that wage compression and redeployment restrictions reduce the employment of the affected workers and increase the length of the resulting unemployment spells. Moreover, all of these policies result in 
excessive turnover in the economy, which will ultimately reduce the ability of workers to acquire skills when employed and hasten their atrophy when workers become unemployed. Indeed, the harm resulting from any of these distortions is intensified when other distortions coexist. Moreover, wage compression imposes costs beyond those discussed in this paper. As Haltiwanger and Vodopivec (2002, p. 5) find in their study on Slovenia, “... businesses with more compressed wages have ... greater excess turnover for high quality workers, ... [and] wage compression creates excessive instability of jobs and imposes additional worker dislocation costs, as well as reduces firms' ability to achieve quality firm-worker matches."

77. Shielding some sectors from restrictive institutions may ameliorate the effects temporarily, but ultimately these distortions will harm the opportunities for low-skill workers and, more broadly, longer-term growth prospects. By distorting the incentives to reallocate economic activity into new, unimagined areas, these institutions limit the opportunities for low-skill workers and inhibit the reshaping of the economy. This will become increasingly so, as the economy undergoes an enforced structural transformation in the coming years.

78. While the government has embarked on a bold and essential series of educational reforms, general labor market reform remains crucial. These educational reforms will undoubtedly help Mauritius move into other high-tech fields, but will not be able to assist all low-skill workers. First, these educational reforms will take some time to bear fruit. Second, with only 7.3 percent of Mauritians having their higher school certificate, it will take considerable time before these new endeavors can absorb much of Mauritius's low-skilled labor force. Therefore, educational reform can, at most, be only a partial solution to the unemployment problem.

\section{Appendix}

The model is populated with entrepreneurs, who are able to create jobs. In this paper we assume that entrepreneurs can choose ex ante to search for either a domestic low-skill worker, or separately for a foreign worker. This, in effect, segments the low-skilled labor market into two separate markets, meaning that the analytical structure is applicable to both, and the markets may be considered separately. An entrepreneur will attempt to create a job by posting a vacancy whenever it is profitable to do so, meaning that the equilibrium number of vacancies posted is determined by a zero profit condition

$$
-k+\beta q\left(\frac{v}{u}\right) J(\bar{\varepsilon})=0
$$

where $k$ is the cost of posting the vacancy, $q($.$) is the rate at which entrepreneurs meet$ searching workers, $\beta$ is the discount factor, and $J(\varepsilon)$ is the value received by the entrepreneur from being matched with a worker. As mentioned in the text, these jobs are subject to idiosyncratic uncertainty, captured by the shock $\varepsilon$, which makes its value change. However, all new matches begin with the highest value of $\bar{\varepsilon}$. The value of each match must satisfy the following Bellman equation:

$$
J(\varepsilon)=f(\varepsilon)-w(\varepsilon)+\beta(1-\gamma) J(\varepsilon)+\beta \gamma E \max \left\{J\left(\varepsilon^{\prime}\right), 0\right\},
$$


where $f(\varepsilon)$ is the output generated by the match, $w(\varepsilon)$ is the negotiated wage, and $\gamma$ is the probability that the job will be subject to a change in its output. If the value of continuing with the worker in this current position falls below zero, the match is destroyed. The shock, $\varepsilon$, is drawn from a distribution, $F(\varepsilon)$. Although somewhat nonstandard, the process for idiosyncratic productivity defines a persistent stochastic process.

The value of working for an employed worker is given by an analogous Bellman equation to (A2)

$$
V^{e}(\varepsilon)=w(\varepsilon)+\beta(1-\gamma) V^{e}(\varepsilon)+\beta \gamma E \max \left\{V^{e}\left(\varepsilon^{\prime}\right), 0\right\},
$$

where the Emax operator reflects the fact that the wage bargain means that the worker and entrepreneur agree on the whether the match should continue. An unemployed worker generates a value that reflects the value that accrues to forming a match with an entrepreneur

$$
V^{u}=\beta\left[p\left(\frac{v}{u}\right) V^{e}(\varepsilon)+\left(1-p\left(\frac{v}{u}\right)\right) V^{u}\right],
$$

where $p($.$) is the probability that an unemployed worker receives a job offer.$

The costly and time consuming matching process is assumed to be represented in a very stylized way, with the number of matches formed in any period being a function of the number of vacancies and unemployed workers, $m(u, v)$. As is common, we assume this is a constant returns-to-scale function, meaning the job- and worker-finding rates only depend on the tightness of the labor market. Given all of this, the finding rates can be represented by:

$$
p\left(\frac{v}{u}\right)=\frac{m(u, v)}{u} \text {, and } q\left(\frac{v}{u}\right)=\frac{m(u, v)}{v} \text {. }
$$

The bargain process is assumed to satisfy the Nash axiomatic solution, meaning that wages paid must be sufficient so that workers receive their value for searching, plus a share (equal to their bargaining power, $\theta$ ) of the "surplus" generated by the match, i.e., $V^{e}(\varepsilon)=V^{u}+\theta S(\varepsilon)=V^{u}+\theta\left[J(\varepsilon)+V^{e}(\varepsilon)-V^{u}\right]$. Using these conditions, one can derive the conditions for job creation and destruction in the case that wages are determined by decentralized bargaining, with the equilibrium resembling that in Figure 5, except that the JD relation is upward sloping (Mortensen and Pissarides, 1994). Hosios (1990) shows that, given the matching frictions, only when the elasticity of the matching function with respect to vacancies equals $\theta$ is the equilibrium efficient. The equilibrium creation and destruction decision rules $\left(\frac{v^{*}}{u}\right.$ and $\left.\varepsilon_{d}\right)$ satisfy (A3) and (A4),

$$
q\left(\frac{v^{*}}{u}\right)=\frac{k}{\beta(1-\theta) S(\bar{\varepsilon})}, \text { and }
$$
respectively.

$$
S\left(\varepsilon_{d}\right)=f+\varepsilon_{d}+\beta(1-\gamma) S\left(\varepsilon_{d}\right)+\beta \gamma E \max \left\{S\left(\varepsilon^{\prime}\right), 0\right\}-\beta p \theta S(\bar{\varepsilon})=0,
$$


In the case where the government imposes a wage schedule that is not bargained, $\widetilde{w}(\varepsilon),(\mathrm{A} 2)$ is modified to become

$$
\widetilde{J}(\varepsilon)=f(\varepsilon)-\widetilde{w}(\varepsilon)+\beta(1-\gamma) \widetilde{J}(\varepsilon)+\beta \gamma E \max \left\{\widetilde{J}\left(\varepsilon^{\prime}\right), 0\right\} .
$$

The resulting equilibrium creation and destruction decision rules, and the expressions underlying the JC and JD curves in Figure 5 are, therefore,

$$
\begin{gathered}
q\left(\frac{\widetilde{v}^{*}}{u}\right)=\frac{k}{\beta \widetilde{J}(\bar{\varepsilon})}, \text { and } \\
\widetilde{J}\left(\varepsilon_{d}\right)=f\left(\varepsilon_{d}\right)-\widetilde{w}\left(\varepsilon_{d}\right)+\beta(1-\gamma) \widetilde{J}\left(\varepsilon_{d}\right)+\beta \gamma E \max \left\{\widetilde{J}\left(\varepsilon^{\prime}\right), 0\right\}=0 \text {, respectively. }
\end{gathered}
$$

It is easy to show that for linear production functions, the equilibrium wage function $(w(\varepsilon))$ will be linear in productivity: $w(\varepsilon)=w_{0}+w_{1} \varepsilon$. The wage compression assumed in this paper assumes that, for a constant distribution of productivity across jobs, average wages grow by $g$ percent and the slope of the wage schedule becomes flatter by a factor $\phi(\phi=1$ means no within-market compression). This means that the assumed compressed wage schedule is $\widetilde{w}(\varepsilon)=\widetilde{w}_{0}+\widetilde{w}_{1} \varepsilon$, where $\widetilde{w}_{1}=\phi w_{1}$ and $\widetilde{w}_{0}(\varepsilon)=w_{0}(1+g)+w_{1}(1-\phi+g) E(w(\varepsilon))$. Using this and (A6) and (A7) and the fact that $\left.\frac{\partial \widetilde{w}(\varepsilon)}{\partial \phi}\right|_{\varepsilon=\varepsilon_{d}}<0$, one can show that $\left.\frac{\partial \varepsilon_{d}}{\partial \phi}\right|_{J D}<0$, and $\left.\frac{\partial \varepsilon_{d}}{\partial g}\right|_{J D}>0$. Similarly, $\left.\frac{\partial \varepsilon_{d}}{\partial \phi}\right|_{J C}<0$ and $\left.\frac{\partial \varepsilon_{d}}{\partial g}\right|_{J C}=0$, although job creation is affected in the latter case though the rise in job destruction. Finally, steady state unemployment is given by $u^{*}=\frac{\delta^{*}}{p(.)+\delta^{*}}$, where $\delta^{*}$ is the steady state measure of jobs endogenously destroyed.

\section{References}

Bertola, Giuseppe, and Richard Rogerson, 1997, "Institutions and Labor Reallocation," European Economic Review, Vol. 41, pp. 1147-71.

Blanchard, O., and P. Portugal, 2001, "What Lies Behind the Unemployment Rate: Comparing Portuguese and U.S. Labor Markets," American Economic Review, Vol. 91 (March), pp. 187-207.

Davis, Steven J., John C. Haltiwanger, and Scott Schuh, 1997, Job Creation and Destruction (Cambridge: MIT Press).

Haltiwanger, John C., and Milan Vodopivec, 2002, "Worker Flows, Job Flows and Firm Wage Policies: An Analysis of Slovenia," IZA Discussion Paper, No. 569 (September). 
Hosios, Arthur, J., 1990, "On the Efficiency of Matching and Related Models of Search and Unemployment," Review of Economic Studies, Vol. 57 (April), pp. 279-98.

Layard, Richard, Stephen Nickell, and Richard Jackman, 1991, Unemployment: Macroeconomic Performance and the Labour Market (New York: Oxford University Press).

McDonald, Calvin, and James Yao, 2003, "Mauritius: Unemployment and the Role of Institutions," IMF Working Paper 03/211 (Washington: International Monetary Fund).

Mortensen, Dale T., and Christopher A. Pissarides, 1994, "Job Creation and Job Destruction in the Theory of Unemployment," Review of Economic Studies, Vol. 61 (July), pp. 397-415.

Pissarides, Christopher A., 2000, Equilibrium Unemployment Theory (Cambridge: MIT Press, $2^{\text {nd }}$ ed.).

Subramanian, Arvind, and Devesh Roy, 2001, "Who Can Explain the Mauritian Miracle: Meade, Romer, Sachs, or Rodrick?,” IMF Working Paper 01/116 (Washington: International Monetary Fund). 


\section{Inflation TARgeting in SMall Open Economies: The CaSE OF MAURitius ${ }^{21}$}

\section{A. Introduction}

79. Along with remarkable economic growth and diversification, Mauritius has also achieved low and stable inflation. Inflation (year-on-year) fell from around 8 percent in mid-1996, when Mauritius introduced its current informal inflation targeting regime, to around 4 percent in the year to March 2004 (Figure IV.1). ${ }^{22}$ Over the same period, output growth was high - averaging more than 5 percent per year - at rates comparable with those of the former Asian tigers. Therefore, Mauritius's informal inflation targeting regime has, so far, been associated with a decline in inflation. Nonetheless, as this success has been won during a period of relatively subdued inflation worldwide, a true test of its inflation targeting regime will come if global inflation picks up in the future.

80. Mauritius's institutional environment suggests that inflation targeting could be successful there. Mauritius has a long tradition of strong independent public institutions, and although it has relatively high government debt (estimated at almost 60 per cent of GDP in 2003/04), it has moderate (and declining) external debt. ${ }^{23}$ The government has no history of extensively borrowing from the central bank, and is actively reducing its budget deficit. ${ }^{24}$ In addition, Mauritius has both a highly developed (on-shore and off-share) banking sector, as well as a primary dealer's network to facilitate the trade in treasury bills. Although the central bank is not technically independent, the government has maintained "arms-length" transactions with the bank. Moreover, its central statistical office produces good and timely macroeconomic data. These factors are important prerequisites for the central bank to establish the credibility required for inflation targeting. ${ }^{25}$

${ }^{21}$ Prepared by Nathan Porter and James Yao.

${ }^{22}$ An inflation rate of 3 to 5 percent sustained over time is generally accepted in Mauritius as low inflation.

${ }^{23}$ According to the 2003 reports of the World Economic Forum and Transparency International, Mauritius is among the top five African countries for quality of public institutions and perceptions of corruption.

${ }^{24}$ In fact, since 2002 the Bank of Mauritius (BOM) has been a net debtor of the government - that is, the government has maintained substantial (net) deposits with the BOM.

25 As such, Mauritius's institutional setting contains many of the institutional factors Mishkin (2004) regards as essential to the success of inflation targeting. 
Figure IV.1. Annual CPI Inflation

(In Percent)

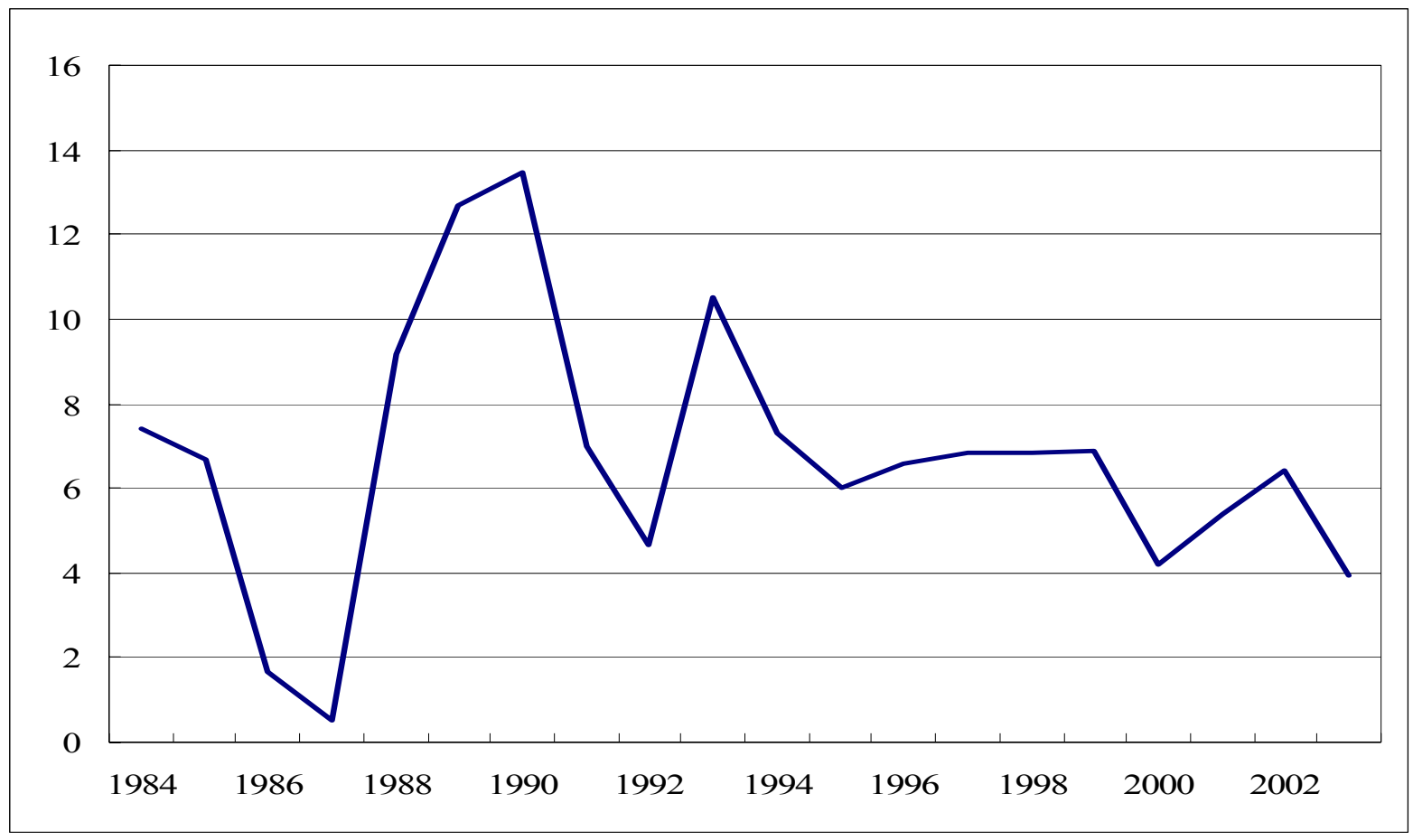

81. This paper investigates Mauritius's experience with inflation targeting and finds that inflation targeting has been associated with a fall in inflation, principally through the anchoring of expectations. A series of financial sector deregulation measures in the 1980s and 1990s set the stage for the Bank of Mauritius (BOM) to pursue informal inflation targeting, through a de facto public commitment to low (CPI) inflation in the mid-1990s. Interestingly, this informal inflation targeting occurred against the backdrop of a managed (although relatively flexible) exchange rate. While the BOM's informal inflation targeting seems to have been generally successful, it took the BOM some time to earn the credibility required to anchor lower inflationary expectations.

82. Mauritius's favorable experience jointly managing an informal inflation target and a managed exchange rate could provide a useful policy example for other small open island economies. In attempts to provide credible nominal anchors, many small island economies have chosen hard pegs (through dollarization, monetary union, currency boards, and fixed pegs without bands). However, hard pegs can easily reduce an economy's flexibility in the face of real and external shocks, running the risk of overvaluation, and possibly resulting in balance of payments difficulties. For example, the countries of the Eastern Caribbean Currency Union (ECCU) are facing balance of payments adjustment 
challenges in the context of trade liberalization and the loss of trade preferences. $^{26}$

Mauritius's experience provides a "practical" example of a small island economy-with strong institutions and a lack of fiscal dominance - that has controlled inflation by using inflation targeting as a nominal anchor.

83. Mauritius's experience may also provide an interesting case to compare with the recommendations of the theoretical literature on inflation targeting. Some studies have suggested that including the prices of tradables in an inflation target may lead to policy responses that generate large output volatility (Ball, 1999; Svensson, 2000; Dennis, 2001). ${ }^{27}$ Mauritius's successful targeting of aggregate CPI inflation suggests that these concerns may be overstated. Not only is aggregate CPI inflation a more transparent target than "domestic" inflation, Mauritius's experience suggests that by focusing expectations, successful inflation targeting may be able to influence the pace and extent of pass-through, thereby limiting the damage to the nontradables sector. ${ }^{28}$ Moreover, by conducting monetary policy (indirectly) through the interest rate, at the same time as managing the exchange rate, the BOM has effectively followed Ball's (1999) recommendation that small open economies should conduct policy through some form of Monetary Condition Index (MCI) (based on both the interest rate and the real exchange rate).

84. The methodology used to investigate the informal inflation targeting framework is based on a new open economy macrofinance model that combines a no-arbitrage finance specification of the term structure, with a standard open economy empirical macroeconomic model. This allows the explicit modeling of the yield curve in a way that permits interactions between the macro economy and bond yields. While this paper's framework is similar to that of Hördahl, Tristani, and Vestin (2003) and Rudebusch and Wu (2003), it is the first to extend the framework to a small open economy.

85. This approach has several strengths: (i) it exploits information on the maturity structure of interest rates, leading to a direct link between policy interest rates and the longerterm interest rates that influence real activity and inflation; (ii) it separates the effects of the level and slope of the yield curve on activity and inflation; and (iii) it provides a direct link between inflationary expectations and the target inflation rate. This last aspect is especially useful, since it allows an investigation of the degree to which inflationary expectations have been anchored over the inflation targeting period.

${ }^{26}$ ECCU countries consist of Antigua and Barbuda, Dominica, Grenada, St. Kitts and Nevis, St. Lucia, St. Vincent and the Grenadines.

${ }^{27}$ Subsequent, more micro-founded analysis, suggests similar considerations (Galí and Monacelli, 2003 and Parrado, 2004).

${ }^{28}$ Miskin (2004) also argues that successful inflation targeting can, through expectations formation, lessen the affect of exchange rate fluctuations on the economy. 
86. This paper is organized as follows: Section B describes the development of inflation targeting in Mauritius, including the main components of its inflation targeting framework. Section C introduces the macrofinance open economy model; Section D discusses the estimation of this model; while Section E describes the implicit behavior of inflationary expectations. Section F concludes.

\section{B. Development of Inflation Targeting}

\section{A brief history of monetary policy}

87. This section briefly describes the history of monetary policy implementation in Mauritius. The BOM was established as the central bank with the passage of the Bank of Mauritius Act in 1967. This enabled the BOM to act as the lender of last resort, as well as be the banker of the government. The powers of the BOM were further enhanced in 1971, when it was granted wide supervisory powers over banks, and given the authority to issue bank prudential regulations.

88. Prior to the 1990s, the BOM conducted monetary policy mainly through direct instruments, such as ceilings on commercial bank credit and administered interest rates. However, the financial reforms in the late 1980s brought some liberalization of exchange controls on both current and capital transactions. ${ }^{29}$ The liberalization of capital controls, and the establishment of an interbank foreign exchange market were completed in 1994. The basket-peg regime was replaced with a more flexible exchange regime, although limited intervention continued. Reflecting the emphasis of monetary policy on exchange rates during this period, annual inflation averaged close to 9 percent over the years between 1989 and 1993, and was also considerably volatile. Credit ceilings were also abolished in July 1993.

89. In line with the liberalization of the financial sector and exchange rate, the BOM reconsidered its monetary operations and objectives in the 1990s. The BOM began conducting monetary policy through open market operations - in weekly treasury bill auctions - from 1991. The gradual floating of the exchange rate that commenced in 1994, required the BOM to choose a new nominal anchor. As a result, in 1996 the BOM introduced informal inflation targeting, while maintaining its intervention in the foreign exchange market.

90. This liberalization has allowed Mauritius to develop a relatively large and comprehensive domestic financial system and a growing offshore sector. The domestic banking system is sound and profitable. The basic financial sector infrastructure, such as payment, securities trading and settlement systems, is modern and efficient. There is also a primary dealers network to facilitate the trade in government securities. However, the development of the corporate capital market has lagged behind that of the banking sector.

\footnotetext{
${ }^{29}$ Mauritius accepted the obligations of Article VIII of the Articles of Agreement of the International Monetary Fund in 1993.
} 


\section{Inflation targeting framework}

91. Mauritius's informal inflation targeting regime encompasses five main elements: (1) the public announcement of an annual target for aggregate inflation (CPI inflation) instead of nontradable inflation; (2) an express commitment to price stability as the primary goal of monetary policy; (3) an integrated operational strategy in which many variables, including foreign exchange intervention, are used to set the monetary policy instruments, while maintaining the managed float of the exchange rate regime; (4) a flexible monetary policy rule in which interest rate smoothing, inflation expectation, real exchange rate and output gap are included; and (5) transparent monetary policy operations. Therefore, although its inflation targeting regime is "informal," its regime encompasses the main elements required for formal inflation targeting (Mishkin, 2004).

\section{Public announcement of aggregate inflation targets}

92. The BOM began announcing an aggregate inflation target in its 1996/97 (JuneJuly) annual report. The BOM pursued a very gradual approach to lowering its inflation objectives. It began with targets of over 8 percent for 1996/97, and gradually lowered them to 4 percent - see Table IV.1. This gradualist strategy allowed the BOM to establish solid credibility in managing inflation by allowing the public to observe the achievement of a sequence of realistic targets. However, the BOM mainly gets its annual inflation target based on the available inflation expectation information. For example, the BOM increased its target from 6 percent in 1997/98 to 8 percent in 1998/99, so that it can accommodate the strong inflation expectation at that time and therefore preserve the credibility of inflation targeting.

Table IV.1. CPI Inflation Targets and Outcomes

\begin{tabular}{lllllllll}
\hline & $1996 / 97$ & $1997 / 98$ & $1998 / 99$ & $1999 / 00$ & $2000 / 01$ & $2001 / 02$ & $2002 / 03$ & $2003 / 04$ \\
\hline $\begin{array}{l}\text { Target } \\
\text { inflation }\end{array}$ & 8.0 & 6.0 & 8.0 & 6.0 & $5.0-5.5$ & 6.0 & 6.0 & 4.0 \\
$\begin{array}{l}\text { Actual } \\
\text { inflation }\end{array}$ & 7.9 & 5.4 & 7.9 & 5.3 & 4.4 & 6.3 & 5.1 & 4.0 \\
\hline
\end{tabular}

\section{De facto commitment to price stability}

93. The original Bank of Mauritius Act established the BOM to "safeguard the internal and external value of the currency of Mauritius and its internal convertibility," and to "direct its policy toward achieving monetary conditions conducive to strengthening the economic activity and prosperity of Mauritius." The 1988 amendment of this Act granted the BOM the responsibility for the formulation and execution of monetary policy consistent with price stability. Even though price stability was not established as the BOM's overriding objective, the BOM has increasingly focused on this objective, and has declared its commitment to achieving this goal since 1996. In a number of speeches, the governor of the BOM has made it clear that price stability is the primary goal of the BOM. Nonetheless, the BOM also remains concerned about economic growth and competitiveness of the economy. 


\section{An integrated operational strategy}

94. As in many emerging market countries, Mauritius's secondary government bond market is relatively illiquid and underdeveloped. Therefore, the BOM cannot easily target short-term interest rates directly through open market operations in this market. As an alternative, the BOM has used a mix of integrated policy instruments to target short-term interest rates indirectly, including through the primary government bond market. Underlying its choice of settings for these instruments is the BOM's detailed and information-inclusive reserve money program. The BOM publicly announced the existence of its reserve money program for liquidity management and forecasting purposes in 1996. The main objective of this is to maintain the monetary base on a path consistent with the BOM's inflation target, and the Central Statistical Office's economic growth forecast. However, as the BOM has found it difficult to achieve its reserve money target, it has never announced its reserve money and associated M2 targets.

\section{Open market operations}

95. The BOM has increasingly relied on short-term interest rates as its operational target, despite maintaining the reserve money target as a complementary operational target. In the primary government bond market, treasury (or, more recently, the BOM) bills of 3-, 6-, 12- and 24-month maturities are sold at weekly auctions. ${ }^{30}$ This has tended to produce fairly stable yield curves, with the resulting price discovery likely to be relatively efficient. These auctions have been used to implement the reserve money program. ${ }^{31}$

- $\quad$ The BOM varies its sales of treasury and BOM bills in the primary market auction in order to influence the level of liquid reserves held by commercial banks. While the amount of treasury bills sold at the weekly auction is guided by the reserve money program, the interest rates resulting from these auctions have been used as an indicator of the stance of monetary policy.

- $\quad$ Repurchase transactions (repo) and reverse repo operations have also been used periodically since 1999 for fine tuning, complementing the primary auction of treasury bills.

- $\quad$ The BOM's secondary market cell (a portfolio of treasury bills) is occasionally employed in secondary market trading, allowing market participants to adjust their liquidity between the weekly primary auctions.

\footnotetext{
${ }^{30}$ The Development Loan Stock with maturities up to 15 years are issued annually, while five-year bonds are issued quarterly.

${ }^{31}$ From July 2003, the BOM began to issue its own central bank bills.
} 


\section{The signaling role of interest rates}

96. As the lender of last resort, the BOM provides a Lombard facility where banks can borrow overnight to meet reserve requirements. The BOM mainly uses the Lombard rate to signal the stance of monetary policy, since the market generally seems to have adjusted its rates in line with movements in the Lombard rate in the past. However, with the money market rate currently much lower than the Lombard rate, this facility has not been used extensively in recent times.

\section{Foreign exchange intervention}

97. The BOM has gradually reduced its foreign exchange intervention, and has always denied any predetermined target path for the real exchange rate. For example, the BOM's 2002 Annual Report only specifies that it aims at "reflecting the macroeconomic fundamentals of the country" (statement of the Governor, page 7), although the level of the real exchange rate has remained roughly unchanged throughout the inflation targeting period-see Figure IV.2. To keep its foreign exchange market interventions consistent with its inflation target, the BOM integrates its foreign exchange market interventions into its open market operations through its reserve money program. However, as its inflation targeting regime has increasingly gained credibility, the BOM has tended to reduce its intervention in the foreign exchange market - see Table IV.2. This reduction should further strengthen the BOM's credibility in anchoring aggregate inflation expectation. However, given Mauritius's very thin foreign exchange market, some intervention may remain necessary to smooth volatility.

Table IV.2. Bank of Mauritius Foreign Exchange Market Intervention, 1996/97-2003/04

(In millions of U.S. dollars).

\begin{tabular}{lllllllll}
\hline & $1996 / 97$ & $1997 / 98$ & $1998 / 99$ & $1999 / 00$ & $2000 / 01$ & $2001 / 02$ & $2002 / 03$ & $2003 / 04$ \\
\hline Sale & 392.1 & 252.4 & 126.6 & 94.0 & 118.3 & 19.0 & 0 & 0 \\
Purchase & 38.9 & 37.0 & 11.0 & 15.7 & 0 & 21.1 & 189.0 & 68.0 \\
\hline
\end{tabular}

Source: Bank of Mauritius Annual Reports. 
Figure IV.2. Nominal and Real Effective Exchange Rates

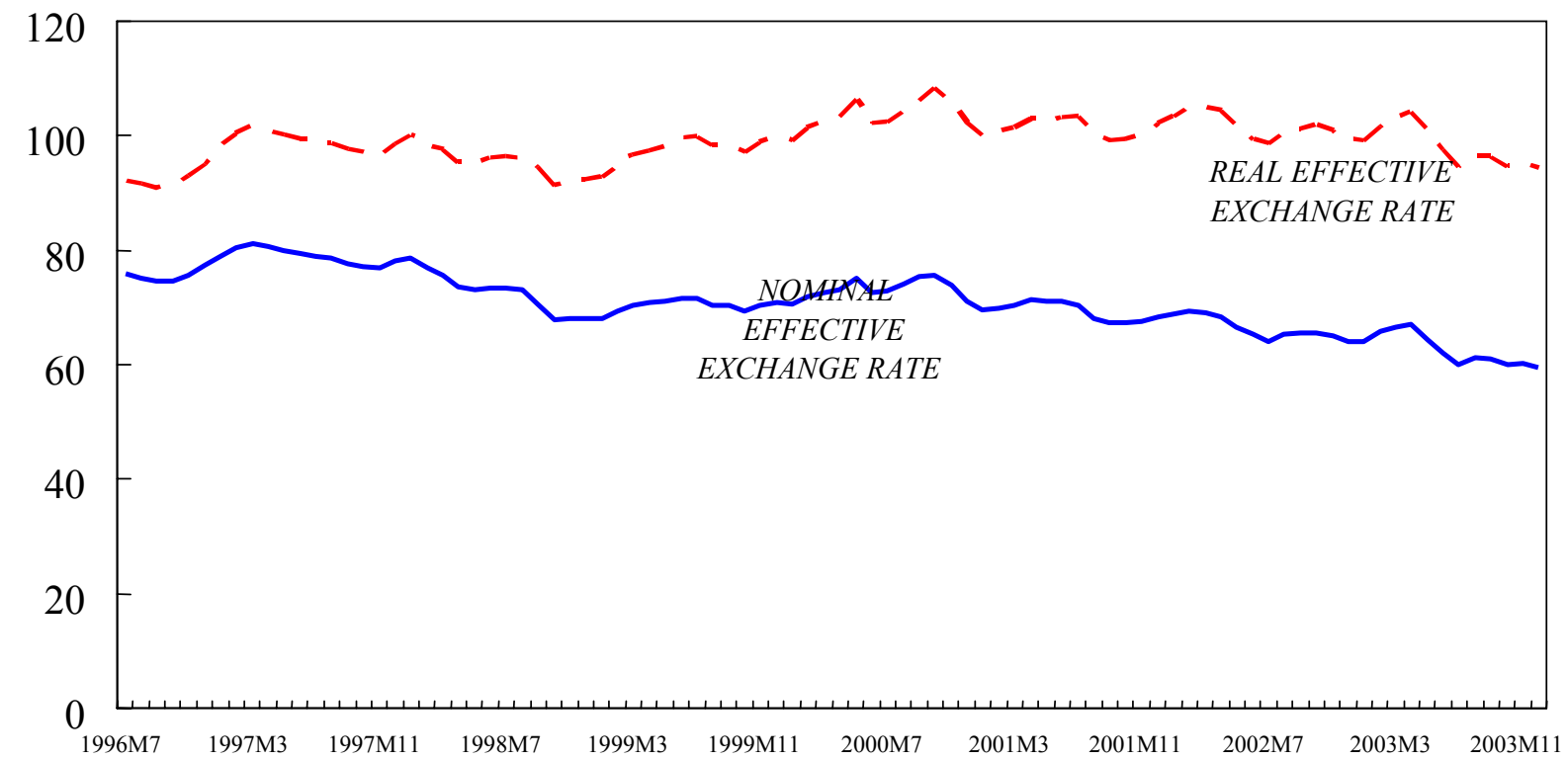

\section{A flexible monetary policy rule}

98. The main focus of the BOM's implicit monetary policy rule is targeting inflationary expectations. However, the BOM clearly places some weight on the exchange rate. The 2001 BOM Annual Report stated that "the basic thrust of monetary policy continued to be directed toward the achievement of low inflation and a stable exchange rate" (statement from the Governor, page 6). This makes its rule similar to Ball's (1999) MCIbased on both the interest rate and the exchange rate. In addition, current inflation and output (gap) also influence policy (and the setting of the MCI) through the reserve money program.

\section{Transparent monetary policy operations}

99. The transparent operation of monetary policy has benefited from frequent consultations between the BOM and commercial banks, as well as public statements by its Governor. Commercial banks seem generally satisfied with their frequent dialogue with the BOM. The BOM also maintains an informative website, publishes a comprehensive annual report and a comprehensive monthly statistical monetary bulletin, and has a relatively open policy towards, the media. The introduction of the Lombard facility, and the framework for repurchase and reverse repurchase transactions, were designed to increase transparency further. 


\section{An Open Economy Macrofinance Model}

100. This section formally investigates the informal inflation targeting framework described above. To do this, a macrofinance model (similar to that of Hördahl, Tristani, and Vestin (2003), and Rudebusch and Wu (2003)), is combined with an empirical open economy model (similar to that of Svensson, 2000). This model integrates open economy macroeconomic and financial models, combining an affine model of the term structure (which imposes no-arbitrage constraints), with an open economy, new Keynesian model, where monetary policy is represented by a simple interest rate rule. By using the yield curve to extract inflation expectations, new information can be brought to bear on the performance of inflation targeting.

101. A relatively standard new-Keynesian representation of aggregate demand in an open economy is of the form: ${ }^{32}$

$$
\left.y_{t}=\mu_{y} E_{t} y_{t+1}+\left(1-\mu_{y}\right) \mid \beta_{y_{1}} y_{t-1}+\beta_{y 2} y_{t-2}\right\rfloor+\beta_{q y} q_{t-1}-\beta_{r}\left(i_{t-1}-L_{t-1}\right)+\varepsilon_{y t}
$$

where $y_{t}$ is output gap, $E_{t} y_{t+1}$ is the expected output gap at time $\mathrm{t}, q_{t}$ is real exchange rate, $i_{t}$ is the short-term interest rate, and $\varepsilon_{y t} \sim N\left(0, \sigma_{y}\right)$ represents real demand shocks. The latent factor, $L_{t}$, represents the level of yield curves and is typically interpreted as the underlying rate of inflation (see Rudebusch and $\mathrm{Wu}, 2003$ ). Consistent with this interpretation, $L_{t}$ may be viewed as the inflation rate targeted by the central bank, and, ultimately, as the inflation rate expected by private agents. These expectations play a very important role in the context of Mauritius's annual centralized wage determination system, since they provide a focal point for the behavior of wage- and price-setters. ${ }^{33}$ A depreciation of the real exchange rate also leads to an expansion in output with a lag, through its effects on net exports. The parameter $\mu_{y}$ measures the relative importance of the expected future output gap.

102. Agents are assumed to gradually modify their views about inflationary expectations, as represented by $L_{t}$, with actual inflation according to

$$
L_{t}=\rho_{L} L_{t-1}+\left(1-\rho_{L}\right) \pi_{t}+\varepsilon_{L t},
$$

where $\rho_{L}$ is the relative weight between the past inflation expectation to the actual inflation, and $\varepsilon_{L t} \sim N\left(0, \sigma_{L}\right)$ represents other nonsystematic influences on expectations formation.

\footnotetext{
${ }^{32}$ Micro-founded small open economy models produce a similar expression for the output gap (Galí and Monacelli, 2003; Parrado, 2004).

${ }^{33}$ Under Mauritius's centralized tripartite wage setting mechanism, there is automatic acrossthe-board wage indexation for any inflation above 5 percent in a year.
} 
103. The open economy supply equation (Phillip's curve) is given by

$$
\pi_{t}=\mu_{\pi} L_{t}+\left(1-\mu_{\pi}\right)\left[\alpha_{\pi 1} \pi_{t-1}+\alpha_{\pi 2} \pi_{t-2}\right]+\alpha_{q} q_{t-1}+\alpha_{y} y_{t-1}+\varepsilon_{\pi t} \cdot{ }^{34}
$$

In this specification, current inflation, $\pi_{t}$, reflects a weighted average of the public's forward looking expectation of the inflation rate, which we identify as $L_{t}$, with backward looking expectations represented by two lags of inflation. A key parameter in (3) is $\mu_{\pi}$, which measures the relative importance of forward- versus backward-looking pricing behavior. The output gap, as well as changes in competitiveness, are also assumed to influence inflation. The innovation, $\varepsilon_{\pi t} \sim N\left(0, \sigma_{\pi}\right)$, represents stochastic cost-push factors.

104. Provided that the real interest parity condition holds, real effective exchange rate dynamics may be written as 35

$q_{t}=E_{t} q_{t+1}-\left(i_{t}-E_{t} \pi_{t+1}\right)+\varepsilon_{q t}$.

The current real exchange rate is determined by the expected future real exchange rate, $E_{t} q_{t+1}$, and the ex ante real interest rate $\left(i_{t}-E_{t} \pi_{t+1}\right)$. Assuming some inertia in the formation of real exchange rate expectations, we assume that the real exchange rate is given by

$q_{t}=E_{t} q_{t+1}+\beta_{q 1} q_{t-1}+\beta_{q 2} q_{t-2}-\beta_{q S}\left(i_{t}-L_{t}\right)+\varepsilon_{q t}$,

where $\beta_{q S}$ reflects transitional dynamics.

105. Due to the underdeveloped secondary government bond market, the BOM is not able to conduct high frequency open market operations to directly control the shortterm interest rate. However, this rate is determined by both the monetary policy of the BOM (which influences the slope of the yield curve), and the inflationary expectations of participants in the primary bond market. As discussed above, while the BOM uses several instruments, its operational target is the short-term interest rate. Therefore, we take the short term interest rate as the policy variable, and following Rudebusch and $\mathrm{Wu}$ (2003), we assume that behavior of this rate may be captured by two latent term structure factors, $L_{t}$ and $S_{t}$, in

$$
i_{t}=\delta_{0}+L_{t}+S_{t}
$$

One of these factors, $S_{t}$, represents the slope of the yield curve (i.e., the spread between the long-run interest rate and the short-run interest rate), while the other, $L_{t}$, represents the level

${ }^{34}$ Again, micro-founded small open economy models produce a simlar Phillips' curve, although for domestic inflation (Galí and Monacelli, 2003; Parrado, 2004).

35 This is similar to equation 2.11 in Svensson (2000). 
of the yield curve. If, as we do, one interprets $L_{t}$ as representing inflationary expectations, then $S_{t}$ can also be interpreted as the real interest rate. Finally, the specification of longerterm yields is determined assuming that they satisfy an affine no-arbitrage formulation. ${ }^{36}$

\section{The BOM's monetary policy rule is assumed to be similar to that recommended} by Ball (1999) for small open economies. It includes the output gap $y_{t}$, inflation expectation (as captured by $L_{t}$ ), the deviation between actual inflation and inflation expectation $\left(\pi_{t}-L_{t}\right)$, the real exchange rate $q_{t}$, as well as a desire to smooth the real interest rate:

$$
\begin{gathered}
i_{t}=L_{t}+\rho_{S}\left(i_{t-1}-L_{t-1}\right)+\left(1-\rho_{S}\right)\left[\gamma_{q} q_{t}+\gamma_{\pi}\left(\pi_{t}-L_{t}\right)+\gamma_{y} y_{t}\right\rfloor+u_{S t} \\
u_{S t}=\rho_{u} u_{S, t-1}+\varepsilon_{S, t} .
\end{gathered}
$$

Equation (7) has the nominal policy interest rate centered about inflationary expectations, and captures the various possible monetary policy objectives of the BOM: to stabilize the real economy; to maintain an appropriate real exchange rate; and to close the gap between actual inflation and its inflation target. It also allows for some persistence in the setting of this rate. Using (6), equation (7) may be easily expressed in terms of the slope factor $S_{t}$ as

$$
S_{t}=\rho_{S} S_{t-1}+\left(1-\rho_{S}\right)\left\lfloor\gamma_{q} q_{t}+\gamma_{\pi}\left(\pi_{t}-L_{t}\right)+\gamma_{y} y_{t}\right\rfloor+u_{S t}
$$

The parameter estimates of equation (9) should reveal the relative importance of each of these objectives to the BOM. In addition, the dynamics of $S_{t}$ allow for both partial adjustment, and (through (8)) serially correlated unanticipated monetary policy shocks. If $\rho_{S}=0$, the dynamics of $S_{t}$ arise from monetary policy partial adjustment. Conversely, if $\rho_{S} \neq 0$, the BOM's monetary policy choice exhibits persistence, and occurs in gradual adjustments. Using (1) and (6) we can obtain (1')

$$
y_{t}=\mu_{y} E_{t} y_{t+1}+\left(1-\mu_{y}\right)\left\lfloor\beta_{y_{1}} y_{t-1}+\beta_{y 2} y_{t-2}\right\rfloor-\beta_{r} S_{t-1}+\varepsilon_{y t}
$$

and using (5) and (6) we can obtain (5')

$q_{t}=E_{t} q_{t+1}+\beta_{q 1} q_{t-1}+\beta_{q 2} q_{t-2}-\beta_{q S} S_{t}+\varepsilon_{q t}$

\footnotetext{
${ }^{36}$ The affine no-arbitrage term structure model is presented in Appendix I. We also assume that the price of the risk associated with the factors underlying the term structure may be represented as $\Lambda_{t}=\lambda_{0}+\lambda_{1}\left[\begin{array}{l}L_{t} \\ S_{t}\end{array}\right]$. Since we use demeaned data in the following empirical exercise, we can, without loss of generality, normalize $\delta_{0}$ and $\lambda_{0}$ to zero.
} 
The dynamic structure of the transition for the state of the economy is determined by equations (1'), (2), (3), (5'), (8) and (9). The state space of the combined rational expectations open economy macrofinance model is outlined in Appendix I.

\section{Model Estimation}

107. The above macrofinance model is estimated by maximum likelihood for the informal inflation targeting period-July 1996 to March 2004. Monthly data on government bond yields (for 3-, 6-, and 12-month maturities) provided by the BOM, annualized CPI inflation from the IMF's International Financial Statistics, and the real exchange rate from the IMF's Information Notice System are used to estimate the model. Due to the unavailability of less than annual GDP (or even unemployment) data, we use detrended, seasonally adjusted, monthly credit to the private sector as a proxy for the output gap. ${ }^{37}$

108. Appendix II presents the parameter estimates of the open economy macrofinance model. First, consider the dynamics of the latent factors. The factor representing inflationary expectations, $L_{t}$, is extremely persistent with $\rho_{L}$ estimated at 0.9921 . This means that inflation expectations are very persistent, potentially difficult to change, with actual inflation carrying a very small weight in inflation expectation formation. In short, once a good reputation is established, it should last a long time.

109. The estimated BOM's monetary policy rule is

$$
\begin{gathered}
S_{t}=0.9958 S_{t-1}+0.0042\left[0.8172 q_{t}+0.3621\left(\pi_{t}-L_{t}\right)+0.0084 y_{t}\right]+u_{S t} \\
u_{S t}=1 \exp (-5) u_{S, t-1}+\varepsilon_{S, t} .
\end{gathered}
$$

Since the estimated $\rho_{S}=0.9958, S_{t}$ is also highly persistent. This seems reasonable in terms of the considerable inertia seen in the BOM's monetary policy setting, represented by its gradual reduction in targeted inflation. However, this also implies that the BOM has relatively weak control over the short-term interest rate $\left(\left(1-\rho_{S}\right)=0.0042\right.$. $)$, although this could be an artifact of the indirect nature of the BOM's interest rate targeting, and the relatively crude proxy for the output gap. The relative importance of the inflationary deviations, the output gap, and the real exchange rate are revealed by the estimates of $\gamma_{\pi}, \gamma_{q}$ and $\gamma_{y}-0.3621,0.8172$ and 0.0084 , respectively. These estimates suggest that multiple monetary policy objectives influence policy, implying a flexible rather than strict inflation

${ }^{37}$ Since the constant term in latent factor models cannot typically be identified, we work with de-meaned data. Also, as we are estimating two latent factors from three bond maturities, we assume that six-month bond yields are measured with error. 
targeting in Mauritius. Unfortunately, though, all of these parameters are very imprecisely estimated (possibly because $\rho_{S}$ is so large), with none actually being significant. There is also no autocorrelation in unanticipated monetary shocks, $u_{S t}\left(\right.$ as $\left.\rho_{u}=1 \exp (-5)\right)$.

110. The estimated parameters of the aggregate supply (Phillips curve) equation suggest that current inflation depends primarily (and weakly significantly) on inflationary expectations $\left(\mu_{\pi}=0.9110\right)$. This indicates the importance of framing expectations throughout the setting of monetary policy, and suggests that central bank credibility is crucial. Surprisingly, all other explanatory variables, including real exchange rate and output gap, are much less important than expectations, and are insignificant. However, the weak impact of the real exchange rate may reflect the past reliance on (inflexible) administered prices for several imported goods, as well as the crude proxy of the monthly output gap. The preeminent role of inflationary expectations in Mauritius is relatively unsurprising, though, given the important role these expectations play in the centralized wage-setting process.

111. The estimated parameters describing the aggregate demand equation suggest that, at a monthly frequency, there is a negligible weight on forward-looking output expectations $\left(\mu_{y}=0.0223\right)$. The estimated value of $\beta_{q y}=0.0004$ implies a very weak impact of real exchange rate changes on output. This could partially be explained by the relatively flat nature of the real exchange rate over the inflation targeting period.

\section{E. Dynamics of Inflation Expectation}

112. Figure IV.3 presents the latent factor that represents the level of the yield curve, $L_{t}$, as well as the slope, $S_{t}$. Two observations are immediate: (i) inflationary expectations in Mauritius are time-varying; and (ii) both the average level and volatility of expected inflation have declined significantly, especially since late-2000. This suggests that the BOM has earned credibility for its inflation targeting performance.

113. However, as measured by expectations, the implementation of inflation targeting has not been even. Inflationary expectations increased rapidly in mid-1998 (following a couple of years of relatively large foreign exchange interventions), before subsequent falling in 2000. The rapid decline could, in part, reflect the gradual reduction in foreign exchange interventions, but also follows a significant move by the BOM against inflationary pressures. ${ }^{38}$ It also coincides with the introduction of the Lombard facility, which the BOM

${ }^{38}$ In 1999, the BOM deliberately introduced a tight monetary policy to head off inflationary pressures during the recovery in 1998/99. Despite slow growth in 1999/00, the Lombard rate was raised to 12.0 percent, and to 12.5 percent in late-September and November 2000, respectively. The tighter stance was kept in place until May 2001, when the BOM began a series of easings, lowering the Lombard rate from 12.5 percent to 9.5 percent as of January 2004. 
introduced to improve transparency and its ability to signal the stance of monetary policy. The behavior of the slope suggests that aside from one (or, possibly, two) episodes, the spread between short- and long-term securities has remained relatively flat. Its sudden decline during 2000 may reflect lower (real) returns available in more advanced economies, and, possibly, a revision of growth prospects, given uncertainty about the future of trade preferences.

\section{F. Conclusion}

114. Mauritius's informal inflation targeting regime has been associated with a fall in inflation, and - as seen in Figure IV.3 - an impressive fall in inflationary expectations. That is, inflation targeting appears to have been able to provide a strong nominal anchor that has moderated inflationary expectations, and resulted in a steady reduction in actual inflation. These expectations are particularly important in the case of Mauritius, since they can provide a focal point during the centralized wage bargain process, thereby affecting inflation far into the future.

Figure IV.3. The Level and Slope of the Yield Curve

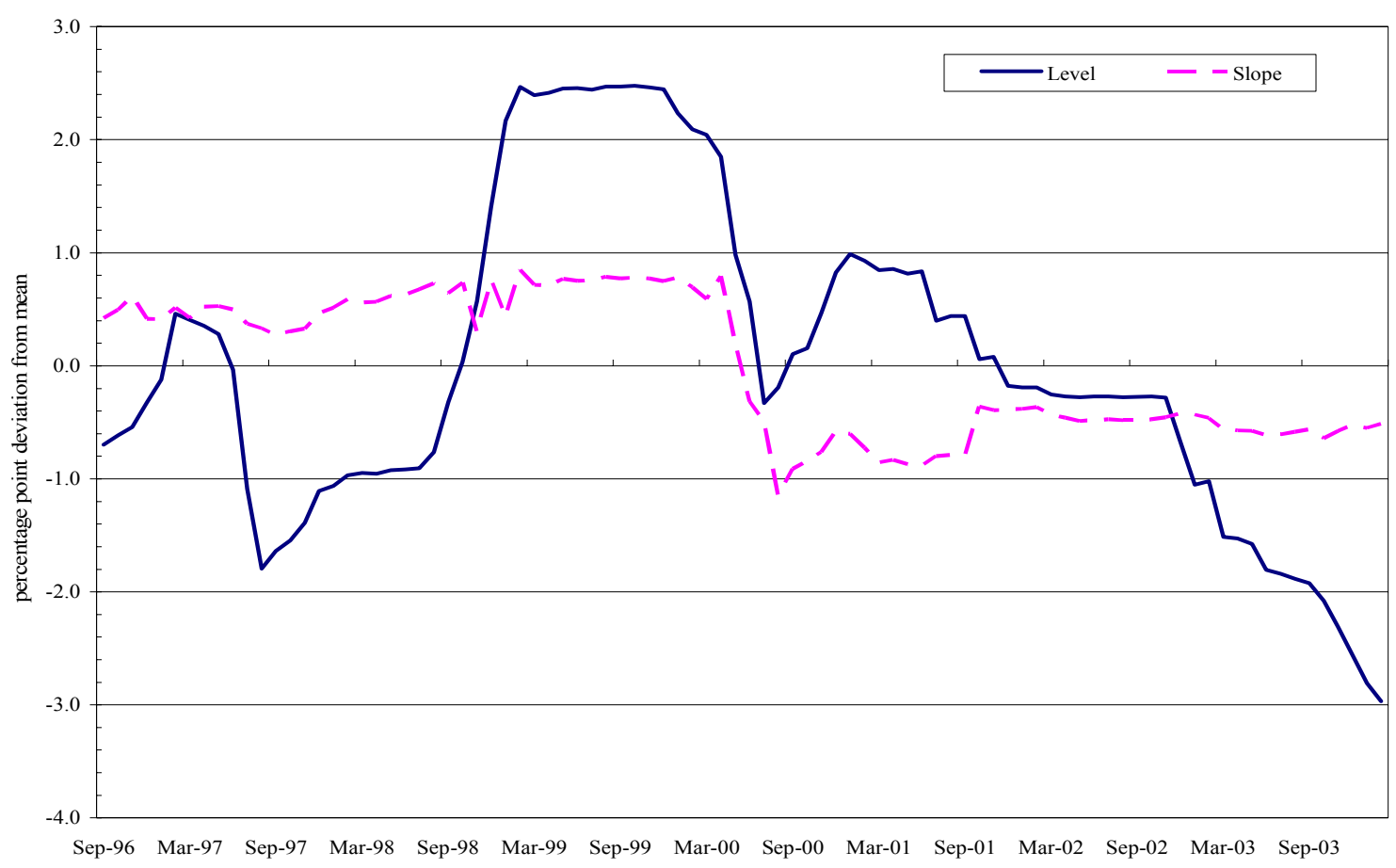

115. Although Mauritius does not yet have a fully fledged inflation targeting regime, its experience to date suggests the potential value of informal inflation targeting. Moreover, Mauritius has been able to anchor these expectations even while maintaining a managed exchange rate. By focusing on the aggregate CPI inflation expectation, the BOM has also anchored actual inflation, without generating excessive output volatility. Mauritius's 
experience suggests that, if carefully applied, inflation targeting jointly with a managed exchange rate can be a feasible policy alternative to a hard peg for small island economies. ${ }^{39}$

116. However, Mauritius's experience can be taken only so far. First, its experience comes against that backdrop of relatively subdued inflation worldwide. It remains to be seen how Mauritius's inflation targeting regime will fair if global inflation rises significantly. Second, it shows that even in a country with solid institutions, a lack of fiscal dominance, and low external debt, it can take a long time before the central bank has earned sufficient credibility to anchor expectations for low inflation.

\section{Appendix I}

\section{State space representation}

The dynamic system, (1'), (2), (3), (5'), (7), (8) and (9), can then be given the following state space representation $\Gamma_{0} Y_{t}=\Gamma_{1} Y_{t-1}+\Psi \varepsilon_{t}+\Pi \eta_{t}$, where the $x^{\text {th }}$ of $\eta_{t}$ is $\eta_{x t}=x_{t}-E_{t-1} x_{t}$, or the expectational forecasting error, and where $Y_{t}=\left[\begin{array}{llllllllllll}\pi_{t} & \pi_{t-1} & q_{t} & q_{t-1} & y_{t} & y_{t-1} & L_{t} & S_{t} & u_{S t} & E_{t} y_{y+1} & E_{t} q_{y+1}\end{array}\right]^{\prime}, \varepsilon_{t}=\left[\begin{array}{lllll}\varepsilon_{\pi t} & \varepsilon_{q t} & \varepsilon_{y t} & \varepsilon_{L t} & \varepsilon_{S t}\end{array}\right]^{\prime}$ and $\Gamma_{0}=\left[\begin{array}{ccccccccccc}1 & 0 & 0 & 0 & 0 & 0 & -\mu_{\pi} & 0 & 0 & 0 & 0 \\ 0 & 1 & 0 & 0 & 0 & 0 & 0 & 0 & 0 & 0 & 0 \\ 0 & 0 & 1 & 0 & 0 & 0 & 0 & \beta_{q S} & 0 & 0 & -1 \\ 0 & 0 & 0 & 1 & 0 & 0 & 0 & 0 & 0 & 0 & 0 \\ 0 & 0 & 0 & 0 & 1 & 0 & 0 & 0 & 0 & -\mu_{y} & 0 \\ 0 & 0 & 0 & 0 & 0 & 1 & 0 & 0 & 0 & 0 & 0 \\ \rho_{L}-1 & 0 & 0 & 0 & 0 & 0 & 1 & 0 & 0 & 0 & 0 \\ \left(\rho_{S}-1\right) \gamma_{\pi} & 0 & \left(\rho_{S}-1\right) \gamma_{q} & 0 & \left(\rho_{S}-1\right) \gamma_{y} & 0 & \left(1-\rho_{S}\right) \gamma_{\pi} & 1 & -1 & 0 & 0 \\ 0 & 0 & 0 & 0 & 0 & 0 & 0 & 0 & 1 & 0 & 0 \\ 0 & 0 & 0 & 0 & 1 & 0 & 0 & 0 & 0 & 0 & 0 \\ 0 & 0 & 1 & 0 & 0 & 0 & 0 & 0 & 0 & 0 & 0\end{array}\right]$

\footnotetext{
${ }^{39}$ Indeed, Mishkin (2004, p. 25) concludes that in the context of inflation targeting "... there is a rational for central banks in emerging market countries to smooth exchange rates," provided they do not go too far.
} 
$\Gamma_{1}=\left[\begin{array}{ccccccccccc}\left(1-\mu_{\pi}\right) \alpha_{\pi 1} & \left(1-\mu_{\pi}\right) \alpha_{\pi 2} & \alpha_{q} & 0 & \alpha_{y} & 0 & 0 & 0 & 0 & 0 & 0 \\ 1 & 0 & 0 & 0 & 0 & 0 & 0 & 0 & 0 & 0 & 0 \\ 0 & 0 & \beta_{q 1} & \beta_{q 2} & 0 & 0 & 0 & 0 & 0 & 0 & 0 \\ 0 & 0 & 1 & 0 & 0 & 0 & 0 & 0 & 0 & 0 & 0 \\ 0 & 0 & \beta_{q y} & 0 & \left(1-\mu_{y}\right) \beta_{y 1} & \left(1-\mu_{y}\right) \beta_{y 2} & 0 & -\beta_{r} & 0 & 0 & 0 \\ 0 & 0 & 0 & 0 & 1 & 0 & 0 & 0 & 0 & 0 & 0 \\ 0 & 0 & 0 & 0 & 0 & 0 & \rho_{L} & 0 & 0 & 0 & 0 \\ 0 & 0 & 0 & 0 & 0 & 0 & 0 & \rho_{S} & 0 & 0 & 0 \\ 0 & 0 & 0 & 0 & 0 & 0 & 0 & 0 & \rho_{u} & 0 & 0 \\ 0 & 0 & 0 & 0 & 0 & 0 & 0 & 0 & 0 & 1 & 0 \\ 0 & 0 & 0 & 0 & 0 & 0 & 0 & 0 & 0 & 0 & 1\end{array}\right]$

$\Psi=\left[\begin{array}{lllll}1 & 0 & 0 & 0 & 0 \\ 0 & 0 & 0 & 0 & 0 \\ 0 & 1 & 0 & 0 & 0 \\ 0 & 0 & 0 & 0 & 0 \\ 0 & 0 & 1 & 0 & 0 \\ 0 & 0 & 0 & 0 & 0 \\ 0 & 0 & 0 & 1 & 0 \\ 0 & 0 & 0 & 0 & 0 \\ 0 & 0 & 0 & 0 & 1 \\ 0 & 0 & 0 & 0 & 0 \\ 0 & 0 & 0 & 0 & 0\end{array}\right]$, and $\Pi=\left[\begin{array}{l}0 \\ 0 \\ 0 \\ 0 \\ 0 \\ 0 \\ 0 \\ 0 \\ 0 \\ 1 \\ 1\end{array}\right]$.

Using the Sims (2001) algorithm for linear rational expectations models, the system can be transformed into the form $Y_{t}=\Gamma Y_{t-1}+\Omega \varepsilon_{t}$, with the state vector of the system following the law of motion $F_{t}=\rho F_{t-1}+\Sigma \varepsilon_{t}$, where the state is $F_{t}=\left[\begin{array}{llllllllll}\pi_{t} & \pi_{t-1} & q_{t} & q_{t-1} & y_{t} & y_{t-1} & L_{t} & S_{t} & u_{S t}\end{array}\right]^{\prime}$.

\section{No arbitrage conditions}

For an economy where the state evolves according to $F_{t}=\rho F_{t-1}+\sum \varepsilon_{t}$, and the price of the risk associated with the factors underlying the term structure is represented by $\hat{\Lambda}_{t}=\hat{\lambda}_{0}+\hat{\lambda}_{1} F_{t}$, Rudebusch and $\mathrm{Wu}$ (2003) derive a recursive structure for an affine noarbitrage bond-pricing model. With the very short-term interest rate, $i_{t}$, expressed as a linear function of the state of the economy, $i_{t}^{1}=-\bar{A}_{1}-\bar{B}_{1}^{\prime} F_{t}$, they show that the yield on other maturities $\left(i_{t}^{j}=-\bar{A}_{j}-\bar{B}_{j}^{\prime} F_{t}\right)$ must satisfy following recursive patterns for $j>1$ :

$$
\begin{aligned}
& \bar{A}_{j}=\bar{A}_{j-1}-\bar{B}_{j-1}^{\prime} \Sigma \hat{\lambda}_{0}+\frac{1}{2} \bar{B}_{j-1}^{\prime} \Sigma \Sigma^{\prime} \bar{B}_{j-1}+\bar{A}_{1}, \text { and } \\
& \bar{B}_{j}=\bar{B}_{j-1}^{\prime}\left(\rho-\Sigma \hat{\lambda}_{1}\right)+\bar{B}_{1}^{\prime} .
\end{aligned}
$$




\section{Likelihood function of the macro finance model}

As described in the paper, the authors use data on inflation, private sector credit, and the real exchange rate, as well as the yields on 3-, 6-, and 12- month treasury securities. We stack the observed values in a vector $z_{t}=\left[\begin{array}{llllll}\pi_{t} & q_{t} & y_{t} & i_{t}^{3} & i_{t}^{6} & i_{t}^{12}\end{array}\right]^{\prime}$. Since we are estimating two latent factors from three yields, we must assume that one yield is measured with error. Following common practice, we assume the yield associated with the middle maturity -6 months - is measured with error (and distributed $N\left(0, \sigma_{6}\right)$ ). Assuming that conditional on the first $t-1$ observations, the $t$ th observation is Gaussian, then $z_{t}=\Gamma^{z} F_{t-1}+\Omega^{z} \xi_{t}$, where $\Gamma^{z}=\left[\begin{array}{c}\rho_{1, .} \\ \rho_{3, .} \\ \rho_{5, .} \\ B \rho\end{array}\right], \Omega^{z}=\left[\begin{array}{cc}\Sigma_{1, .} & 0 \\ \Sigma_{3, .} & 0 \\ \Sigma_{5, .} & 0 \\ B \Sigma & B^{m}\end{array}\right], B^{m}=\left[\begin{array}{c}0 \\ \sigma_{6} \\ 0\end{array}\right]$, and $\xi_{t}=\left[\begin{array}{c}\varepsilon_{t} \\ \varepsilon_{t}^{m}\end{array}\right]$, where $\varepsilon_{t}^{m}$ is the measurement error and where $B=\left[\begin{array}{lll}B_{3} & B_{6} & B_{12}\end{array}\right]^{\prime}, A_{j}=-\bar{A}_{j} / j$, and $B_{j}=-\bar{B}_{j} / j$. The log of the conditional density of the $t$ th observation is

$l l h_{t}=-\frac{1}{2}\left[\ln (2 \pi)+\ln \left(\operatorname{det}\left(\Omega^{z} \Omega^{z^{\prime}}\right)\right)+\left(z_{t}-\Gamma^{z} F_{t-1}\right)^{\prime}\left(\Omega^{z} \Omega^{z^{\prime}}\right)^{-1}\left(z_{t}-\Gamma^{z} F_{t-1}\right)\right]$,

with the conditional $\log$ likelihood being $L_{z_{T}, \ldots, z_{2} \mid z_{1}}\left(z_{T}, \ldots, z_{2} \mid z_{1} ; \theta\right)=\sum_{2}^{T} l l h_{t}$. Standard errors are computed using the outer product of gradients estimator.

\section{Appendix II}

\section{Mauritius: Parameter Estimates of the Macrofinance Open Economy Model ${ }^{40}$}

\section{Aggregate demand curve}

$$
\begin{array}{ll}
\mu_{y}=0.0223[0.4999] & \beta_{y_{1}}=0.0171[0.4996] \\
\beta_{q y}=0.0004[0.4997] & \beta_{r}=0.0064[0.4971]
\end{array}
$$

\section{Aggregate supply curve}

$$
\begin{array}{ll}
\mu_{\pi}=0.9110[0.1712] & \alpha_{\pi 1}=0.0216[0.4958] \\
\alpha_{q}=-0.1914[0.4987] & \alpha_{y}=-0.0135[0.49982]
\end{array}
$$

${ }^{40} \mathrm{P}$-values are in square brackets. 


\section{Inflation dynamics}

$\rho_{L}=0.9921[1.4 \exp (-64)]$

Real exchange rate dynamics

$\beta_{q 1}=0.996[0.3860] \quad \beta_{q 2}=0.999[0.0017]$

$\beta_{q S}=-0.0175[0.3229]$

Monetary policy reaction function

$$
\begin{array}{lll}
\rho_{S}=0.9958[2.7 \exp (-13)] & \gamma_{q}=0.8172[0.4998] & \gamma_{\pi}=0.3621[0.4857] \\
\gamma_{y}=0.0084[0.4999] & \rho_{u}=1 \exp (-5)[0.4999] &
\end{array}
$$

\section{Risk pricing matrix}

$$
\begin{array}{ll}
\lambda_{1}^{L L}=-0.1169[0.3809] & \lambda_{1}^{L S}=0.9903[0.2398] \\
\lambda_{1}^{S L}=-0.0151[0.4674] & \lambda_{1}^{S S}=-0.0259[0.4870]
\end{array}
$$

\section{Standard deviations}

$$
\begin{array}{lll}
\sigma_{L}=0.2802[0.0050] & \sigma_{S}=0.1545[0.2195] \\
\sigma_{\pi}=4.9877[9 \exp (-22)] & \sigma_{q}=0.0563[0.2163] & \sigma_{y}=.0400[0.1200]
\end{array}
$$

\section{Standard deviation of measurement error for the 6-month bond yield}

$$
\sigma_{6}=0.1690[5.7 \exp (-27)]
$$

\section{References}

Ball, Laurence, 1998, “Policy Rules for Open Economies," Research Discussion Paper 9806 (Sydney: Reserve Bank of Australia).

Dennis, Richard, 2001, "Monetary Policy and Exchange Rates in Small Open Economies," Federal Reserve Bank of San Francisco Economic Letter 2003-16 (May), (San Francisco: Federal Reserve Bank of San Francisco). 
Galí, Jordi, and Tommaso Monachelli, 2004, "Monetary Policy and Exchange Rate Volatility in a Small Open Economy," mimeo, Universitat Pompeu Fabra.

Hördahl, Peter, Oreste Tristani, and David Vestin, 2003, "A Joint Econometric Model of Macroeconomic and Term Structure Dynamics," mimeo, European Central Bank.

Mishkin, Frederic S., 2004, "Can Inflation Targeting Work in Emerging Market Countries?," paper presented at an IMF conference in honor of Guillermo A. Calvo, Washington, D.C., April.

Parrado, Eric, 2004, "Inflation Targeting and Exchange Rate Rules in an Open Economy," IMF Working Paper 04/21 (Washington: International Monetary Fund).

Rudebusch, Glenn, and Tao Wu, 2003, “A Macro-Finance Model of the Term Structure, Monetary Policy, and the Economy," Federal Reserve Bank of San Francisco Working Paper 2003-17 (September), (San Francisco: Federal Reserve Bank of San Francisco).

Sims, Christopher A., 2001, "Solving Linear Rational Expectations Models," Computational Economics, Vol. 20, pp. 1-20.

Svensson, Lars E. O., 2000, “Open Economy Inflation Targeting,” Journal of International Economics, Vol. 50, pp. 155-183. 


\section{Developing a Corporate Bond MARKet in MAuritius: Some Lessons from EMERGing MARKET COUNTRIES ${ }^{41}$}

\section{A. Introduction}

117. Mauritius has an efficient and a relatively large financial system. Its banking system is profitable and generally sound. It also has a well-developed insurance and pension sector, a number of nonbank financial institutions, and a stock market with capitalization of about 34 percent of GDP in 2003. The basic financial sector infrastructure, such as payment, securities trading and settlement systems, is modern and efficient. However, like many emerging market countries, the financial sector is dominated by banks (see Table V.1). The still growing offshore financial sector does not actively participate in local financial activities, and has yet to be fully integrated with the economy.

\section{The development of a corporate bond market could significantly enhance} Mauritius's financial stability. Credit to the private sector is highly concentrated in the onshore banking sector. The onshore banks' asset quality has presently come under pressure due to the economic difficulties facing the sugar and export processing zone (EPZ) sectors. Meanwhile, the pension and insurance companies are seeking longer-term assets that match the maturity structure of their liability portfolio. A well-functioning corporate bond market could improve the efficiency of the financial system by diversifying credit risk concentrated in the onshore banks, and can also provide a cheaper alternative to financing than bank loans for the corporate sector, which would ultimately facilitate growth in private investment.

\section{The purpose of this paper is to draw on lessons from other emerging countries'} experience in developing a corporate bond market and highlight some important requirements for developing such a market in Mauritius. Emerging market experiences indicate that developing a well-functioning corporate bond market is a complex and longterm task. It requires a series of well-designed reforms and assistance from the government in order to create the appropriate market environment to encourage the supply of corporate bonds, to build investor base, and to ensure a liquid market. High savings, investment-grade sovereign rating, strong institutions, and its position as an established off-shore financial center make Mauritius a good candidate for the development of a corporate bond market.

120. This paper is organized as follows. The next section reviews the financial system in Mauritius and identifies its main systemic risks. Section $C$ discusses the benefits of developing an efficient corporate bond market. Section D identifies factors that contribute to the development of an efficient corporate bond market in emerging market countries. In light of the emerging market experience, this section also discusses key issues that would need to be addressed for the development of a corporate bond market in Mauritius. Section E concludes.

${ }^{41}$ Prepared by Jung Yeon Kim and James Y. Yao. 


\section{B. The Financial System in Mauritius}

\section{Banking system}

121. The credit risk of the corporate sector is largely concentrated in the banking system, and the sectoral credit risk exposure is high. Within the onshore financial sector, banks account for about two-thirds of total assets. Their share of credit to the private sector in total assets is about 50 percent (see Table V.2). The Mauritius Commercial Bank (MCB) and State Bank of Mauritius (SBM), the two largest domestically owned banks, hold 70 percent of total assets and 77 percent of total loans in the domestic banking system, respectively. ${ }^{42}$ The sugar, tourism, and textiles industries account for some 40 percent of bank credit, and the sectoral distribution of credit is relatively skewed (see Figure V.1). Among the large sectors, manufacturing, including the EPZ, account for the second largest share of nonperforming loans (see FigureV.2).

122. The stress tests conducted by the Financial Sector Assessment Program (FSAP) in 2003 indicate that credit difficulty is the main risk facing the Mauritian banking system, although the high levels of capital and profits of the system, and the practice of extensive collateralization, provide a comfortable buffer against high-probability shocks. The most important risk is that the onshore banking system is vulnerable to external economic shocks and a downturn in economic activity. To guard against deterioration in the quality of their portfolios, banks have been reducing their exposure to sectors where the risk is considered the highest (see Table V. 3). For example, growth of the credit to the EPZ declined by 15.6 percent in 2002/03.

123. The offshore banking sector has grown rapidly since the second half of 1997 , but it is weakly integrated with the domestic economy. ${ }^{43}$ The assets of the 14 "Category 2 banks" 44 amounted to 94 percent of GDP in 2002, marginally less than the assets of domestic banks (see Table V.4). Offshore banks are allowed to collect foreign-currency denominated deposits from residents and can lend in foreign currency to residents and domestic firms. However, they do not have significant retail activity in Mauritius and have limited their domestic operations mainly to public sector borrowers. The offshore banks provide a wide

${ }^{42}$ In addition, there are three local operations of large international banks (HSBC, Barclays Bank and Bank of Baroda) holding 20 percent, and 5 small banks that hold 10 percent of total assets.

43 The number of institutions doubled from 7 to 14 from 1997 to 2002, and assets rose from about US\$910 million to US\$4.14 billion during the same period The offshore financial sector has developed in Mauritius largely due to the low tax environment, modern businessfriendly legislation for global business, and policies favoring open trade, capital flows, and exchange convertibility.

${ }^{44}$ The Category 1 banks represent domestic banks and Category 2 banks represent the offshore banks in Mauritius. 
variety of foreign-currency denominated services, including deposit taking, lending, foreign exchange dealing, trust fund management, asset financing, and securities custodial services.

Table V.1. Financial System Structure

(At the end of June 2002)

\begin{tabular}{|c|c|c|c|c|}
\hline & \multicolumn{4}{|c|}{ Total Assets } \\
\hline & $\begin{array}{l}\text { Number of } \\
\text { institutions }\end{array}$ & $\begin{array}{l}\text { Assets } \\
\text { (MUR } \\
\text { millions) }\end{array}$ & $\begin{array}{l}\text { In percent } \\
\text { of total } \\
\text { assets }\end{array}$ & $\begin{array}{l}\text { In percent } \\
\text { of } 2002 \\
\text { GDP }\end{array}$ \\
\hline Onshore banks & 10 & 134,675 & 37.8 & 97.6 \\
\hline Domestic & 4 & 102,958 & 28.9 & 74.6 \\
\hline Foreign & 6 & 31,717 & 8.9 & 23.0 \\
\hline Offshore banks & 12 & 129,205 & 36.3 & 93.6 \\
\hline Insurance companies & 22 & 27,160 & 7.6 & 19.7 \\
\hline Pension funds & 1,095 & 42,978 & 12.1 & 31.1 \\
\hline $\begin{array}{l}\text { Mauritius Housing } \\
\text { Company }\end{array}$ & 1 & 6,292 & 1.8 & 4.6 \\
\hline $\begin{array}{l}\text { Development Bank of } \\
\text { Mauritius }\end{array}$ & 1 & 6,176 & 1.2 & 3.2 \\
\hline Post Office Savings Bank & 1 & 1,032 & 0.3 & 0.8 \\
\hline Leasing companies & 12 & 7,116 & 2 & 5.2 \\
\hline $\begin{array}{l}\text { Asset management } \\
\text { compaines }\end{array}$ & 12 & 861 & 0.2 & 0.6 \\
\hline Credit finance companies & 262 & 696 & 0.2 & 0.5 \\
\hline Stock brokers & 11 & 438 & 0.1 & 0.3 \\
\hline Insurance brokers & 8 & 210 & 0.1 & 0.2 \\
\hline Management companies & 38 & 977 & 0.3 & 0.7 \\
\hline Corporate trustees & 11 & 46 & 0.0 & 0.0 \\
\hline Captive managers & 4 & 8 & 0.0 & 0.0 \\
\hline Total & 1,500 & 359,870 & 100.0 & 258.0 \\
\hline
\end{tabular}

Sources: The Mauritian authorities; and staff estimates. 
Table V.2. Summarized Aggregate Balance Sheet of Category 1 Banks as of Februrary 29, 2004

(In thousands of Mauritian rupees, unless otherwise indicated) 1/

\begin{tabular}{|c|c|c|c|c|c|}
\hline & Assets & $\begin{array}{c}\text { In percent } \\
\text { of total } \\
\text { assets }\end{array}$ & & Liabilities & $\begin{array}{r}\text { In percent } \\
\text { of total } \\
\text { liabilities }\end{array}$ \\
\hline Cash in hand & $2,595,531$ & 1.6 & Capital & $5,236,433$ & 3.2 \\
\hline Balances with BOM & $5,479,063$ & 3.4 & Reserves and surplus & $10,416,499$ & 6.4 \\
\hline BOM bills & $6,489,434$ & 4.0 & Subordinated loans & 125,000 & 0.1 \\
\hline Government securities & $32,589,785$ & 20.0 & Shareholder loans & 10,356 & 0.0 \\
\hline T-bills & $30,228,164$ & 18.6 & Deposits & $125,084,267$ & 76.8 \\
\hline T-bonds & $2,361,397$ & 1.4 & Priviate sector & $119,723,405$ & 73.5 \\
\hline Foreign assets & $11,791,872$ & 7.2 & Government & 153,994 & 0.1 \\
\hline Claims on private sector & $87,166,613$ & 53.5 & $\begin{array}{l}\text { Statutory and } \\
\text { parastatals }\end{array}$ & $5,202,013$ & 3.2 \\
\hline Loans & $78,822,004$ & 48.4 & Category 2 banks & 4,856 & 0.0 \\
\hline Stocks & $2,979,288$ & 1.8 & Borrowings & $7,902,136$ & 4.9 \\
\hline Debentures & $5,365,320$ & 3.3 & Of which: BOM & $1,893,266$ & 1.2 \\
\hline Claims on parastatals & $1,629,702$ & 1.0 & Of which: interbank & & 0.0 \\
\hline Loans & $1,186,102$ & 0.7 & Bills payable & 185,039 & 0.1 \\
\hline Stocks & 300 & 0.0 & Other liabilities & $13,896,626$ & 8.5 \\
\hline Debentures & 443,300 & 0.3 & & & \\
\hline Claims on banks & $1,956,254$ & & & & \\
\hline Category 2 & & 1.2 & & & \\
\hline Fixed assets & $8,322,520$ & 5.1 & & & \\
\hline Other assets & $4,821,663$ & 3.0 & & & \\
\hline Total & $162,856,355$ & 100.0 & Total & $162,856,355$ & 100.0 \\
\hline
\end{tabular}

Sources: Bank of Mauritius; and staff calculations.

1/ The balance sheets have been adjusted from BOM data to show net loans rather than gross loans on the asset side. 
Figure V. 1. Mauritian Onshore Banks: Sectoral Credit Distribution (as of Feb. 2004)

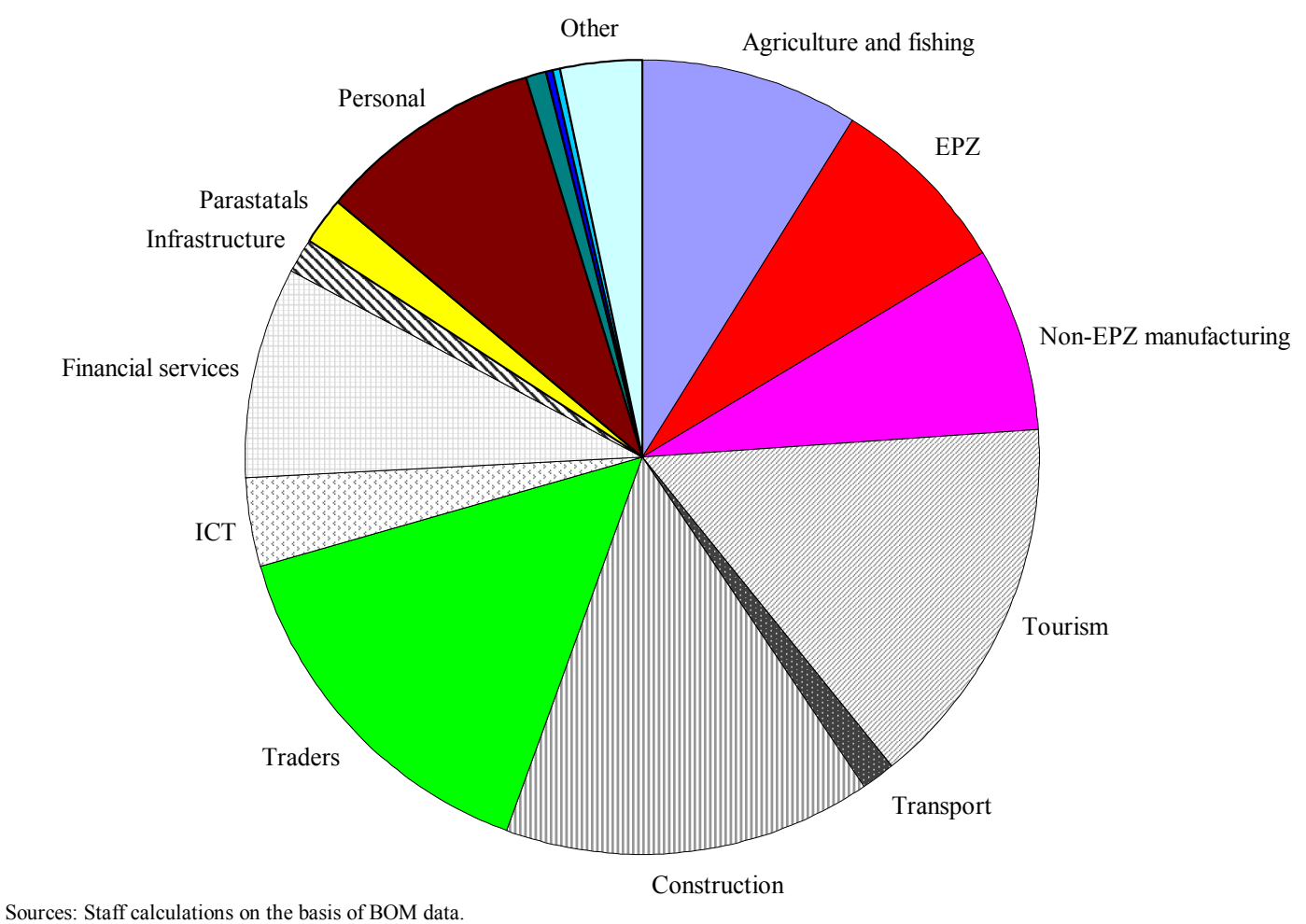

\section{Nonbanking financial institutions}

124. Nonbanking financial institutions (NBFIs) are well developed in Mauritius, but they face a maturity mismatch and reinvestment risks. Contractual savings, represented by the total assets of pension funds and insurance companies, are large and amounted to MUR 70 billion (50 percent of GDP) in 2002. The sector covers the National Pensions Fund (NPF), the National Savings Fund (NSF), 22 active insurance companies, and 1,095

occupational pension funds created by statutory bodies and private sector companies. Savings institutions have a strong demand for long-duration assets to match the maturity structure of their liabilities. In particular, life insurance companies face considerable reinvestment risk arising from a persistent fall in interest rates. 
Figure V.2. Nonperforming Loan Ratios Per Sector as of December 31,2003

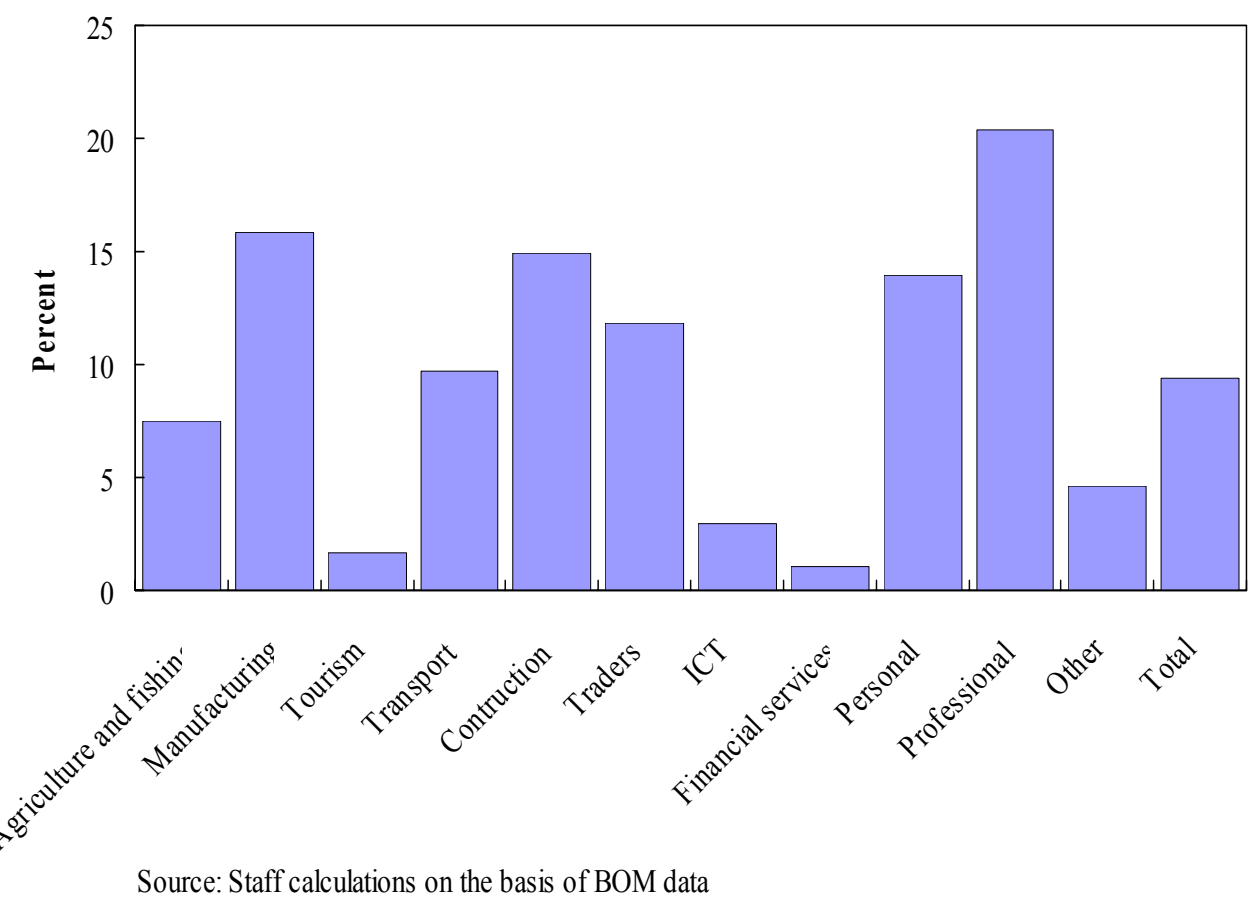


Table V.3. Sectoral Growth Rate of Credit to the Private Sector (In percent)

\begin{tabular}{|l|c|c|}
\hline $\begin{array}{l}\text { Sector of Mauritian } \\
\text { economy }\end{array}$ & June 2001-June 2002 & June 2002-June 2003 \\
\hline Agriculture and fishing & 19.9 & 10.2 \\
\hline EPZ & 1.5 & -15.6 \\
\hline Non-EPZ manufacturing & 11.8 & 11.8 \\
\hline Tourism & 16.4 & -3.6 \\
\hline Transport & 10.8 & 2.8 \\
\hline Construction & 4.8 & 8.4 \\
\hline Traders & 6.1 & 77.3 \\
\hline New economy (ICT) & 34.7 & -7.4 \\
\hline Financial services & 24.0 & 4.5 \\
\hline Infrastructure & -6.2 & 1.9 \\
\hline Other & -4.6 & \\
\hline Total & 8.1 & \\
\hline
\end{tabular}

Source: Bank of Mauritius and staff calculations. 
Table V.4. Summary Aggregate Balance Sheet of Category 2 Banks, as of February 29, 2004

(In thousands of U.S. dollars, unless otherwise indicated)

\begin{tabular}{|c|c|c|c|c|c|}
\hline & Assets & $\begin{array}{l}\text { In percent of } \\
\text { total assets }\end{array}$ & & Liabilities & $\begin{array}{c}\text { In percent of } \\
\text { total } \\
\text { liabilities }\end{array}$ \\
\hline Cash in hand (foreign notes) & 77 & 0.0 & Capital & 181,780 & 3.3 \\
\hline Amounts due from banks & $2,487,834$ & 44.7 & Reserves & 177,873 & 3.2 \\
\hline Investment & 251,017 & 4.5 & & & \\
\hline $\begin{array}{l}\text { T-bills of foreign } \\
\text { government }\end{array}$ & 0.0 & 0.0 & $\begin{array}{c}\text { Deposits of } \\
\text { nonbank } \\
\text { customers }\end{array}$ & $2,352,966$ & 42.3 \\
\hline Other foreign securities & 1,614 & 0.03 & & & \\
\hline $\begin{array}{l}\text { Other securities } \\
\text { in Mauritius }\end{array}$ & 1,046 & 0.02 & $\begin{array}{l}\text { Amounts due } \\
\text { to banks }\end{array}$ & $2,455,971$ & 44.1 \\
\hline Bonds & 0.0 & 0.0 & & & \\
\hline Notes & 48 & 0.0 & & & \\
\hline Equity & 0.0 & 0.0 & & & \\
\hline $\begin{array}{l}\text { Other securities } \\
\text { outside Mauritius }\end{array}$ & 248355 & 4.5 & $\begin{array}{l}\text { Bonds and } \\
\text { debentures } \\
\text { issued }\end{array}$ & 00 & 00 \\
\hline Bonds & 180,952 & 3.3 & & & \\
\hline Notes & 3,306 & 0.1 & & & \\
\hline Equity & 769 & 0.0 & & & \\
\hline Others & 63,328 & 1.1 & & & \\
\hline & & & Other & & \\
\hline Loans and advances & $2,668,613$ & 47.9 & liabilities & 397,857 & 7.1 \\
\hline Other assets & 158,905 & 2.8 & & & \\
\hline Total & $5,566,446$ & 100.0 & Total & $5,566,446$ & 100.0 \\
\hline
\end{tabular}

Source: Bank of Mauritius. 
Table V.5. Assets of Contractual Savings Institutions, 2001-02

(In millions of Maurtian rupees, unless otherwise indicated)

\begin{tabular}{lrr}
\hline & 2001 & 2002 \\
\hline Self-administered funds & 2,458 & 4,058 \\
Sugar Industry Pension Fund & 2,161 & 2,196 \\
Insured/administered funds & 8,904 & 10,922 \\
Occupational pension funds & 13,523 & 17,176 \\
NPF & 21,772 & 22,422 \\
NSF & 2,849 & 3,380 \\
Insurance companies & 23,972 & 27,160 \\
Total & 62,116 & 70,138 \\
Less double counting 1/ & 8,904 & 10,922 \\
Total contractual savings & & \\
Assets & 53,212 & 59,216 \\
Total assets/GDP ratio & 42.5 & 40.0 \\
\hline Source: FSC. & \multicolumn{2}{c}{ 1/ Insured and administered pension funds. }
\end{tabular}

Table V.6. Asset Allocation of Contractual Savings, 2000-02

\begin{tabular}{lccc}
\hline & \multicolumn{3}{c}{ Percent of Total Assets } \\
& 2000 & 2001 & 2002 \\
\hline & & & \\
Shares and debentures & 35 & 35 & 38 \\
Mortgage loans & 25 & 23 & 21 \\
Government securities & 7 & 9 & 13 \\
Deposits and securities & 13 & 14 & 9 \\
Land and property & 5 & 5 & 4 \\
Other loans & 5 & 4 & 4 \\
Other assets & 10 & 10 & 11 \\
Total & & & \\
\hline
\end{tabular}

Source: FSC.

\section{Domestic capital market}

125. The development of the capital market has lagged behind that of the banking sector. The short-term money market has been inactive, and there is some market 
segmentation, with the major foreign banks not offering interbank credit to smaller local banks. The primary government bond market is functioning well. ${ }^{45}$ Treasury bills at 3-, 6-, 12- and 24-month maturities are all sold at weekly auctions. ${ }^{46}$ The yield curve is generally reliable. However, the secondary bond market is at early stages of development.

126. The institutional, legal, and technical infrastructure of the Stock Exchange of Mauritius (SEM) is well developed, but the market is characterized by low volume, poor liquidity, and lack of depth. The SEM, incorporated in Mauritius on March 30, 1989, as a private limited company, operates two markets: the Official Market, on which securities of listed companies are traded, and the Over-The-Counter (OTC) Market. Currently, there are 40 companies listed on the Official Market representing a market capitalization of nearly US\$2.1 billion as at March 31, 2004. However, since the late 1990s, activities in the SEM have slowed. From 1999 to 2003, market capitalization declined from 37 percent to 34 percent of GDP, and the average turnover hovered around 6 percent, indicating that the market is small.

127. The corporate bond market has been functioning on the SEM for several years. Corporate debentures are traded by both the SEM as well as an OTC board in Mauritius. However, there has been no new issuances and trading activities are very low, partly because the government reversed its tax policy on interest payments a few years ago. The number of corporate debentures was 18 and 11 in December 2001 and December 2002, respectively. Total turnover value was MUS 1.81 million and 0.4 million, for December 2001 and December 2002, respectively, which only accounts for one hundred times the turnover value of equities during the same period.

\section{Corporate sector}

128. Surprisingly, in this small island economy, the corporate sector has a relatively large number of firms and a significant number of large firms. Summary statistics of the Registrar of Companies Financial, Incorporation, and Object databases show that the total number of corporations is about 10,000 in 2004. The number of large firms is about 450 and the number of medium firms is about $1,380 .{ }^{47}$ Although the main corporate source of financing is banking loans, the large firms may have an incentive to issue corporate bonds as an alternative corporate financing.

${ }^{45}$ A system of primary dealers (PD) was introduced in 2002. Four banks-SBM, MCB, HSBC, and Barclays - are the primary dealers.

46 The Development Loan Stock with maturities up to 15 years is issued annually, while the five-year bond is issued quarterly.

${ }^{47}$ Firm size is defined as follows: Small firms as less than MUR 10 million turnover; Medium firms as greater than MUR 10 million and less than MUR 80 million turnover; and Large firms as greater than MUR 80 million turnover. 
129. Banks and financial institutions enjoy strong and enforceable creditor rights, but the legal framework governing corporate insolvency ${ }^{48}$ needs to be updated. Nearly all corporate lending in Mauritius is done on a secured basis. Banks and financial institutions benefit from strong, preferential rights with respect to security and fixed and floating charges, but enforcement procedures are often slow and inefficient.

130. There is a need to improve creditor protection and increase the recovery rate of loans. A recent assessment by the World Bank (2004) concludes that, while the systems for creditor protection and credit recovery in Mauritius offer modern protection, court proceedings do not respond to the needs of a dynamic industry. Constraints in the systems and illiquid markets typically result in low recoveries, even for secured creditors.

131. The authorities have taken a number of measures to strengthen the governance of commercial entities. The Companies Act 2001, the new Listing, Rules, and the consolidation of financial regulation within the Financial Services Commission (FSC) have enhanced shareholder protections and contributed significantly to corporate governance improvements. In several areas, however, further reforms are necessary to enable shareholders to exercise better control over management and help protect against abuse, particularly in those cases where there is one dominant family or group that owns a controlling interest in the company's stock.

\section{Benefits of an Efficient Corporate Bond Market}

132. Advantages of a well functioning corporate bond market have been reviewed extensively in the literature. Boot and Thakor (1997) show that a financial system in its infancy will be bank dominated, and that bank lending declines as the financial market becomes more sophisticated. Hakansson (1999) compares the development of the economic structure between an economy with a well-developed corporate bond market and an economy in which bank financing plays a central role, suggesting a corporate bond market as a better way to control financial risks. Noel, Rebello, and Wang (2003) suggest that bond financing is a highly desirable choice for an economy in the long run because agents learn about the structure of security returns through trading experiences, and gravitate toward strategies that generate the highest payoffs. This results in the emergence of a financing hierarchy in which securitized debt dominates bank loans and other financing choices. Herring and Chatusripitak (2000) also conclude that the absence of a bond market may render an economy less efficient and significantly more vulnerable to financial crisis.

133. A corporate bond market can reduce the credit risk concentration in banks. In the absence of a corporate bond market, a major proportion of debt funding for corporations has to come from the banking sector. With a corporate bond market, however, the credit risk

${ }^{48}$ The basic law governing business activity in Mauritius is the Companies Act of 2001. This is heavily based on the New Zealand Companies Act of 1993, but tailored to suit the legal and commercial context of Mauritius. 
of the corporate sector could be born by a large number of market participants, including households, NBFIs, and foreign investment firms. A much cited quote by Alan Greenspan (2000) is that bond markets can act like a "spare tire," substituting for bank lending as a source of corporate funding at times when banks' balance sheets are weak and banks are rationing credit. ${ }^{49}$

134. In the case of Mauritius, bank credit to the private sector has continued to decline during the last several years, and there is excess liquidity in the banking system, partly because of the cautious attitude of banks toward credit risk. Medium-term growth is likely to slow to around 4 percent per annum, relative to the historical average growth rate of 5.5 percent. To sustain economic growth in the medium term, it is necessary for the economy to diversify the credit risk currently concentrated in the onshore banks' balance sheets.

135. For investors, an efficient corporate bond market provides long-term investment opportunities, and for the issuer, it lowers the cost of financing. The nonbank financial institutions, such as life insurance companies and pension funds, can reduce the maturity mismatch of assets and liabilities by investing in corporate bonds. For the issuer, by allowing firms to finance longer-term debts, corporate bonds enable the firms to invest in larger projects such as infrastructure and utilities, where substantial outlays may be required for some period of time before positive rates of return are realized. In addition, firms may reduce their financing costs by borrowing directly from investors, bypassing commercial banks. Also, while firms still go through underwriters, brokers and dealers to raise funds, the competition among these intermediaries is more intense compared to that of commercial banks, thus reducing intermediation costs.

136. The continued widening of interest rate differential between the average $\mathbf{T}$-bill yield and the average bank lending rate increases demands for cheaper corporate financing in Mauritius (see Figure V. 3). Given balance sheet concerns, onshore banks are reluctant to reduce their lending rates, despite the presence of excess liquidity. In addition, the corporate bond market could potentially position itself between the government bond yields and the bank lending rate.

${ }^{49}$ Although an empirical study by Jiang et al (2001) indicate that bond issuance and bank lending are usually positively correlated, in both OECD and emerging economies, this positive relationship may take place at the early stage of the corporate bond market development with heavy bank involvement. 
Figure V. 3. Differential between Average Bank Lending Rate and Average T-bill Rate

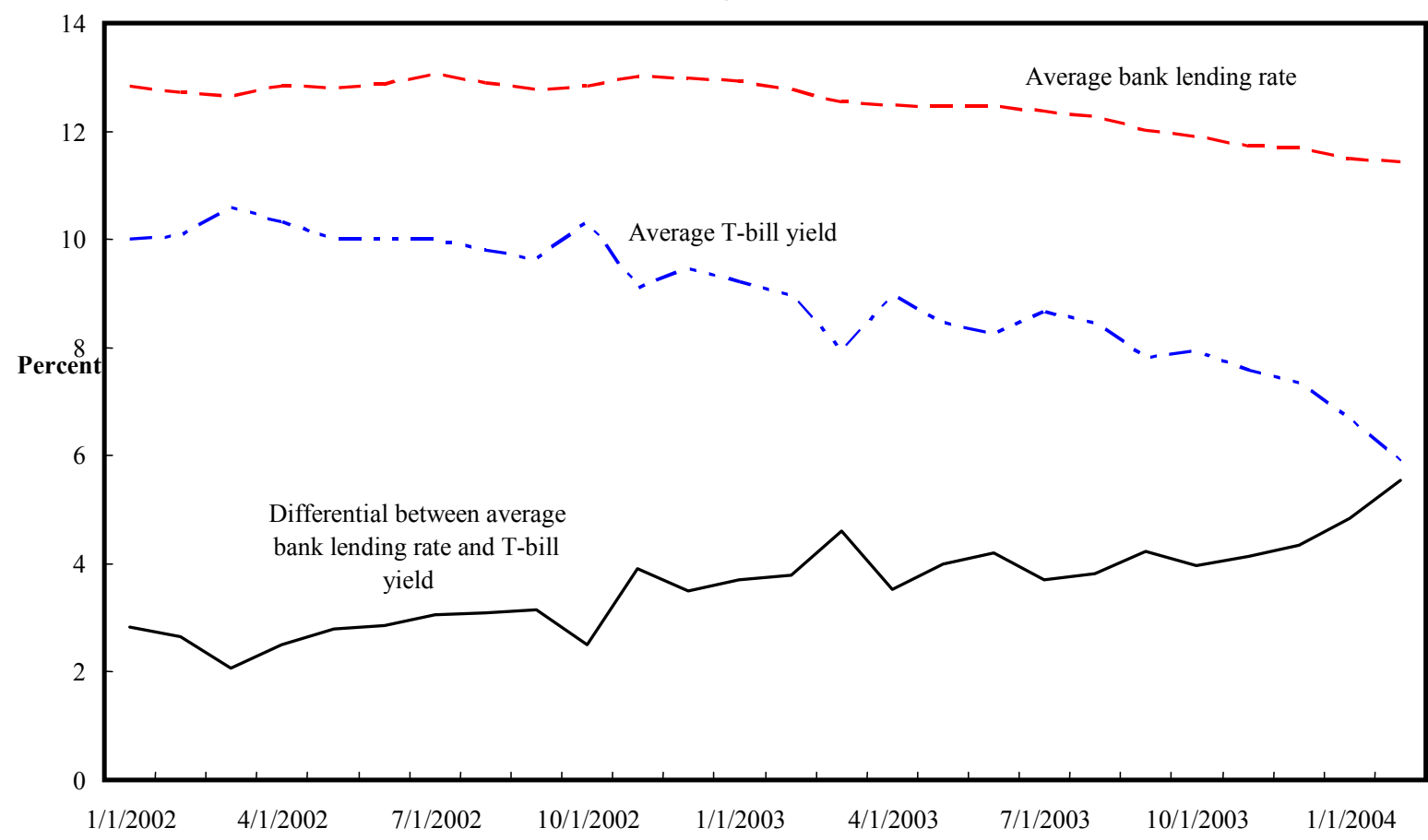

\section{Factors Contributing to the Successful Development of a Corporate Bond Market}

137. This section identifies a number of factors that appear to have been important in explaining the development (or lack of development) of corporate bond markets in emerging markets. The discussion is centered on six broad areas.

\section{Institutional and legal framework}

138. A crucial aspect of a well-functioning market is its legal framework and legal enforcement. Many successful countries, during their initial stage of development, adopted a legal system that incorporated an investor protection clause. Protection clauses define the limits of legal obligation for bankrupt issuers to repay their dues, and delineate procedures for enforcing them. Such a mechanism, similar to Chapter XI of the Bankruptcy Code in the U.S., gives companies protection from their creditors, while allowing investors to assess rationally the risks they face.

139. The legal framework should include information disclosure requirements on a regular basis. The authorities should ensure that corporate accounting standards are consistent with international practice, a lesson from the 1997 Asian crises. Even prior to the crises, these countries had operated large corporate bond markets. It was only revealed ex post that, due to the government's implicit guarantee to the corporate sector ("too big to 
fail'"), coupled with a poor credit rating mechanism, accounting standard, and reporting requirements, these bonds were mostly de facto bank loans.

140. Sound corporate governance is also critical for corporate bond market development. Better corporate governance can be implemented through several mechanisms, including improved laws, enhanced regulations and supervisions, and stronger enforcement of private contracts.

141. In Mauritius, creditor protection should be given the top priority based on the lessons from emerging market countries. The authorities need to improve the legal framework, which will address weaknesses mentioned in the 2004 ROSC assessment. In addition, sufficient creditor protection provisions and information disclosure requirements should be included in the current draft of the Security Act.

\section{Developing the benchmark}

142. An efficient government bond market increases the efficiency of pricing of corporate bonds. Market participants often use yields on certain "benchmark" issues to construct a term structure of risk-free returns, which are used in the pricing of a wider range of financial instruments, including and especially corporate bonds. Investors and issuers in such countries are more experienced with operations of securities markets, and are thus more likely to participate in the corporate bond market where a government bond market is active. The experiences of Asian countries indicate that the absence of an efficient government bond market could lead to a distorted corporate bond market development. In the case of Korea, the corporate bond market had been active prior to the crisis, despite a relatively underdeveloped government bond market. Without the benchmark yield curve provided by a large public debt market, especially in the shorter end of the curve, the pricing of corporate bonds was distorted, resulting in active trading of lower quality debts at high prices. This has been cited as one of the factors that triggered the financial crisis in 1997/98.

143. The operation of an efficient money market is also an important precondition for developing corporate bond markets. Schinasi and Smith (1998) argues that money markets provide an anchor to the short end of the yield curves and are critical for the pricing of bonds and bond derivatives.

144. In the case of Mauritius, the authorities should attempt to build a yield curve on the money market and establish a connection with the primary bond market. In doing so, the authorities should lengthen the maturities of current money market instruments from the existing one week to three months' maturities. Also, further efforts are needed to improve the liquidity of the secondary government bond market. Along with the recent stock exchange listings of government bonds, efforts should be geared toward increasing competition by allowing more dealers to enter this market. 


\section{Credit risk assessment}

145. The presence of reputable international credit rating agencies is recognized as an important factor for the success of a bond market. It contributes to eventual development of a well-functioning domestic credit rating system, which would increase the transparency of issuance and the transferability of corporate bonds, either in the primary or in the secondary market, and deepen the corporate bond market. Establishment and development of independent domestic credit agencies would provide sharper differentiation of credit risks within the domestic market.

146. The pricing mechanism of corporate bonds can improve through measures such as the standardization of bond contracts, stock exchange listings, rating requirements and proactive ratings by some institutional investors in the market. For example, since April 2000, the Thai authorities have required compulsory credit ratings for most corporate bonds to promote a credit culture and to discourage private placements from ending in the hands of unsophisticated retail investors. In the absence of credit rating agencies, as in the case of Chile, pension funds have played the role of rating agencies and have become the "price makers" in the market.

147. In the case of Mauritius, the establishment of a credit information bureau would improve loan qualities by allowing lenders to assess better the credit risk of firms. This should be followed by the eventual introduction of independent domestic credit rating agencies. Meanwhile, further efforts are needed to promote education and training on credit risk assessment. The presence of international rating agencies could contribute significantly during the early stages of developing credit risk assessment skills.

\section{Building the investor base}

148. One of the major obstacles in building an investor base is the crowding out effect of government bonds. In the case of Brazil, its debentures market faces major hurdles in becoming a reliable source of financing for the corporate sector because government securities are attractive to domestic investors (low credit risk, ample secondary market liquidity, high real yields, and in many cases, protection against exchange rate, inflation and interest rate risks through indexed bonds). Only local firms willing to pay rates in excess of 20 percent on three-year debentures are able to bid for domestic investors' funds.

149. Low and stable inflation, supported by credible monetary policy, is also important in building the investor base. When the government bond yields are sufficiently low under a stable, low inflation environment, the individual and institutional investors become motivated to invest in corporate bonds. However, if inflation is not stable, a reversal of the interest rate cycle might lead to excessive adjustments in bond prices, especially in the markets where hedging instruments are unavailable or highly illiquid.

150. Governments have often been involved in broadening the investor base during the initial stages of corporate bond market development. In the case of Korea, the government enacted the Securities Investment Trust Business Act, and presidential decrees 
and enforcement ordinances to introduce contractual-type investment trust companies (ITC) as a vehicle to mobilize domestic capital to build investor base. Commercial banks in Korea also introduced an investment vehicle, the bank trust accounts, and employed this new tool to enter the trust businesses. As a complementary measure to developing an investor base, the Korean government devised a safety net to encourage investor confidence by adopting a bond guarantee scheme during the early stage of development. In the case of Malaysia, which has also one of the largest corporate bond markets in emerging markets, the government established the Cagamas Berhad, the national mortgage corporation, in 1987, to develop a secondary mortgage market and at the same time promote the development of the corporate bond market.

151. Banks can contribute to increasing demand for corporate bonds. In some countries, banks are major holders of corporate bonds. For example, in Indonesia, banks hold the majority of corporate bonds, and this was the case in Argentina, Brazil, Chile, and Malaysia. Banks may hold a smaller portion over time as institutional investors develop. Banks typically hold a large share of short-term government debt to meet liquidity requirements and they dominate the short-end of the bond market.

152. NBFIs, such as pension funds and insurance companies, also play an important part in the development of a corporate bond market in the medium term. For example, the Chilean pension reform in the early 1980s had a significant positive effect on the development of the long-term corporate bond market. This was so because pension funds (and also insurance companies) were in need of a larger asset base and longer term assets to reduce the mismatch of their asset/liability portfolio. The issuance of corporate bonds in Chile rose from less than US\$100 million in 1995 to over US\$10 billion in 2003.

153. It is also important to develop the retail investor base in the long run. In order to widen the retail investor base, both Hong Kong SAR and Singapore have initiated programs designed to place a portion of the assets of the mandatory provident funds in the hands of private fund managers. Hong Kong SAR's Mandatory Provident Fund trustees have received more inflows than expected when the system started in December 2000; one-third of the funds is invested in the bond market. In Singapore, demand for bonds has also been generated by farming out part of the assets of the Central Provident Fund to private asset managers, and by the placement of investment mandates of the government and other government-linked entities with private sector fund managers. Issuing bonds in smaller bills would also extend investment opportunities to individuals and enlarge the investor base, especially in Mauritius where the household saving rate is very high.

\section{Measures such as favorable tax treatment for investors, and issuance of} securitized bonds, are also effective in attracting investors. Singapore has implemented various kinds of tax incentives to participate in the debt market, that benefit both residents and nonresidents. In particular, foreigners have been allowed to borrow from domestic banks in order to invest in the domestic corporate bond market, and have been granted tax exemptions on interest income earned. With regard to securitized bonds, Chile has experienced a strong increase in these bonds, rising from an issuance of below US\$50 
million in 1999 to over US\$1.4 billion in 2003, by starting with mortgage loans and expanding it to car loans, credit card, and university credit.

155. In the case of Mauritius, the government should harmonize the tax treatment of interest income on all financial instruments, and aim to remove tax and other barriers that discourage the issuance of corporate bonds and the active presence of institutional investors in corporate bond markets. Mauritius should also take advantage of its foreign clientele network from the OFCs, both as the issuer (as in the case of Switzerland) and as the investor to boost corporate bond market activities. Stock listings of corporate bonds can also be explored as a venue to expand the retail investor base.

\section{Building the issuer base}

156. Various government strategies have been introduced to boost the supply of corporate bonds. Attracting more issuers can be difficult for a small economy. It becomes even more difficult if the economic outlook is bleak, because firms are not willing to increase investments. Some countries facing similar limitations began by encouraging statutory boards and government-linked corporations to tap the bond markets rather than opt for direct bank lending. The financial centers of Hong Kong SAR and Singapore have encouraged statutory boards and government-linked corporations to issue local bonds to help develop the market.

157. The government can play a proactive role in attracting foreign issuers. In the case of Singapore, the government has been actively encouraging issues not only from Singapore but also from foreign issuers. After the development of the market infrastructure and the establishment of a benchmark yield curve, the Singapore authorities removed some of the remaining restrictions that prevented the internationalization of the Singapore dollar. The recent liberalization measures complement previous efforts to attract foreign asset managers and strengthen Singapore's position as the main Southeast Asian financial center. It has been emulating Switzerland, where foreign entities are active issuers of Swiss franc bonds. ${ }^{50}$

158. Banks can become a large issuer of bonds. In several countries, such as Brazil, China, Germany, India, and Indonesia, banks use bond markets to supplement deposits as a source of funds. Banks may also act as underwriters for corporate bond issues, promising to take up any shortfalls if corporate bonds cannot be sold at an agreed minimum price

\footnotetext{
${ }^{50}$ It should be noted that opening the market to foreigners may entail foreign exchange rate risk. In the case of Singapore, the government required foreign issuers to convert or swap their Singapore dollar proceeds into a foreign currency before remitting abroad in order to limit Singapore dollars held outside of the country and preventing the possibility of its currency being used to attack the exchange rate. To compensate investors, the Singaporean authorities have opened the door for currency swaps, resulting in a "synthetic" foreign currency loan for foreign issuers.
} 
(maximum yield). Banks then take on market risk rather than credit risk. Over 90 percent of bonds in Hong Kong are underwritten by banks.

159. Credit guarantees can help issuers with low credit ratings to issue higher-grade bonds to gain access to the market. Many countries have introduced bond guarantee schemes for credit enhancement purposes. In such cases, banks became the guarantors and earn fee income by guaranteeing full or partial repayment on corporate bonds.

160. Asset securitization may allow private entities to free up more capital and financial resources. In particular, the issuance of asset-backed securities (ABS), can prove useful to borrowers without a well-established track record to raise funds through the bond market, and which may be particularly relevant to young, second-tier companies new to the bond market and without a high credit profile. Many companies in Mauritius could fall under this category. The jurisdictions that have adopted a formal ABS issuance framework include South Africa and Singapore. Argentina has also seen strong growth in ABS issuance following introduction of securitization facilities, with ABS issues growing by six times over the period 1998-2000.

161. In the case of Mauritius, the onshore banks can become the initial issuers of corporate bonds to finance their assets. Consideration should be given to extend this privilege to the offshore banks. The development of asset-backed securities, including mortgage securitization, could provide liquidity to lenders. This would assist lenders in diversifying their credit risk and allow them to lend on a longer-term basis without maturity mismatches.

\section{A relatively large number of big firms in Mauritius's corporate sector can} potentially become the main issuer base for the corporate bonds in the long term. Credit enhancements, such as collateral and guarantees, could lower the costs of new issues and help firms access the corporate bond market. However, about 40 domestic firms listed in the SEM, which have already had some track records for assessing credit risk, could become the initial issuers of the corporate bond market.

\section{Developing efficient primary and liquid secondary markets}

163. A successful launch of a primary corporate bond market depends heavily on the cost of issuance of bonds. In Hong Kong SAR, for instance, the cost of public issuance is estimated to be four times that of the private placement, and this has been cited as one factor that constrains the development of corporate bond markets. In the case of India, the lengthy issuance procedure has contributed to the dominance of private placements.

164. Many countries continue to face relatively inactive secondary markets, even after successful launch of bond markets. Very often, the system lacks transparency in the market-making process, thus inducing institutional investors to hold securities to maturity. The secondary market is, thus, prone to experience low liquidity and market fragmentation, often together with information asymmetry, and the corporate bond market faces pricing anomalies. Regulatory restrictions that prevent banks from doing repurchase agreements with 
corporate bonds are also seen as an obstacle for the development of a liquid secondary market. Many countries are tackling the problem by first fostering government bond markets to establish a solid benchmark yield curve and to familiarize market participants with bond trading. Some emerging markets have introduced credit derivatives markets to foster active trading in the secondary market. In the case of Singapore, the authorities opened up the liquid swap market to offshore banks and securities dealers, and provided market players with a hedging mechanism by launching the three-month Singapore dollar interest rate futures contract and Singapore Government Securities bond futures contract. The country has also made the infrastructure more conducive to market development by encouraging the use of ebond technology and business.

165. To improve regulation of corporate bond markets, many jurisdictions are trying to encourage more organized, stock exchange-based trading of bonds, as it is viewed as being better regulated. A stock exchange listing can serve a useful function in secondary markets for bonds, even if most trading occurs on the OTC. Exchange listing provides an important safeguard for small investors, and therefore contributes positively to liquidity of the overall market. However, bond markets typically remain a wholesale market, and the OTC may play a more important role. In some countries, the authorities have taken steps to formalize OTC activities, with a view to achieving some benefits of exchange-based trading within an OTC setting.

166. In the case of Mauritius, issuance procedures for corporate bonds should be simplified and transparency strengthened in the current draft of the Security Act and other related laws. Although private placement has a low cost compared with public issuance, Mauritius should exercise caution on private placement, especially if it wants to develop a regional corporate bond market.

167. It is expected that Mauritius would have difficulties in increasing liquidity on the secondary corporate bond market. The standardization of the corporate bond contract is helpful for liquidity of the secondary market. In addition, developing a credit derivative market can contribute to increased liquidity.

\section{E. Conclusion}

168. Mauritius is both well placed and in need of developing a corporate bond market. The well-developed financial sector, the good legal system, sound corporate governance, a relatively large corporate sector, and strong public institutions serve as good foundations to develop such a market. In addition, institutional investors such as NBFIs are seeking long-term investment opportunities. Furthermore, Mauritius's corporate sector needs a lower-cost financing option than currently dominant bank loans. Also, the corporate bond market allows firms to issue longer-term debts for larger projects and other capital-intensive investments necessary for long-term growth. Finally, the development of a corporate bond market is also timely, given the current low interest rate environment and widening differential between average T-bill yield and average bank lending rate. 
169. However, developing an efficient corporate bond market in Mauritius requires a welldesigned strategy, long-term reform efforts, and an active government role. In light of the emerging market experiences discussed in the previous sections, the following factors are critical: (i) improving the legal framework; (ii) developing the benchmarks;(iii) improving credit risk assessment skills;(iv) enlarging the investor base; (v) building the issuer base; and (vi) developing efficient primary and secondary bond markets.

\section{References}

Bondt, G.J., de, "2000 Off-Balance-Sheet Activities in Europe: Empirical Evidence from Bank-Level Panel Data," in: Financial Structure and Monetary Transmission in Europe: A Cross-Country Study, Edward Elgar, Cheltenham, (UK/ Northampton, MA, USA), pp. 46-64.

Bondt, G. J., de and D. Marques, 2004 "The High Yield Segment of the Corporate Bond Market: a Diffusion Modeling Approach for the U.S., the U.K.and the Euro area," ECB Working Paper Series, No.313.

Boot, A. and A. Thakor, 1997 The Review of Financial Studies, 0893-9454, Vol. 10, No. 3, pp. 693-733.

Boswijk, H., and P. Franses, 2002“The Econometrics of the Bass Diffusion Model,” Erasmus Research Institute of Management, ERS-2002-66-MKT.

Davis, S., 1979 "Diffusion of Innovations", Cambridge University Press. Easingwood, C. J., V. Mahajan and E. Muller, 1983 "A Nonnuniform Influence Innovation Diffusion Model of New Product Acceptance”, Marketing Science, 2, 3, 273-295.

Griliches, Z., 1957 "Hybrid Corn: an Exploration in the Economics of Technical Change," Econometrica 25, pp. 501-522.

Gruber, H. and F. Verboven, "The Diffusion of Mobile Telecommunications Services in the European Union," European Economic Review, 45, 3, 577-588.

Hakansson, Nils H. 1999 "The Role of a Corporate Bond Market in an Economy - and in avoiding crises," draft, (University of California, Berkely).

Herring, Richard and N. Chatusripitak, 2000 "The Case of the Missing Bond Market and Why it Matters for Financial Development," ADB Institute Working Paper 11, 2000.

Jagtiani, J., A. Saunders and G.F. Udell, 1995 "The Effects of Bank Capital Requirements on Bank Off-Balance Sheet Financial Innovations," Journal of Banking and Finance, 19, pp. 647-658. 
Jeuland, A., 1981 "Parsimonious Models for Diffusion of Innovation: Derivation and Comparison", Working Paper, Marketing Department, Graduate School of Business (University of Chicago).

Jiang, 2001, “Cost-Benefit Analysis of Developing Debt Markets,” Hong Kong Monetary Authority Quarterly Bulletin, no.29.

La Porta, Lopez de Silanes, Schleifer and Vishny, 1998 "Law and Finance”, JPE 106.

Mahajan, V. and R.A. Peterson, 1978 "Innovation Diffusion in a Dynamic Potential Adopter Population," Management Science, 24, pp. 1589-1598.

Molyneus, P. and N. Shanroukh, 1996 "Diffusion of Financial Innovations: the Case of Junk Bonds and note issuance facilities", Journal of Money, Credit and Banking, 28, 3, pp. 502-522.

Schinasi, G. and T. Smith, "Fixed-Income Markets in the United States, Europe, and Japan: Some Lessons for Emerging Markets," IMF Working Paper, 98/173.

Thomas H. Noel, Michael J. Rebello, and Jun Wang, 2003 "Corporate Financing: An Artificial Agent-Based Analysis," The Journal of Finance, Volume 58, Issue 3, p. 943.

Yago, G. and S. Trimbath, 2003 "Beyond Junk Bonds: Expanding High Yield Markets", (Oxford University Press).

World Bank, 2004 "Report on Observance of Standard and Codes: Mauritius, Insolvency and Creditor Rights System". 
Table 1. Mauritius: GDP Real Growth Rates by Industrial Origin, 1999-2003

(Annual change in percent)

\begin{tabular}{|c|c|c|c|c|c|}
\hline & 1999 & 2000 & 2001 & $\begin{array}{c}2002 \\
\text { Rev. Est. }\end{array}$ & $\begin{array}{c}2003 \\
\text { Prov. }\end{array}$ \\
\hline \multicolumn{6}{|l|}{ Agriculture, forestry, hunting, } \\
\hline and fishing & -25.8 & 33.3 & 7.2 & -14.4 & 1.4 \\
\hline Sugarcane growing & -43.9 & 64.5 & 9.9 & -19.3 & 2.7 \\
\hline Other agriculture & 3.1 & 9.4 & 4.3 & -8.4 & 0.0 \\
\hline Mining and quarrying & 3.0 & 3.0 & 3.0 & -50.0 & 3.0 \\
\hline Manufacturing & 2.0 & 7.9 & 4.4 & -2.1 & 0.3 \\
\hline Sugar milling & -45.0 & 64.5 & 9.9 & -19.3 & 2.7 \\
\hline Export processing zone & 6.0 & 6.0 & 4.4 & -6.0 & -4.0 \\
\hline Other manufacturing & 5.1 & 7.0 & 4.1 & 4.2 & 4.4 \\
\hline Electricity, gas, and water & 8.6 & 23.2 & 11.2 & 2.3 & 5.4 \\
\hline Construction & 8.5 & 7.5 & 1.5 & 7.6 & 12.0 \\
\hline \multicolumn{6}{|l|}{ Wholesale and retail trade, repairs and } \\
\hline personal and household goods & 5.1 & 3.2 & 3.2 & 3.2 & 3.2 \\
\hline Wholesale and retail trade & 5.0 & 3.0 & 3.0 & 3.0 & 3.0 \\
\hline Other retail services & 7.7 & 8.0 & 8.0 & 8.0 & 8.0 \\
\hline Hotels and restaurants & 4.0 & 13.5 & 1.0 & 3.2 & 2.7 \\
\hline \multicolumn{6}{|l|}{ Transport, storage, } \\
\hline and communications & 7.4 & 11.4 & 8.9 & 6.7 & 6.4 \\
\hline Financial intermediation & 10.3 & 14.6 & 11.0 & 2.0 & 6.1 \\
\hline Insurance & 6.0 & 5.0 & 10.0 & 8.0 & 6.2 \\
\hline Banking and other (including offshore) & 12.2 & 18.5 & 11.4 & 0.0 & 6.1 \\
\hline Real estate, renting, and business activities & 6.2 & 6.4 & 7.2 & 6.5 & 6.6 \\
\hline Ownership of dwellings & 3.2 & 3.1 & 3.6 & 3.2 & 3.2 \\
\hline Other & 9.7 & 9.9 & 10.8 & 9.5 & 9.4 \\
\hline $\begin{array}{l}\text { Public administration, defense, } \\
\text { and social security }\end{array}$ & 3.6 & 4.5 & 3.9 & 6.3 & 4.8 \\
\hline Education & 6.4 & 8.8 & 4.7 & 5.0 & 6.2 \\
\hline Health and social work & 7.8 & 6.1 & 5.8 & 8.3 & 7.4 \\
\hline Other services & 7.0 & 5.3 & 6.9 & 6.0 & 7.6 \\
\hline Imputed bank service charges & 12.2 & 18.5 & 7.0 & 5.5 & 5.1 \\
\hline GDP at basic prices & 2.3 & 9.3 & 5.6 & 1.9 & 4.4 \\
\hline Taxes on products (net of subsidies) & 6.0 & 3.9 & 2.5 & 3.0 & 4.0 \\
\hline GDP at market prices & 2.8 & 8.6 & 5.2 & 2.0 & 4.4 \\
\hline
\end{tabular}

Source: Central Statistics Office, National Accounts of Mauritius. 
Table 2. Mauritius: GDP at Current Prices by Industrial Origin, 1999-2003

(In millions of Mauritian rupees)

\begin{tabular}{|c|c|c|c|c|c|}
\hline & 1999 & 2000 & 2001 & $\begin{array}{c}2002 \\
\text { Rev. Est. }\end{array}$ & $\begin{array}{r}2003 \\
\text { Prov }\end{array}$ \\
\hline Agriculture, forestry, hunting, & & & & & \\
\hline and fishing & 5,613 & 7,144 & 8,434 & 7,910 & 8,440 \\
\hline Sugarcane growing & 2,433 & 3,742 & 4,646 & 4,102 & 4,500 \\
\hline Other agriculture & 3,180 & 3,402 & 3,788 & 3,808 & 3,940 \\
\hline Mining and quarrying & 134 & 142 & 150 & 75 & 80 \\
\hline Manufacturing & 22,432 & 24,702 & 27,423 & 28,278 & 29,401 \\
\hline Sugar milling & 546 & 840 & 1,436 & 1,268 & 1,390 \\
\hline Export processing zone & 11,697 & 12,523 & 13,681 & 13,600 & 13,450 \\
\hline Other manufacturing & 10,189 & 11,339 & 12,306 & 13,409 & 14,560 \\
\hline Electricity, gas, and water & 1,412 & 1,820 & 2,634 & 2,971 & 3,365 \\
\hline Construction & 5,620 & 6,225 & 6,540 & 7,319 & 8,450 \\
\hline Wholesale and retail trade and other & & & & & \\
\hline retail services & 12,312 & 13,010 & 13,745 & 14,715 & 16,025 \\
\hline Wholesale and retail trade & 11,842 & 12,464 & 13,125 & 14,000 & 15,200 \\
\hline Other retail services & 470 & 545 & 620 & 715 & 825 \\
\hline Hotels and restaurants & 5,630 & 5,860 & 7,430 & 7,550 & 7,990 \\
\hline $\begin{array}{l}\text { Transport, storage, } \\
\text { and communications }\end{array}$ & 11,314 & 13,577 & 15,124 & 16,844 & 18,735 \\
\hline Financial intermediation & 7,607 & 9,555 & 11,472 & 11,901 & 13,485 \\
\hline Insurance & 2,220 & 2,400 & 2,851 & 3,251 & 3,700 \\
\hline Banking and other (including offshore) & 5,387 & 7,156 & 8,622 & 8,650 & 9,785 \\
\hline Real estate, renting, and business activities & 8,431 & 9,372 & 10,517 & 11,743 & 13,144 \\
\hline Ownership of dwellings & 4,358 & 4,672 & 5,034 & 5,406 & 5,805 \\
\hline Other & 4,073 & 4,700 & 5,483 & 6,337 & 7,340 \\
\hline $\begin{array}{l}\text { Public administration, defense, } \\
\text { and social security }\end{array}$ & 6,402 & 7,000 & 7,438 & 8,106 & 9,315 \\
\hline Education & 4,300 & 4,833 & 5,222 & 5,661 & 6,460 \\
\hline Health and social work & 2,754 & 3,032 & 3,311 & 3,722 & 4,340 \\
\hline Other services & 3,723 & 3,952 & 4,407 & 4,868 & 5,515 \\
\hline Imputed bank service charges & $-4,356$ & $-5,707$ & $-6,290$ & $-6,968$ & $-7,650$ \\
\hline GDP at factor cost & 93,328 & 104,517 & 117,558 & 124,696 & 137,094 \\
\hline Sugar & 2,979 & 4,582 & 6,083 & 5,370 & 5,890 \\
\hline Nonsugar & 90,349 & 99,935 & 111,475 & 119,326 & 131,204 \\
\hline Net indirect taxes & 14,116 & 14,977 & 14,498 & 16,951 & 19,700 \\
\hline GDP at market prices & 107,444 & 119,494 & 132,056 & 141,647 & 156,794 \\
\hline
\end{tabular}


Table 3. Mauritius: Real Growth Rates of Expenditure on GDP, 1999-2003

(Annual change in percent)

\begin{tabular}{|c|c|c|c|c|c|}
\hline & 1999 & 2000 & 2001 & $\begin{array}{c}2002 \\
\text { Rev. Est. }\end{array}$ & $\begin{array}{l}2003 \\
\text { Prov. }\end{array}$ \\
\hline Consumption & 4.2 & 4.0 & 3.2 & 3.3 & 3.7 \\
\hline Private & 3.9 & 3.5 & 2.8 & 2.8 & 3.6 \\
\hline Government & 5.6 & 6.5 & 5.3 & 5.6 & 4.6 \\
\hline Gross fixed capital formation & 22.1 & -8.2 & 2.7 & 1.9 & 11.2 \\
\hline Private & 10.6 & 0.8 & -2.7 & 2.0 & -5.5 \\
\hline Public 1/ & 53.1 & -25.6 & 16.8 & 1.3 & 48.2 \\
\hline Exports & 1.4 & 4.0 & 17.4 & -7.0 & -3.0 \\
\hline Goods excluding Freeport activities, f.o.b. & -3.7 & 0.1 & 11.7 & -5.4 & -4.7 \\
\hline Freeport activities, f.o.b. & -18.0 & 35.5 & 46.2 & -13.1 & -1.4 \\
\hline Nonfactor services & 13.9 & 6.3 & 20.6 & -8.0 & -1.0 \\
\hline Imports & 4.7 & 2.2 & 4.6 & -4.3 & -1.3 \\
\hline Goods excluding Freeport activities, f.o.b. & 9.3 & 7.5 & -0.6 & -2.5 & -1.3 \\
\hline Freeport activities, f.o.b. & -21.4 & 35.7 & 44.0 & -23.1 & -10.8 \\
\hline Nonfactor services & -3.1 & 8.8 & 11.1 & -4.2 & 0.5 \\
\hline GDP at market prices & 2.8 & 8.6 & 5.2 & 2.0 & 4.4 \\
\hline
\end{tabular}

Source: Central Statistics Office, National Accounts of Mauritius.

1/ Includes purchases of ships and/or aircraft. 
Table 4. Mauritius: Expenditure on GDP at Current Prices, 1999-2003

(In millions of Mauritian rupees)

\begin{tabular}{|c|c|c|c|c|c|}
\hline & 1999 & 2000 & 2001 & $\begin{array}{r}2002 \\
\text { Rev. Est. }\end{array}$ & $\begin{array}{l}2003 \\
\text { Prov. }\end{array}$ \\
\hline Consumption & 82,903 & 89,521 & 96,864 & 106,240 & 117,050 \\
\hline Private & 68,710 & 73,939 & 80,112 & 88,038 & 96,350 \\
\hline Government & 14,193 & 15,582 & 16,753 & 18,202 & 20,700 \\
\hline Gross fixed capital formation & 29,676 & 28,069 & 29,798 & 31,369 & 35,860 \\
\hline Private & 19,590 & 20,340 & 20,463 & 21,590 & 20,965 \\
\hline Public 1/ & 10,086 & 7,729 & 9,335 & 9,779 & 14,895 \\
\hline Increase in stocks & $-1,373$ & 2,576 & $-2,434$ & $-1,197$ & 895 \\
\hline Net exports & $-3,762$ & -672 & 7,827 & 5,233 & 2,990 \\
\hline Exports & 69,099 & 73,841 & 90,463 & 88,301 & 89,080 \\
\hline Goods, f.o.b. & 43,140 & 45,707 & 54,846 & 53,893 & 53,660 \\
\hline Nonfactor services & 25,959 & 28,134 & 35,617 & 34,408 & 35,420 \\
\hline Imports & 72,861 & 74,513 & 82,636 & 83,068 & 86,090 \\
\hline Goods, f.o.b. & 55,498 & 54,483 & 59,037 & 59,326 & 61,045 \\
\hline Nonfactor services & 17,363 & 20,030 & 23,599 & 23,742 & 25,045 \\
\hline GDP at market prices & 107,444 & 119,494 & 132,055 & 141,645 & 156,794 \\
\hline \multicolumn{6}{|l|}{ Memorandum items: } \\
\hline Domestic savings & 24,541 & 29,973 & 35,190 & 35,405 & 39,745 \\
\hline Domestic investment & 28,303 & 30,645 & 27,363 & 30,172 & 36,755 \\
\hline Resource gap & 3,762 & 672 & $-7,827$ & $-5,233$ & $-2,990$ \\
\hline
\end{tabular}

Source: Central Statistics Office, National Accounts of Mauritius.

1/ Includes purchases of ships and/or aircraft in 1999 and 2001. 
Table 5. Mauritius: Real Growth Rates of Gross Domestic Fixed Capital Formation, 1999-2003

(Annual change in percent)

\begin{tabular}{|c|c|c|c|c|c|}
\hline & 1999 & 2000 & 2001 & $\begin{array}{c}2002 \\
\text { Rev. Est. }\end{array}$ & $\begin{array}{l}2003 \\
\text { Prov. }\end{array}$ \\
\hline By type of capital goods & 22.1 & -8.2 & 2.7 & 1.9 & 11.2 \\
\hline Residential building & 3.3 & 7.3 & 5.0 & -5.6 & 15.2 \\
\hline Nonresidential building & 25.9 & 11.2 & -5.7 & 22.3 & 6.2 \\
\hline Other construction and works & 4.8 & 6.0 & 10.0 & 11.4 & 25.6 \\
\hline \multicolumn{6}{|l|}{ Transport equipment } \\
\hline Passenger cars & 2.7 & -2.5 & -2.4 & 19.2 & 6.4 \\
\hline Other equipment $1 /$ & 191.0 & 65.1 & 108.2 & 47.2 & 45.4 \\
\hline Machinery and other equipment & 17.9 & -8.1 & -11.0 & 5.1 & 1.1 \\
\hline By industrial sector & 22.1 & -8.2 & 2.7 & 1.9 & 11.2 \\
\hline \multicolumn{6}{|l|}{ Agriculture, forestry, hunting, } \\
\hline and fishing & 4.1 & -22.2 & -9.5 & 23.9 & -6.4 \\
\hline Manufacturing & 5.6 & 0.0 & -5.6 & 8.1 & 0.7 \\
\hline Of which: export processing zone & 13.0 & -5.8 & -0.5 & -18.5 & 6.4 \\
\hline Electricity, gas and water & 11.7 & -28.8 & -19.6 & -17.1 & 43.5 \\
\hline Construction & -4.2 & 8.0 & -19.1 & -49.9 & 108.2 \\
\hline Wholesale and retail trade & 9.7 & 13.7 & -8.5 & 15.6 & -3.6 \\
\hline Restaurants and hotels & 64.1 & -0.2 & -2.9 & 32.8 & -35.8 \\
\hline \multicolumn{6}{|l|}{ Transport, storage, and } \\
\hline communications $1 /$ & 86.0 & -39.9 & 39.4 & -31.0 & 28.1 \\
\hline Financial intermediation & -6.9 & -16.0 & 21.4 & 33.8 & -12.2 \\
\hline \multicolumn{6}{|l|}{ Real estate, renting, } \\
\hline and business activities & 4.4 & 8.4 & 0.1 & -3.7 & 19.8 \\
\hline Ownership of dwellings & 3.3 & 7.3 & 5.0 & -5.6 & 15.2 \\
\hline Other & 12.9 & 15.9 & -32.1 & 15.1 & 114.8 \\
\hline \multicolumn{6}{|l|}{ Public administration, defense, and } \\
\hline cumpulsory social security & 36.6 & -3.7 & -13.1 & 41.8 & 16.3 \\
\hline Education & -16.6 & 9.7 & -0.6 & 96.7 & 18.5 \\
\hline Health and social work & -28.3 & 45.8 & -8.8 & 76.2 & -5.6 \\
\hline Other services & -31.9 & 147.4 & 12.0 & 9.4 & 53.2 \\
\hline
\end{tabular}

Source: Central Statistics Office, National Accounts of Mauritius.

1/ Includes purchases of ships and/or aircraft. 
Table 6. Mauritius: Composition of Gross Domestic Fixed Capital Formation at Current Prices, 1999-2003

\begin{tabular}{|c|c|c|c|c|c|}
\hline & 1999 & 2000 & 2001 & $\begin{array}{c}2002 \\
\text { Rev. Est. }\end{array}$ & $\begin{array}{c}2003 \\
\text { Prov }\end{array}$ \\
\hline & \multicolumn{5}{|c|}{ (In millions of Mauritian rupees) } \\
\hline By type of capital goods & 29,676 & 28,069 & 29,798 & 31,369 & 35,860 \\
\hline Residential building & 5,460 & 6,035 & 6,525 & 6,408 & 7,605 \\
\hline Nonresidential building & 5,066 & 5,802 & 5,635 & 7,170 & 7,845 \\
\hline Other construction and works & 3,050 & 3,330 & 3,774 & 4,371 & 5,655 \\
\hline Transport equipment & 5,417 & 2,792 & 4,511 & 3,297 & 4,215 \\
\hline Passenger cars & 1,310 & 1,316 & 1,330 & 1,601 & 1,725 \\
\hline Other equipment 1 / & 4,107 & 1,476 & 3,181 & 1,696 & 2,490 \\
\hline Machinery and other equipment & 10,683 & 10,110 & 9,353 & 10,123 & 10,540 \\
\hline By industrial sector & 29,676 & 28,069 & 29,798 & 31,369 & 35,860 \\
\hline \multicolumn{6}{|l|}{ Agriculture, forestry, hunting, } \\
\hline and fishing & 864 & 692 & 648 & 827 & 795 \\
\hline Manufacturing & 4,332 & 4,464 & 4,372 & 4,872 & 5,045 \\
\hline Of which: export processing zone & 1,755 & 1,702 & 1,758 & 1,475 & 1,615 \\
\hline Electricity, gas and water & 2,616 & 1,918 & 1,594 & 1,371 & 2,025 \\
\hline Construction & 545 & 606 & 509 & 260 & 555 \\
\hline \multicolumn{6}{|c|}{ Wholesale and retail trade, repairs and personal } \\
\hline and household services & 1,932 & 2,263 & 2,140 & 2,551 & 2,520 \\
\hline Hotels and restaurants & 2,837 & 2,915 & 2,920 & 4,023 & 2,660 \\
\hline \multicolumn{6}{|l|}{ Transport, storage, and } \\
\hline communications 1 / & 7,321 & 4,533 & 6,547 & 4,640 & 6,080 \\
\hline Financial intermediation & 629 & 544 & 684 & 942 & 850 \\
\hline \multicolumn{6}{|l|}{ Real estate, renting, } \\
\hline and business activities & 6,219 & 6,941 & 7,162 & 7,159 & 9,260 \\
\hline Ownership of dwellings & 5,460 & 6,035 & 6,525 & 6,408 & 7,605 \\
\hline Other & 759 & 906 & 637 & 751 & 1,655 \\
\hline \multicolumn{6}{|l|}{ Public administration, defense, and } \\
\hline cumpulsory social security & 1,288 & 1,278 & 1,146 & 1,680 & 2,010 \\
\hline Education & 440 & 497 & 510 & 1,041 & 1,270 \\
\hline Health and social work & 235 & 353 & 334 & 607 & 590 \\
\hline \multirow[t]{2}{*}{ Other services } & 418 & 1,065 & 1,232 & 1,396 & 2,200 \\
\hline & \multicolumn{5}{|c|}{ (In percent of total) } \\
\hline By type of capital goods & 100.0 & 100.0 & 100.0 & 100.0 & 100.0 \\
\hline Residential building & 18.4 & 21.5 & 21.9 & 20.4 & 21.2 \\
\hline Nonresidential building & 17.1 & 20.7 & 18.9 & 22.9 & 21.9 \\
\hline Other construction and works & 10.3 & 11.9 & 12.7 & 13.9 & 15.8 \\
\hline Transport equipment & 18.3 & 9.9 & 15.1 & 10.5 & 11.8 \\
\hline Passenger cars & 4.4 & 4.7 & 4.5 & 5.1 & 4.8 \\
\hline Other equipment $1 /$ & 13.8 & 5.3 & 10.7 & 5.4 & 6.9 \\
\hline Machinery and other equipment & 36.0 & 36.0 & 31.4 & 32.3 & 29.4 \\
\hline By industrial sector & 100.0 & 100.0 & 100.0 & 100.0 & 100.0 \\
\hline \multicolumn{6}{|l|}{ Agriculture, forestry, hunting, } \\
\hline and fishing & 2.9 & 2.5 & 2.2 & 2.6 & 2.2 \\
\hline Manufacturing & 14.6 & 15.9 & 14.7 & 15.5 & 14.1 \\
\hline Uf which: export processing zone & 5.9 & 6.1 & 5.9 & 4.7 & 4.5 \\
\hline Electricity, gas and water & 8.8 & 6.8 & 5.3 & 4.4 & 5.6 \\
\hline Construction & 1.8 & 2.2 & 1.7 & 0.8 & 1.5 \\
\hline Wholesale and retail trade & 6.5 & 8.1 & 7.2 & 8.1 & 7.0 \\
\hline Restaurants and hotels & 9.6 & 10.4 & 9.8 & 12.8 & 7.4 \\
\hline \multicolumn{6}{|l|}{ Transport, storage, and } \\
\hline communications $1 /$ & 24.7 & 16.1 & 22.0 & 14.8 & 17.0 \\
\hline Financial intermediation & 2.1 & 1.9 & 2.3 & 3.0 & 2.4 \\
\hline \multicolumn{6}{|l|}{ Real estate, renting, } \\
\hline and business activities & 21.0 & 24.7 & 24.0 & 22.8 & 25.8 \\
\hline Ownership of dwellings & 18.4 & 21.5 & 21.9 & 20.4 & 21.2 \\
\hline Other & 2.6 & 3.2 & 2.1 & 2.4 & 4.6 \\
\hline \multicolumn{6}{|l|}{ Public administration, defense, and } \\
\hline cumpulsory social security & 4.3 & 4.6 & 3.8 & 5.4 & 5.6 \\
\hline Education & 1.5 & 1.8 & 1.7 & 3.3 & 3.5 \\
\hline Health and social work & 0.8 & 1.3 & 1.1 & 1.9 & 1.6 \\
\hline Other services & 1.4 & 3.8 & 4.1 & 4.5 & 6.1 \\
\hline
\end{tabular}

Source: Central Statıstics Ottice, National Accounts of Mauritius.

1/ Includes purchases of ships and/or aircraft. 
Table 7. Mauritius: Sugar Cultivation, Yields, and Output, 1999-2003

(Area in thousands of arpents; yields in metric tons per arpent harvested; and production, accruals, and consumption in thousands of metric tons, unless otherwise indicated) $1 /$

\begin{tabular}{|c|c|c|c|c|c|}
\hline & 1999 & 2000 & $\begin{array}{r}2001 \\
\text { Rev. }\end{array}$ & $\begin{array}{r}2002 \\
\text { Rev. Est. }\end{array}$ & $\begin{array}{l}2003 \\
\text { Prov. }\end{array}$ \\
\hline Area under cultivation & 187.1 & 182.3 & 181.2 & 178.9 & $\ldots$ \\
\hline Miller-planters 2/ & 86.6 & 91.9 & 91.6 & 76.6 & $\ldots$ \\
\hline Planters & 100.5 & 90.4 & 89.6 & 102.3 & $\ldots$ \\
\hline Area harvested 3/ & 171.7 & 173.1 & 173.4 & 171.2 & 169.7 \\
\hline Miller-planters 2/ & 78.7 & 85.0 & 84.1 & 70.2 & 67.0 \\
\hline Planters & 93.0 & 88.1 & 89.3 & 101.0 & 102.7 \\
\hline Percent harvested & 91.8 & 95.0 & 95.7 & 95.7 & $\ldots$ \\
\hline Miller-planters 2/ & 90.9 & 92.5 & 91.8 & 91.6 & $\ldots$ \\
\hline Planters & 92.5 & 97.5 & 99.7 & 98.7 & $\ldots$ \\
\hline Cane yield & 22.6 & 29.5 & 33.4 & 28.5 & 30.6 \\
\hline Miller-planters 2/ & 28.0 & 33.9 & 37.3 & 32.7 & 34.5 \\
\hline Planters & 18.1 & 25.3 & 39.7 & 25.6 & 28.1 \\
\hline Cane production & $3,882.0$ & $5,109.0$ & $5,792.0$ & $4,874.0$ & $5,199.0$ \\
\hline Miller-planters 2/ & $2,203.0$ & $2,878.0$ & $3,139.0$ & $2,293.0$ & $2,308.7$ \\
\hline Planters & $1,679.0$ & $2,231.0$ & $2,653.0$ & $2,581.0$ & $2,890.3$ \\
\hline $\begin{array}{l}\text { Commercial sugar recovered } \\
\text { (percent of cane) }\end{array}$ & 9.6 & 11.1 & 11.1 & 10.7 & 10.3 \\
\hline Sugar yield & 2.2 & 3.3 & 3.7 & 3.0 & 3.2 \\
\hline Sugar production & 373.4 & 569.3 & 645.0 & 520.9 & 537.2 \\
\hline White & 2.4 & 3.1 & 5.0 & 7.1 & 0.5 \\
\hline Raw & 371.0 & 566.2 & 640.0 & 513.8 & 536.7 \\
\hline Sugar accruals 4/ & 373.3 & 569.3 & 645.0 & 520.9 & 537.2 \\
\hline Planters & $\ldots$ & $\ldots$ & $\ldots$ & $\ldots$ & $\ldots$ \\
\hline Miller-planters 5/ & $\ldots$ & $\ldots$ & $\ldots$ & $\ldots$ & $\ldots$ \\
\hline Millers & $\ldots$ & $\ldots$ & $\ldots$ & $\ldots$ & $\ldots$ \\
\hline Molasses production & 124.7 & 144.0 & 174.0 & 140.8 & 160.0 \\
\hline \multicolumn{6}{|l|}{ Memorandum items: } \\
\hline Sugar production by fiscal year $5 / 6 /$ & 619.1 & 389.0 & 583.9 & 615.3 & $\ldots$ \\
\hline Of which: local consumption $5 / 7 /$ & 3.7 & 0.0 & 0.0 & 26.4 & $\ldots$ \\
\hline
\end{tabular}

Sources: Mauritius Chamber of Agriculture; Central Statistics Office; and IMF staff estimates.

$1 /$ One arpent $=1.043$ acres, or 0.4221 hectare.

2/ Mills and estates, including legally separate companies under same ownership.

3/ Difference from area cultivated is attributable mainly to replanting and rotational/fallow periods.

4/ Reflects millers' 26 percent share of sugar produced as compensation for milling, as adjusted for mill efficiency.

5/ Fiscal-year data relate to 12-month period ending in June of current year.

6/ Total crop from harvest beginning approximately one month before the start of the fiscal year indicated, less the output in June immediately before the indicated fiscal year, plus the June output of the next crop, most of which is produced in the next fiscal year.

7/ During 2001/02, 17,050 tons of sugar were imported for local consumption. Imports for the 2002/03 period were 32,000 tons for local consumption. 
Table 8. Mauritius: Sugar Exports, 1998/99-2002/03 1/

\begin{tabular}{|c|c|c|c|c|c|}
\hline & 1998/99 & $1999 / 00$ & $2000 / 01$ & $2001 / 02$ & $\begin{array}{l}2002 / 03 \\
\text { Rev. Est. }\end{array}$ \\
\hline & \multicolumn{5}{|c|}{ (In thousands of metric tons) } \\
\hline Volume shipped & 628.5 & 378.5 & 565.0 & 589.9 & 515.0 \\
\hline European Union & 524.8 & 368.8 & 540.0 & 520.0 & 484.9 \\
\hline United States & 18.5 & 6.0 & 5.0 & 19.8 & 1.9 \\
\hline World market & 4.5 & 3.7 & 6.0 & 6.5 & 6.4 \\
\hline \multirow[t]{2}{*}{ Special Preferential Sugar Agreement 2/ } & 80.7 & 0.0 & 14.0 & 43.6 & 21.8 \\
\hline & \multicolumn{5}{|c|}{ (Mauritian rupees per metric ton) } \\
\hline Unit value & 14,691 & 14,267 & 12,844 & 14,657 & 16,061 \\
\hline European Union & 15,166 & 14,284 & 12,900 & 14,877 & 16,232 \\
\hline United States & 12,703 & 16,167 & 17,600 & 13,333 & 15,789 \\
\hline World market & 9,111 & 9,459 & 9,667 & 10,769 & 11,188 \\
\hline \multirow[t]{2}{*}{ Special Preferential Sugar Agreement 2/ } & 12,367 & 0 & 10,357 & 13,211 & 13,716 \\
\hline & \multicolumn{5}{|c|}{ (In millions of Mauritian rupees) } \\
\hline Value, f.o.b. & 9,233 & 5,400 & 7,257 & 8,646 & 8,272 \\
\hline European Union & 7,959 & 5,268 & 6,966 & 7,736 & 7,871 \\
\hline United States & 235 & 97 & 88 & 264 & 30 \\
\hline World market & 41 & 35 & 58 & 70 & 72 \\
\hline \multirow[t]{2}{*}{ Special Preferential Sugar Agreement 2/ } & 998 & 0 & 145 & 576 & 299 \\
\hline & \multicolumn{5}{|c|}{ (U.S. dollars per metric ton) } \\
\hline Unit value & 591.9 & 559.2 & 465.5 & 487.0 & 563.6 \\
\hline European Union & 611.1 & 559.9 & 467.6 & 494.3 & 569.6 \\
\hline United States & 511.8 & 633.7 & 637.9 & 443.0 & 554.0 \\
\hline World market & 367.1 & 370.8 & 350.4 & 357.8 & 392.5 \\
\hline \multirow[t]{2}{*}{ Special Preferential Sugar Agreement 2/ } & 498.3 & $\ldots$ & 375.4 & 439.0 & 481.2 \\
\hline & \multicolumn{5}{|c|}{ (In millions of U.S. dollars) } \\
\hline Value, f.o.b. & 372.0 & 211.7 & 263.0 & 287.3 & 290.2 \\
\hline European Union & 320.7 & 206.5 & 252.5 & 257.1 & 276.2 \\
\hline United States & 9.5 & 3.8 & 3.2 & 8.8 & 1.1 \\
\hline World market & 1.7 & 1.4 & 2.1 & 2.3 & 2.5 \\
\hline \multirow[t]{2}{*}{ Special Preferential Sugar Agreement 2/ } & 40.2 & $\ldots$ & 5.3 & 19.1 & 10.5 \\
\hline & \multicolumn{5}{|c|}{ (Mauritian rupees per U.S. dollars) } \\
\hline Conversion factor & 24.819 & 25.512 & 27.591 & 30.095 & 28.500 \\
\hline
\end{tabular}

Sources: Mauritius Sugar Syndicate (MSS); and Bank of Mauritius.

1/ Fiscal year from July to June. Data differ somewhat from those presented by the MSS on a crop-year basis, which refer to disposal of a given year's crop (from June when harvest starts, to the following June).

2/ The Special Preferential Sugar Agreement was signed on June 1, 1995 between Atlantic, Caribbean, and Pacific (ACP) sugar-supplying countries and the European Union to compensate for the European cane refiners' deficit for a period of six years, to 2001. It provides Mauritius with the right to export a variable tonnage of approximately 80,000 tons of sugar. 
Table 9. Mauritius: Ex-Syndicate Sugar Prices, 1998/99-2002/03 1/

\section{(Mauritian rupees per ton)}

\begin{tabular}{|c|c|c|c|c|c|}
\hline & 1998/99 & 1999/00 & $2000 / 01$ & $2001 / 02$ & $\begin{array}{r}\text { 2002/03 } \\
\text { Rev. Est. }\end{array}$ \\
\hline Average sugar prices (ex-millers) & 13,250 & 12,374 & 11,570 & 12,835 & 14,047 \\
\hline Average price, after taxes and crop insurance premiums & 12,064 & 12,374 & 11,570 & 12,835 & 14,047 \\
\hline \multicolumn{6}{|l|}{ Memorandum items: } \\
\hline Average SIFB insurance premiums & 1,166 & 1,797 & 1,048 & 1,123 & 1,531 \\
\hline Bagasse proceeds $2 /$ & 66 & 120 & 97 & 100 & 125 \\
\hline
\end{tabular}

Source: Mauritius Sugar Syndicate.

1/ Marketing years.

2/ Paid to planters but not to millers. 
Table 10. Mauritius: Revenue and Expenditure of Sugar Estates with Factories, 1999-2003 1/ 2/

(In millions of Mauritian rupees, unless otherwise indicated)

\begin{tabular}{|c|c|c|c|c|c|}
\hline & 1999 & 2000 & 2001 & $\begin{array}{r}2002 \\
\text { Est. }\end{array}$ & $\begin{array}{l}2003 \\
\text { Prov. }\end{array}$ \\
\hline Production and prices & \multicolumn{5}{|c|}{$\begin{array}{l}\text { (Production in thousands of metric tons; and } \\
\text { prices in Mauritian rupees per metric ton) }\end{array}$} \\
\hline \multicolumn{6}{|l|}{ Sugar output (at 98.5 polarization) } \\
\hline National total & 374 & 569 & 646 & 521 & 537 \\
\hline Estates with factories & 266 & 396 & 442 & 367 & 371 \\
\hline Sugar price, ex-syndicate $3 /$ & 12,374 & 11,602 & 12,875 & 14,097 & 15,200 \\
\hline \multicolumn{6}{|l|}{ Molasses output } \\
\hline National total & 127 & 146 & 175 & 141 & 160 \\
\hline Estates with factories & 79 & 90 & 105 & 87 & 99 \\
\hline \multirow[t]{2}{*}{ Molasses price } & 145 & 436 & 902 & 599 & 350 \\
\hline & \multicolumn{5}{|c|}{ (In millions of Mauritian rupees) } \\
\hline Revenue & 4,990 & 5,097 & 6,108 & 5,928 & 6,466 \\
\hline Sugar 3/ & 3,291 & 4,597 & 5,694 & 5,174 & 5,634 \\
\hline Molasses & 11 & 39 & 95 & 52 & 35 \\
\hline $\begin{array}{l}\text { Electricity, white sugar, } \\
\text { and by-products }\end{array}$ & 186 & 267 & 309 & 270 & 422 \\
\hline Crop insurance compensation & 1,502 & 194 & 10 & 432 & 375 \\
\hline Operating expenditure & 4,974 & 5,542 & 5,794 & 5,106 & 5,272 \\
\hline Wages and salaries & 2,622 & 3,042 & 3,130 & 2,269 & 2,326 \\
\hline Agricultural workers & 1367 & 1582 & 1627 & 1180 & 1209 \\
\hline Nonagricultural workers & 690 & 791 & 814 & 590 & 605 \\
\hline Administrative staff & 565 & 669 & 689 & 499 & 512 \\
\hline Supplies and other charges & 1914 & 2071 & 2180 & 2330 & 2360 \\
\hline Supplies & 759 & 806 & 846 & 955 & 965 \\
\hline Interest & 371 & 461 & 496 & 458 & 468 \\
\hline Other charges & 784 & 804 & 838 & 917 & 927 \\
\hline Centralisation costs & 0 & 0 & 0 & 35 & 51 \\
\hline Crop insurance premium and levy & 438 & 429 & 484 & 472 & 535 \\
\hline Operating surplus/deficit (-) & 17 & -445 & 315 & 821 & 1194 \\
\hline VRS - amortization & 0 & 0 & 0 & 0 & -400 \\
\hline Depreciation per accounts (-) & -492 & -475 & -481 & -465 & -469 \\
\hline Profit/loss (-) on sugar & -475 & -920 & -166 & 356 & 325 \\
\hline Net nonsugar income 4/ & 1104 & 641 & 2326 & 900 & 686 \\
\hline Receipts 5/ & 1329 & 914 & 2667 & 1200 & 986 \\
\hline Payments (-) & -225 & -273 & -341 & -300 & -300 \\
\hline Overall profit/loss (-) & 629 & -279 & 2160 & 1256 & 1011 \\
\hline
\end{tabular}


Table 10. Mauritius: Revenue and Expenditure of Sugar Estates with Factories, 1999-2003 1/ 2/ (concluded)

(In millions of Mauritian rupees, unless otherwise indicated)

\begin{tabular}{|c|c|c|c|c|c|}
\hline & 1999 & 2000 & 2001 & $\begin{array}{r}2002 \\
\text { Est. }\end{array}$ & $\begin{array}{l}2003 \\
\text { Prov. }\end{array}$ \\
\hline & \multicolumn{5}{|c|}{ (In millions of Mauritian rupees, unless otherwise indicated) } \\
\hline $\begin{array}{l}\text { Transfer to modernization and } \\
\text { agricultural diversification reserve } 6 /\end{array}$ & -7 & -33 & -32 & -175 & -175 \\
\hline Special levy & 0 & 0 & 0 & 0 & 0 \\
\hline \multicolumn{6}{|l|}{ Memorandum items: } \\
\hline Income taxes & 0 & 0 & 0 & 0 & 0 \\
\hline Depreciation & 0 & 0 & 0 & 0 & 0 \\
\hline Excess over accounts & 0 & 0 & 0 & 0 & 0 \\
\hline Additions to fixed assets & 0 & 0 & 0 & 0 & 0 \\
\hline
\end{tabular}

Sources: Mauritius Chamber of Agriculture; Mauritius Sugar Authority; and IMF staff estimates.

1/ Based on companies' audited accounts, in which accounting practices vary somewhat, supplemented by questionnaire returns.

2/ Accounting-year basis. Mainly calendar years, except Illovo and Mon Trésor (April-March).

Revenues include receipts (partly estimated) from current year's crop through following June 30.

3/ Less Mauritius Sugar Syndicate marketing expenses and cesses; before export taxes and insurance premiums. Reflects actual final price, whereas company accounts are closed using an estimate.

4/ Income on other crops and nonagricultural activities.

5/ Figure does not include additional receipts relating to the Lllovo deal.

6/ Producers are requested to credit an aggregate amount of MUR 175 million to a modernization and agricultural diversification reserve for each of the years 1994-2003. Transfers from this reserve are allowed on approved investments. 
Table 11. Mauritius: Nonsugar Agricultural Production, 1999-2003

(In thousands of metric tons, unless otherwise indicated)

\begin{tabular}{|c|c|c|c|c|c|}
\hline & 1999 & 2000 & $\begin{array}{r}2001 \\
\text { Rev. Est. }\end{array}$ & $\begin{array}{l}2002 \\
\text { Prov. }\end{array}$ & $\begin{array}{l}2003 \\
\text { Prov. }\end{array}$ \\
\hline \multicolumn{6}{|l|}{ Tea } \\
\hline Area harvested (in thousands of arpents) $1 /$ & 1.6 & 1.6 & 1.6 & 1.6 & 1.6 \\
\hline Production & 冫 & 7.6 & 8.9 & 8.4 & 8.3 \\
\hline Green leaf processed & 7.0 & 6.3 & 7.4 & 7.0 & 6.9 \\
\hline Manufactured tea & 1.5 & 1.3 & 1.5 & 1.4 & 1.4 \\
\hline Green leaf yields (tons per hectare) & 10.6 & 9.5 & 11.3 & 11.0 & 10.2 \\
\hline \multicolumn{6}{|l|}{ Food crops } \\
\hline Area harvested (in thousands of arpents) $1 /$ & 14.3 & 17.4 & 18.9 & 18.0 & $\ldots$ \\
\hline Production & 85.7 & 114.5 & 133.5 & 125.0 & $\ldots$ \\
\hline Potatoes & 15.7 & 14.5 & 18.8 & 17.6 & ... \\
\hline Irish & 15.3 & 13.8 & 18.3 & 17.0 & $\ldots$ \\
\hline Sweet & 0.4 & 0.7 & 0.5 & 0.6 & ... \\
\hline Tomatoes & 8.0 & 9.7 & 11.7 & 11.0 & $\ldots$ \\
\hline Eggplant (brinjal) & 1.7 & 2.2 & 2.7 & 2.5 & $\ldots$ \\
\hline Bananas & 7.6 & 8.5 & 10.1 & 7.0 & $\ldots$ \\
\hline Pineapples & 1.0 & 3.4 & 6.0 & 6.0 & $\ldots$ \\
\hline Groundnuts & 0.3 & 0.4 & 0.3 & 0.4 & $\ldots$ \\
\hline Maize 2/ & 0.2 & 0.6 & 0.4 & 0.4 & $\ldots$ \\
\hline Manioc & 0.1 & 0.2 & 0.2 & 0.2 & $\ldots$ \\
\hline Ginger & 0.1 & 0.5 & 0.9 & 1.0 & $\ldots$ \\
\hline Other 3/ & 51.0 & 74.5 & 82.4 & 78.9 & ... \\
\hline
\end{tabular}

Sources: Mauritius Chamber of Agriculture; and Ministry of Agriculture, Food Technology, and Natural Resources.

$1 /$ One arpent $=1.043$ acres, or 0.4221 hectare .

2/ Includes maize that is sent to drying stations; does not include fodder.

3/ Includes beans and peas, eddoes (arouille), creepers (cucumber and squash), and mixed vegetables (beets, cabbage, carrots, cauliflower, chilies, garlic, onions, and lettuce). 
Table 12. Mauritius: Export Processing Zone (EPZ) Activity, 1999-2003

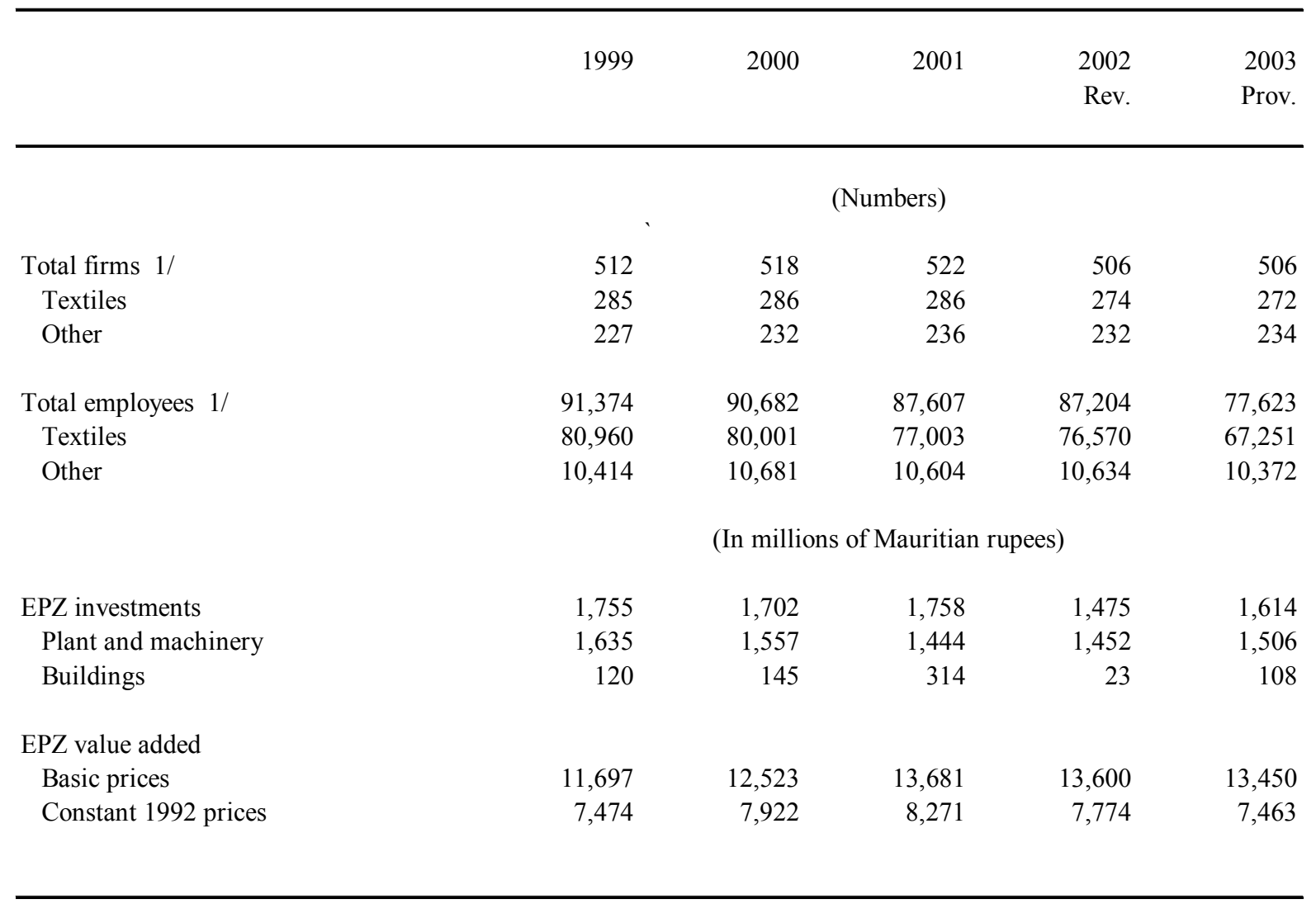

Source: Central Statistics Office, Digest of Industrial Statistics .

1/ As at December. 
Table 13. Mauritius: Electricity Production and Consumption, 1999-2003 1/

\begin{tabular}{|c|c|c|c|c|c|}
\hline & 1999 & 2000 & 2001 & $\begin{array}{r}2002 \\
\text { Rev. Est. } \\
\end{array}$ & $\begin{array}{l}2003 \\
\text { Prov. }\end{array}$ \\
\hline \multirow{3}{*}{ Plant effective capacity } & \multicolumn{5}{|c|}{ (In megawatts) } \\
\hline & 425.7 & 497.9 & 513.5 & 513.5 & 513.5 \\
\hline & \multicolumn{5}{|c|}{ (In percent of total) } \\
\hline Hydroelectric effective capacity & 12.8 & 10.9 & 10.9 & 10.9 & 10.6 \\
\hline Of which: purchases 2/ & 0.1 & 0.1 & 0.1 & 0.1 & 0.1 \\
\hline Thermal effective capacity & 87.2 & 89.1 & 89.1 & 89.1 & 89.4 \\
\hline \multirow[t]{2}{*}{ Of which: purchases 2/ } & 21.2 & 27.2 & 27.2 & 27.2 & 29.4 \\
\hline & \multicolumn{5}{|c|}{ (In millions of kilowatt-hours) } \\
\hline Energy generated & $1,422.6$ & $1,564.9$ & $1,657.1$ & $1,715.1$ & $1,840.0$ \\
\hline Hydroelectric & 29.6 & 95.3 & 70.4 & 85.6 & 117.7 \\
\hline Thermal & $1,393.0$ & $1,469.6$ & $1,586.6$ & $1,629.5$ & $1,722.3$ \\
\hline Energy purchased from sugar and other factories & 343.8 & 601.2 & 710.2 & 746.6 & 729.4 \\
\hline \multirow[t]{2}{*}{ Energy sold } & $1,229.3$ & $1,358.5$ & $1,450.0$ & $1,502.0$ & $1,607.0$ \\
\hline & \multicolumn{5}{|c|}{ (Annual growth in percent, unless otherwise indicated) } \\
\hline Energy generated & 4.2 & 10.0 & 5.9 & 3.5 & 7.3 \\
\hline Energy purchased from sugar and other factories & 34.3 & 74.87 & 18.12 & 5.13 & -2.30 \\
\hline Energy sold & 4.5 & 10.5 & 6.7 & 3.6 & 7.0 \\
\hline Consumers at year's end (numbers) & 304,029 & 313,963 & 323,213 & 330,323 & 338,563 \\
\hline Of which: domestic (percent of total) & 89.2 & 89.1 & 89.2 & 89.2 & 89.3 \\
\hline Annual percentage increase of consumers & 3.5 & 3.3 & 2.9 & 2.2 & 2.5 \\
\hline \multirow[t]{2}{*}{$\begin{array}{l}\text { Average selling prices (Mauritian cents } \\
\text { per kilowatt-hour) }\end{array}$} & 211.0 & 230.0 & 269.0 & 304.1 & 306.0 \\
\hline & \multicolumn{5}{|c|}{ (In millions of Mauritian rupees, unless otherwise indicated) } \\
\hline \multicolumn{6}{|l|}{ Central Electricity Board indicators } \\
\hline Revenue & $2,659.0$ & $3,300.4$ & $4,136.9$ & $4,842.8$ & $5,179.2$ \\
\hline Current expenditure & $2,839.5$ & $3,675.7$ & $3,943.1$ & $4,663.3$ & $4,715.7$ \\
\hline Persons employed (number) & 1,854 & 1,830 & 1,807 & 1,779 & 1,739 \\
\hline
\end{tabular}

Sources: Central Statistics Office; and Central Electricity Board (CEB).

1/ From sugar mills and other factories generating electricity. 
Table 14. Mauritius: Building Permits Issued, 1999-2003 1/

\begin{tabular}{|c|c|c|c|c|c|}
\hline & 1999 & 2000 & 2001 & $\begin{array}{r}2002 \\
\text { Rev. Est. }\end{array}$ & $\begin{array}{l}2003 \\
\text { Prov. }\end{array}$ \\
\hline Permits issued & \multicolumn{5}{|c|}{ (Numbers) } \\
\hline Total & 8,817 & 8,867 & 9,495 & 9,054 & 9,123 \\
\hline \multicolumn{6}{|l|}{ By building type } \\
\hline Residential & 8,280 & 8,331 & 8,999 & 8,671 & 8,712 \\
\hline New buildings & 4,657 & 4,538 & 4,459 & 4,167 & 4,301 \\
\hline Additions & 3,623 & 3,793 & 4,540 & 4,504 & 4,411 \\
\hline Nonresidential & 537 & 536 & 496 & 383 & 411 \\
\hline \multicolumn{6}{|l|}{ By location } \\
\hline Urban & 4,437 & 3,856 & 3,903 & 3,689 & 3,723 \\
\hline Rural & 4,380 & 5,011 & 5,592 & 5,365 & 5,400 \\
\hline Floor area & \multicolumn{5}{|c|}{ (Thousands of square meters) } \\
\hline Total & 1,546 & 1,510 & 1,504 & 1,542 & 1,638 \\
\hline \multicolumn{6}{|l|}{ By building type } \\
\hline Residential & 1,244 & 1,170 & 1,256 & 1,222 & 1,230 \\
\hline New buildings & 865 & 785 & 794 & 758 & 769 \\
\hline Additions & 379 & 385 & 462 & 464 & 461 \\
\hline Nonresidential & 302 & 340 & 248 & 320 & 408 \\
\hline \multicolumn{6}{|l|}{ By location } \\
\hline Urban & 731 & 592 & 646 & 651 & 677 \\
\hline Rural & 815 & 918 & 858 & 891 & 961 \\
\hline
\end{tabular}

Source: Central Statistics Office.

1/ Includes new buildings and additions for which permits have been issued by municipalities and the central government. 
Table 15. Mauritius: Tourist Arrivals, Capacity, and Earnings, 1999-2003

\begin{tabular}{|c|c|c|c|c|c|}
\hline & 1999 & 2000 & 2001 & $\begin{array}{c}2002 \\
\text { Rev. Est. }\end{array}$ & $\begin{array}{c}2003 \\
\text { Prov. }\end{array}$ \\
\hline \multicolumn{6}{|l|}{ Arrivals by country of residence } \\
\hline Africa & 156,314 & 163,921 & 168,522 & 172,641 & 174,430 \\
\hline Kenya & 1,655 & 1,801 & 1,734 & 1,507 & 1,510 \\
\hline Madagascar & 7,880 & 7,057 & 6,674 & 9,417 & 11,044 \\
\hline Reunion (France) & 83,749 & 86,945 & 91,140 & 96,375 & 95,679 \\
\hline Seychelles & 7,893 & 9,229 & 10,687 & 13,468 & 9,869 \\
\hline South Africa & 46,583 & 48,683 & 47,882 & 42,685 & 45,756 \\
\hline Zimbabwe & 2,606 & 3,435 & 3,860 & 3,185 & 2,343 \\
\hline Other Africa & 5,948 & 6,771 & 6,545 & 6,004 & 8,229 \\
\hline Europe & 378,741 & 439,989 & 437,305 & 451,504 & 465,379 \\
\hline Belgium & 9,586 & 10,998 & 10,398 & 10,579 & 10,170 \\
\hline France & 175,431 & 198,423 & 197,595 & 202,869 & 200,229 \\
\hline Germany & 45,206 & 52,869 & 50,866 & 53,762 & 53,970 \\
\hline Italy & 36,675 & 39,000 & 37,343 & 38,263 & 39,774 \\
\hline Switzerland & 16,281 & 20,473 & 18,427 & 17,371 & 17,929 \\
\hline United Kingdom & 58,683 & 74,488 & 77,888 & 80,667 & 91,210 \\
\hline Other Europe & 36,879 & 43,738 & 44,788 & 47,993 & 52,097 \\
\hline Other & 43,030 & 52,543 & 54,491 & 57,503 & 62,209 \\
\hline Australia & 8,076 & 8,771 & 8,790 & 8,387 & 9,103 \\
\hline India & 13,583 & 17,241 & 18,890 & 20,898 & 25,367 \\
\hline Japan & 2,324 & $2,389.00$ & $1,589.00$ & $1,958.00$ & $1,572.00$ \\
\hline Singapore & 3661.0 & 4104.0 & 3431.0 & 3114.0 & 2102.0 \\
\hline United States & 3345.0 & 3704.0 & 3923.0 & 4116.0 & 4505.0 \\
\hline Other & 12041.0 & 16334.0 & 17868.0 & 19030.0 & 19560.0 \\
\hline All countries & 578,085 & 656,453 & 660,318 & 681,648 & 702,018 \\
\hline \multicolumn{6}{|l|}{$\begin{array}{l}\text { Tourism capacity, occupancy, activity, } \\
\text { and earnings }\end{array}$} \\
\hline Hotels & 92 & 95 & 95 & 95 & 97 \\
\hline Rooms & 8,255 & 8,657 & 9,024 & 9,623 & 9,647 \\
\hline Beds & 16,947 & 17,776 & 18,350 & 19,597 & 19,727 \\
\hline \multicolumn{6}{|c|}{ Occupancy rates for all hotels (percent) } \\
\hline Room & $\ldots$ & 70 & 66 & 67 & 63 \\
\hline Bed & $\ldots$ & 62 & 58 & 59 & 55 \\
\hline Nights spent (thousands) & 5,729 & 6,413 & 6,528 & 6,769 & 6,952 \\
\hline Average stay (nights) & 10 & 10 & 10 & 10 & 10 \\
\hline \multicolumn{6}{|l|}{ Gross earnings } \\
\hline In millions of Mauritian rupees & 13,668 & 14,234 & 18,166 & 18,328 & 19,397 \\
\hline In millions of U.S. dollars & 543 & 542 & 624 & 612 & 695 \\
\hline \multicolumn{6}{|l|}{ Average earnings per tourist } \\
\hline In Mauritian rupees & 23,644 & 21,683 & 27,511 & 26,888 & 27,630 \\
\hline In U.S. dollars & 939 & 826 & 944 & 897 & 974 \\
\hline
\end{tabular}


Table 16. Mauritius: Estimated Labor Force and Employment, 1999-2003 1/

\begin{tabular}{|c|c|c|c|c|c|}
\hline & 1999 & 2000 & 2001 & $\begin{array}{r}2002 \\
\text { Rev. Est. }\end{array}$ & $\begin{array}{l}2003 \\
\text { Prov. }\end{array}$ \\
\hline & \multicolumn{5}{|c|}{ (In thousands of persons) } \\
\hline Population aged $12+$ years $2 /$ & 925.9 & 937.6 & 951.2 & 963.7 & 977.0 \\
\hline Female & 469.1 & 475.7 & 482.8 & 489.4 & 496.0 \\
\hline Male & 456.8 & 461.9 & 468.4 & 474.3 & 481.0 \\
\hline Labor force & 519.5 & 528.6 & 538.5 & 541.1 & 549.3 \\
\hline Female & 177.1 & 181.4 & 186.4 & 187.4 & 190.3 \\
\hline Mauritian & 168.6 & 171.8 & 175.7 & 176.8 & 180.0 \\
\hline Foreign & 8.5 & 9.6 & 10.7 & 10.6 & 10.3 \\
\hline Male & 342.4 & 347.2 & 352.1 & 353.7 & 359.0 \\
\hline Mauritian & 338.0 & 342.2 & 346.3 & 347.3 & 351.1 \\
\hline Foreign & 4.4 & 5.0 & 5.8 & 6.4 & 7.9 \\
\hline Employment & 480.5 & 483.6 & 490.8 & 490.1 & 494.9 \\
\hline Large establishments 3/ 4/ & 297.4 & 297.7 & 301.0 & 296.2 & 295.9 \\
\hline Of which: foreign & 12.9 & 14.6 & 16.5 & 17.0 & 18.2 \\
\hline Female & 109.7 & 110.5 & 113.0 & 108.3 & 108.0 \\
\hline Male & 187.7 & 187.2 & 188.0 & 187.9 & 187.9 \\
\hline Other firms and self & 183.1 & 185.9 & 189.8 & 193.9 & 199.0 \\
\hline Female & 52.2 & 54.4 & 56.2 & 57.8 & 59.6 \\
\hline Male & 130.9 & 131.5 & 133.6 & 136.1 & 139.4 \\
\hline \multicolumn{6}{|l|}{ Employment in large establishments } \\
\hline by economic activity $4 / 5 /$ & 297.7 & 297.0 & 301.2 & 294.4 & 298.5 \\
\hline Agriculture, forestry, and fishing & 34.3 & 32.7 & 31.3 & 25.3 & 23.4 \\
\hline Of which: sugar & 0.0 & 24.8 & 23.5 & 17.6 & 15.5 \\
\hline Mining and quarrying & 0.2 & 0.2 & 0.2 & 0.2 & 0.2 \\
\hline Manufacturing & 115.6 & 115.0 & 117.0 & 111.0 & 108.9 \\
\hline Of which: sugar & 3.9 & 3.4 & 3.2 & 3.1 & 2.2 \\
\hline Of which: EPZ 6/ & 88.9 & 88.2 & 90.8 & 84.5 & 82.5 \\
\hline Electricity, gas, and water & 3.1 & 3.0 & 3.0 & 3.0 & 3.0 \\
\hline Construction & 13.6 & 13.5 & 13.3 & 13.3 & 14.6 \\
\hline Wholesale and retail trade & 16.4 & 16.5 & 16.5 & 16.5 & 17.7 \\
\hline Hotels and restaurants & 13.0 & 14.5 & 16.3 & 17.1 & 18.2 \\
\hline \multicolumn{6}{|l|}{ Transport, storage, and } \\
\hline communications & 16.4 & 16.1 & 16.6 & 17.5 & 18.1 \\
\hline Financial intermediation & 6.6 & 6.7 & 7.1 & 7.0 & 7.4 \\
\hline \multicolumn{6}{|l|}{ Real estate, renting, and } \\
\hline business activities & 8.3 & 8.9 & 8.9 & 8.7 & 8.9 \\
\hline Public administration and defense & 34.8 & 34.9 & 35.7 & 37.8 & 38.9 \\
\hline Education & 17.9 & 17.8 & 18.3 & 18.9 & 20.6 \\
\hline Health and social work & 11.4 & 11.3 & 11.0 & 11.0 & 11.6 \\
\hline \multicolumn{6}{|l|}{ Other community, social, and } \\
\hline personal service & 6.2 & 6.0 & 6.2 & 7.1 & 7.0 \\
\hline Unemployment & 39.0 & 45.0 & 47.7 & 51.0 & 54.4 \\
\hline Female & 15.2 & 16.5 & 17.2 & 21.3 & 22.7 \\
\hline Male & 23.8 & 28.5 & 30.5 & 29.7 & 31.7 \\
\hline
\end{tabular}


Table 16. Mauritius: Estimated Labor Force and Employment, 1999-2003 1/(concluded)

\begin{tabular}{|c|c|c|c|c|c|}
\hline & 1999 & 2000 & 2001 & $\begin{array}{r}2002 \\
\text { Rev. Est. }\end{array}$ & $\begin{array}{l}2003 \\
\text { Prov. }\end{array}$ \\
\hline & \multicolumn{5}{|c|}{ (In percent) } \\
\hline Labor force participation rate & 56.1 & 56.4 & 56.6 & 56.1 & 56.2 \\
\hline Female & 37.8 & 38.1 & 38.6 & 38.3 & 38.4 \\
\hline Male & 75.0 & 75.2 & 75.2 & 74.6 & 74.6 \\
\hline Unemployment rate & 7.7 & 8.8 & 9.1 & 9.7 & 10.2 \\
\hline Female & 9.0 & 9.6 & 9.8 & 12.0 & 12.6 \\
\hline Male & 7.0 & 8.3 & 8.8 & 8.6 & 9.0 \\
\hline Employment growth rate & 1.2 & 0.6 & 1.5 & -0.1 & 1.0 \\
\hline Female & 2.5 & 1.9 & 2.6 & -1.8 & 0.9 \\
\hline Male & 0.5 & 0.0 & 0.9 & 0.7 & 1.0 \\
\hline
\end{tabular}

Source: Central Statistics Office, Survey of Employment and Earnings and Digest of Labour Statistics.

1/ Data are for the islands of Mauritius and Rodrigues.

2/ Includes foreigners.

3/ Average of March and September survey results.

4/ Covers large establishments, i.e., nonagricultural establishments with ten or more employees, all government, sugar plantations of ten hectares or more, tea plantations of two hectares or more, all flue-cured tobacco, and other agricultural units with ten or more employees; excludes self-employed, piece-rate employees working at home, and unpaid family workers. Includes foreign workers.

5/ At March of each year.

6/ Excludes nonmanufacturing EPZ establishments. 
Table 17. Mauritius: Average Earnings by Sector — Monthly Paid Employees, 1999-2003 1/

(Mauritian rupees per employee per month)

\begin{tabular}{|c|c|c|c|c|c|}
\hline & 1999 & 2000 & 2001 & $\begin{array}{r}2002 \\
\text { Rev. Est. }\end{array}$ & $\begin{array}{l}2003 \\
\text { Prov. }\end{array}$ \\
\hline Agriculture, forestry, and fishing & 6,146 & 6,818 & 7,910 & 8,527 & 9,374 \\
\hline Of which: sugar & 5,625 & 6,268 & 7,116 & 7,753 & 8,826 \\
\hline Mining and quarrying & 10,905 & 11,427 & 12,822 & 13,396 & 8,906 \\
\hline Manufacturing & 7,105 & 7,703 & 8,127 & 8,566 & 9,430 \\
\hline Of which: export processing zone (EPZ) & 6,423 & 6,944 & 7,194 & 7,821 & 8,542 \\
\hline Electricity, gas, and water & 12,157 & 13,569 & 15,696 & 17,519 & 18,987 \\
\hline Construction & 8,884 & 10,232 & 10,278 & 11,218 & 12,216 \\
\hline Wholesale and retail trade & 9,098 & 9,787 & 10,780 & 10,958 & 11,486 \\
\hline Hotels and restaurants & 7,099 & 7,437 & 7,819 & 8,056 & 8,444 \\
\hline $\begin{array}{l}\text { Transport, storage, and } \\
\text { communications }\end{array}$ & 10,508 & 12,021 & 12,508 & 13,377 & 14,484 \\
\hline Financial intermediation & 13,515 & 14,814 & 16,538 & 17,230 & 17,817 \\
\hline Real estate, renting, and business activities & 9,937 & 11,321 & 12,301 & 12,499 & 13,682 \\
\hline Public administration and defense & 9608.0 & 10208 & 10684 & 11022 & 11256 \\
\hline Education & 10,608 & 11,256 & 11,235 & 11,682 & 12,458 \\
\hline Health and social work & 10,137 & 11,290 & 12,396 & 12,128 & 12,900 \\
\hline Other community, social, and personal service & 8,287 & 8,364 & 8,683 & 8,315 & 9,385 \\
\hline Total, large establishments & 8,080 & 9,579 & 10,216 & 10,686 & 11,439 \\
\hline Of which: EPZ & 6,428 & 6,955 & 7,242 & 7,850 & 8,617 \\
\hline \multicolumn{6}{|l|}{ Memorandum items: } \\
\hline Daily paid employees $2 /$ & 4,810 & 5,174 & 5,460 & 5,668 & 6,162 \\
\hline Of which: EPZ 2/ & 3,926 & 4,134 & 4,498 & 4,628 & 4,914 \\
\hline
\end{tabular}

Source: Central Statistics Office, Survey of Employment and Earnings in 'large' establishments.

1/ Covers large establishments. Employees paid monthly account for approximately two-thirds of such employment and four-fifths of earnings reported.

2/ Daily earnings converted to a monthly basis by assuming 26 working days in a month. 
Table 18. Mauritius: Labor Costs and Productivity, 1999-2003 1/

(Indices, 1982=100)

\begin{tabular}{|c|c|c|c|c|c|}
\hline & 1999 & 2000 & 2001 & $\begin{array}{r}2002 \\
\text { Rev. Est. }\end{array}$ & $\begin{array}{l}2003 \\
\text { Prov. }\end{array}$ \\
\hline Labor cost (1) & 859.0 & 923.5 & 993.0 & $1,059.0$ & $1,174.4$ \\
\hline Real output (2) & 248.2 & 271.3 & 286.5 & 291.9 & 304.8 \\
\hline Employment (3) 2/ & 167.6 & 169.4 & 170.6 & 171.3 & 173.5 \\
\hline Consumer price index (4) & 315.8 & 328.5 & 346.3 & 368.4 & 382.8 \\
\hline $\begin{array}{l}\text { Unit labor cost } \\
\qquad(5)=(1) /(2)\end{array}$ & 346.1 & 340.4 & 346.6 & 362.8 & 385.3 \\
\hline $\begin{array}{l}\text { Average real wage } 3 / \\
\quad(6)=(1) /\left[(3)^{*}(4)\right]\end{array}$ & 162.3 & 166.0 & 168.1 & 167.8 & 176.8 \\
\hline $\begin{array}{l}\text { Labor productivity } \\
\qquad(7)=(2) /(3)\end{array}$ & 148.1 & 160.2 & 167.9 & 170.4 & 175.7 \\
\hline
\end{tabular}

Source: Central Statistics Office, Digest of Productivity and Competitiveness Statistics.

1/ Total economy.

2/ Number of persons.

3/ Covers the overall compensation of employees, including wages, salaries, overtime, bonuses, and contributions to pension funds. 
Table 19. Mauritius: Cost Structure and Prices of Petroleum Products, 1998/99-2002/03 1/

(In percent of the sales price, unless otherwise specified)

\begin{tabular}{|c|c|c|c|c|c|}
\hline & 1998/99 & 1999/00 & $2000 / 01$ & $\begin{array}{r}2001 / 02 \\
\text { Prov. }\end{array}$ & $\begin{array}{r}2002 / 03 \\
\text { Prov. }\end{array}$ \\
\hline \multicolumn{6}{|l|}{ Premium gasoline } \\
\hline Import cost, c.i.f. & 25.1 & 49.4 & 37.0 & 29.6 & 37.1 \\
\hline Distribution costs and overheads & 1.9 & 3.6 & 5.6 & 4.1 & 1.6 \\
\hline Taxes & 55.2 & 109.5 & 63.0 & 46.2 & 59.7 \\
\hline Profits (loss -) & -5.7 & -62.5 & -5.7 & 20.1 & 1.6 \\
\hline STC sales price (Mauritian rupees per liter) & 16.6 & 10.5 & $16.62 /$ & $16.62 /$ & $16.43 /$ \\
\hline Retail price (Mauritian rupees per liter) & 14.2 & 12.8 & $19.502 /$ & $19.852 /$ & $20.403 /$ \\
\hline Imports for inland trade (in metric tons) & 93,754 & 90,101 & 86,936 & 88,459 & 87,043 \\
\hline \multicolumn{6}{|l|}{ Diesel } \\
\hline Import cost, c.i.f. & 43.4 & 85.7 & 65.8 & 57.0 & 67.7 \\
\hline Distribution costs and overheads & 3.6 & 5.6 & 9.1 & 6.4 & 1.7 \\
\hline Taxes & 32.4 & 64.5 & 25.9 & 13.3 & 13.4 \\
\hline Profits (loss -) & 20.6 & -55.8 & -0.8 & 23.3 & 17.2 \\
\hline STC sales price (Mauritian rupees per liter) & 5.8 & 5.0 & $9.32 /$ & $9.32 /$ & $9.23 /$ \\
\hline Retail price (Mauritian rupees per liter) & 7.7 & 6.7 & $11.402 /$ & $11.602 /$ & $11.903 /$ \\
\hline Imports for inland trade (in metric tons) & 166,377 & 178,503 & 196,940 & 190,213 & 209,101 \\
\hline \multicolumn{6}{|l|}{ Kerosene } \\
\hline Import cost, c.i.f. & 62.1 & 135.8 & 93.43 & 71.99 & 86.39 \\
\hline Distribution costs and overheads & 0.4 & 5.2 & 12.0 & 7.8 & 2.0 \\
\hline Taxes & 0.0 & 0.0 & 0.0 & 0.0 & 0.0 \\
\hline Profits (loss -) & 37.4 & -41.0 & -5.4 & 20.2 & 11.6 \\
\hline STC sales price (Mauritian rupees per liter) & 4.6 & 3.5 & $7.72 /$ & $7.72 /$ & $7.54 /$ \\
\hline Retail price (Mauritian rupees per liter) & 5.7 & 4.6 & $8.752 /$ & $8.752 /$ & $8.754 /$ \\
\hline Imports for inland trade (in metric tons) & 54,119 & 29,186 & 13,159 & 15,571 & 18,722 \\
\hline \multicolumn{6}{|l|}{ Fuel oil } \\
\hline Import cost, c.i.f. & 55.4 & 103.4 & 118.3 & 56.8 & 71.6 \\
\hline Distribution costs and overheads & 0.5 & 1.1 & 12.2 & 4.3 & 0.3 \\
\hline Taxes & 42.9 & 74.3 & 78.0 & 34.3 & 28.6 \\
\hline Profits (loss -) & 1.2 & -78.7 & -108.4 & 4.6 & -0.4 \\
\hline STC sales price (Mauritian rupees per liter) & 3.7 & 3.7 & 3.7 & $8.25 /$ & $7.06 /$ \\
\hline Imports for inland trade (in metric tons) & 119,042 & 121,185 & 95,244 & 62,616 & 50,888 \\
\hline
\end{tabular}

Source: State Trading Corporation

1/ Fiscal year from July to June. Cost structure relates to that of the State Trading Corporation (STC).

2/ Effective September 30, 2000.

3/ Effective October 1, 2002.

4/ Effective March 18, 2003.

5/ Effective September 1, 2001.

6/ Effective July 1,2002. 
Table 20. Mauritius: Consumer Price Indices by Major Commodity Groups, January 2001-December 2003 1/

\begin{tabular}{|c|c|c|c|c|c|c|c|c|c|c|c|c|c|c|}
\hline & Weights & Jan. & Feb. & Mar. & Apr. & May & June & July & Aug. & Sep. & Oct. & Nov. & Dec. & $\begin{array}{r}\text { Year } \\
\text { (Avg.) }\end{array}$ \\
\hline & \multicolumn{14}{|c|}{ (July 1996-June 1997=100) } \\
\hline \multicolumn{15}{|l|}{2001} \\
\hline Food and nonalcoholic beverages & 36.4 & 120.9 & 121.3 & 120.8 & 121.2 & 121.6 & 123.4 & 124.0 & 124.4 & 124.6 & 125.2 & 126.3 & 127.3 & 123.4 \\
\hline Alcoholic beverages and tobacco & 8.7 & 160.3 & 161.3 & 161.7 & 161.7 & 161.9 & 166.6 & 173.0 & 173.4 & 173.6 & 174.0 & 174.0 & 176.0 & 168.1 \\
\hline Clothing and footwear & 7.9 & 115.6 & 115.7 & 115.7 & 115.7 & 115.7 & 115.8 & 116.8 & 116.8 & 116.8 & 116.9 & 117.1 & 117.4 & 116.3 \\
\hline Fuel and light & 4.4 & 121.9 & 121.9 & 121.9 & 121.9 & 121.9 & 121.9 & 121.9 & 121.9 & 121.9 & 121.9 & 123.8 & 125.5 & 122.4 \\
\hline Housing and household operations & 13.2 & 119.3 & 120.8 & 121.1 & 121.1 & 121.3 & 121.5 & 123.0 & 123.1 & 123.2 & 123.6 & 123.8 & 124.1 & 122.2 \\
\hline Medical care and health expenses & 3.8 & 124.6 & 124.7 & 125.0 & 125.4 & 126.2 & 127.0 & 127.4 & 127.6 & 127.9 & 129.4 & 129.6 & 130.2 & 127.1 \\
\hline Transport and communications & 14.2 & 130.7 & 130.6 & 130.1 & 130.5 & 130.6 & 130.1 & 135.2 & 135.5 & 135.6 & 136.1 & 136.2 & 136.3 & 133.1 \\
\hline \multicolumn{15}{|l|}{ Recreation, entertainment, education, } \\
\hline and cultural services & 6.0 & 129.3 & 131.6 & 132.0 & 132.1 & 132.5 & 132.5 & 132.6 & 132.6 & 132.8 & 132.8 & 132.8 & 132.8 & 132.2 \\
\hline Miscellaneous goods and services & 5.4 & 123.0 & 123.1 & 122.8 & 122.5 & 122.4 & 122.1 & 123.2 & 123.5 & 124.1 & 124.1 & 124.4 & 124.6 & 123.3 \\
\hline Total & 100.0 & 125.9 & 126.5 & 126.3 & 126.5 & 126.8 & 127.8 & 129.7 & 129.9 & 130.1 & 130.5 & 131.1 & 131.8 & 128.6 \\
\hline Average for fiscal year ended June 30 & & & & & & & 124.9 & & & & & & & \\
\hline \multicolumn{15}{|l|}{2002} \\
\hline Food and nonalcoholic beverages & 36.4 & 129.2 & 131.4 & 133.2 & 133.8 & 134.1 & 133.9 & & & & & & & \\
\hline Alcoholic beverages and tobacco & 8.7 & 176.0 & 176.0 & 176.0 & 176.1 & 176.1 & 176.1 & & & & & & & \\
\hline Clothing and footwear & 7.9 & 117.5 & 117.5 & 117.7 & 117.8 & 117.8 & 117.8 & & & & & & & \\
\hline Fuel and light & 4.4 & 135.8 & 135.8 & 135.8 & 135.8 & 135.8 & 135.8 & & & & & & & \\
\hline Housing and household operations & 13.2 & 126.2 & 126.5 & 126.9 & 127.0 & 127.1 & 127.3 & & & & & & & \\
\hline Medical care and health expenses & 3.8 & 130.4 & 132.1 & 132.3 & 132.7 & 133.4 & 133.6 & & & & & & & \\
\hline Transport and communication & 14.2 & 136.0 & 135.7 & 135.8 & 135.6 & 135.7 & 136.1 & & & & & & & \\
\hline \multicolumn{15}{|l|}{ Recreation, entertainment, education, } \\
\hline and cultural services & 6.0 & 135.4 & 140.2 & 140.3 & 140.3 & 140.3 & 140.3 & & & & & & & \\
\hline Miscellaneous goods and services & 5.4 & 126.8 & 127.2 & 127.4 & 127.7 & 127.9 & 128.1 & & & & & & & \\
\hline \multirow[t]{3}{*}{ Total } & 100.0 & 133.5 & 134.7 & 135.4 & 135.7 & 135.9 & 135.9 & 137.8 & 139.3 & 139.6 & 140.4 & 140.7 & 140.7 & \\
\hline & \multicolumn{14}{|c|}{ (July 2001-June 2002=100) } \\
\hline & Weights & & & & & & & & & & & & & \\
\hline Food and nonalcoholic beverages & 29.9 & & & & & & & 103.2 & 103.2 & 103.8 & 103.8 & 103.6 & 103.2 & \\
\hline Alcoholic beverages and tobacco & 8.6 & & & & & & & 104.5 & 104.1 & 104.6 & 104.8 & 104.7 & 106.2 & \\
\hline Clothing and footwear & 6 & & & & & & & 101.9 & 102.1 & 102.1 & 102.3 & 102.4 & 102.5 & \\
\hline Housing, water, electricity, gas and other fuels & 9.6 & & & & & & & 101.8 & 103.7 & 103.7 & 103.7 & 103.7 & 103.7 & \\
\hline \multicolumn{15}{|l|}{ Furnishings, household equipment } \\
\hline and routine household maintenance & 8 & & & & & & & 103.7 & 103.4 & 104.2 & 104.0 & 104.3 & 103.6 & \\
\hline Health & 2.8 & & & & & & & 103.8 & 105.5 & 105.9 & 106.8 & 107.2 & 107.7 & \\
\hline Transport & 13.9 & & & & & & & 103.4 & 105.8 & 105.9 & 106.3 & 105.5 & 105.4 & \\
\hline Communication & 3.1 & & & & & & & 101.2 & 101.2 & 101.1 & 122.6 & 122.6 & 121.2 & \\
\hline Recreation and culture & 5.3 & & & & & & & 102.5 & 102.5 & 102.5 & 103.6 & 103.0 & 103.6 & \\
\hline Education & 2.4 & & & & & & & 101.7 & 101.7 & 101.7 & 101.7 & 101.7 & 101.7 & \\
\hline Restaurants and hotels & 5 & & & & & & & 102.9 & 103.3 & 103.5 & 103.9 & 105.4 & 105.6 & \\
\hline \multirow[t]{2}{*}{ Miscellaneous goods and services } & 5.4 & & & & & & & 104.2 & 104.4 & 104.70 & 108.1 & 107.9 & 107.8 & \\
\hline & 100 & & & & & & & 103.1 & 103.6 & 104.00 & 105.0 & 104.9 & 104.8 & \\
\hline 2003 & Weights & & & & & & & & & & & & & \\
\hline Food and nonalcoholic beverages & 29.9 & 103.9 & 104.2 & 104.1 & 104.2 & 105.5 & 106.2 & 106.6 & 106.5 & 107.4 & 107.1 & 107.2 & 107.7 & 105.9 \\
\hline Alcoholic beverages and tobacco & 8.6 & 106.6 & 106.5 & 106.4 & 106.9 & 108.0 & 110.0 & 110.8 & 110.6 & 110.6 & 112.2 & 112.2 & 115.7 & 109.7 \\
\hline Clothing and footwear & 6.0 & 102.8 & 103.0 & 102.9 & 101.7 & 103.3 & 103.4 & 103.6 & 103.8 & 103.8 & 103.7 & 103.9 & 103.9 & 103.3 \\
\hline Housing, water, electricity, gas and other fuels & 9.6 & 103.7 & 104.0 & 104.1 & 104.1 & 104.2 & 104.3 & 105.7 & 105.9 & 105.8 & 105.8 & 105.9 & 105.9 & 105.0 \\
\hline \multicolumn{15}{|l|}{ Furnishings, household equipment } \\
\hline and routine household maintenance & 8.0 & 104.9 & 105.0 & 104.6 & 104.9 & 104.8 & 104.9 & 106.3 & 106.0 & 106.3 & 106.1 & 106.4 & 105.8 & 105.5 \\
\hline Health & 2.8 & 107.9 & 108.2 & 108.3 & 108.6 & 108.6 & 109.1 & 110.0 & 109.9 & 110.9 & 112.6 & 113.1 & 113.5 & 110.1 \\
\hline Transport & 13.9 & 106.0 & 106.0 & 105.6 & 106.2 & 106.3 & 106.6 & 107.2 & 105.8 & 105.4 & 106.0 & 106.2 & 106.7 & 106.2 \\
\hline Communication & 3.1 & 122.0 & 122.4 & 123.3 & 122.5 & 122.5 & 121.3 & 121.7 & 121.7 & 128.7 & 133.9 & 133.9 & 133.3 & 125.6 \\
\hline Recreation and culture & 5.3 & 103.9 & 104.1 & 103.9 & 104.3 & 104.5 & 104.5 & 105.1 & 105.1 & 105.2 & 104.8 & 104.5 & 104.7 & 104.6 \\
\hline Education & 2.4 & 107.1 & 107.1 & 107.1 & 107.1 & 107.1 & 107.1 & 107.1 & 108.5 & 108.5 & 108.5 & 108.5 & 108.5 & 107.7 \\
\hline Restaurants and hotels & 5.0 & 106.3 & 106.7 & 106.8 & 106.8 & 108.0 & 107.9 & 108.0 & 108.1 & 108.2 & 108.7 & 108.8 & 109.0 & 107.8 \\
\hline Miscellaneous goods and services & 5.4 & 108.4 & 109.0 & 108.8 & 109.4 & 109.4 & 109.7 & 110.1 & 112.4 & 112.6 & 112.8 & 113.3 & 112.8 & 110.7 \\
\hline Total & 100.0 & 105.5 & 105.7 & 105.6 & 105.8 & 106.5 & 106.9 & 107.5 & 107.4 & 107.9 & 108.3 & 108.4 & 108.9 & 107.0 \\
\hline Average for fiscal year ended June 30 & & & & & & & 105.1 & & & & & & & \\
\hline
\end{tabular}

1/ As from July 2002, a new series of the Consumer Price Index (CPI) has been introduced. A new basket of goods and services is used for the computation of this index following the 2001/02 Household Budget Survey. The commodities in the basket are classfified according to the UN CCEP (Classificaion of Consumption Expenditure according to Purpose). 
Table 21. Mauritius: Summary of Government Finances, 1998/99-2002/03 1/

\begin{tabular}{|c|c|c|c|c|c|}
\hline & 1998/99 & 1999/00 & $2000 / 01$ & $\begin{array}{r}2001 / 02 \\
\text { Rev. Est. }\end{array}$ & $\begin{array}{r}2002 / 03 \\
\text { Prov. }\end{array}$ \\
\hline & \multicolumn{5}{|c|}{ (In millions of Mauritian rupees) } \\
\hline Total revenue and grants & 21,329 & 23,500 & 22,707 & 25,270 & 30,298 \\
\hline Tax revenue & 17,900 & 20,373 & 20,189 & 21,519 & 25,879 \\
\hline Nontax revenue & 3,294 & 2,966 & 2,318 & 3,435 & 4,056 \\
\hline External grants & 135 & 161 & 199 & 317 & 363 \\
\hline Total expenditure and net lending & 24,851 & 27,810 & 29,846 & 33,569 & 39,533 \\
\hline Current expenditure & 21,847 & 23,379 & 26,786 & 27,881 & 31,538 \\
\hline Wages and salaries & 7,457 & 7,763 & 8,181 & 8,854 & 9,366 \\
\hline Other goods and services & 2,180 & 2,354 & 2,735 & 2,927 & 3,168 \\
\hline Interest payments & 3,626 & 3,856 & 5,527 & 4,541 & 6,390 \\
\hline External interest & 501 & 453 & 401 & 207 & 189 \\
\hline Domestic interest & 3,125 & 3,403 & 5,125 & 4,334 & 6,202 \\
\hline Current transfers and subsidies & 8,584 & 9,406 & 10,342 & 11,558 & 12,614 \\
\hline Capital expenditure and net lending $2 /$ & 2,129 & 3,548 & 2,325 & 5,688 & 7,995 \\
\hline Expenditure by the Privatization Fund & 875 & 883 & 735 & 0 & 0 \\
\hline Overall balance after grants & $-3,522$ & $-4,310$ & $-7,139$ & $-8,299$ & $-9,235$ \\
\hline Financing & 3,522 & 4,310 & 7,139 & 8,299 & 9,235 \\
\hline External (net) & $-1,170$ & -510 & $-3,584$ & 1,070 & 87 \\
\hline Disbursements & 464 & 410 & 349 & 1,778 & 923 \\
\hline Amortization & $-1,634$ & -920 & $-3,932$ & -708 & -836 \\
\hline Domestic & 4,009 & 3,815 & 5,652 & 7,229 & 9,299 \\
\hline Banking system (net) & $-1,571$ & 2,579 & -959 & 1,314 & 2,496 \\
\hline Nonbank & 5,580 & 1,236 & 6,611 & 5,915 & 6,803 \\
\hline \multirow[t]{2}{*}{ Sale of equity in state-owned enterprises and residual 3/ } & 684 & 1,006 & 5,071 & 0 & -151 \\
\hline & \multicolumn{5}{|c|}{ (Annual change in percent) } \\
\hline Total revenue and grants & 15.3 & 10.2 & -3.4 & 11.3 & -1.7 \\
\hline \multirow[t]{2}{*}{ Total expenditure and net lending } & 12.3 & 11.9 & 7.3 & 12.5 & -0.7 \\
\hline & \multicolumn{5}{|c|}{ (In percent of GDP) } \\
\hline Total revenue and grants & 20.1 & 20.9 & 18.2 & 18.4 & 20.3 \\
\hline Of which: tax revenue & 16.9 & 18.1 & 16.1 & 15.7 & 17.4 \\
\hline Total expenditure and net lending & 23.4 & 24.7 & 23.9 & 24.5 & 26.5 \\
\hline Current expenditure & 20.6 & 20.8 & 21.4 & 20.3 & 21.2 \\
\hline Capital expenditure and net lending 2/ & 2.0 & 3.1 & 1.9 & 4.1 & 5.4 \\
\hline Overall balance after grants & -3.3 & -3.8 & -5.7 & -6.0 & -6.2 \\
\hline Overall balance, excluding exceptional factors 4/ & -4.6 & -4.3 & -7.1 & -6.6 & -6.2 \\
\hline External financing & -1.1 & -0.5 & -2.9 & 0.8 & 0.1 \\
\hline Domestic financing & 3.8 & 3.4 & 4.5 & 5.3 & 6.2 \\
\hline Of which: banking system & -1.5 & 2.3 & -0.8 & 1.0 & 1.7 \\
\hline Sale of equity in state-owned enterprises and residual 3/ & 0.6 & 0.9 & 4.1 & 0.0 & -0.1 \\
\hline
\end{tabular}

Sources: Ministry of Finance; and Bank of Mauritius.

1/ Budgetary central government, Government Finance Statistics basis; fiscal year from July to June.

2/ From 1996/97 to 1997/98, net lending includes the on-lending of the proceeds from an international floating rate note (FRN) issue of US\$150 million. In 1998/99, it includes the repayment of the FRN on-lending equivalent to 0.8 percent of GDP.

3/ Includes proceeds from the sale of government equity in state-owned enterprises, equivalent to 0.9 percent of GDP in 1996/97, and 5.7 percent of GDP in 2000/01

4/ Exceptional factors include the on-lending of the proceeds from the FRN equivalent to 2.2 percent of GDP in 1996/97, and to 0.1 percent of GDP in 1997/98. They also include the repayment of the FRN on-lending equivalent to 0.8 percent of GDP in 1998/99, and 1.4 percent of GDP in 2000/01, as well as the proceeds from the sale of fixed assets equivalent to 0.5 percent of GDP in 1998/99 and 0.4 percent of GDP in 1999/2000. 
Table 22. Mauritius: Revenue and Grants, Budgetary Central Government, 1998/99-2002/03 1/

(In millions of Mauritian rupees)

\begin{tabular}{|c|c|c|c|c|c|}
\hline & 1998/99 & 1999/00 & $2000 / 01$ & $\begin{array}{c}2001 / 02 \\
\text { Rev. Est. }\end{array}$ & $\begin{array}{r}2002 / 03 \\
\text { Prov. }\end{array}$ \\
\hline Tax revenue & 17,900 & 20,373 & 20,189 & 21,519 & 25,879 \\
\hline Taxes on net income and profits & 2,700 & 2,881 & 3,039 & 3,494 & 4,014 \\
\hline Individuals & 1,363 & 1,540 & 1,518 & 1,619 & 1,859 \\
\hline Corporate & 1,337 & 1,341 & 1,521 & 1,875 & 2,155 \\
\hline Taxes on property & 1,209 & 1,206 & 1,324 & 1,299 & 1,375 \\
\hline Land and real estate & 213 & 218 & 279 & 250 & 306 \\
\hline Financial transactions & 996 & 988 & 1,045 & 1,049 & 1,068 \\
\hline Registration fees & 982 & 960 & 1,017 & 1,028 & 1,056 \\
\hline Incorporation and lodging fees & 10 & 19 & 20 & 12 & 4 \\
\hline Mortgages & 5 & 9 & 8 & 10 & 9 \\
\hline Taxes on domestic goods and services & 8,005 & 9,339 & 9,466 & 10,821 & 13,957 \\
\hline Selective excises & 1,776 & 2,160 & 2,107 & 2,299 & 2,332 \\
\hline Alcoholic beverages & 769 & 946 & 927 & 996 & 1,008 \\
\hline Tobacco & 1,006 & 1,213 & 1,178 & 1,302 & 1,323 \\
\hline Other & 1 & 1 & 1 & 1 & 1 \\
\hline Taxes on services & 1,136 & 1,099 & 957 & 979 & 1,069 \\
\hline Gambling and lottery profits & 765 & 892 & 859 & 891 & 967 \\
\hline Tourism & 371 & 206 & 98 & 87 & 101 \\
\hline Taxes on use of goods & 455 & 476 & 477 & 490 & 744 \\
\hline Business licenses & 141 & 143 & 126 & 112 & 162 \\
\hline Motor vehicles & 314 & 334 & 351 & 378 & 582 \\
\hline Sales tax on goods/value-added tax & 4,639 & 5,604 & 5,925 & 7,053 & 9,812 \\
\hline Taxes on international trade & 5,973 & 6,935 & 6,349 & 5,893 & 6,523 \\
\hline Import duties & 5,973 & 6,935 & 6,349 & 5,893 & 6,523 \\
\hline Customs duties & 5,972 & 6,924 & 6,349 & 5,893 & 6,523 \\
\hline Stamp duties & 1 & 11 & 0 & 0 & 0 \\
\hline Export duties & 0 & 0 & 0 & 0 & 0 \\
\hline Other tax revenue (stamp duty) & 13 & 12 & 11 & 13 & 12 \\
\hline Nontax revenue & 3,294 & 2,966 & 2,318 & 3,435 & 4,056 \\
\hline Property income & 2,246 & 1,862 & 1,660 & 1,774 & 2,861 \\
\hline Bank of Mauritius & 825 & 800 & 800 & 1,200 & 1,500 \\
\hline Interest and royalties & 585 & 448 & 351 & 294 & 840 \\
\hline Dividends & 592 & 543 & 426 & 196 & 457 \\
\hline Operating surpluses & 194 & 5 & 12 & 0 & 0 \\
\hline Rent and other & 50 & 66 & 71 & 85 & 99 \\
\hline Other nontax revenue & 548 & 604 & 658 & 1,052 & 1,172 \\
\hline Fees, charges, and sales & 385 & 409 & 450 & 594 & 613 \\
\hline Fines and forfeits & 46 & 65 & 76 & 97 & 104 \\
\hline Government pension fund & 114 & 120 & 123 & 131 & 135 \\
\hline Miscellaneous & 4 & 10 & 8 & 230 & 320 \\
\hline Total revenue & 21,194 & 23,339 & 22,507 & 24,954 & 29,935 \\
\hline Foreign grants & 135 & 161 & 199 & 317 & 363 \\
\hline Total revenue and grants & 21,329 & 23,500 & 22,707 & 25,270 & 30,298 \\
\hline
\end{tabular}

Source: Ministry of Finance.

1/ Fiscal year from July to June. 
Table 23. Mauritius: Functional Classification of Expenditure and Net Lending, Consolidated Central Government, 1998/99-2002/03 1/

(In millions of Mauritian rupees)

\begin{tabular}{|c|c|c|c|c|c|}
\hline & 1998/99 & 1999/00 & $2000 / 01$ & $\begin{array}{l}\text { 2001/02 } \\
\text { Rev. Est. }\end{array}$ & $\begin{array}{r}2002 / 03 \\
\text { Prov. }\end{array}$ \\
\hline Total expenditure & 25,556 & 27,643 & 31,420 & 32,925 & 38,553 \\
\hline Public administration and security & 4,608 & 4,767 & 5,363 & 5,718 & 6,319 \\
\hline General public services & 2,384 & 2,524 & 2,917 & 2,931 & 3,115 \\
\hline Defense & 216 & 239 & 253 & 270 & 299 \\
\hline Public order and safety & 2,008 & 2,004 & 2,193 & 2,517 & 2,905 \\
\hline Social services & 12,860 & 13,951 & 15,494 & 18,084 & 19,856 \\
\hline Education & 3,866 & 3,987 & 4,357 & 4,755 & 5,578 \\
\hline Health and sanitation & 2,132 & 2,256 & 2,547 & 2,884 & 3,151 \\
\hline Social security and welfare & 5,140 & 5,563 & 6,160 & 6,698 & 6,988 \\
\hline Housing and community amenities $2 /$ & 1,298 & 1,704 & 2,023 & 3,255 & 3,323 \\
\hline Recreational, cultural, and religious & 424 & 441 & 408 & 492 & 817 \\
\hline Economic services & 3,649 & 4,192 & 4,175 & 3,666 & 4,231 \\
\hline Fuel and energy & 23 & 25 & 23 & 44 & 34 \\
\hline Agriculture, forestry, and fishing & 1,389 & 1,260 & 1,329 & 1,276 & 1,275 \\
\hline Mining, manufacturing, and construction & 155 & 174 & 198 & 157 & 155 \\
\hline Transport and communications & 1,051 & 1,102 & 1,855 & 887 & 1,123 \\
\hline Other economic services & 1,031 & 1,631 & 770 & 1,302 & 1,644 \\
\hline Other purposes & 4,439 & 4,733 & 6,388 & 5,456 & 8,147 \\
\hline Public debt interest & 3,626 & 3,856 & 5,527 & 4,541 & 6,390 \\
\hline Transfers to local governments & 813 & 877 & 861 & 914 & 969 \\
\hline Other & 0 & 0 & 0 & 0 & 787 \\
\hline Lending minus repayments $3 /$ & -705 & 167 & $-1,574$ & 645 & 980 \\
\hline Total expenditure and net lending & 24,851 & 27,810 & 29,846 & 33,569 & 39,533 \\
\hline
\end{tabular}

Sources: Ministry of Finance; and Central Statistics Office.

1/ Budgetary central government, Government Finance Statistics basis; fiscal year from July to June.

2/ Includes water supply.

3/ From 1996/97 to 1997/98, net lending includes the on-lending of the proceeds from an international floating rate note (FRN) issue of US\$150 million. In 1998/99, it includes the repayment of the FRN on-lending equivalent to 0.8 percent of GDP. 
Table 24. Mauritius: Transfers and Subsidies by Budgetary Central Government, 1998/99-2002/03 1/

(In millions of Mauritian rupees)

\begin{tabular}{|c|c|c|c|c|c|}
\hline & 1998/99 & $1999 / 00$ & $2000 / 01$ & $\begin{array}{r}\text { 2001/02 } \\
\text { Rev. Est. }\end{array}$ & $\begin{array}{r}2002 / 03 \\
\text { Prov. }\end{array}$ \\
\hline Subsidies and other current transfers & 8,585 & 9,406 & 10,342 & 11,558 & 12,614 \\
\hline Local governments & 741 & 762 & 790 & 851 & 904 \\
\hline Education & 1,887 & 1,966 & 2,143 & 2,264 & 2,469 \\
\hline Secondary schools & 1,004 & 1,047 & 1,116 & 1,202 & 1,313 \\
\hline University of Mauritius & 430 & 194 & 208 & 210 & 230 \\
\hline Education Institute & 0 & 80 & 78 & 91 & 96 \\
\hline Gandhi Institute & 0 & 103 & 110 & 111 & 129 \\
\hline College of the Air & 0 & 47 & 55 & 54 & 58 \\
\hline Block grant & 148 & 137 & 142 & 145 & 162 \\
\hline Examination Syndicate & 69 & 69 & 74 & 78 & 85 \\
\hline Other & 236 & 290 & 361 & 373 & 396 \\
\hline Public service pensions & 1,362 & 1,595 & 1,724 & 1,868 & 1,965 \\
\hline National Pension Fund & 2,932 & 3,177 & 3,507 & 3,777 & 4,178 \\
\hline Rice and wheat flour & 369 & 443 & 339 & 393 & 429 \\
\hline Domestic crops & 99 & 53 & 64 & 0 & 0 \\
\hline Unemployment fund & 0 & 0 & 1 & 0 & 0 \\
\hline Outdoor relief & 41 & 0 & 0 & 0 & 0 \\
\hline Development Works Corporation (DWC) 2/ & 90 & 122 & 115 & 140 & 85 \\
\hline Other current transfers & 1,063 & 1,287 & 1,660 & 2,265 & 2,583 \\
\hline Capital transfers & 1,009 & 1,398 & 1,737 & 1,435 & 1,907 \\
\hline Local governments & 1 & 0 & 0 & 63 & 65 \\
\hline Public financial institutions & 222 & 191 & 225 & 194 & 192 \\
\hline Nonfinancial public enterprises & 777 & 1,199 & 1,501 & 1,130 & 1,291 \\
\hline Aviation, PTT, 3 / and sewerage & 344 & 687 & 851 & 0 & 0 \\
\hline Other & 433 & 512 & 650 & 37 & 55 \\
\hline International organizations & 2 & 2 & 8 & 11 & 37 \\
\hline Other & 7 & 7 & 3 & 0 & 268 \\
\hline Total subsidies and transfers & 9,593 & 10,804 & 12,080 & 12,993 & 14,521 \\
\hline
\end{tabular}

Source: Ministry of Finance.

1/ Fiscal year from July to June.

2/ Includes mainly wages and salaries for government employees transferred to the DWC.

3/ PTT is the postal and telecommunications enterprise. 
Table 25. Mauritius: Income and Expenditure of the National Pension Fund, 1998/99-2002/03 1/

(In millions of Mauritian rupees)

\begin{tabular}{|c|c|c|c|c|c|}
\hline & 1998/99 & $1999 / 00$ & $2000 / 01$ & $\begin{array}{r}\text { 2001/02 } \\
\text { Rev. Est. }\end{array}$ & $\begin{array}{r}2002 / 03 \\
\text { Prov. }\end{array}$ \\
\hline Income & 5,457 & 6,117 & 6,887 & 6,140 & 8,258 \\
\hline Government grant & 2,941 & 3,267 & 3,606 & 3,741 & 4,182 \\
\hline Contributions from employers and employees & 893 & 984 & 1,004 & 986 & 1,122 \\
\hline Investment income & 1,405 & 1,718 & 2,071 & 1,253 & 2,800 \\
\hline Other income & 218 & 148 & 206 & 160 & 154 \\
\hline Expenditure & 3,271 & 3,662 & 4,107 & 4,236 & 4,821 \\
\hline Noncontributory (basic) pensions & 2,929 & 3,262 & 3,598 & 3,728 & 4,132 \\
\hline Food aid allowance & 11 & 6 & 16 & 12 & 10 \\
\hline Contributory and industrial injury pensions & 242 & 280 & 342 & 382 & 558 \\
\hline Administration and other costs & 89 & 114 & 151 & 114 & 121 \\
\hline Excess of income over expenditure & 2,186 & 2,455 & 2,780 & 1,904 & 3,437 \\
\hline Balance in fund at end of year $2 /$ & 16,444 & 18,899 & 21,679 & 23,583 & 28,473 \\
\hline
\end{tabular}

Source: National Pension Fund.

1/ Fiscal year from July to June.

2/ Change in balance at end of year may differ from excess of income over expenditure owing to valuation adjustments. 
Table 26. Mauritius: State Trading Corporation -

Ration Rice and Flour Transactions, 1998/99-2002/03 1/

\begin{tabular}{|c|c|c|c|c|c|}
\hline & 1998/99 & $1999 / 00$ & $2000 / 01$ & $\begin{array}{l}\text { 2001/02 } \\
\text { Rev. Est. }\end{array}$ & $\begin{array}{r}2002 / 03 \\
\text { Prov. }\end{array}$ \\
\hline & \multicolumn{5}{|c|}{ (In millions of Mauritian rupees) } \\
\hline Sales revenue & 528 & 544 & 534 & 516 & 512 \\
\hline Ration rice & 187 & 195 & 187 & 166 & 151 \\
\hline Flour & 341 & 350 & 347 & 350 & 361 \\
\hline Total cost & 875 & 872 & 875 & 797 & 916 \\
\hline Ration rice & 340 & 369 & 349 & 266 & 260 \\
\hline Flour & 535 & 504 & 527 & 531 & 656 \\
\hline Purchasing cost & 828 & 788 & 804 & 720 & 816 \\
\hline Ration rice & 310 & 320 & 305 & 221 & 198 \\
\hline Flour & 519 & 467 & 498 & 499 & 618 \\
\hline Other charges & 46 & 85 & 72 & 77 & 100 \\
\hline Ration rice & 30 & 48 & 43 & 45 & 62 \\
\hline Flour & 17 & 37 & 28 & 32 & 38 \\
\hline Balance $($ deficit $=-)$ & -347 & -328 & -341 & -281 & -404 \\
\hline Ration rice & -152 & -174 & -162 & -100 & -109 \\
\hline Flour & -194 & -154 & -180 & -181 & -295 \\
\hline Financing & 347 & 328 & 341 & 281 & 404 \\
\hline Budgetary transfers & 347 & 328 & 321 & 0 & 404 \\
\hline Other financing 2 / & 0 & 0 & 21 & 281 & 0 \\
\hline Memorandum items: & & & ric tons) & & \\
\hline \multicolumn{6}{|l|}{ Sales volume } \\
\hline Ration rice & 40,854 & 43,778 & 42,242 & 37,445 & 34,000 \\
\hline Flour & 83,029 & 85,279 & 84,670 & 85,395 & 88,000 \\
\hline \multicolumn{6}{|c|}{ (In Mauritian rupees per metric ton) } \\
\hline Rice unit values & & & & & \\
\hline Fixed price, initial & 4,420 & 4,420 & 4,420 & 4,420 & 4,420 \\
\hline Fixed price, final & 4,420 & 4,420 & 4,420 & 4,420 & 4,420 \\
\hline Revenue & 4,582 & 4,449 & 4,427 & 4,433 & 4,441 \\
\hline Cost & 8,314 & 8,420 & 8,250 & 7,104 & 7,647 \\
\hline Subsidy & 3,732 & 3,970 & 3,823 & 2,671 & 3,206 \\
\hline \multicolumn{6}{|l|}{ Flour unit values } \\
\hline Fixed price, initial & 4,100 & 4,100 & 4,100 & 4,100 & 4,100 \\
\hline Fixed price, final & 4,100 & 4,100 & 4,100 & 4,100 & 4,100 \\
\hline Revenue & 4,103 & 4,101 & 4,098 & 4,099 & 4,102 \\
\hline Cost & 6,446 & 5,909 & 6,219 & 6,218 & 7,455 \\
\hline Subsidy & 2,342 & 1,808 & 2,121 & 2,120 & 3,352 \\
\hline \multicolumn{6}{|c|}{ (Annual change in percent) } \\
\hline \multicolumn{6}{|l|}{ Sales volume } \\
\hline Ration rice & -4.1 & 7.2 & -3.5 & -11.4 & -9.2 \\
\hline Flour & 4.2 & 2.7 & -0.7 & 0.9 & 3.1 \\
\hline \multicolumn{6}{|c|}{ (In percent) } \\
\hline Revenue/total cost ratio & 60.3 & 62.4 & 61.0 & 64.7 & 55.9 \\
\hline Ration rice revenue/cost & 55.1 & 52.8 & 53.7 & 62.4 & 58.1 \\
\hline Flour revenue/cost & 63.7 & 69.4 & 65.9 & 65.9 & 55.0 \\
\hline
\end{tabular}

Source: State Trading Corporation.

1/ Fiscal year from July to June. Ration rice is a variety of rice.

2/ Residual; reflects extrabudgetary financing (overdrafts and acceptances, net of deposits) and timing discrepancies. 
Table 27. Mauritius: Financing of Central Government Deficit, 1998/99-2002/03 1/

(In millions of Mauritian rupees)

\begin{tabular}{|c|c|c|c|c|c|}
\hline & 1998/99 & $1999 / 00$ & $2000 / 01$ & $\begin{array}{c}\text { 2001/02 } \\
\text { Rev. Est. }\end{array}$ & $\begin{array}{c}2002 / 03 \\
\text { Prov. }\end{array}$ \\
\hline External financing (net) & $-1,170$ & -509 & $-3,584$ & 1,031 & 88 \\
\hline Eurocurrency (net) & 0 & 0 & 0 & 0 & 0 \\
\hline Other external (net) & $-1,170$ & -509 & $-3,584$ & $-1,030$ & 87 \\
\hline Disbursements by purpose & 464 & 411 & 348 & 1,739 & 924 \\
\hline Nonproject loans & 0 & 0 & 0 & 1,149 & 163 \\
\hline Project loans & 464 & 411 & 348 & 590 & 761 \\
\hline Mixed project and suppliers' credits & 0 & 5 & 34 & 18 & 134 \\
\hline Electric power & 3 & 13 & 46 & 161 & 161 \\
\hline Water and irrigation & 80 & 74 & 182 & 148 & 120 \\
\hline Other agriculture & 18 & 0 & 0 & 0 & 0 \\
\hline Roads, highways, and bridges & 0 & 0 & 0 & 0 & 0 \\
\hline Telecommunications & 0 & 0 & 0 & 0 & 0 \\
\hline Housing projects & 69 & 0 & 0 & 0 & 0 \\
\hline Urban development & 0 & 0 & 0 & 0 & 0 \\
\hline Education & 94 & 0 & 0 & 21 & 0 \\
\hline Environment & 95 & 295 & 67 & 194 & 260 \\
\hline Other projects & 105 & 25 & 20 & 48 & 86 \\
\hline Disbursements by source & 464 & 411 & 368 & 1,738 & 923 \\
\hline Bilateral lenders & 180 & 61 & 184 & 278 & 295 \\
\hline Multilateral agencies & 284 & 350 & 184 & 1,500 & 465 \\
\hline Miscellaneous & 0 & 0 & 0 & -40 & 163 \\
\hline Repayments (-) & $-1,634$ & -920 & $-3,932$ & -708 & -836 \\
\hline Eurocurrency & 0 & 0 & 0 & 0 & 0 \\
\hline Other loans 2/ & $-1,634$ & -920 & $-3,932$ & -708 & -836 \\
\hline Domestic financing (net) & 4,009 & 3,814 & 5,653 & 6,346 & 9,299 \\
\hline Banking system & $-1,571$ & 2,579 & -958 & 1,402 & 2,496 \\
\hline Bank of Mauritius & 1,893 & $-1,496$ & -651 & $-5,545$ & $-7,787$ \\
\hline Commercial banks & $-3,464$ & 4,075 & -307 & 6,947 & 10,283 \\
\hline Nonbank & 5,580 & 1,236 & 6,611 & 4,944 & 6,803 \\
\hline Short-term instruments & 6,145 & 1,873 & 7,097 & 4,849 & 5,747 \\
\hline Long-term instruments & -565 & -638 & -486 & 95 & 1,056 \\
\hline Residual 3/ & 684 & 1,006 & 5,071 & 932 & -151 \\
\hline Total financing & 3,522 & 4,310 & 7,139 & 8,299 & 9,235 \\
\hline
\end{tabular}

Sources: Ministry of Finance; Bank of Mauritius; and IMF staff estimates.

1/ Fiscal year from July to June.

2/ Includes the partial repayment of US\$33 million of the floating rate note in 1998/99.

3/ Reflects differences of coverage and valuation, as well as timing; includes proceeds from the sale of government equity in state-owned enterprises equivalent to 5.7 percent of GDP in 2000/01. 
Table 28. Mauritius: Government Domestic Nonbank Debt Outstanding by Holder, 1998/99-2002/03 1/

(In millions of Mauritian rupees; end of period)

\begin{tabular}{|c|c|c|c|c|c|}
\hline & 1998/99 & 1999/00 & $2000 / 01$ & $\begin{array}{r}2001 / 02 \\
\text { Rev. Est. }\end{array}$ & $\begin{array}{r}2002 / 03 \\
\text { Prov. }\end{array}$ \\
\hline National Pension Fund & 8,385 & 8,535 & 12,820 & 14,707 & 18,355 \\
\hline Short term & 4,166 & 4,418 & 6,937 & 8,885 & 12,377 \\
\hline Long term & 4,219 & 4,117 & 5,883 & 5,822 & 5,978 \\
\hline Post Office Savings Bank & 173 & 160 & 236 & 403 & 1,253 \\
\hline Short term & 36 & 24 & 112 & 279 & 1,152 \\
\hline Long term & 137 & 137 & 124 & 124 & 101 \\
\hline State Insurance Corporation & 1355 & 2081 & 3620 & 4620 & 6061 \\
\hline Short term & 629 & 1,391 & 2,272 & 3,358 & 4,693 \\
\hline Long term & 726 & 690 & 1,348 & 1,262 & 1,368 \\
\hline Insurance companies & 940 & 679 & 1,489 & 2,143 & 3,162 \\
\hline Short term & 695 & 494 & 1,298 & 1,990 & 2,689 \\
\hline Long term & 245 & 185 & 191 & 153 & 473 \\
\hline Sugar Insurance Fund Board (SIFB) 2/ & 400 & 385 & 874 & 1,297 & 1,117 \\
\hline Short term & 400 & 385 & 874 & 1,297 & 1,117 \\
\hline Long term & 0 & 0 & 0 & 0 & 0 \\
\hline National Savings Fund (NSF) 3/ & 969 & 989 & 2,092 & 2,486 & 3,244 \\
\hline Short term & 842 & 862 & 1,738 & 2,132 & 2,790 \\
\hline Long term & 127 & 127 & 354 & 354 & 454 \\
\hline Employees' Welfare Fund (EWF) 3/ & 379 & 372 & 516 & 495 & 579 \\
\hline Short term & 356 & 349 & 493 & 472 & 579 \\
\hline Long term & 23 & 23 & 23 & 23 & 0 \\
\hline Independence and Republic bonds 4/ & 2,375 & 2,079 & 0 & 0 & 0 \\
\hline Short term & 0 & 0 & 0 & 0 & 0 \\
\hline Long term & 2,375 & 2,079 & 0 & 0 & 0 \\
\hline Consolidated Sinking Fund (CSF) 5/ & 2,018 & 2,074 & 323 & 558 & 964 \\
\hline Short term & 500 & 700 & 0 & 0 & 1 \\
\hline Long term & 1,518 & 1,375 & 323 & 558 & 963 \\
\hline Others & 4,294 & 4,901 & 6,850 & 7,053 & 5,833 \\
\hline Short term & 4,246 & 4,853 & 6,802 & 6,961 & 5,725 \\
\hline Long term & 48 & 48 & 48 & 92 & 108 \\
\hline Total & 21,287 & 22,523 & 29,134 & 34,036 & 41,005 \\
\hline Short term & 11,870 & 13,743 & 20,840 & 25,648 & 31,560 \\
\hline Long term & 9,417 & 8,780 & 8,294 & 8,388 & 9,445 \\
\hline \multicolumn{6}{|l|}{ Memorandum items: } \\
\hline Changes during year (total) & 5,580 & 1,236 & 6,611 & 4,902 & 6,967 \\
\hline Short term & 6,145 & 1,873 & 7,097 & 4,808 & 5,911 \\
\hline Long term & -565 & -638 & -486 & 94 & 1,056 \\
\hline
\end{tabular}

Sources: Ministry of Finance; and IMF staff estimates.

1/ Includes tax treasury bills and tax reserve certificates (short term) and government stocks, treasury certificates, and anonymous bearer bonds (long term). Fiscal year from July to June

2/ The SIFB collects premiums from planters and insures sugar crops against natural disasters, such as cyclones and drought.

3/ The NSF and the EWF make deductions from salaries and accumulate funds to contribute to government employees.

4/ Only individuals and nonbank institutions, including the African Development Bank and petroleum companies, subscribe to the Independence and Republic bonds.

5/ Fund for payment of government debt. 
Table 29. Mauritius: External Debt of Central Government - Disbursements, 1998/99-2002/03 1/

(In millions of Mauritian rupees)

\begin{tabular}{|c|c|c|c|c|c|}
\hline & 1998/99 & 1999/00 & $2000 / 01$ & $2001 / 02$ & $2002 / 03$ \\
\hline All bilateral lenders & 179.7 & 60.6 & 184.3 & 278.0 & 295.4 \\
\hline Governments & 176.9 & 34.5 & 46.3 & 40.5 & 210.4 \\
\hline People's Republic of China & 2.4 & 0.0 & 0.0 & 0.0 & 0.0 \\
\hline Flacq Hospital & 0.0 & 0.0 & 0.0 & 0.0 & 0.0 \\
\hline Housing & 2.4 & 0.0 & 0.0 & 0.0 & 0.0 \\
\hline Recreation center & 0.0 & 0.0 & 0.0 & 0.0 & 0.0 \\
\hline France & 107.0 & 18.0 & 3.4 & 37.8 & 57.0 \\
\hline Small-scale irrigation project & 0.0 & 0.0 & 0.0 & 0.0 & 0.0 \\
\hline Goodlands district water supply & 49.8 & 0.0 & 0.0 & 0.0 & 0.0 \\
\hline Hotel catering school & 0.0 & 0.0 & 0.0 & 0.0 & 0.0 \\
\hline Lycée Polytechnique, Rose Hill & 30.0 & 0.0 & 0.0 & 20.9 & 0.0 \\
\hline Northern Plain irrigation project & 22.2 & 15.5 & 0.8 & 4.2 & 5.3 \\
\hline Grand Baei sewerage project & 5.0 & 2.5 & 2.6 & 12.7 & 51.7 \\
\hline India (lines of credit for development projects and supplies) & 0.0 & 5.1 & 32.1 & 0.0 & 145.9 \\
\hline Japan & 67.5 & 11.4 & 10.8 & 2.7 & 0.0 \\
\hline Telecommunications & 0.0 & 0.0 & 0.0 & 0.0 & 0.0 \\
\hline La Butte drainage and soil consolidation project & 67.5 & 11.4 & 10.8 & 2.7 & 0.0 \\
\hline Other bilateral agencies & 2.8 & 26.1 & 138.0 & 237.5 & 85.0 \\
\hline
\end{tabular}


Table 29. Mauritius: External Debt of Central Government - Disbursements, 1998/99-2002/03 1/ (Concluded)

(In millions of Mauritian rupees)

\begin{tabular}{|c|c|c|c|c|c|}
\hline & 1998/99 & $1999 / 00$ & $2000 / 01$ & $2001 / 02$ & $2002 / 03$ \\
\hline Multilateral agencies & 284.2 & 349.9 & 161.8 & $1,482.3$ & 437.9 \\
\hline Arab Bank for Economic Development in Africa & 66.8 & 177.9 & 89.1 & 106.9 & 235.8 \\
\hline Industrial credit & 0.0 & 0.0 & 0.0 & 39.9 & 45.6 \\
\hline Housing rehabilitation & 66.8 & 133.4 & 0.0 & 0.0 & 0.0 \\
\hline Water works & 0.0 & 44.5 & 23.7 & 0.0 & 1.5 \\
\hline Midlands dam & 0.0 & 0.0 & 65.4 & 67.0 & 57.0 \\
\hline Upgraing of Victoria Hospital & 0.0 & 0.0 & 0.0 & 0.0 & 0.0 \\
\hline $132 \mathrm{KV}$ Transmission Line & 0.0 & 0.0 & 0.0 & 0.0 & 131.7 \\
\hline African Development Bank/Fund & 0.0 & 0.0 & 0.0 & 0.0 & 0.0 \\
\hline Bridge project & 0.0 & 0.0 & 0.0 & 0.0 & 0.0 \\
\hline Rose Belle rehabilitation & 0.0 & 0.0 & 0.0 & 0.0 & 0.0 \\
\hline Third highway project & 0.0 & 0.0 & 0.0 & 0.0 & 0.0 \\
\hline Education project & 0.0 & 0.0 & 0.0 & 0.0 & 0.0 \\
\hline Mauritius and Rodrigues sewerage & 0.0 & 0.0 & 0.0 & 0.0 & 0.0 \\
\hline Support to the National Health Plan & 0.0 & 0.0 & 0.0 & 0.0 & 0.0 \\
\hline European Development Fund & 8.7 & 118.2 & 0.0 & 124.5 & 196.8 \\
\hline Prime Minister's rock removal scheme & 0.0 & 0.0 & 0.0 & 0.0 & 0.0 \\
\hline Agricultural and industrial credits & 0.0 & 0.0 & 0.0 & 0.0 & 0.0 \\
\hline Water projects & 8.3 & 0.0 & 0.0 & 0.0 & 0.0 \\
\hline Regional meteorological project & 0.4 & 0.5 & 0.0 & 0.0 & 0.0 \\
\hline Baei du Tombeau sewerage project & 0.0 & 117.7 & 0.0 & 124.5 & 196.8 \\
\hline Plaines Wilhems sewerage project & 0.0 & 0.0 & 0.0 & 0.0 & 0.0 \\
\hline International Bank for Reconstruction and Development & 202.7 & 53.8 & 72.7 & $1,250.9$ & 5.3 \\
\hline Environmental program & 5.3 & 0.0 & 0.0 & 0.0 & 0.0 \\
\hline Debt and liquidity management improvement project & 0.0 & 0.0 & 0.3 & 0.5 & 0.6 \\
\hline Agricultural management services & 18.0 & 0.0 & 0.0 & 0.0 & 0.0 \\
\hline Sugar (bagasse) energy development project & 0.0 & 0.0 & 0.0 & 0.0 & 0.0 \\
\hline Third education project & 46.0 & 0.0 & 0.0 & 0.0 & 0.0 \\
\hline Vocational training & 1.4 & 0.0 & 0.0 & 0.0 & 0.0 \\
\hline Technology development project & 23.3 & 9.8 & 0.0 & 0.0 & 0.0 \\
\hline Higher- and technical education project & 16.5 & 0.0 & 0.0 & 0.0 & 0.0 \\
\hline Freeport project & 80.8 & 14.4 & 19.3 & 7.3 & 0 \\
\hline Sewerage and sanitation & 11.4 & 29.6 & 53.1 & 54.1 & 4.1 \\
\hline Public Expenditure Reform Plan & 0.0 & 0.0 & 0.0 & $1,189.0$ & 0.0 \\
\hline Financial Sector Supervisory Authority & 0.0 & 0.0 & 0.0 & 0.0 & 0.6 \\
\hline Nordic Investment Bank/Development Fund & 6.0 & 0.0 & 0.0 & 0.0 & 0.0 \\
\hline Environmental program & 6.0 & 0.0 & 0.0 & 0.0 & 0.0 \\
\hline Fort George power station & 0.0 & 0.0 & 0.0 & 0.0 & 0.0 \\
\hline Miscellaneous sources (international floating rate note) & 0.0 & 0.0 & 2.2 & 17.5 & 26.7 \\
\hline Total disbursements & 463.9 & 410.5 & 348.3 & $1,777.8$ & 760.0 \\
\hline
\end{tabular}

Source: Ministry of Finance.

1/ Fiscal year from July to June. 
Table 30. Mauritius: Consolidated Monetary Survey, June 1999-December 2003

\begin{tabular}{|c|c|c|c|c|c|c|c|c|c|}
\hline & \multirow{2}{*}{$\frac{1999}{\text { June }}$} & \multicolumn{2}{|c|}{2000} & \multicolumn{2}{|c|}{2001} & \multicolumn{2}{|c|}{2002} & \multicolumn{2}{|c|}{2003} \\
\hline & & June & Dec. & June & Dec. & June & Dec. & June & Dec. \\
\hline & \multicolumn{9}{|c|}{ (In millions of Mauritian rupees) } \\
\hline Net foreign assets & 22,556 & 25,204 & 33,535 & 31,748 & 35,754 & 40,531 & 44,027 & 48,301 & 48,874 \\
\hline Monetary authorities & 15,784 & 17,950 & 25,347 & 23,077 & 25,763 & 30,469 & 36,178 & 40,317 & 41,626 \\
\hline Commercial banks & 6,772 & 7,254 & 8,188 & 8,671 & 9,992 & 10,062 & 7,850 & 7,984 & 7,248 \\
\hline Domestic credit & 77,541 & 88,128 & 85,972 & 92,821 & 98,689 & 100,323 & 105,634 & 107,517 & 117,315 \\
\hline Claims on government (net) & 15,924 & 18,503 & 13,586 & 17,544 & 19,515 & 18,858 & 20,764 & 21,312 & 26,972 \\
\hline Monetary authorities & 4,476 & 2,980 & $-1,225$ & 2,329 & 1,453 & $-3,227$ & $-7,650$ & $-11,285$ & $-5,182$ \\
\hline Commercial banks & 11,448 & 15,522 & 14,810 & 15,215 & 18,062 & 22,085 & 28,414 & 32,596 & 32,154 \\
\hline Claims on private sector $1 /$ & 61,618 & 69,626 & 72,387 & 75,277 & 79,175 & 81,465 & 84,871 & 86,206 & 90,343 \\
\hline Broad money (M2) & 80,172 & 88,910 & 94,871 & 97,720 & 105,241 & 110,440 & 118,357 & 123,365 & 131,223 \\
\hline Money (M1) & 10,905 & 11,065 & 13,297 & 12,711 & 15,452 & 15,131 & 18,157 & 17,437 & 20,401 \\
\hline Quasi money & 69,267 & 77,846 & 81,574 & 85,009 & 89,789 & 95,308 & 100,200 & 105,928 & 110,822 \\
\hline Money market instruments & 0 & 0 & 0 & 0 & 0 & 0 & 0 & 0 & 2,947 \\
\hline \multirow[t]{2}{*}{ Other items (net) } & 19,925 & 24,421 & 24,636 & 26,849 & 29,202 & 30,414 & 31,305 & 32,453 & 32,019 \\
\hline & \multicolumn{9}{|c|}{ (Annual change in percent) } \\
\hline Domestic credit & 13.6 & 13.7 & 4.8 & 5.3 & 14.8 & 8.1 & 7.0 & 7.2 & 11.1 \\
\hline Claims on government (net) & -9.0 & 16.2 & -23.3 & -5.2 & 43.6 & 7.5 & 6.4 & 13.0 & 29.9 \\
\hline Claims on private sector $1 /$ & 21.3 & 13.0 & 12.6 & 8.1 & 9.4 & 8.2 & 7.2 & 5.8 & 6.4 \\
\hline Broad money (M2) & 13.2 & 10.9 & 9.2 & 9.9 & 10.9 & 13.0 & 12.5 & 11.7 & 10.9 \\
\hline Money (M1) & 7.4 & 1.5 & 10.8 & 14.9 & 16.2 & 19.0 & 17.5 & 15.2 & 12.4 \\
\hline \multirow[t]{2}{*}{ Quasi money } & 14.1 & 12.4 & 9.0 & 9.2 & 10.1 & 12.1 & 11.6 & 11.1 & 10.6 \\
\hline & \multicolumn{9}{|c|}{ (Annual change in percent of beginning-of-period broad money) } \\
\hline Net foreign assets & 1.7 & 3.3 & 8.6 & 7.4 & 2.3 & 9.0 & 7.9 & 7.3 & 4.6 \\
\hline Domestic credit & 13.1 & 13.2 & 4.6 & 5.3 & 13.4 & 7.7 & 6.6 & 4.7 & 11.4 \\
\hline Claims on government (net) & -2.2 & 3.2 & -4.8 & -1.1 & 6.2 & 1.3 & 1.2 & 1.8 & 6.2 \\
\hline Claims on private sector $1 /$ & 15.3 & 10.0 & 9.3 & 6.4 & 7.2 & 6.3 & 5.4 & 2.9 & 5.3 \\
\hline Broad money (M2) & 13.2 & 10.9 & 9.2 & 9.9 & 10.9 & 13.0 & 12.5 & 11.7 & 12.2 \\
\hline Velocity (GDP/M2) & 1.3 & 1.3 & 1.3 & 1.3 & 1.3 & 1.2 & 1.2 & 1.2 & 1.2 \\
\hline
\end{tabular}

Sources: Bank of Mauritius; and IMF staff estimates.

1/ Including claims on public enterprises. 


\section{$-111-$}

Table 31. Mauritius: Summary Accounts of the Bank of Mauritius, June 1999-December 2003

(In millions of Mauritian rupees; end of period)

\begin{tabular}{|c|c|c|c|c|c|c|c|c|c|}
\hline & \multirow{2}{*}{$\frac{1999}{\text { June }}$} & \multicolumn{2}{|c|}{2000} & \multicolumn{2}{|c|}{2001} & \multicolumn{2}{|c|}{2002} & \multicolumn{2}{|c|}{2003} \\
\hline & & June & Dec. & June & Dec. & June & Dec. & June & Dec. \\
\hline Net foreign assets & 15,296 & 17,445 & 24,821 & 22,550 & 25,210 & 29,892 & 35,603 & 39,472 & 40,778 \\
\hline Foreign assets & 15,314 & 17,455 & 24,840 & 22,561 & 25,220 & 29,917 & 35,621 & 39,583 & 40,850 \\
\hline Foreign liabilities & -19 & -11 & -19 & -11 & -10 & -25 & -18 & -111 & -72 \\
\hline Claims on government (net) & 4,576 & 3,079 & $-1,128$ & 2,427 & 1,548 & $-3,135$ & $-7,557$ & $-10,931$ & $-4,801$ \\
\hline Treasury bills & 1,320 & 1,852 & 1,441 & 1,350 & 994 & 1,172 & 1,225 & 863 & 761 \\
\hline Government securities & 3 & 47 & 46 & 984 & 1,178 & 770 & 479 & 42 & 39 \\
\hline Advances & 3,162 & 1,089 & 671 & 0 & 0 & 0 & 0 & 0 & 0 \\
\hline Other $1 /$ & 134 & 134 & 134 & 134 & 134 & 134 & 134 & 134 & 134 \\
\hline Government deposits & -42 & -43 & $-3,421$ & -42 & -758 & $\begin{array}{r}-5,211 \\
0\end{array}$ & $\begin{array}{r}-9,394 \\
0\end{array}$ & $\begin{array}{r}-11,970 \\
0\end{array}$ & $\begin{array}{r}-5,734 \\
0\end{array}$ \\
\hline Claims on commercial banks & 250 & 623 & 250 & 253 & 660 & 1,875 & 2,171 & 2,173 & 2,157 \\
\hline Reserve money & 10,344 & 9,765 & 11,764 & 11,342 & 12,990 & 12,920 & 14,921 & 14,774 & 21,909 \\
\hline Currency outside banks & 4,876 & 5,172 & 6,648 & 5,735 & 7,329 & 6,467 & 8,286 & 7,488 & 9,347 \\
\hline Currency with banks & 2,000 & 1,557 & 2,506 & 1,727 & 3,063 & 2,067 & 3,182 & 2,100 & 3,715 \\
\hline Bankers' deposits & 3,448 & 3,024 & 2,524 & 3,790 & 2,450 & 4,240 & 3,342 & 4,992 & 3,139 \\
\hline Of which : non-interest-bearing deposits & 0 & 0 & 0 & 0 & 0 & 0 & 0 & 0 & 0 \\
\hline Banks' holdings of Bank of Mauritius bills & 0 & 0 & 0 & 0 & 0 & 0 & 0 & 0 & 5,595 \\
\hline Private sector demand deposits & 21 & 12 & 86 & 90 & 148 & 147 & 112 & 194 & 114 \\
\hline Money market instruments & 0 & 0 & 0 & 0 & 0 & 0 & 0 & 0 & 2,947 \\
\hline Other items (net) & 9,777 & 11,382 & 12,180 & 13,888 & 14,428 & 15,711 & 15,296 & 15,940 & 13,278 \\
\hline \multicolumn{10}{|l|}{ Memorandum items: } \\
\hline \multicolumn{10}{|l|}{ Monetary authorities } \\
\hline Reserve position with the Fund & 488 & 505 & 526 & 527 & 553 & 577 & 575 & 845 & 848 \\
\hline Claims on government (net) 2/ & 4,476 & 2,980 & $-1,225$ & 2,329 & 1,453 & $-3,227$ & $-7,650$ & $-11,285$ & $-5,182$ \\
\hline
\end{tabular}

Source: Bank of Mauritius.

1/ Use of SDRs (as shown in the accounts of the Bank of Mauritius) and Trust Fund borrowing.

2/ Including transactions with the Fund (based on Fund records). 
Table 32. Mauritius: Summary Accounts of Commercial Banks, June 1999-December 2003

(In millions of Mauritian rupees; end of period)

\begin{tabular}{|c|c|c|c|c|c|c|c|c|c|}
\hline & \multirow{2}{*}{$\frac{1999}{\text { June }}$} & \multicolumn{2}{|c|}{2000} & \multicolumn{2}{|c|}{2001} & \multicolumn{2}{|c|}{2002} & \multicolumn{2}{|c|}{2003} \\
\hline & & June & $\overline{\text { Dec. }}$ & June & Dec. & June & $\overline{\text { Dec. }}$ & June & Dec. \\
\hline Net foreign assets & 6,772 & 7,254 & 8,188 & 8,671 & 9,992 & 10,062 & 7,850 & 7,984 & 7,248 \\
\hline Reserves & 5,448 & 4,582 & 5,030 & 5,516 & 5,513 & 6,307 & 6,523 & 7,092 & 12,449 \\
\hline Of which: holdings of Bank of Mauritius bills & 0 & 0 & 0 & 0 & 0 & 0 & 0 & 0 & 0 \\
\hline Claims on government (net) & 11,448 & 15,522 & 14,810 & 15,215 & 18,062 & 22,085 & 28,414 & 32,596 & 32,154 \\
\hline Government securities & 3,883 & 3,422 & 3,034 & 2,503 & 2,037 & 1,946 & 2,183 & 1,965 & 2,361 \\
\hline Treasury bills & 7,959 & 12,706 & 11,967 & 13,063 & 16,121 & 20,566 & 26,465 & 31,206 & 30,000 \\
\hline Loans and advances & 0 & 0 & 0 & 0 & 0 & 0 & 0 & 0 & 0 \\
\hline State Trading Corporation rice and flour credit & 83 & 1 & 0 & 98 & 129 & 0 & 0 & 0 & 0 \\
\hline Government deposits & -477 & -606 & -191 & -449 & -225 & -426 & -234 & -575 & -208 \\
\hline Claims on private sector & 60,106 & 67,272 & 70,570 & 74,016 & 77,892 & 79,976 & 83,977 & 85,080 & 88,424 \\
\hline Sugar industry & 3,437 & 4,035 & 4,536 & 5,130 & $\ldots$ & $\ldots$ & $\ldots$ & $\ldots$ & $\ldots$ \\
\hline Export processing zone & 5,958 & 6,037 & 6,292 & 6,713 & $\ldots$ & $\ldots$ & $\ldots$ & $\ldots$ & $\ldots$ \\
\hline Other industries & 7,433 & 7,902 & 8,577 & 8,110 & $\ldots$ & $\ldots$ & $\ldots$ & $\ldots$ & $\ldots$ \\
\hline Personal, professional, and housing & 12,955 & 13,413 & 13,993 & 14,527 & $\ldots$ & $\ldots$ & $\ldots$ & $\ldots$ & $\ldots$ \\
\hline Traders & 9,815 & 8,990 & 9,285 & 9,778 & $\ldots$ & $\ldots$ & $\ldots$ & $\ldots$ & $\ldots$ \\
\hline Others & 20,508 & 26,894 & 27,888 & 29,757 & $\ldots$ & $\ldots$ & $\ldots$ & $\ldots$ & $\ldots$ \\
\hline Claims on other banklike institutions & 1,511 & 2,354 & 1,817 & 1,261 & 1,283 & 1,489 & 894 & 1,126 & 1,919 \\
\hline Demand deposits & 5,293 & 5,881 & 6,564 & 6,885 & 7,975 & 8,518 & 9,759 & 9,755 & 10,941 \\
\hline Time and savings deposits & 69,267 & 77,846 & 81,574 & 85,009 & 89,789 & 95,308 & 100,200 & 105,928 & 110,822 \\
\hline Credit from the Bank of Mauritius & 250 & 623 & 250 & 253 & 660 & 1,875 & 2,171 & 2,173 & 2,157 \\
\hline Other items (net) & 9,760 & 12,633 & 12,027 & 12,531 & 14,316 & 14,219 & 15,527 & 16,022 & 18,275 \\
\hline
\end{tabular}

Source: Bank of Mauritius. 
Table 33. Consolidated Assets and Liabilities of Category 2 Banks: 1999-2003

(In thousands of U.S. dollars; end of period)

\begin{tabular}{lrrrrr}
\hline & 1999 & 2000 & 2001 & 2002 & 2003 \\
& & & & & \\
\hline Assets & $3,120,873$ & $4,024,800$ & $3,710,400$ & $4,320,500$ & $5,802,400$ \\
$\quad$ Cash in hand and balance with banks & $2,127,073$ & $2,257,000$ & $2,131,800$ & $2,040,000$ & $2,357,900$ \\
Investments in bonds and other securities & 92,400 & 198,800 & 249,000 & 188,800 & 266,900 \\
Loans and advances to non bank customers & 879,100 & $1,531,900$ & $1,282,700$ & $2,054,900$ & $2,739,100$ \\
Bills purchased and discounted & 4,400 & 6,500 & 4,600 & 7,800 & 0 \\
Other assets & 17,900 & 30,600 & 42,300 & 29,000 & 438,500 \\
& & & & & \\
Liabilities & $3,121,100$ & $4,024,800$ & $3,710,400$ & $4,320,600$ & $5,802,400$ \\
Nonbank deposits & $1,334,300$ & $1,693,000$ & $1,586,200$ & $2,030,500$ & $2,347,100$ \\
Amounts due to banks & $1,287,700$ & $1,687,700$ & $1,681,300$ & $1,794,900$ & $2,382,700$ \\
Other liabilities & 72,900 & 145,600 & 279,100 & 258,700 & 726,900 \\
Capital and reserves & 426,200 & 498,500 & 163,800 & 236,500 & 345,700 \\
& & & & & \\
\hline
\end{tabular}

Source: Bank of Mauritius. 
Table 34. Mauritius: Principal Interest Rates, 1999-2003

(In percent per annum)

\begin{tabular}{|c|c|c|c|c|c|c|c|c|c|c|}
\hline & \multicolumn{2}{|c|}{ June 1999} & \multicolumn{2}{|c|}{ June 2000} & \multicolumn{2}{|c|}{ June 2001} & \multicolumn{2}{|c|}{ June 2002} & \multicolumn{2}{|c|}{ June 2003} \\
\hline & Min. & Max. & Min. & Max. & Min. & Max. & Min. & Max. & Min. & Max. \\
\hline \multicolumn{11}{|l|}{ Lending rates } \\
\hline \multicolumn{11}{|l|}{ Bank of Mauritius } \\
\hline Bank rate & 12.55 & 12.66 & 9.41 & 10.65 & $\ldots$ & 11.14 & $\ldots$ & 10.12 & $\ldots$ & 8.26 \\
\hline Rediscount facilities & $\ldots$ & $\ldots$ & $\ldots$ & $\ldots$ & $\ldots$ & $\ldots$ & 0.00 & $\ldots$ & 0.00 & $\ldots$ \\
\hline Lombard rate & $\ldots$ & $\ldots$ & $\ldots$ & 11.50 & $\ldots$ & 12.00 & $\ldots$ & 11.50 & $\ldots$ & 10.25 \\
\hline \multicolumn{11}{|l|}{ Commercial banks } \\
\hline Mauritius Sugar Syndicate & 12.00 & 13.50 & 9.50 & 12.50 & 10.00 & 11.50 & 10.00 & 16.00 & $\ldots$ & $\ldots$ \\
\hline Sugar industry & 10.00 & 18.00 & 9.63 & 17.50 & 10.25 & 17.50 & 10.00 & 21.00 & 8.75 & 19.75 \\
\hline Other agriculture & 11.25 & 19.50 & 10.00 & 18.50 & 10.50 & 18.75 & 10.00 & 21.00 & 8.75 & 21.00 \\
\hline Export processing zone & 10.00 & 20.00 & 10.00 & 18.50 & 10.00 & 18.50 & 9.00 & 21.00 & 7.75 & 21.00 \\
\hline Development certificates & 11.75 & 17.00 & 10.00 & 17.00 & 10.50 & 17.00 & 10.00 & 14.75 & 0.00 & 0.00 \\
\hline Small-scale industries & 12.50 & 20.00 & 10.00 & 20.00 & 10.50 & 20.00 & 10.00 & 21.00 & & \\
\hline Transport & 11.00 & 19.50 & 11.00 & 19.50 & 11.00 & 19.50 & 10.00 & 21.00 & 8.75 & 21.00 \\
\hline Hotels & 12.50 & 18.50 & 11.00 & 18.00 & 10.50 & 17.50 & 9.25 & 21.00 & 8.14 & 21.00 \\
\hline Other industries and manufacturers & 10.75 & 20.50 & 10.00 & 19.50 & 10.50 & 19.50 & 8.50 & 21.00 & 7.75 & 21.00 \\
\hline Statutory and parastatal bodies & 12.50 & 16.50 & 11.25 & 15.50 & 11.50 & 16.50 & 10.75 & 21.00 & 9.00 & 21.00 \\
\hline Housing & 12.00 & 20.50 & 10.00 & 20.50 & 10.50 & 20.50 & 10.00 & 20.75 & 8.75 & 19.50 \\
\hline Traders & 10.00 & 20.50 & 10.00 & 20.50 & 10.00 & 20.50 & 10.00 & 21.50 & 8.50 & 21.25 \\
\hline Stockbrokers & 11.00 & 18.50 & 13.75 & 16.50 & 14.50 & 16.50 & 10.75 & 15.50 & $\ldots$ & $\ldots$ \\
\hline Financial institutions & 12.00 & 18.50 & 12.00 & 17.00 & 11.00 & 16.50 & 10.00 & 21.00 & 8.75 & 21.00 \\
\hline Personal and professional & 10.00 & 24.00 & 10.00 & 20.50 & 10.50 & 20.50 & 10.00 & 21.50 & 8.50 & 21.50 \\
\hline Other customers & 10.00 & 20.50 & 10.00 & 20.50 & 11.00 & 20.50 & 10.00 & 21.00 & 8.75 & 21.00 \\
\hline \multicolumn{11}{|l|}{ Deposit rates } \\
\hline Savings & 9.00 & 9.00 & 6.50 & 8.50 & $\ldots$ & 7.00 & 6.50 & 6.50 & 5.25 & 6.00 \\
\hline Seven days' notice & 8.25 & 10.00 & 5.75 & 9.25 & 7.00 & 9.00 & 6.50 & 10.00 & 5.25 & 9.75 \\
\hline \multicolumn{11}{|l|}{ Fixed deposits } \\
\hline Up to 3 months & 9.00 & 11.50 & 6.50 & 9.87 & 7.00 & 8.75 & 6.50 & 9.50 & 5.25 & 8.25 \\
\hline Exceeding 3 and up to 6 months & 9.00 & 11.25 & 6.50 & 9.75 & 7.13 & 9.30 & 6.50 & 9.50 & 5.50 & 8.38 \\
\hline Exceeding 6 and up to 12 months & 9.00 & 12.00 & 6.88 & 10.75 & 7.25 & 11.40 & 6.50 & 11.50 & 5.63 & 10.50 \\
\hline Exceeding 12 and up to 18 months & 9.50 & 12.00 & 7.50 & 10.00 & 7.38 & 11.00 & 6.50 & 11.50 & 5.63 & 10.00 \\
\hline Exceeding 18 and up to 24 months & 9.38 & 11.50 & 7.50 & 10.50 & 7.50 & 11.00 & 7.00 & 12.00 & 5.63 & 11.00 \\
\hline Exceeding 24 and up to 36 months & 9.63 & 12.00 & 8.00 & 11.00 & 7.63 & 11.25 & 6.75 & 13.00 & 5.75 & 13.00 \\
\hline Exceeding 36 and up to 48 months & 9.63 & 12.00 & 8.00 & 11.25 & 7.75 & 11.50 & 7.25 & 13.50 & 5.25 & 13.00 \\
\hline Over 48 months & 9.75 & 11.25 & 8.75 & 10.00 & 8.00 & 11.50 & 7.25 & 13.25 & 6.00 & 13.00 \\
\hline \multicolumn{11}{|l|}{ Treasury bill rate $1 /$} \\
\hline 3-month & 12.77 & & 8.93 & & 9.44 & & 8.98 & & 7.23 & \\
\hline 6-month & 12.98 & & 10.25 & & 9.99 & & 9.54 & & 7.86 & \\
\hline 12-month & 13.10 & & 10.55 & & 11.65 & & 10.61 & & 8.75 & \\
\hline
\end{tabular}

Source: Bank of Mauritius.

1/ Rates quoted are the monthly weighted-average yields on treasury and/or Bank of Mauritius bills auctioned. 
$-115-$

Table 35. Mauritius: Balance of Payments, 1998/99-2002/03 1/

(In millions of Mauritian rupees)

\begin{tabular}{|c|c|c|c|c|c|}
\hline & 1998/99 & $1999 / 00$ & $2000 / 01$ & $\begin{array}{r}\text { 2001/02 } \\
\text { Rev. Est. }\end{array}$ & $\begin{array}{r}2002 / 03 \\
\text { Prov. }\end{array}$ \\
\hline Current account & $-1,620$ & $-1,753$ & 4,257 & 7,458 & 3,947 \\
\hline Goods & $-9,071$ & $-12,344$ & $-6,977$ & $-6,177$ & $-8,288$ \\
\hline Exports, f.o.b. & 41,702 & 38,845 & 45,222 & 47,938 & 53,450 \\
\hline Sugar & 9,226 & 5,446 & 7,529 & 8,950 & 7,828 \\
\hline Export processing zone (EPZ) & 28,179 & 29,879 & 32,476 & 32,891 & 32,497 \\
\hline Other & 4,297 & 3,520 & 5,217 & 6,097 & 13,125 \\
\hline Imports, f.o.b & $-50,773$ & $-51,189$ & $-52,199$ & $-54,115$ & $-61,738$ \\
\hline Imports, c.i.f & $-54,076$ & $-55,049$ & $-56,204$ & $-58,151$ & $-66,087$ \\
\hline Rice and flour & $-1,106$ & $-1,245$ & $-1,167$ & $-1,339$ & $-1,512$ \\
\hline Petroleum & $-2,700$ & $-4,528$ & $-5,891$ & $-5,467$ & $-6,166$ \\
\hline EPZ & $-16,175$ & $-15,836$ & $-16,771$ & $-16,756$ & $-16,226$ \\
\hline Other & $-34,095$ & $-33,440$ & $-32,375$ & $-34,589$ & $-42,183$ \\
\hline Of which: aircraft and ships & $-2,700$ & 0 & -398 & $-1,575$ & $-1,073$ \\
\hline Services (net) & 5,771 & 9,037 & 9,159 & 11,908 & 10,040 \\
\hline Transportation & $-1,006$ & $-1,095$ & $-1,003$ & -517 & $-1,733$ \\
\hline Credit & 5,060 & 5,335 & 6,401 & 7,238 & 8,915 \\
\hline Debit & $-6,066$ & $-6,430$ & $-7,404$ & $-7,755$ & $-10,648$ \\
\hline Travel & 8,127 & 9,605 & 10,691 & 12,379 & 12,587 \\
\hline Credit & 12,764 & 14,344 & 15,527 & 19,045 & 17,998 \\
\hline Debit & $-4,637$ & $-4,739$ & $-4,836$ & $-6,666$ & $-5,411$ \\
\hline Other services & $-1,350$ & 527 & -529 & 46 & -814 \\
\hline Credit & 6,211 & 7,947 & 9,360 & 9,396 & 7,207 \\
\hline Debit & $-7,561$ & $-7,420$ & $-9,889$ & $-9,350$ & $-8,021$ \\
\hline Income & -589 & -895 & 336 & -248 & -37 \\
\hline Credit & 967 & 776 & 2,018 & 1,808 & 1,811 \\
\hline Debit & $-1,556$ & $-1,671$ & $-1,682$ & $-2,056$ & $-1,848$ \\
\hline Current transfers (net) & 2,269 & 2,449 & 1,739 & 1,975 & 2,232 \\
\hline Capital and financial account & 966 & -477 & 2,488 & -367 & 3,155 \\
\hline Capital account & -16 & -12 & -40 & -30 & -57 \\
\hline Financial account & 307 & $-2,631$ & $-2,600$ & $-7,728$ & $-6,636$ \\
\hline Direct investment & 466 & 323 & 5,443 & 1,458 & 1,651 \\
\hline Abroad & -292 & -300 & -129 & -44 & 55 \\
\hline In Mauritius & 758 & 623 & 5,572 & 1,502 & 1,596 \\
\hline Portfolio investment (net) & 714 & -590 & $-3,834$ & -600 & -614 \\
\hline Other investment & -198 & -198 & 919 & $-1,195$ & 2,175 \\
\hline Assets & $-2,799$ & 1,499 & 492 & -302 & 1,553 \\
\hline Liabilities & 2,601 & $-1,697$ & 427 & -893 & 622 \\
\hline Long-term liabilities & 552 & $-1,824$ & 492 & $-1,121$ & $-2,940$ \\
\hline Government (net) & -372 & -510 & -458 & 1,070 & -76 \\
\hline Other public sector (net) & 1,354 & $-1,081$ & 1,026 & $-1,554$ & $-2,341$ \\
\hline Other long-term liabilities & -430 & -233 & -76 & -637 & -523 \\
\hline Short-term liabilities & 2,049 & 127 & -65 & 228 & 3,562 \\
\hline Reserve assets (increase -) & -675 & $-2,166$ & $-5,128$ & $-7,391$ & $-9,848$ \\
\hline Net errors and omissions & 654 & 2,230 & $-6,745$ & $-7,091$ & $-7,102$ \\
\hline
\end{tabular}

Sources: Bank of Mauritius; Ministry of Finance; and IMF staff estimates.

1/ Fiscal year from July to June. 
Table 36. Mauritius: Principal Merchandise Trade, Price Indices, and Terms of Trade, 1999-2003

\begin{tabular}{|c|c|c|c|c|c|}
\hline & 1999 & 2000 & 2001 & $\begin{array}{r}2002 \\
\text { Rev. Est. }\end{array}$ & $\begin{array}{l}2003 \\
\text { Prov. }\end{array}$ \\
\hline & \multicolumn{5}{|c|}{ (In millions of Mauritian rupees) } \\
\hline Total exports, f.o.b. & 39,160 & 39,072 & 45,622 & 51,679 & 52,120 \\
\hline Sugar & 7,602 & 5,544 & 8,557 & 8,869 & 8,430 \\
\hline Export processing zone (EPZ) & 29,131 & 30,961 & 33,695 & 32,683 & 32,059 \\
\hline Cut flowers (non-EPZ) & 124 & 133 & 139 & 88 & 73 \\
\hline Chemicals (non-EPZ) & 242 & 311 & 289 & 590 & 739 \\
\hline Other & 606 & 660 & 996 & 792 & 1,147 \\
\hline Reexports / 1 & 1,455 & 1,463 & 1,946 & 8,657 & 9,672 \\
\hline Total imports, c.i.f. & 53,929 & 54,928 & 57,835 & 64,608 & 66,389 \\
\hline Food and live animals & 6,761 & 6,948 & 8,237 & 11,289 & 10,311 \\
\hline Beverages and tobacco & 527 & 369 & 302 & 491 & 620 \\
\hline Crude materials, except fuels & 1,667 & 1,654 & 1,787 & 1,813 & 1,542 \\
\hline Mineral fuels, lubricants, etc. & 4,046 & 6,450 & 6,504 & 6,634 & 7,169 \\
\hline Animal and vegetable oils and fats & 569 & 455 & 472 & 625 & 638 \\
\hline Chemicals & 3,882 & 4,260 & 4,780 & 5,012 & 5,779 \\
\hline Manufactured goods & 17,036 & 17,570 & 17,616 & 18,744 & 18,817 \\
\hline Machinery and transport equipment & 14,445 & 12,427 & 13,004 & 13,543 & 14,865 \\
\hline Miscellaneous manufactures & 4,842 & 4,710 & 5,000 & 6,317 & 6,507 \\
\hline \multirow[t]{2}{*}{ Other } & 154 & 85 & 133 & 140 & 141 \\
\hline & \multicolumn{5}{|c|}{ (Index, 1992=100; in Mauritian rupees) } \\
\hline \multicolumn{6}{|l|}{ Price indices } \\
\hline Unit value of exports & 158 & 157 & 160 & 174 & 184 \\
\hline Unit value of imports & 156 & 161 & 173 & 182 & 195 \\
\hline Terms of trade & 101 & 97 & 92 & 96 & 94 \\
\hline Memorandum items: & \multicolumn{5}{|c|}{ (In millions of Mauritian rupees) } \\
\hline \multicolumn{6}{|l|}{ Ships' stores and bunkers } \\
\hline Exports, f.o.b. & 865 & 1,810 & 1,937 & 2,214 & 2,044 \\
\hline Imports, c.i.f. & 0 & 0 & 0 & 0 & 0 \\
\hline
\end{tabular}

Source: Central Statistics Office.

1/ As from 2002 Mauritian trade statistics include transactions of the Mauritius Freeport under "Other exports." 
Table 37. Mauritius: Pattern of Trade and Direction of Exports of the Export Processing Zone (EPZ), 1999-2003

(In millions of Mauritian rupees)

\begin{tabular}{|c|c|c|c|c|c|}
\hline & 1999 & 2000 & 2001 & $\begin{array}{r}2002 \\
\text { Rev. Est. }\end{array}$ & $\begin{array}{l}2003 \\
\text { Prov. }\end{array}$ \\
\hline Total EPZ exports by commodities, f.o.b. & 29,131 & 30,961 & 33,695 & 32,683 & 32,059 \\
\hline Clothing & 23,003 & 24,590 & 25,626 & 25,315 & 24,704 \\
\hline Other textiles & 1,829 & 1,914 & 2,473 & 1,225 & 1,137 \\
\hline Pearls and precious stones & 624 & 822 & 853 & 1,047 & 1,121 \\
\hline Watches and clocks & 585 & 498 & 407 & 333 & 395 \\
\hline Optical goods & 204 & 178 & 186 & 149 & 120 \\
\hline Toys, games, and sporting goods & 165 & 179 & 177 & 183 & 178 \\
\hline Jewelry, gold, and silver goods & 361 & 443 & 578 & 850 & 634 \\
\hline Fish and fish preparations & 952 & 945 & 1,800 & 2,018 & 2,001 \\
\hline Other & 1,408 & 1,392 & 1,595 & 1,563 & 1,769 \\
\hline Total EPZ exports by direction of exports, f.o.b. & 29,131 & 30,961 & 33,695 & 32,683 & 32,059 \\
\hline European Union (EU) countries & 19,214 & 19,845 & 20,941 & 20,538 & 20,273 \\
\hline Belgium & 833 & 809 & 643 & 727 & 674 \\
\hline France & 6,911 & 7,510 & 7,872 & 7,637 & 7,315 \\
\hline Germany & 1,567 & 1,339 & 1,463 & 1,132 & 1,191 \\
\hline Netherlands & 886 & 602 & 744 & 752 & 757 \\
\hline Sweden & 108 & 155 & 173 & 114 & 67 \\
\hline United Kingdom & 6,289 & 6,622 & 7,169 & 7,635 & 7,957 \\
\hline Other & 2,620 & 2,808 & 2,877 & 2,541 & 2,312 \\
\hline Non-EU countries & 9,917 & 11,116 & 12,754 & 12,145 & 11,786 \\
\hline Hong Kong S.A.R. & 98 & 124 & 85 & 109 & 66 \\
\hline United States & 6,824 & 7,715 & 8,804 & 9,481 & 8,785 \\
\hline Other & 2,995 & 3,277 & 3,865 & 2,555 & 2,935 \\
\hline Total EPZ imports by commodities, c.i.f. & 15,735 & 16,399 & 17,140 & 16,909 & 15,559 \\
\hline Materials & 13,891 & 14,700 & 15,637 & 15,251 & 14,061 \\
\hline Yarn and fabrics & 8,931 & 9,313 & 9,319 & 8,536 & 7,834 \\
\hline Other & 4,960 & 5,387 & 6,318 & 6,715 & 6,227 \\
\hline Machinery & 1,844 & 1,699 & 1,503 & 1,658 & 1,498 \\
\hline
\end{tabular}

Source: Central Statistics Office. 
Table 38. Mauritius: Medium- and Long-Term External Debt, June 1999-December 2003 1/

(In millions of Mauritian rupees; end of period)

\begin{tabular}{|c|c|c|c|c|c|c|c|c|c|}
\hline & \multirow{2}{*}{$\frac{1999}{\text { June }}$} & \multicolumn{2}{|c|}{2000} & \multicolumn{2}{|c|}{2001} & \multicolumn{2}{|c|}{2002} & \multicolumn{2}{|c|}{2003} \\
\hline & & June & Dec. & June & Dec. & June & Dec. & June & Dec \\
\hline Total & 30,454 & 28,767 & 27,989 & 28,056 & 28,466 & 29,954 & 27,927 & 28,753 & 26,539 \\
\hline Public sector & 26,938 & 25,483 & 24,687 & 24,848 & 25,649 & 27,382 & 25,620 & 26,703 & 24,602 \\
\hline Central government & 10,037 & 9,891 & 6,795 & 6,816 & 6,998 & 8,785 & 8,338 & 9,074 & 8,350 \\
\hline International agencies & 4,284 & 4,197 & 4,176 & 4,186 & 4,165 & 5,835 & 5,462 & 6,025 & 5,390 \\
\hline IMF credit & 0 & 0 & 0 & 0 & 0 & 0 & 0 & 0 & 0 \\
\hline Other & 4,284 & 4,197 & 4,176 & 4,186 & 4,165 & 5,835 & 5,462 & 6,025 & 5,390 \\
\hline Governments & 2,701 & 2,541 & 2,538 & 2,547 & 2,750 & 2,871 & 2,801 & 2,977 & 2,897 \\
\hline Other lenders & 3,052 & 3,153 & 81 & 83 & 83 & 79 & 75 & 72 & 63 \\
\hline Parastatal bodies & 16,901 & 15,592 & 17,892 & 18,032 & 18,651 & 18,597 & 17,282 & 17,629 & 16,252 \\
\hline International agencies & 1,953 & 1,899 & 1,940 & 1,996 & 1,978 & 1,665 & 1,537 & 1,513 & 1,413 \\
\hline Governments & 5,846 & 5,159 & 5,234 & 5,019 & 4,946 & 4,997 & 4,903 & 4,246 & 3,742 \\
\hline Other lenders & 9,102 & 8,534 & 10,718 & 11,017 & 11,727 & 11,935 & 10,842 & 11,870 & 11,097 \\
\hline Private sector & 3,516 & 3,284 & 3,302 & 3,208 & 2,817 & 2,572 & 2,307 & 2,050 & 1,937 \\
\hline
\end{tabular}

Source: Ministry of Finance.

1/ Disbursed debt outstanding with a maturity exceeding one year. 
Table 39. Mauritius: External Debt-Service Payments, 1998/99-2002/03 1/

\begin{tabular}{|c|c|c|c|c|c|}
\hline & $1998 / 99$ & $1999 / 00$ & $2000 / 01$ & $2001 / 02$ & $2002 / 03$ \\
\hline & \multicolumn{5}{|c|}{ (In millions of Mauritian rupees) } \\
\hline Government loans (1) & 2,147 & 1,385 & 4,351 & 937 & 1,035 \\
\hline Principal & 1,634 & 920 & 3,932 & 708 & 836 \\
\hline Interest and other charges & 513 & 465 & 419 & 229 & 199 \\
\hline Parastatal bodies (2) & 2,318 & 3,574 & 2,659 & 4,945 & 5,453 \\
\hline Principal & 1,500 & 2,670 & 1,703 & 4,002 & 4,627 \\
\hline Interest and other charges & 818 & 904 & 956 & 943 & 826 \\
\hline Total public debt $(1+2)$ & 4,465 & 4,959 & 7,010 & 5,882 & 6,488 \\
\hline Principal & 3,134 & 3,590 & 5,635 & 4,710 & 5,463 \\
\hline Interest and other charges & 1,331 & 1,369 & 1,375 & 1,172 & 1,025 \\
\hline Private sector debt (3) & 505 & 264 & 505 & 1,170 & 709 \\
\hline Principal & 469 & 256 & 490 & 1,152 & 679 \\
\hline Interest and other charges & 36 & 8 & 15 & 18 & 30 \\
\hline Debt service, excluding IMF $(1+2+3)$ & 4,970 & 5,223 & 7,515 & 7,052 & 7,197 \\
\hline Principal & 3,603 & 3,846 & 6,125 & 5,862 & 6,142 \\
\hline Interest and other charges & 1,367 & 1,377 & 1,390 & 1,190 & 1,055 \\
\hline International Monetary Fund (4) & 0 & 0 & 0 & 0 & 0 \\
\hline Principal & 0 & 0 & 0 & 0 & 0 \\
\hline Interest and other charges & 0 & 0 & 0 & 0 & 0 \\
\hline Total debt service $(1+2+3+4)$ & 4,970 & 5,223 & 7,515 & 7,052 & 7,197 \\
\hline Principal & 3,603 & 3,846 & 6,125 & 5,862 & 6,142 \\
\hline \multirow[t]{2}{*}{ Interest and other charges } & 1,367 & 1,377 & 1,390 & 1,190 & 1,055 \\
\hline & \multicolumn{5}{|c|}{ (In percent of exports of goods and services) } \\
\hline \multicolumn{6}{|l|}{ Debt-service ratios } \\
\hline Total debt service (including IMF) & 7.6 & 7.9 & 9.8 & 8.4 & 8.2 \\
\hline Principal & 5.5 & 5.8 & 8.0 & 7.0 & 7.0 \\
\hline \multirow[t]{2}{*}{ Interest and other charges } & 2.1 & 2.1 & 1.8 & 1.4 & 1.2 \\
\hline & \multicolumn{4}{|c|}{ (In millions of Mauritian rupees) } & 冫 \\
\hline \multicolumn{6}{|l|}{ Memorandum item: } \\
\hline Exports of goods and services & 65,737 & 66,471 & 76,510 & 83,617 & 87,547 \\
\hline
\end{tabular}

Sources: Ministry of Finance; and Bank of Mauritius.

1/ Service payments on medium- and long-term external debt; fiscal year from July to June. 
Table 40. Mauritius: Effective Exchange Rate Indices, January 1990-December 2003

(1990=100; period averages)

\begin{tabular}{|c|c|c|c|c|}
\hline & $\begin{array}{l}\text { Nominal Effective } \\
\text { Exchange Rate } \\
\text { Index }\end{array}$ & $\begin{array}{l}\text { Real Effective } \\
\text { Exchange Rate } \\
\text { Index }\end{array}$ & $\begin{array}{l}\text { Consumer } \\
\text { Price } \\
\text { Index }\end{array}$ & $\begin{array}{l}\text { Relative } \\
\text { Price } \\
\text { Index }\end{array}$ \\
\hline 1990 & 100.0 & 100.0 & 100.0 & 100.0 \\
\hline 1991 & 96.7 & 98.7 & 107.0 & 102.0 \\
\hline 1992 & 94.9 & 97.0 & 112.0 & 102.2 \\
\hline 1993 & 89.6 & 97.6 & 123.8 & 109.0 \\
\hline 1994 & 87.2 & 98.6 & 132.8 & 113.1 \\
\hline 1995 & 83.3 & 96.7 & 140.8 & 116.1 \\
\hline 1996 & 77.3 & 93.0 & 150.1 & 120.4 \\
\hline 1997 & 79.0 & 99.2 & 160.3 & 125.5 \\
\hline 1998 & 72.7 & 95.5 & 171.2 & 131.5 \\
\hline 1999 & 70.3 & 97.8 & 183.0 & 139.1 \\
\hline 2000 & 73.2 & 104.0 & 190.7 & 141.9 \\
\hline 2001 & 69.3 & 101.6 & 201.0 & 146.5 \\
\hline 2002 & 66.4 & 101.8 & 214.5 & 153.2 \\
\hline 2003 & 62.7 & 98.2 & 223.6 & 156.6 \\
\hline $1998 \mathrm{I}$ & 0.0 & 98.7 & 165.7 & 128.1 \\
\hline 1998 II & 0.0 & 95.7 & 169.6 & 130.5 \\
\hline 1998 III & 0.0 & 95.8 & 172.6 & 132.3 \\
\hline 1998 IV & 98.4 & 92.0 & 177.1 & 135.3 \\
\hline $1999 \mathrm{I}$ & 69.3 & 94.9 & 179.4 & 136.9 \\
\hline $1999 \mathrm{II}$ & 71.1 & 98.5 & 182.0 & 138.6 \\
\hline 1999 III & 70.7 & 99.1 & 184.6 & 140.2 \\
\hline 1999 IV & 70.2 & 98.8 & 186.2 & 140.7 \\
\hline $2000 \mathrm{I}$ & 71.6 & 101.2 & 188.1 & 141.2 \\
\hline $2000 \mathrm{II}$ & 73.6 & 104.2 & 189.5 & 141.5 \\
\hline $2000 \mathrm{III}$ & 74.2 & 104.6 & 190.1 & 141.0 \\
\hline $2000 \mathrm{IV}$ & 73.4 & 105.8 & 195.3 & 144.0 \\
\hline $2001 \mathrm{I}$ & 70.0 & 101.1 & 197.3 & 144.4 \\
\hline $2001 \mathrm{II}$ & 71.2 & 103.2 & 198.6 & 145.0 \\
\hline $2001 \mathrm{III}$ & 68.5 & 101.2 & 203.1 & 147.6 \\
\hline $2001 \mathrm{IV}$ & 67.6 & 100.9 & 205.0 & 149.1 \\
\hline 2002 I & 69.1 & 104.4 & 210.3 & 151.1 \\
\hline 2002 II & 66.8 & 101.8 & 212.3 & 152.4 \\
\hline 2002 III & 64.9 & 100.1 & 216.3 & 154.2 \\
\hline 2002 IV & 64.9 & 100.7 & 219.1 & 155.1 \\
\hline 2003 I & 65.4 & 101.3 & 220.6 & 154.8 \\
\hline 2003 II & 64.4 & 100.8 & 222.3 & 156.4 \\
\hline 2003 III & 60.8 & 95.7 & 224.8 & 157.4 \\
\hline $2003 \mathrm{IV}$ & 60.2 & 95.1 & 226.7 & 158.0 \\
\hline 2004 I & 63.2 & 100.5 & 229.7 & 158.9 \\
\hline 2002 January & 68.9 & 103.5 & 208.7 & 150.2 \\
\hline 2002 February & 69.4 & 104.9 & 210.6 & 151.2 \\
\hline 2002 March & 69.0 & 105.0 & 211.6 & 152.0 \\
\hline 2002 April & 68.4 & 104.3 & 212.0 & 152.4 \\
\hline 2002 May & 66.6 & 101.7 & 212.4 & 152.7 \\
\hline 2002 June & 65.4 & 99.4 & 212.4 & 152.1 \\
\hline 2002 July & 64.1 & 98.5 & 215.4 & 153.6 \\
\hline 2002 August & 65.3 & 100.7 & 216.4 & 154.3 \\
\hline 2002 September & 65.4 & 101.2 & 217.2 & 154.6 \\
\hline 2002 October & 65.5 & 101.9 & 219.3 & 155.4 \\
\hline 2002 November & 65.0 & 100.9 & 219.1 & 155.1 \\
\hline 2002 December & 64.1 & 99.3 & 218.9 & 154.9 \\
\hline 2003 January & 64.0 & 99.1 & 220.4 & 154.9 \\
\hline 2003 February & 65.7 & 101.8 & 220.8 & 154.8 \\
\hline 2003 March & 66.5 & 102.9 & 220.6 & 154.7 \\
\hline 2003 April & 67.0 & 104.2 & 221.0 & 155.5 \\
\hline 2003 May & 64.3 & 100.8 & 222.5 & 156.8 \\
\hline 2003 June & 62.1 & 97.5 & 223.3 & 157.0 \\
\hline 2003 July & 60.0 & 94.5 & 224.6 & 157.4 \\
\hline 2003 August & 61.3 & 96.4 & 224.3 & 157.1 \\
\hline 2003 September & 61.0 & 96.2 & 225.4 & 157.5 \\
\hline 2003 October & 59.9 & 94.4 & 226.2 & 157.6 \\
\hline 2003 November & 60.3 & 95.3 & 226.4 & 157.9 \\
\hline 2003 December & 60.3 & 95.5 & 227.5 & 158.4 \\
\hline
\end{tabular}

Source: IMF, Information Notice System. 


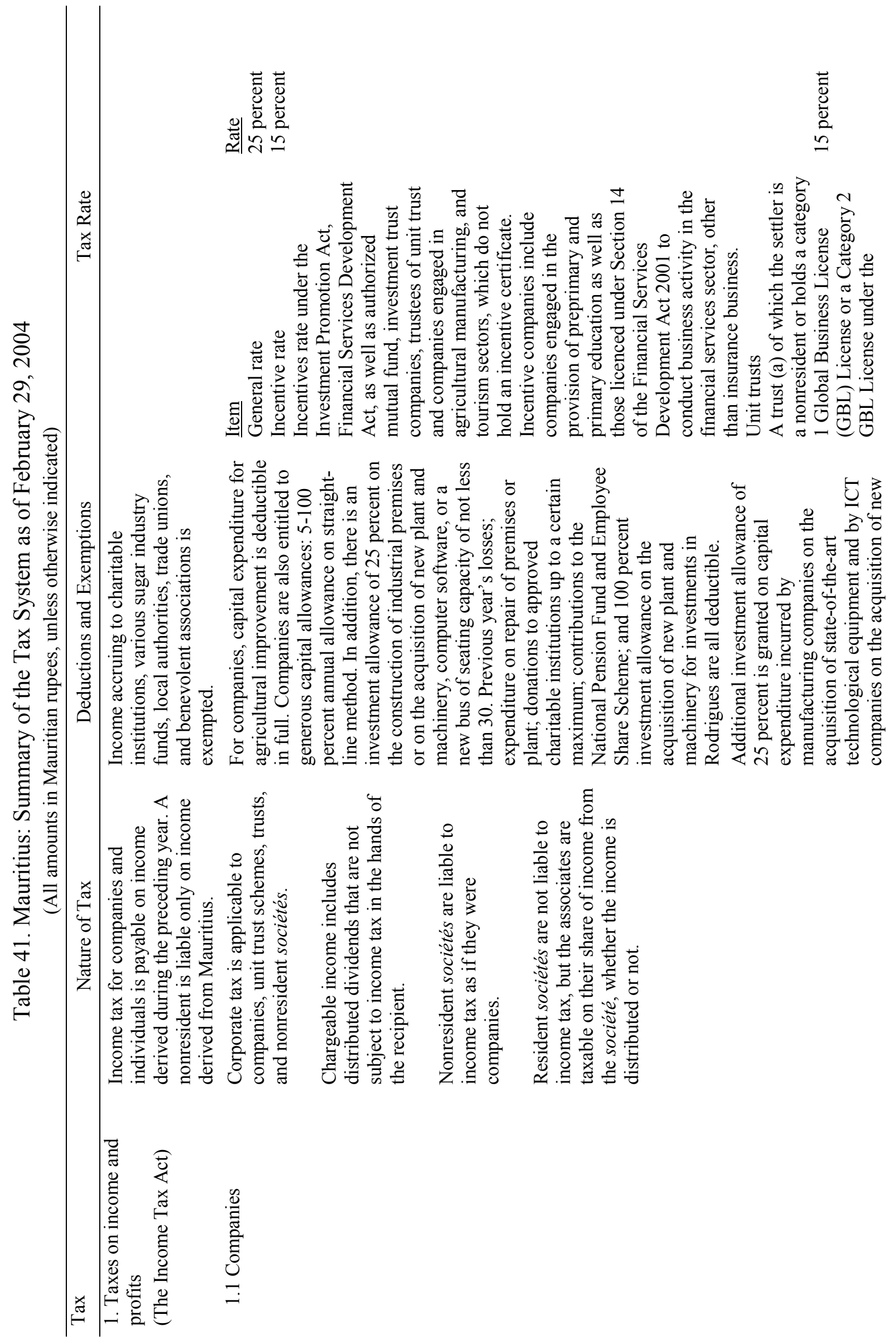




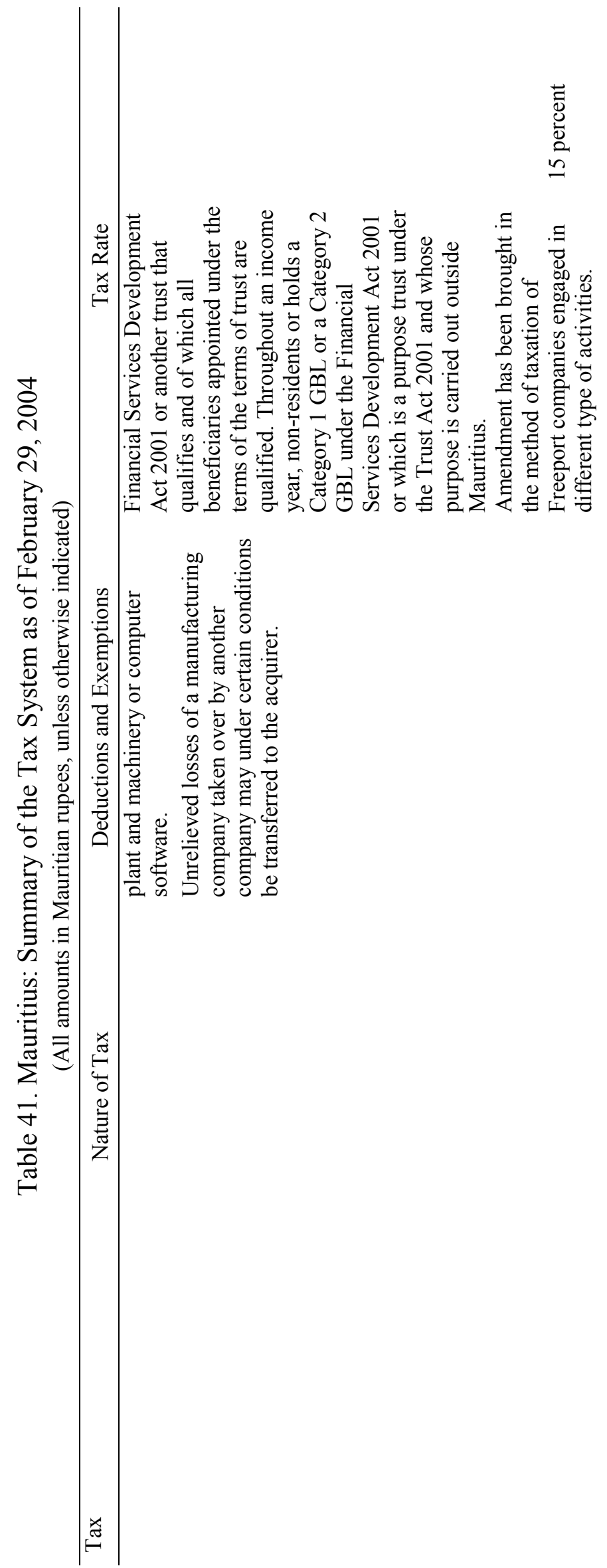




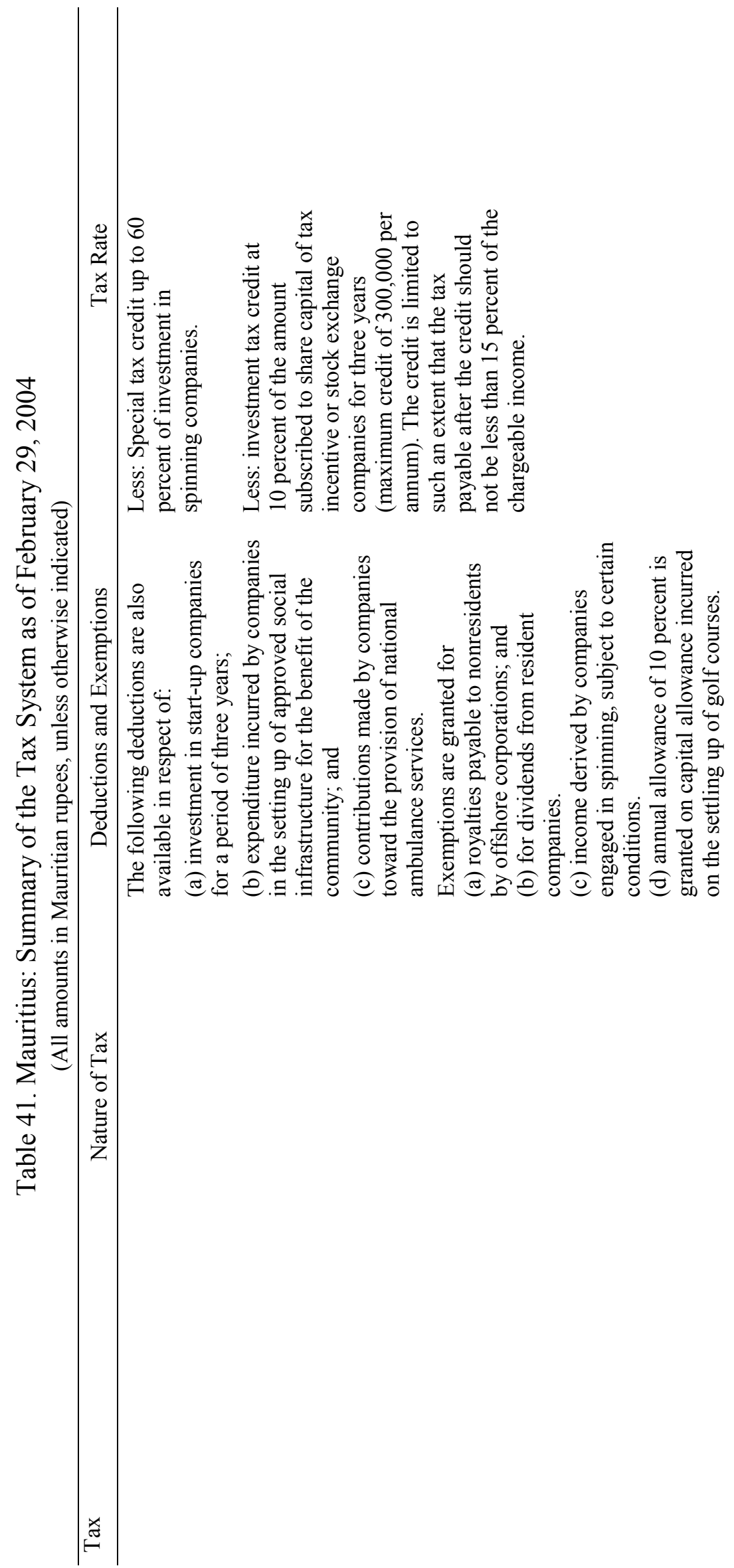




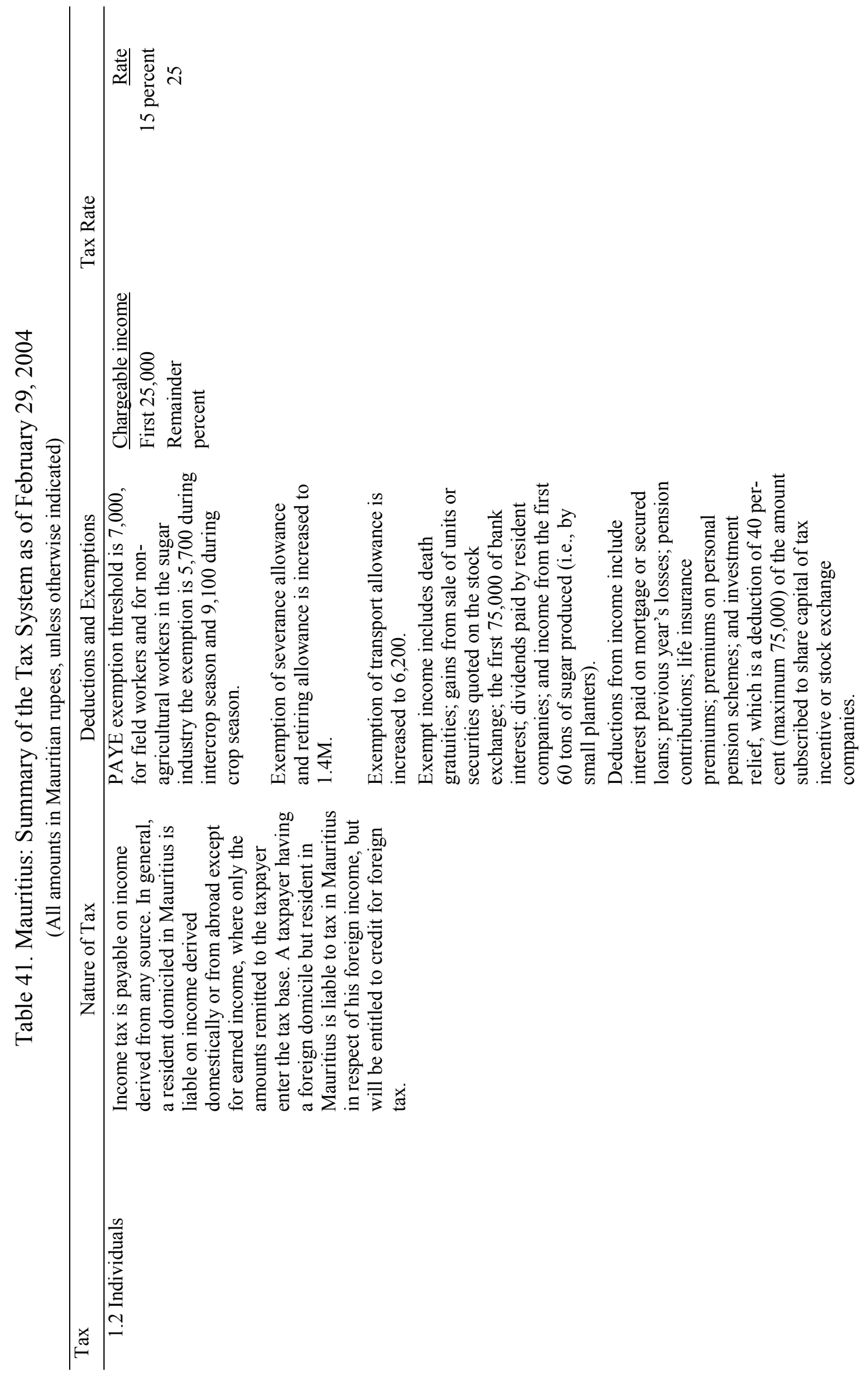




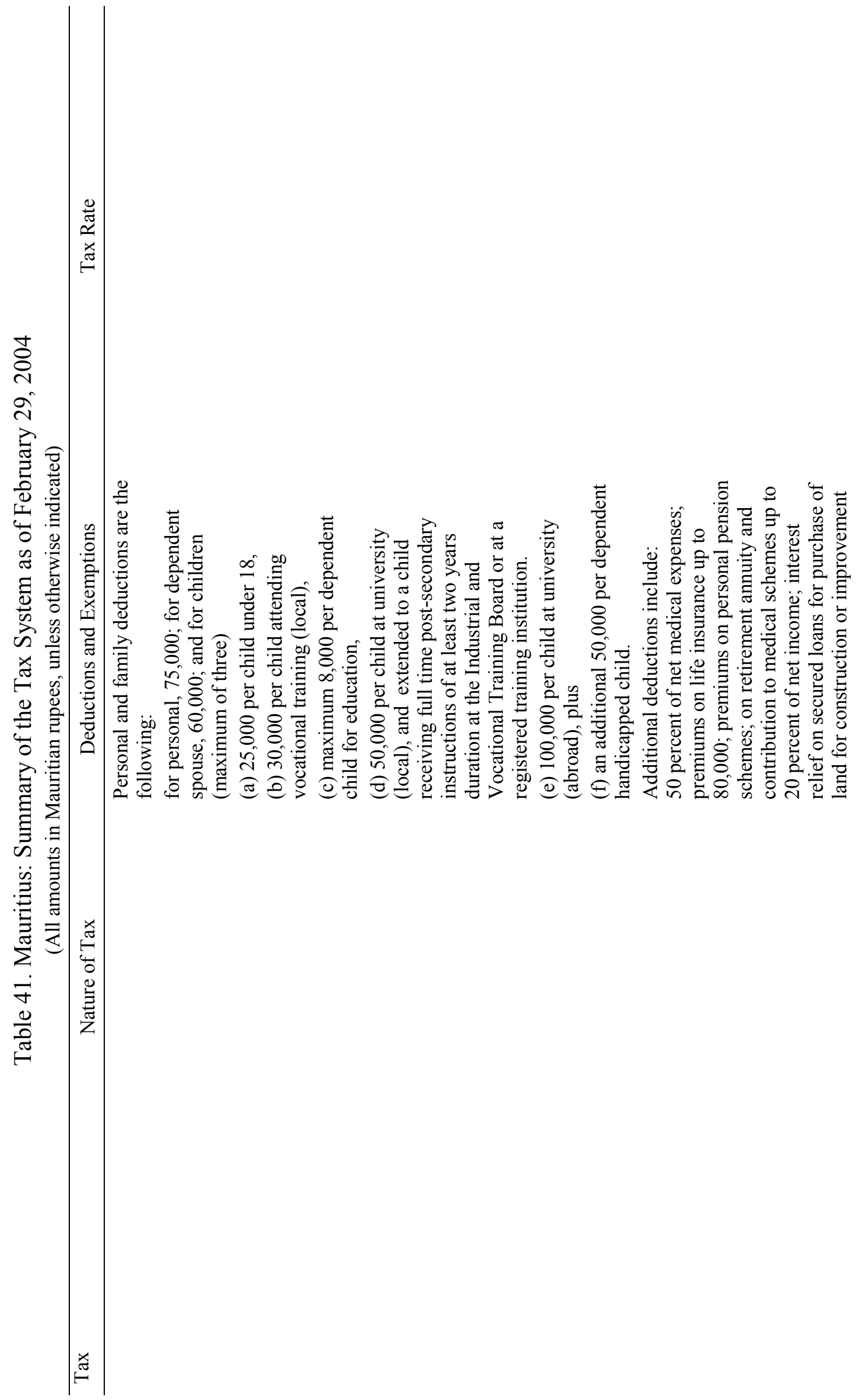




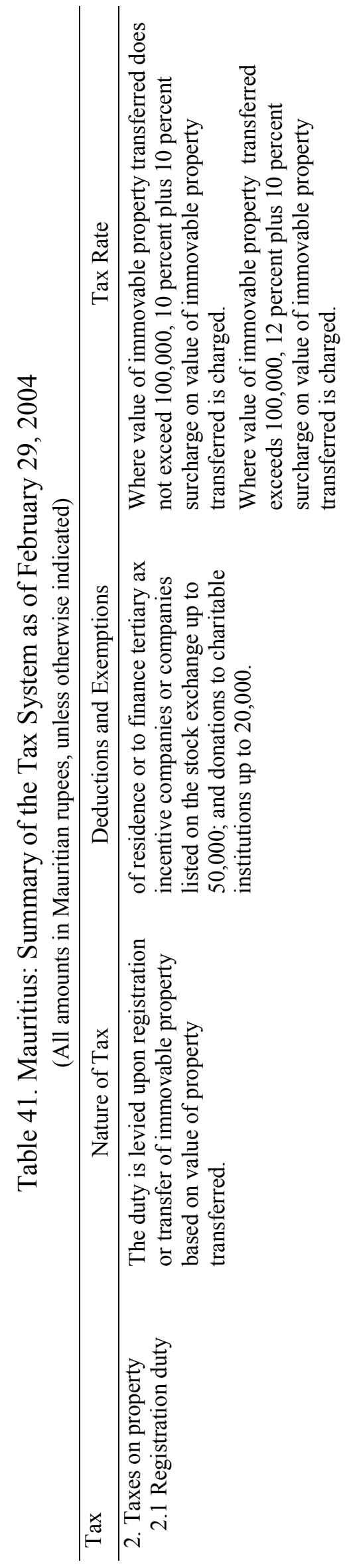




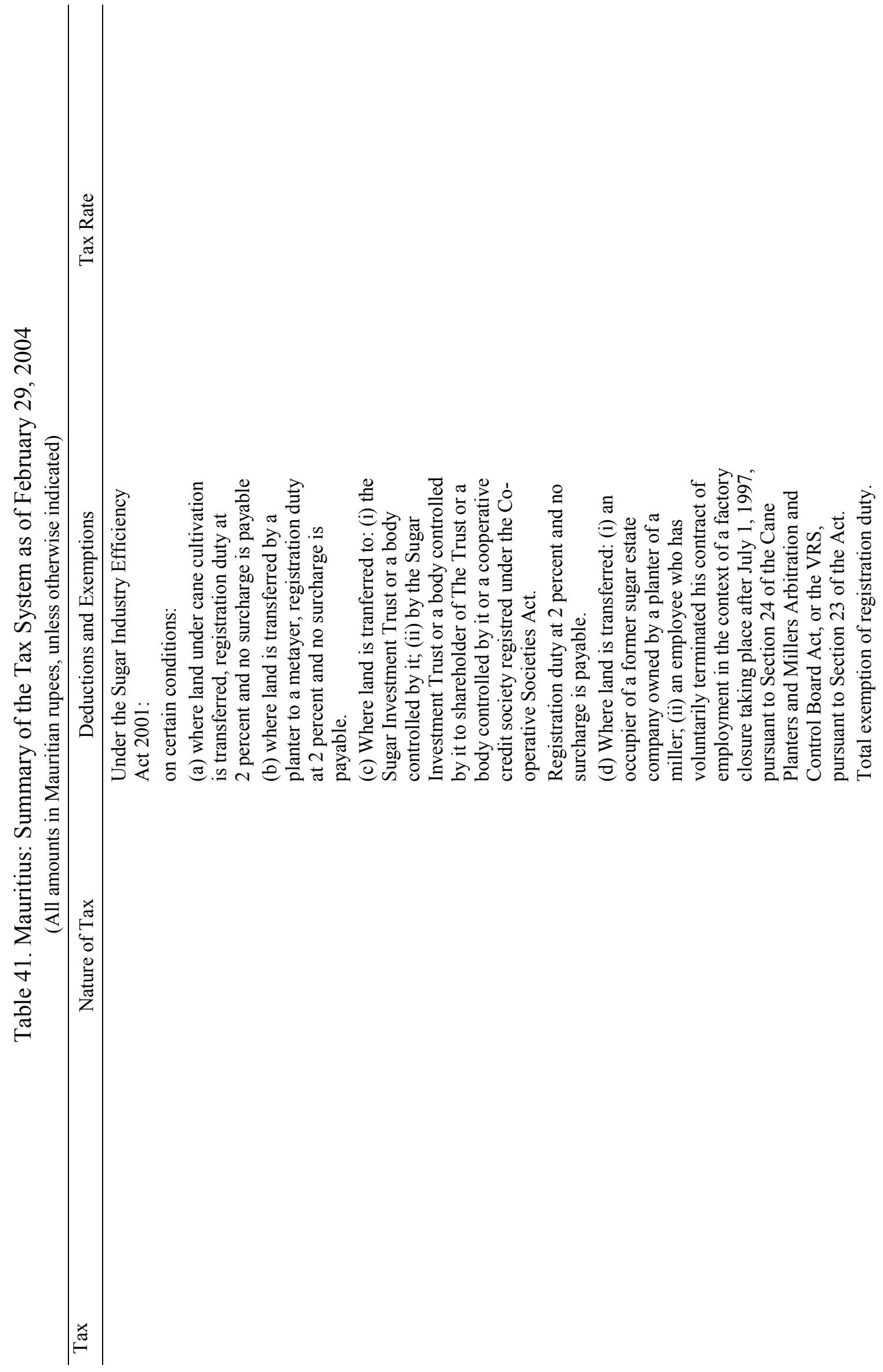




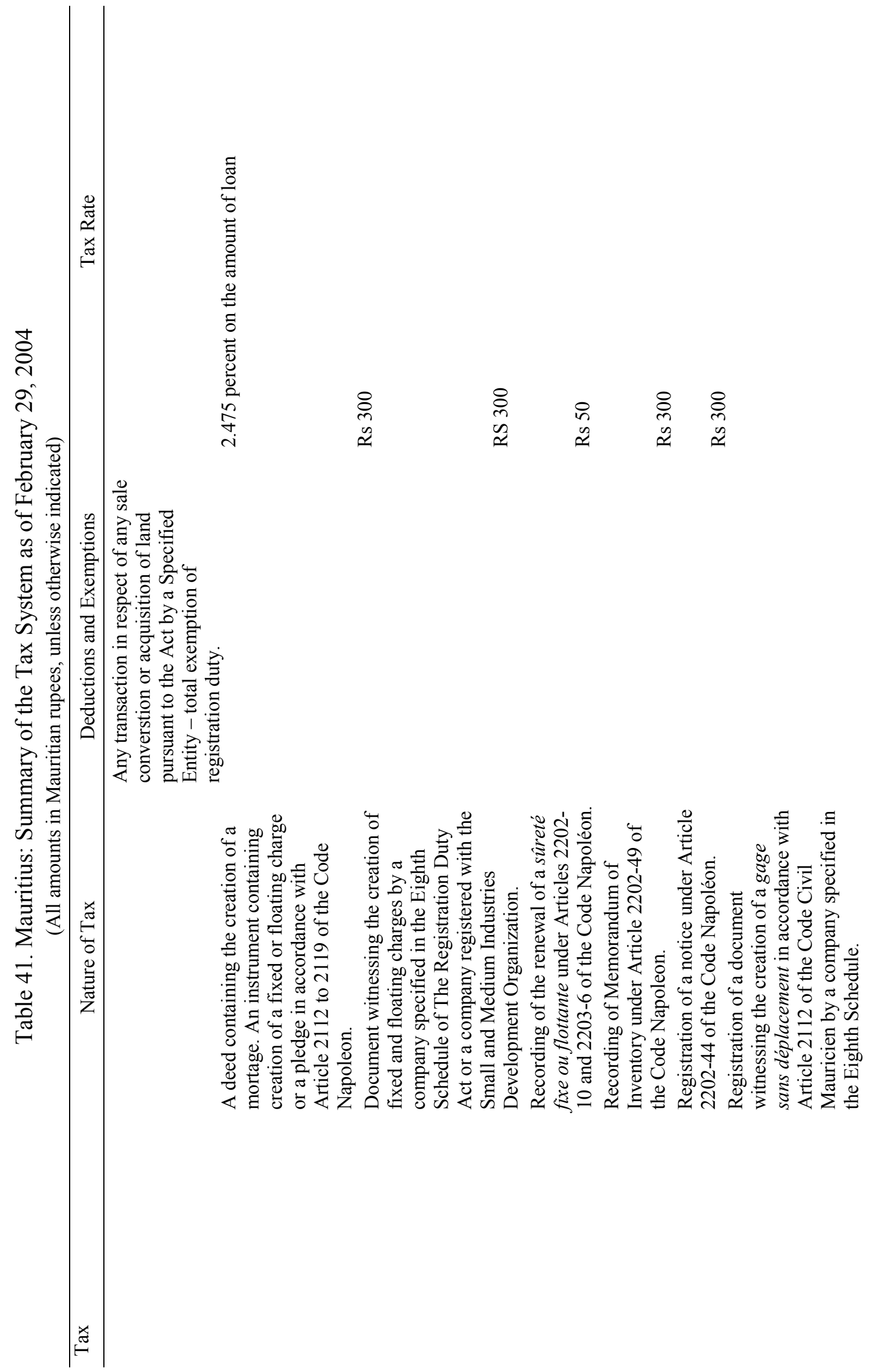




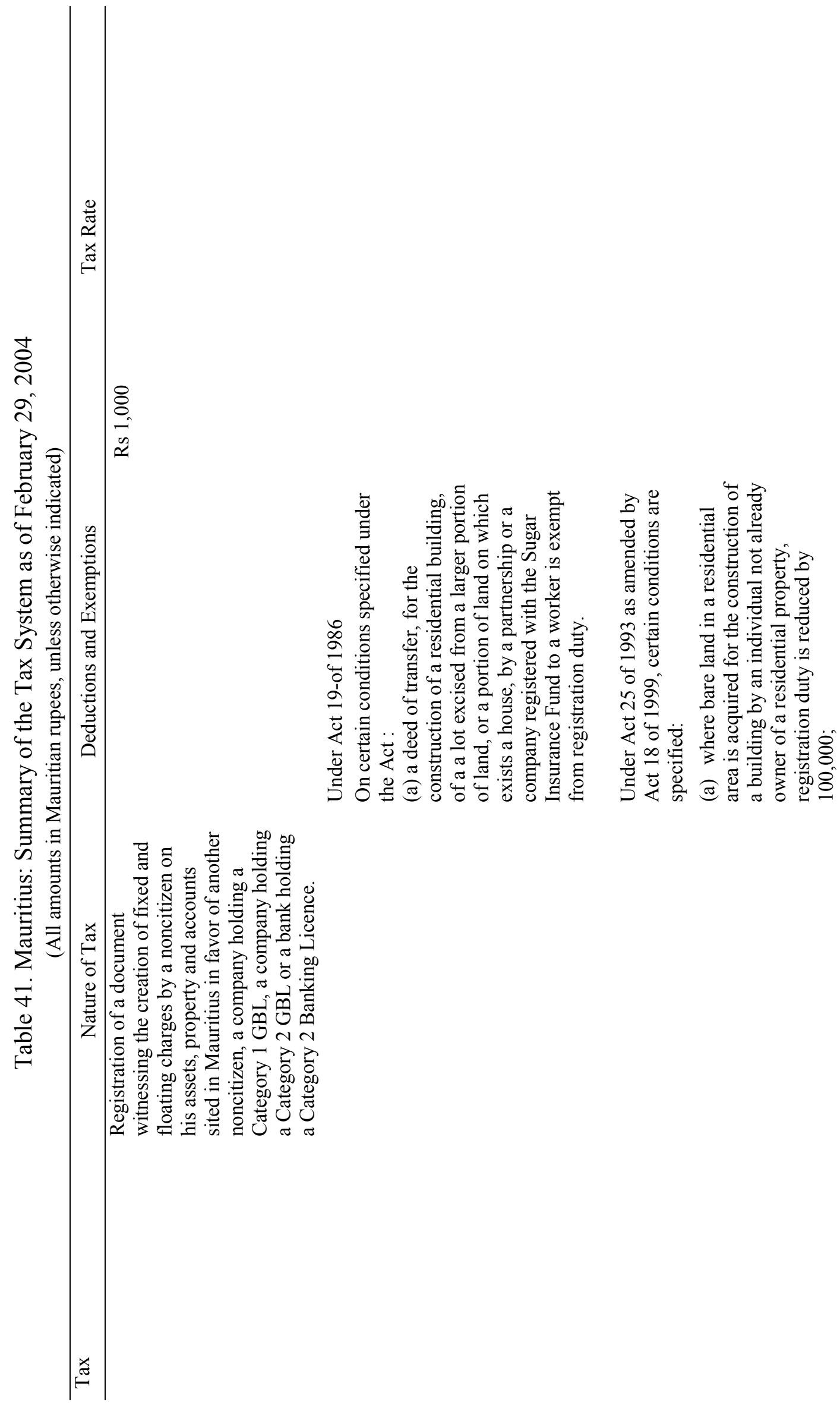




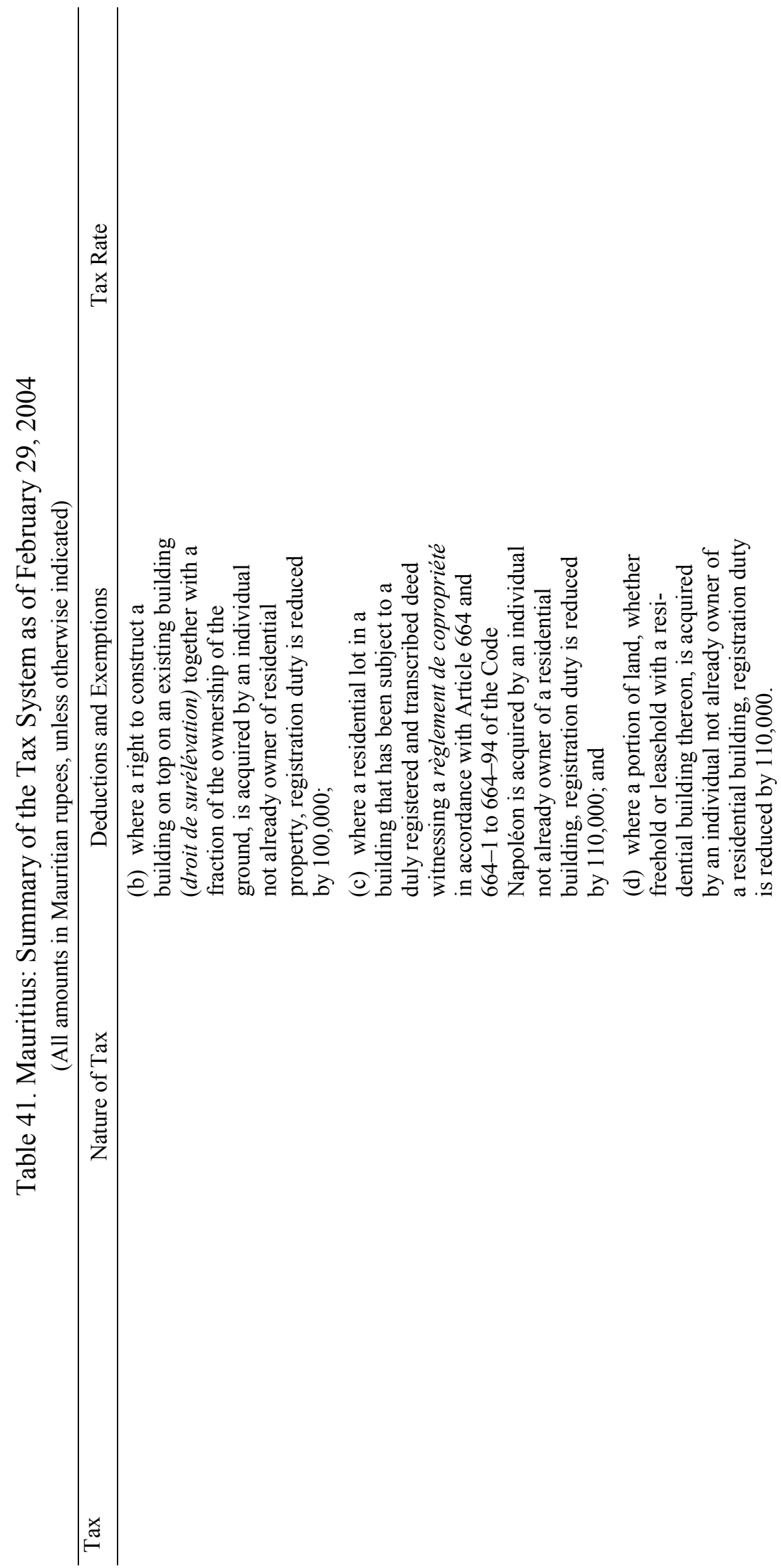




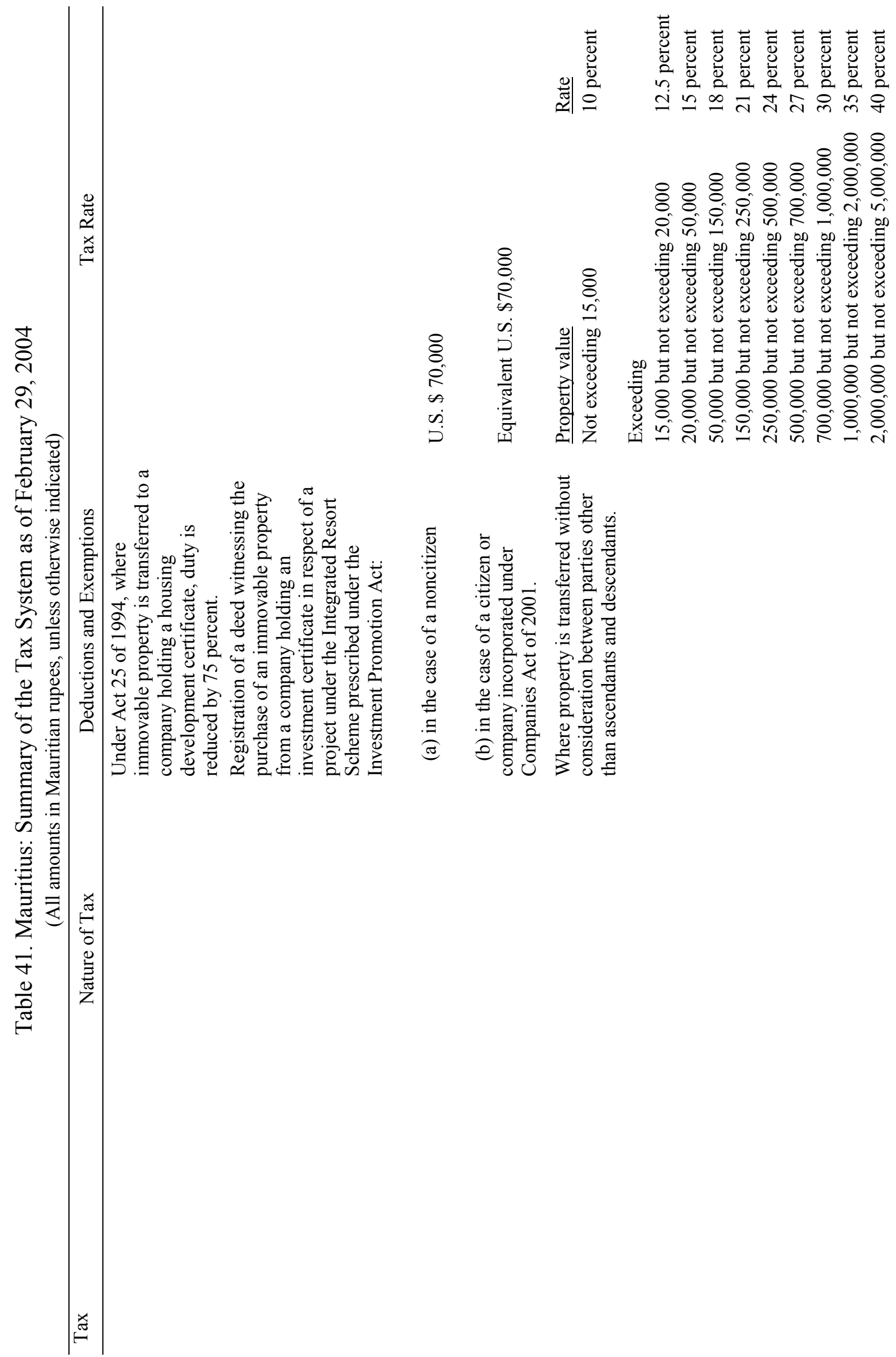




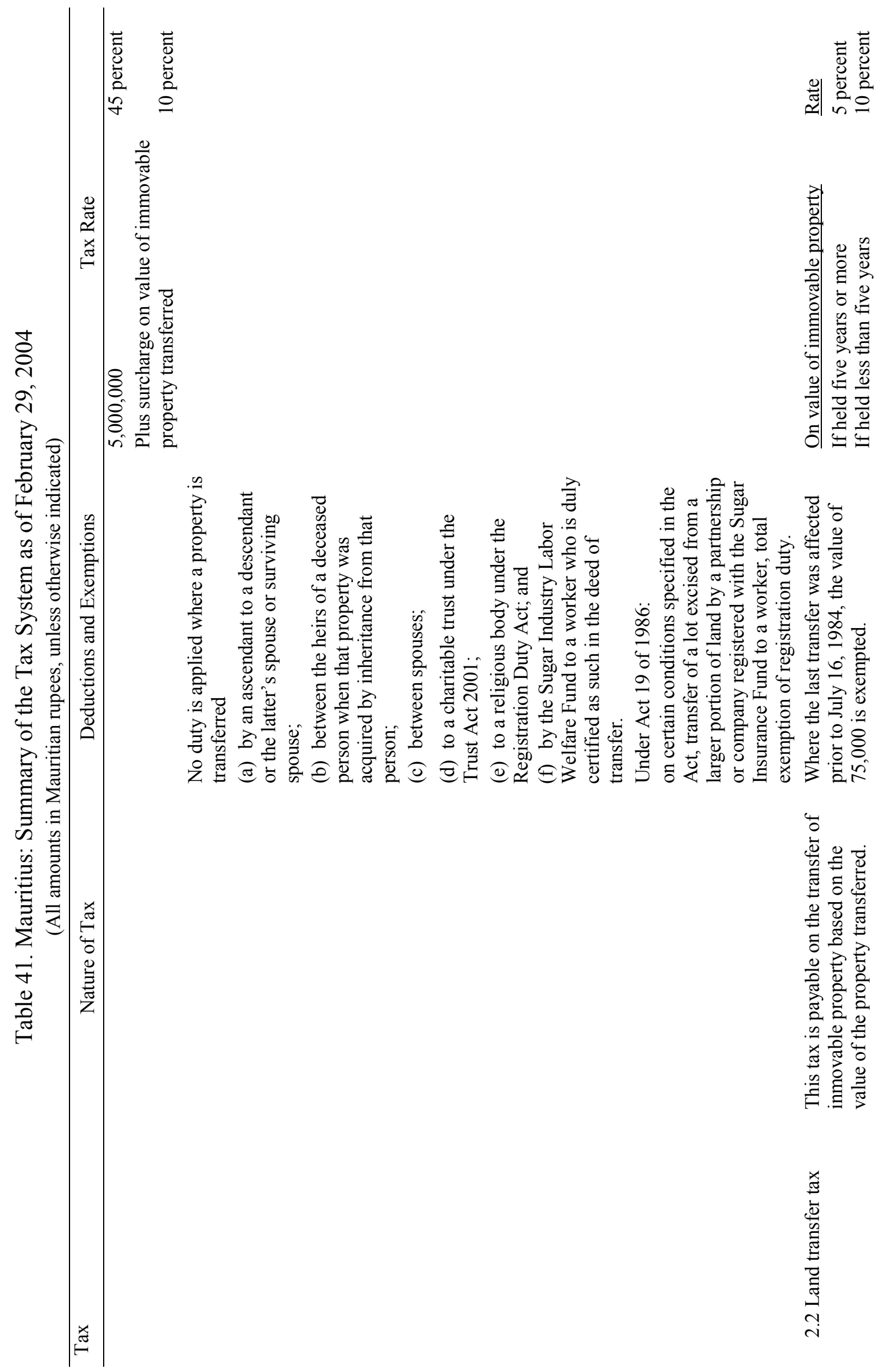




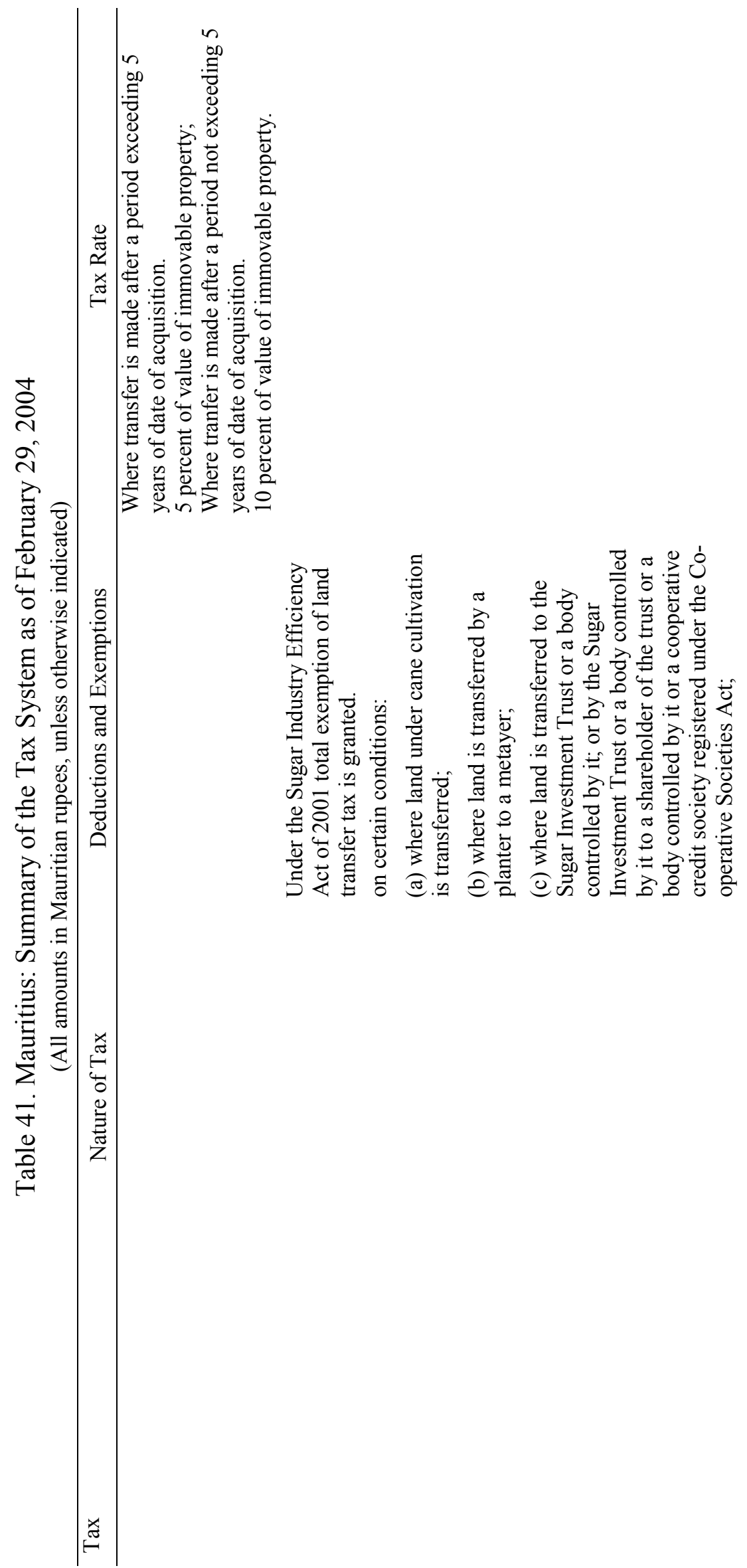



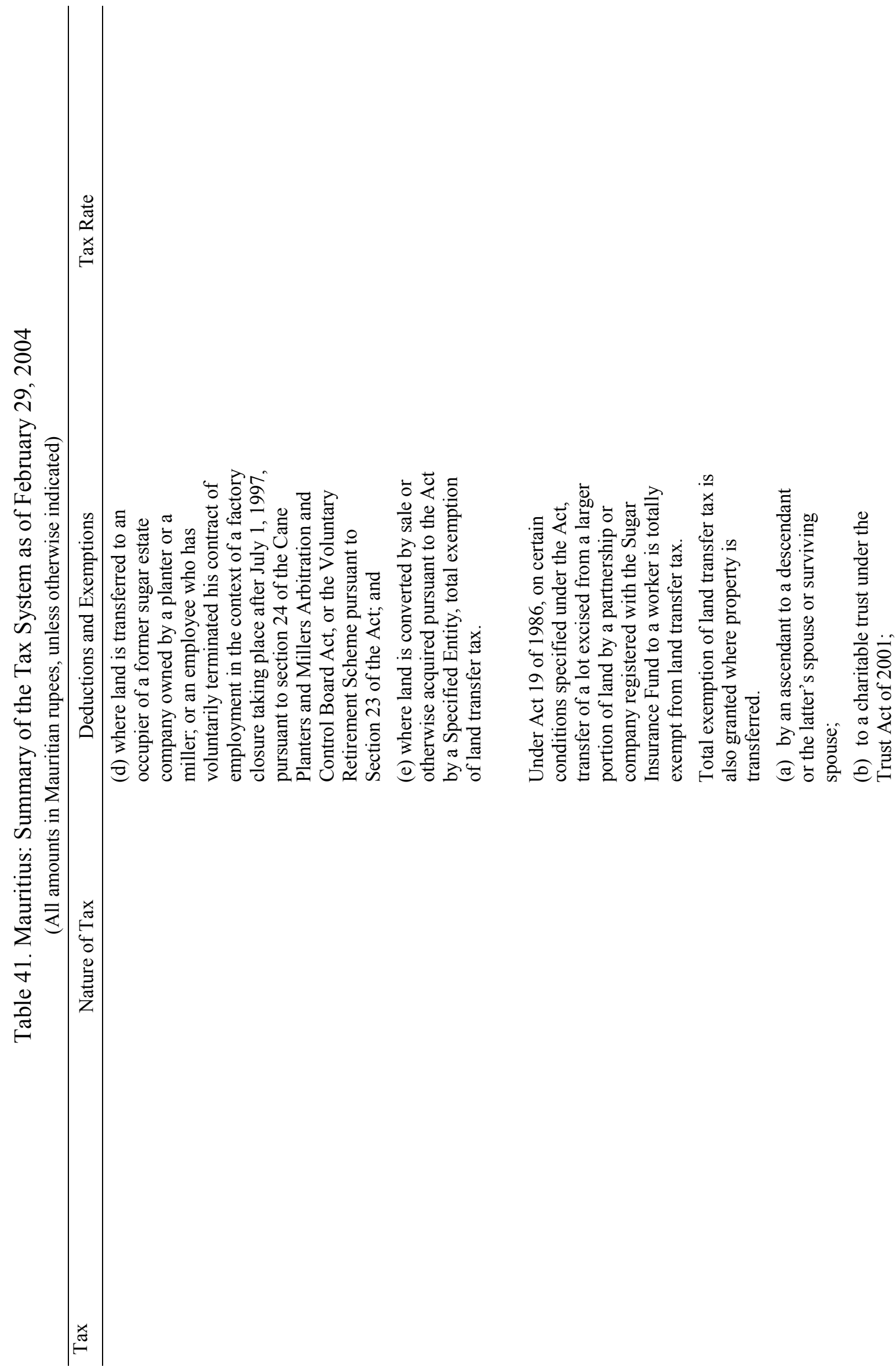


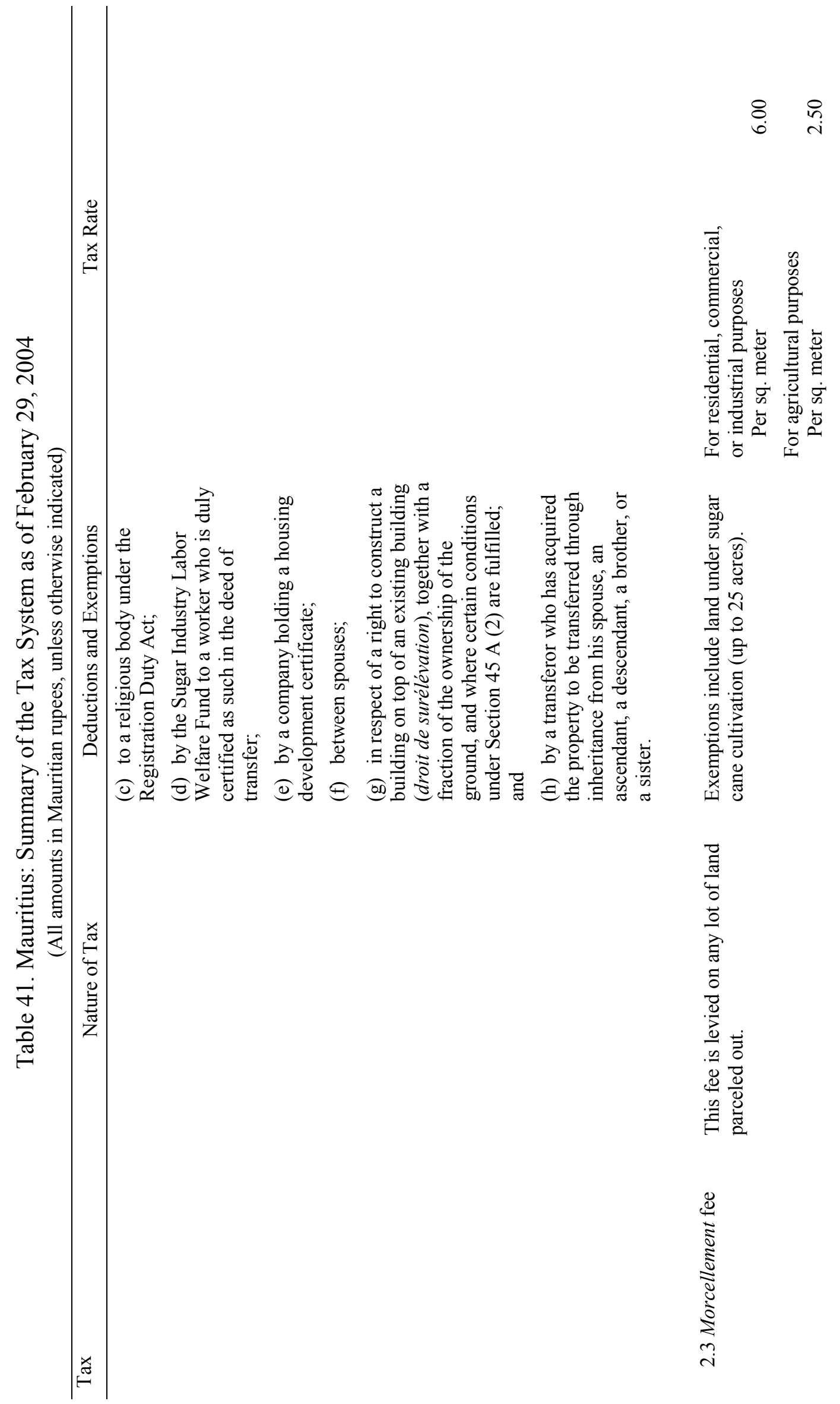




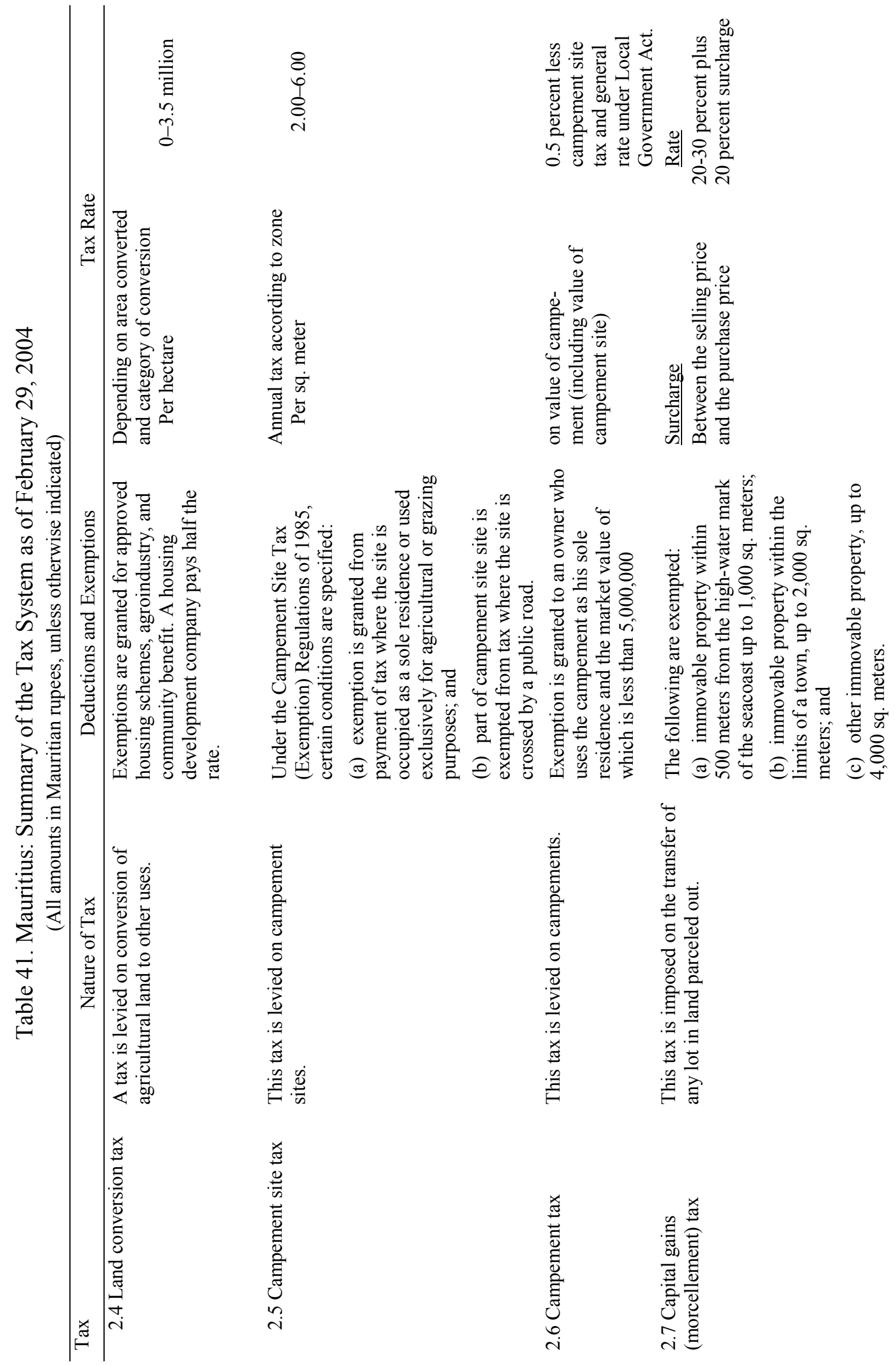




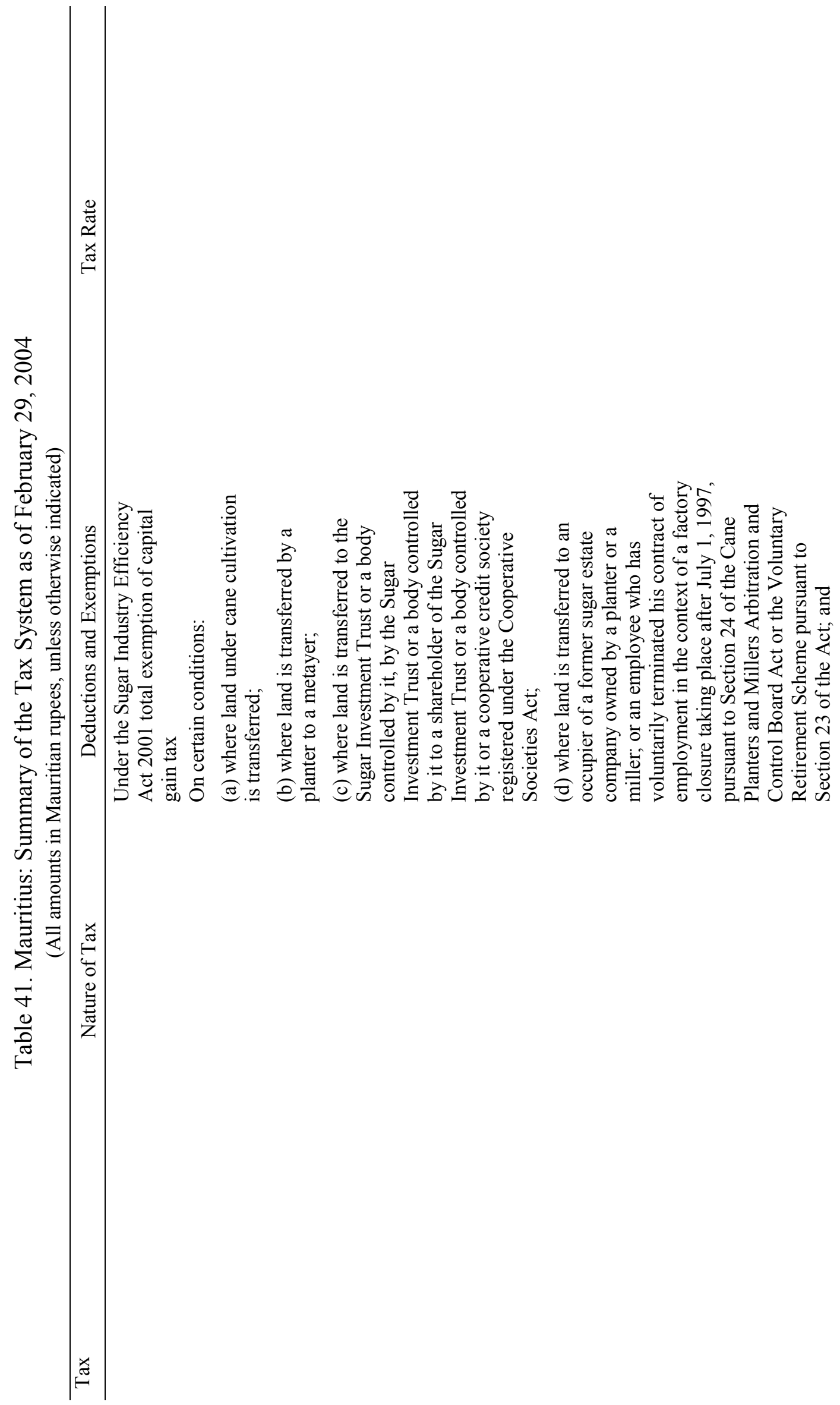


- 138 -

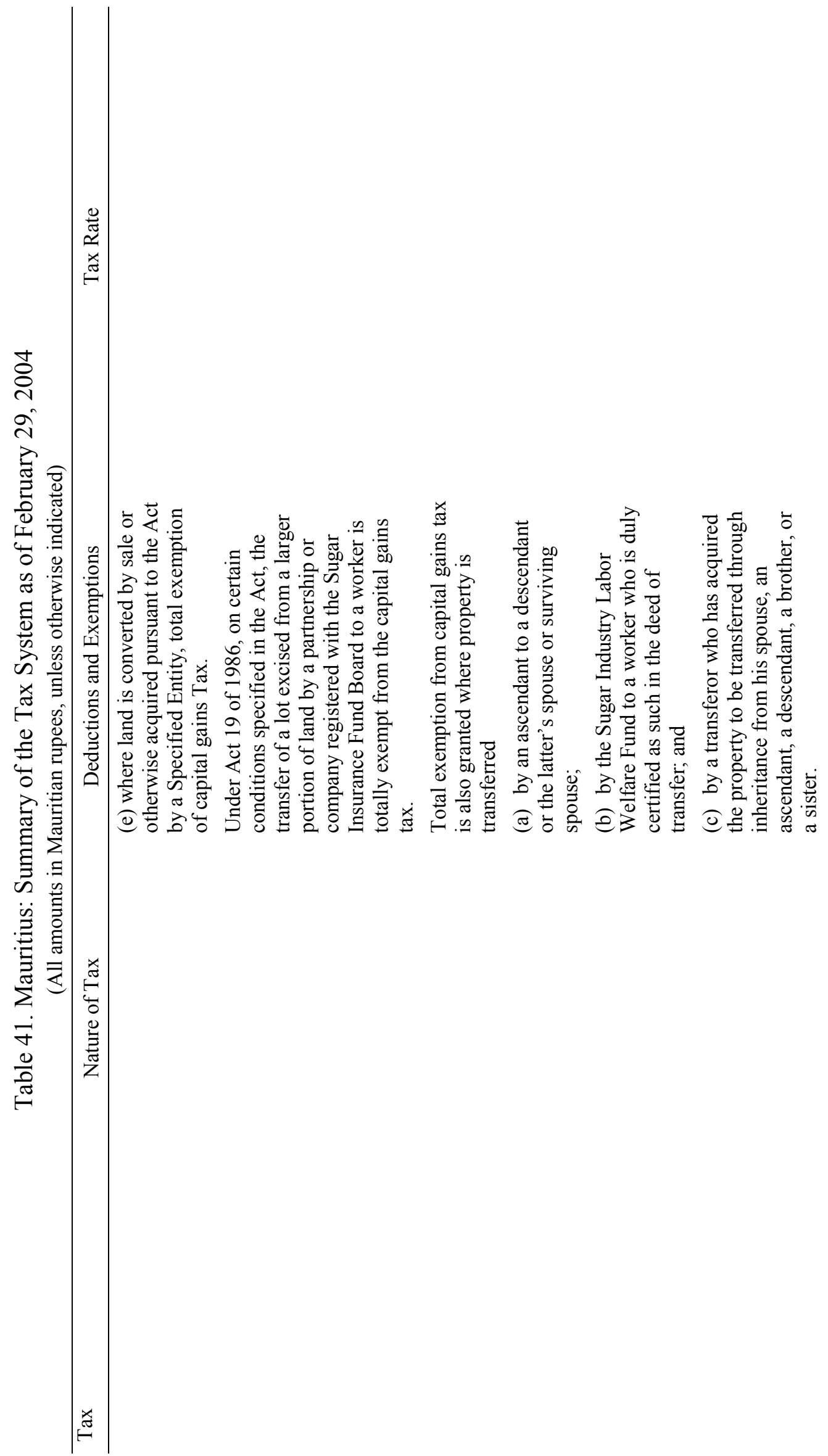




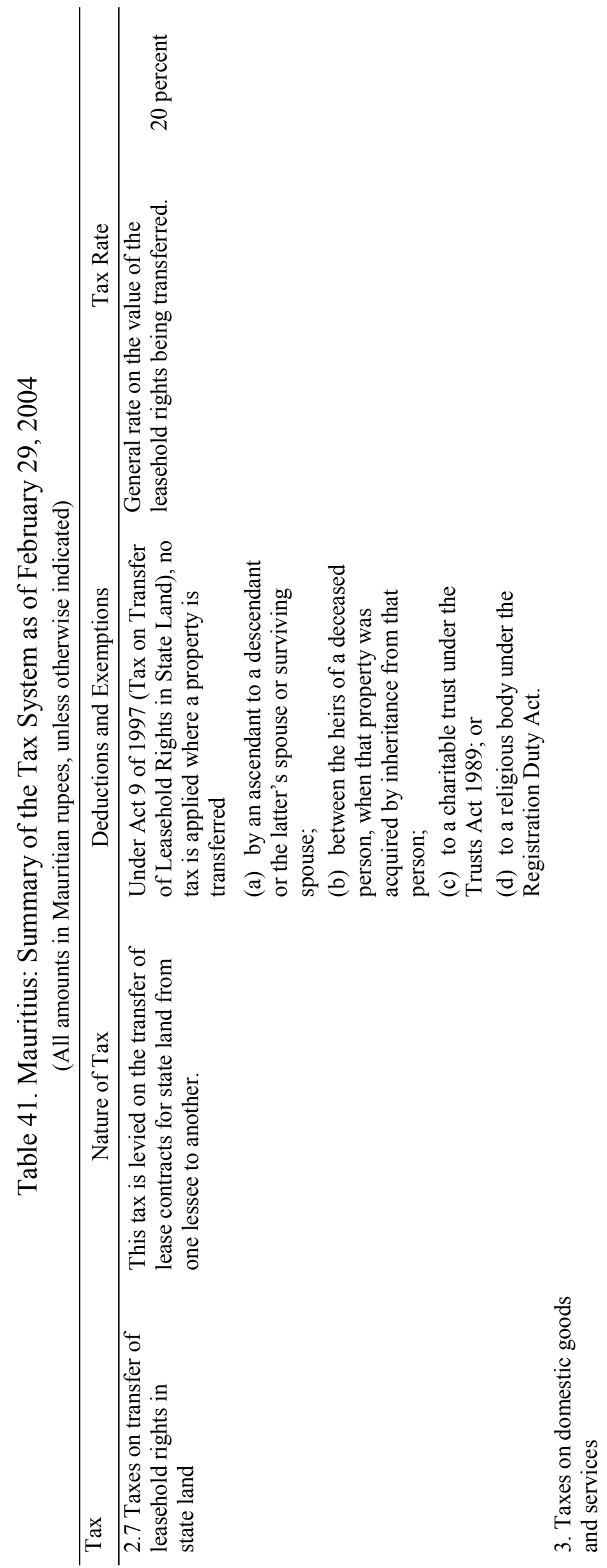




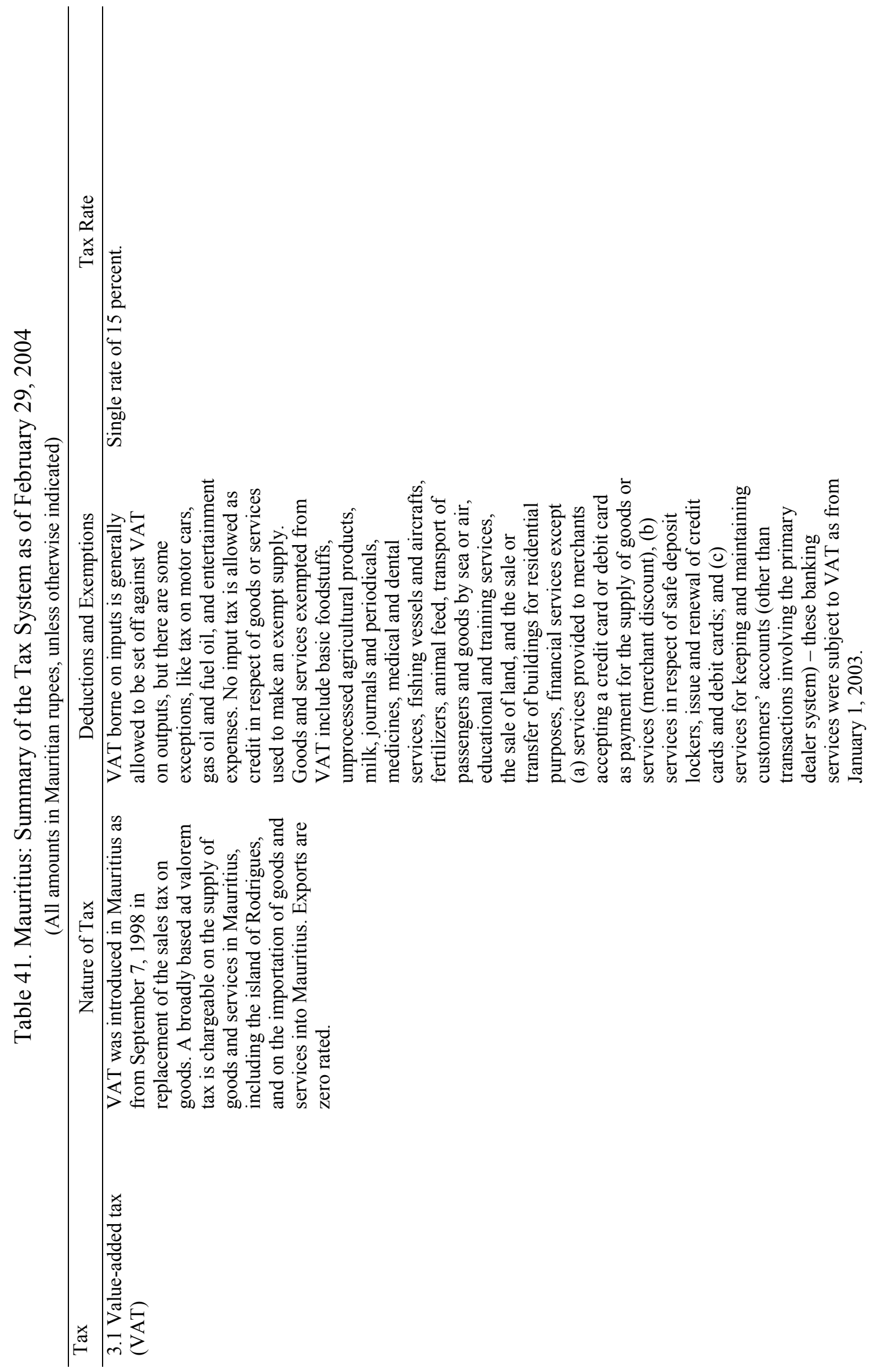




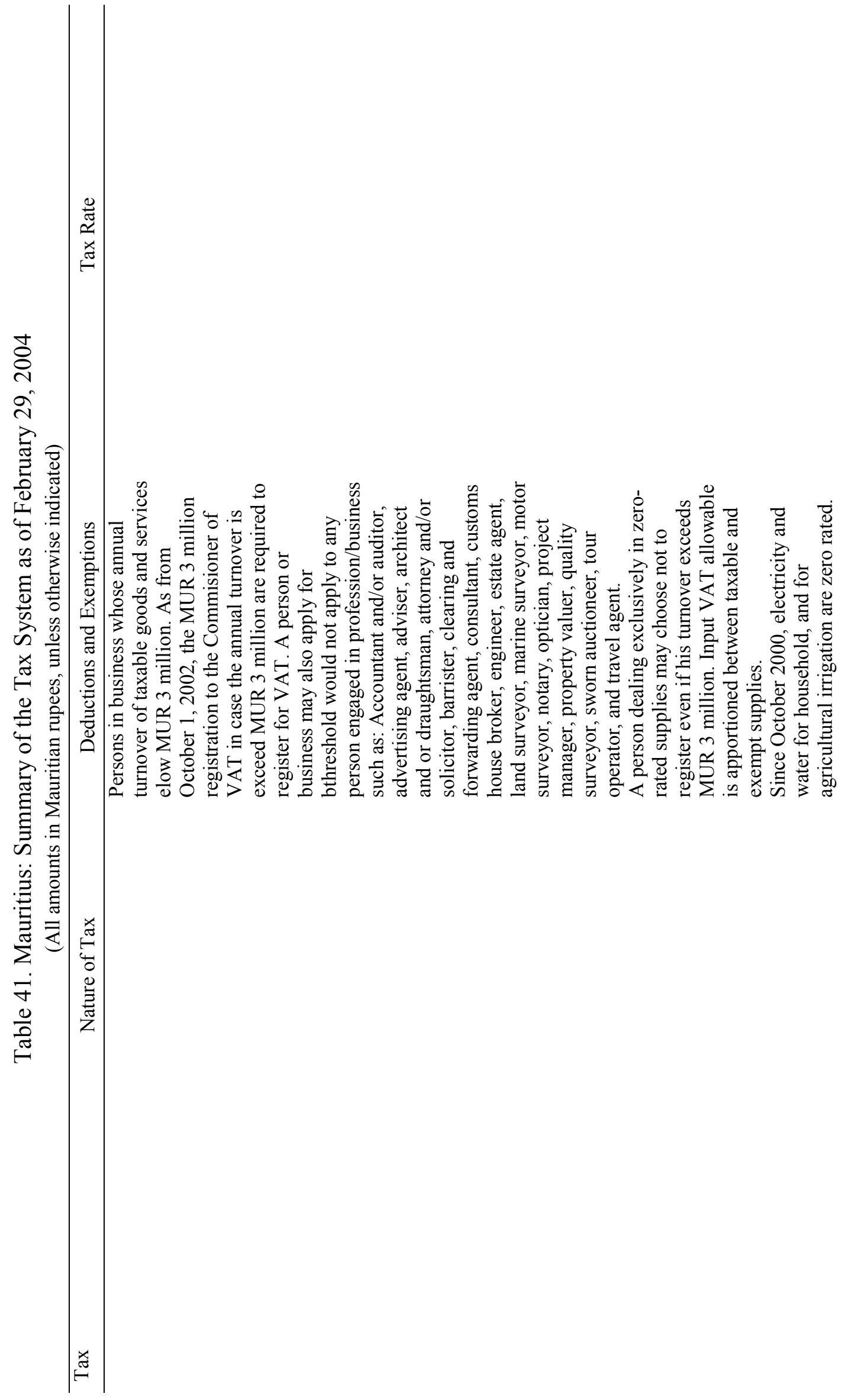



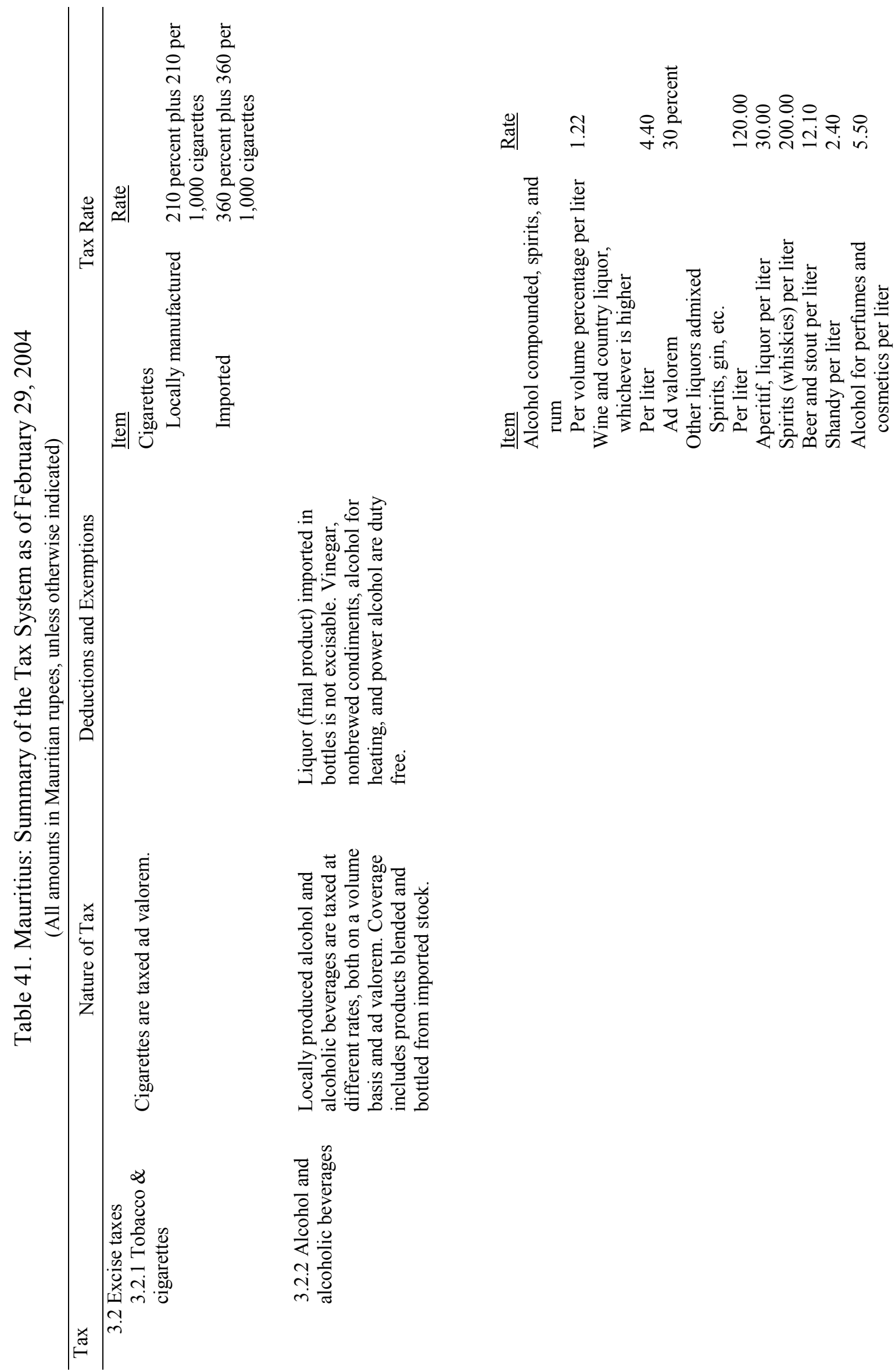

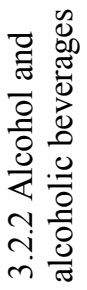


- 143 -

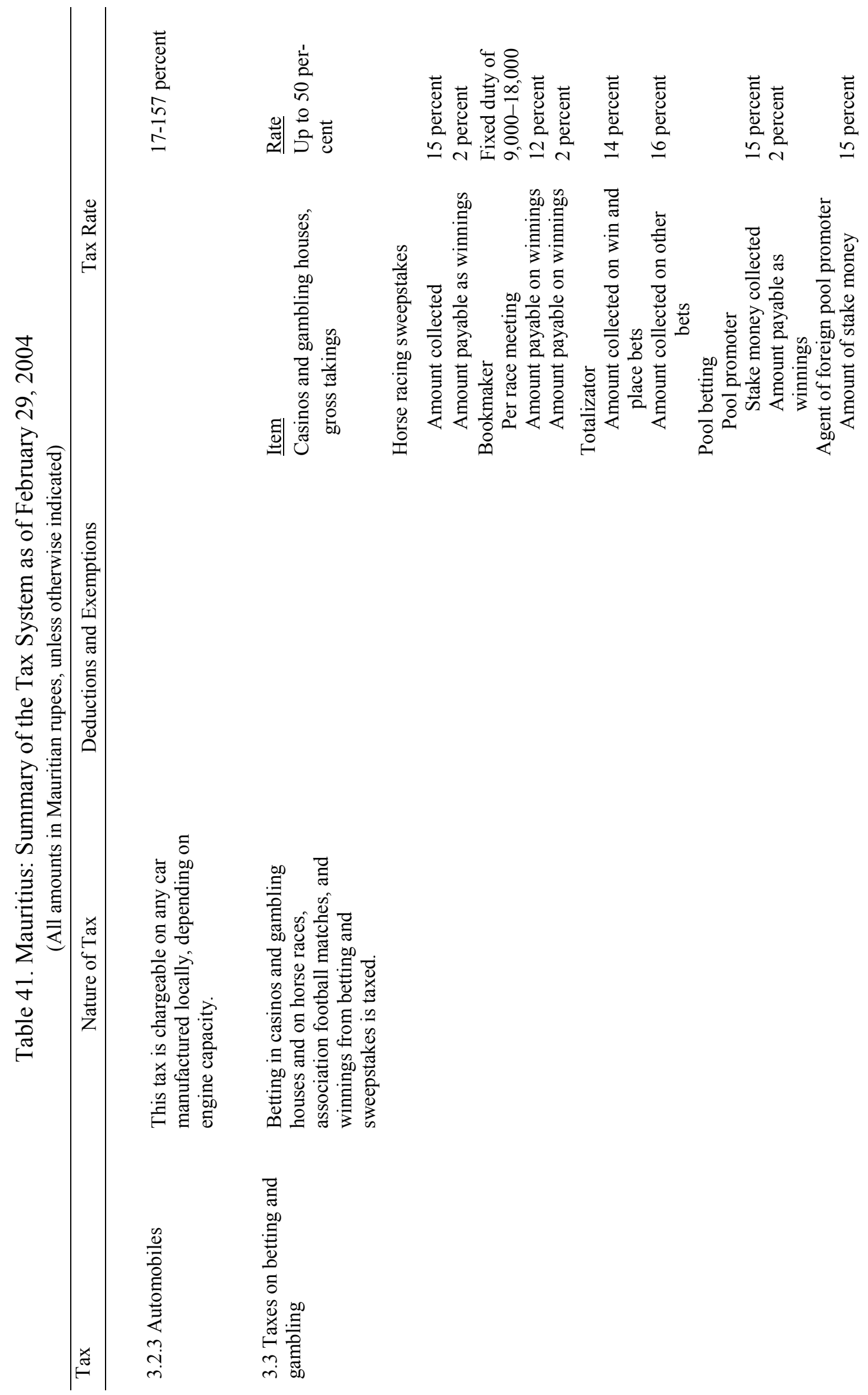




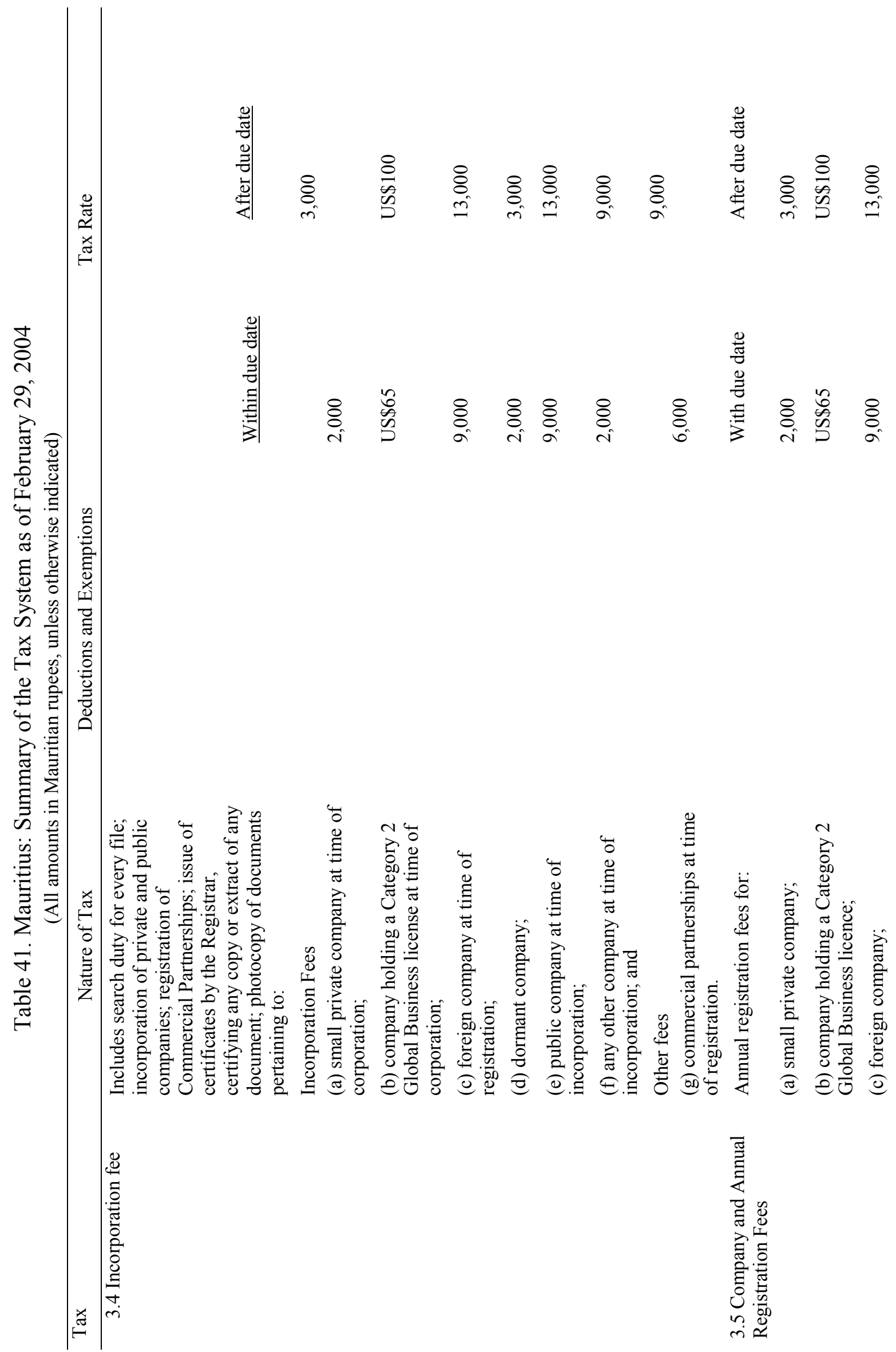




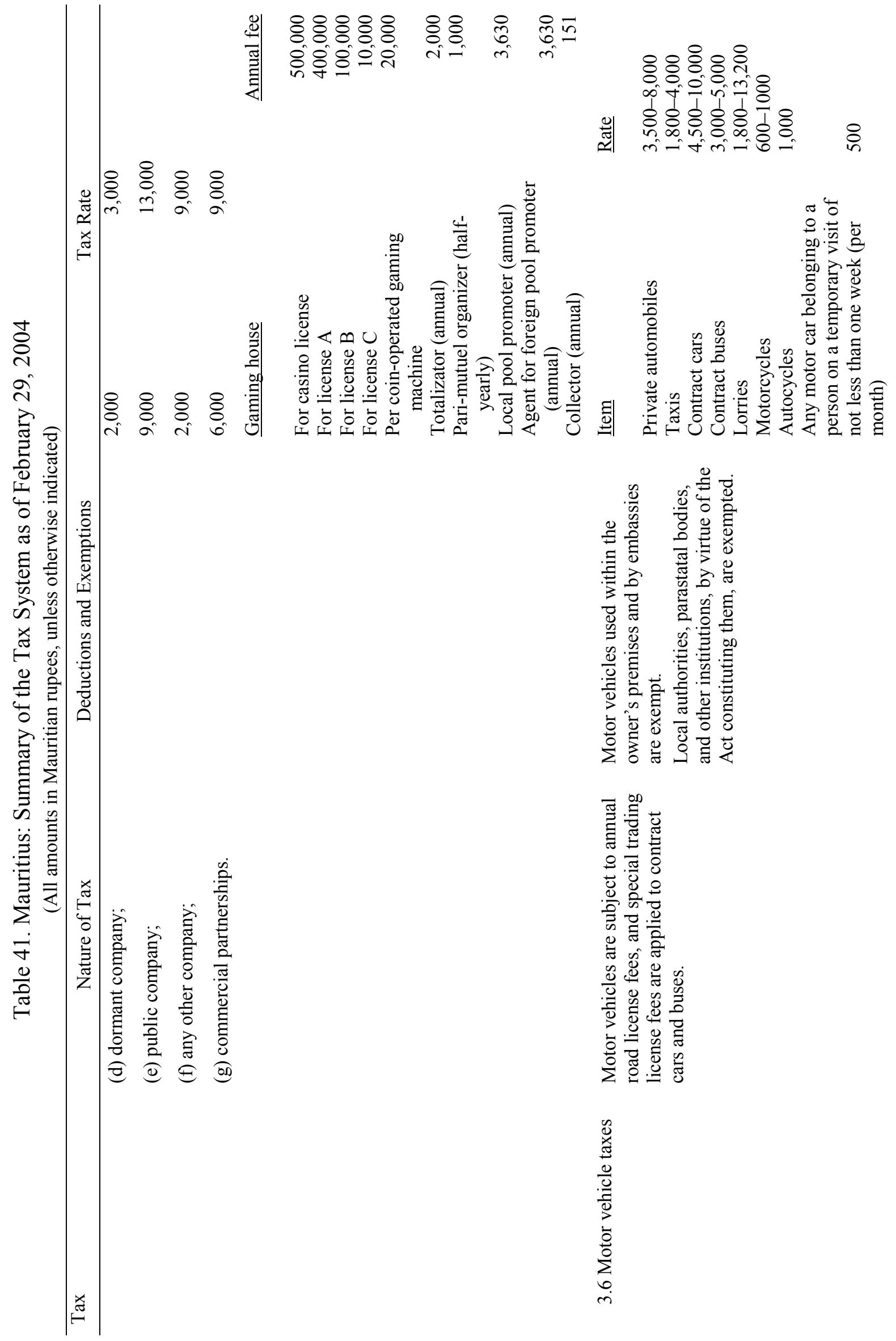




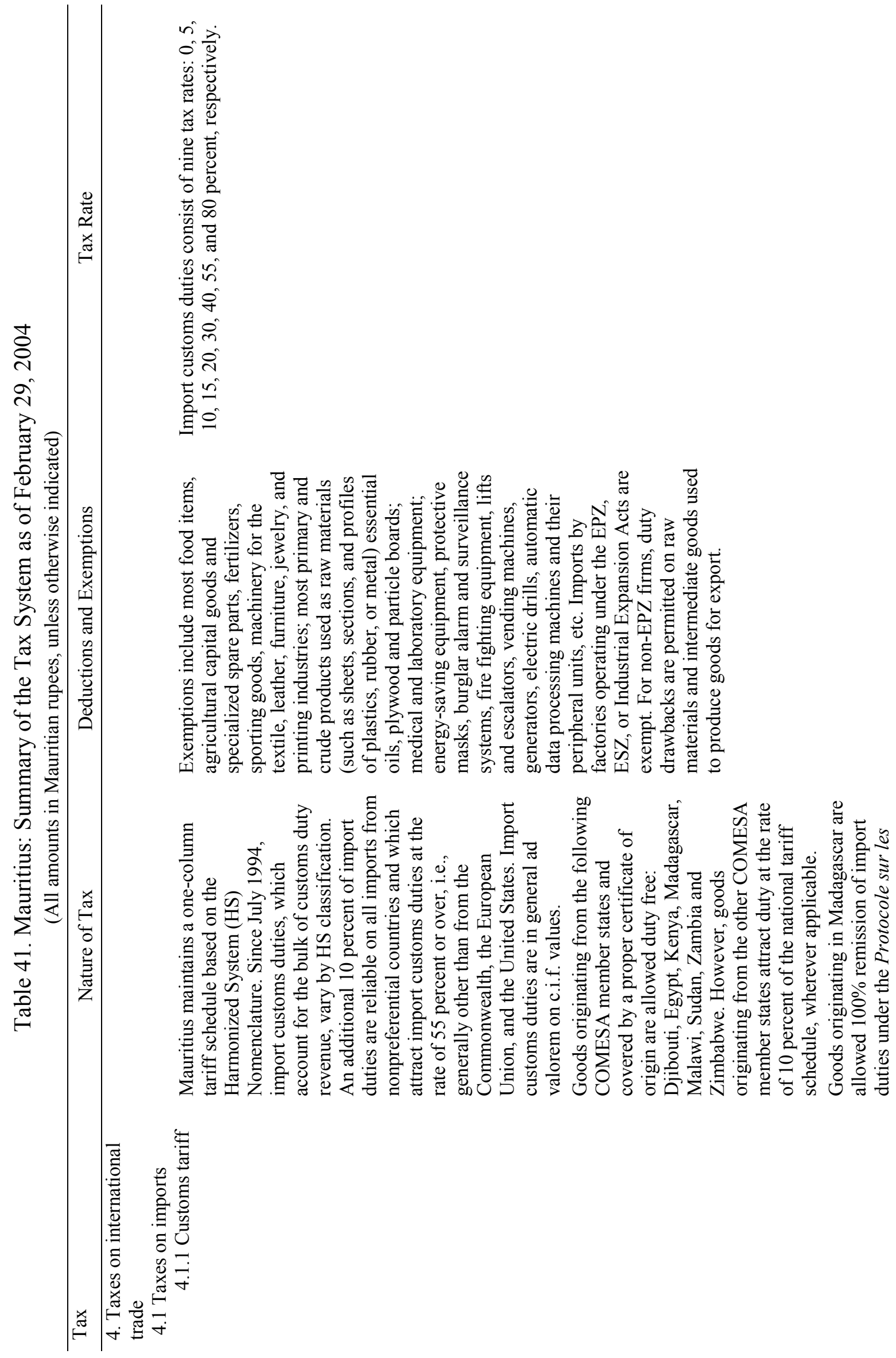



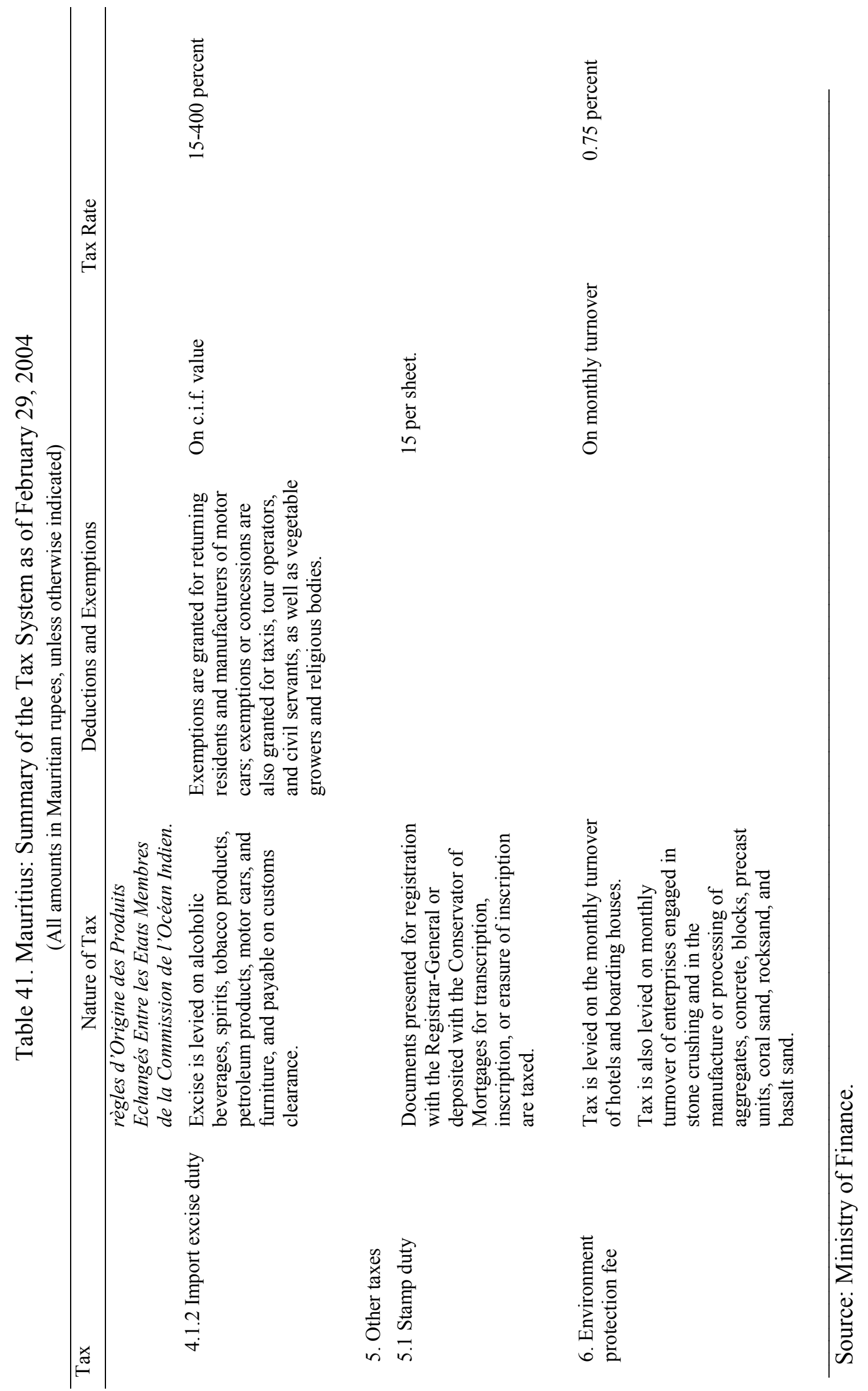